\title{
GEOGRAFIA URBANA
}

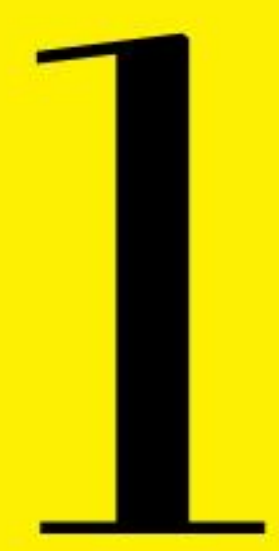

Fabiane dos Santos Toledo

(Organizadora)

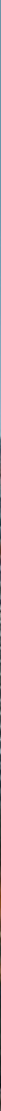


Editora Poisson

\section{Geografia Urbana Volume 1}

1a- Edição

Belo Horizonte

Poisson

2019 
Editor Chefe: Dr. Darly Fernando Andrade

\section{Conselho Editorial}

Dr. Antônio Artur de Souza - Universidade Federal de Minas Gerais

Msc. Davilson Eduardo Andrade

Msc. Fabiane dos Santos Toledo

Dr. José Eduardo Ferreira Lopes - Universidade Federal de Uberlândia

Dr. Otaviano Francisco Neves - Pontifícia Universidade Católica de Minas Gerais

Dr. Luiz Cláudio de Lima - Universidade FUMEC

Dr. Nelson Ferreira Filho - Faculdades Kennedy

Msc. Valdiney Alves de Oliveira - Universidade Federal de Uberlândia

Dados Internacionais de Catalogação na Publicação (CIP) G345

Geografia Urbana - Volume $1 /$

Organização: Fabiane dos Santos Toledo

Belo Horizonte - MG: Poisson,

2019 - 167p

Formato: PDF

ISBN : $978-85-7042-056-5$

DOI : $10.5935 / 978-85-7042-056-5$

Modo de acesso: World Wide Web

Inclui bibliografia

1. Meio ambiente 2. Gestão. I. Toledo, Fabiane dos Santos

O conteúdo dos artigos e seus dados em sua forma, correção e confiabilidade são de responsabilidade exclusiva dos seus respectivos autores.

Baixe outros títulos gratuitamente em www.poisson.com.br

contato@poisson.com.br 


\section{Sumárīio}

Capítulo 1: Metropolização do rural: urbanidades e ruralidades no território de Ravena, MG.

Caroline Cristiane Rocha, Lúcia Karine de Almeida

Capítulo 2: Urbanização e desastre: o processo de reassentamento da população de Bento Rodrigues, Mariana, Minas Gerais. 18

Breno Fonseca de Araujo, Gabriela Mara Batista de Sousa, Paula Pires Santos Pereira Thomaz

Capítulo 3: A criação e efetivação da região metropolitana de Palmas-TO: Critérios e processo de institucionalização 31

Dalva Marçal Mesquita Soares, Celene Cunha Monteiro Antunes Barreira

Capítulo 4: Relações de usos e consumos de espaços públicos de lazer e turismo na cidade de Aracaju/SE. 42

Cristiane Alcântara de Jesus Santos, Larissa Prado Rodrigues

Capítulo 5: Macaé como cidade média pela atração de mobilidades pendulares 57

Célio Fidelis Quintanilha, Felipe Ricardo Branco do Nascimento, Lucas Gomes Maia

Capítulo 6: Arranjos institucionais híbridos e os projetos da copa do mundo Fifa 2014 na região metropolitana do Recife (RMR): Uma abordagem situacional até o ano de 2017 68

José Geraldo Pimentel Neto, Keilha Correia da Silveira, Flavio Antônio Miranda de Souza, Ana Cláudia Rocha Cavalcanti

Capítulo 7: Uma geografia histórica urbana/ regional da província fluminense...

Valter Luiz de Macedo

Capítulo 8: A instrumentalização do estado em favor do mercado na produção do espaço urbano: do planejamento estratégico ao "Modelo Odebrecht" de inserção nas operações urbanas consorciadas, Rio de Janeiro - Salvador. 91

Piero Carapiá Lima Baptista

Capítulo 9: A importância do porto seco para a economia regional contemporânea do Brasil: Anápolis (GO) e Porto Franco (MA) como referências. 104 João Gabriel da Silva Oliveira, Antonio José de Araújo Ferreira 


\section{Sumário}

Capítulo 10: Governança interfederativa na RMVPLN/SP: Um caminho de colaboração dos entes federados

Priscila Maria de Freitas

Capítulo 11: Mobilidade e responsabilidade social: Uma análise sob a perspectiva do desenvolvimento orientado pelo transporte como indutor de equidade e coesão urbana 126

André Luiz Bezerra da Silva

Capítulo 12: As ocupações estudantis no município de Curitiba e segregação urbana: a escola entrando em cena na luta pelo direito à cidade. 139

Anna Paula Scherer Lino, Kauê Avanzi

Capítulo 13: Proyectar desde la esencia del habitante. form follows life. 151 Ignacio Abad Cayuela, Juan Moreno Ortolano

Autores: 


\section{Capítulo 1}

\section{METROPOLIZAÇÃO DO RURAL: URBANIDADES E RURALIDADES NO TERRITÓRIO DE RAVENA, MG}

\section{Caroline Cristiane Rocha}

\section{Lúcia Karine de Almeida}

Resumo: O presente trabalho pretende discutir as identidades urbanas e rurais existentes em Ravena, distrito de Sabará, Minas Gerais, para além dos limites territoriais ou das dicotomias que reduzem a complexidade e especificidades do espaço. Deve-se analisar a totalidade na qual o objeto de estudo está inserido, método que foi pretendido através da pesquisa e da investigação em campo. $O$ estudo de caso foi escolhido devido ao interesse de se compreender qual é a relação do lugar com seus aspectos rurais, intrínsecos em suas relações históricas, além de refletir sobre as consequências da sua atual expansão urbana. Finalmente, considerando a legislação como um agente produtor do espaço, defende-se a necessidade de pensar políticas de planejamento e refletir sobre estratégias de fortalecimento desses espaços.

Palavras-chave: Identidades rurais e urbanas. Limites metropolitanos. Políticas de planejamento.

\footnotetext{
* Trabalho apresentado no XV Simpósio Nacional de Geografia Urbana, 2017
} 


\section{INTRODUÇÃO}

O planejamento urbano existe para que a organização espacial do território seja adequada aos modos de vida das sociedades. Nas cidades contemporâneas, muitas delas planejadas sob os princípios do urbanismo moderno, a forma urbana deve trabalhar para que os quatro pilares desse urbanismo ${ }^{1}$, morar-trabalhar-divertirlocomover, aconteça de forma mais equilibrada. As políticas públicas deveriam visar a melhor qualidade de vida para a população e prever densidades e usos adequados à infraestrutura urbana, promovendo espaços públicos e atendimento a serviços em todo o território. Técnicos, representantes políticos, cidadãos, todos deveriam ser responsáveis pelo espaço em que vivem e participar do planejamento urbano de seus territórios.

O cerne da questão é que o termo planejamento tende a associar-se com adjetivo urbano. Isso quer dizer que tudo o que foi dito anteriormente refere-se ao território cidade, pois as cidades são a expressão máxima do modo de vida urbano. Mas e os outros territórios? A geopolítica atual brasileira determina que o país deve ser dividido em entes federados: distrito federal, estados e municípios, sendo que este último pode ou não ser subdividido em distritos. Nos territórios municipais existem, além das cidades, áreas de menor porte, mas que concentram população, como os pequenos povoados ou vilas, que correspondem ou não às sedes de distritos, e são micro urbanidades ou pequenas centralidades nos grandes espaços rurais. A administração municipal, conforme regras federativas e através de legislações, organiza o seu território em áreas urbanas e rurais,

\footnotetext{
${ }^{1} \mathrm{O}$ urbanismo tem quatro funções principais, que são: primeiramente, assegurar aos homens moradias saudáveis, isto é, locais onde o espaço, o ar puro e o sol, essas três, condições essenciais da natureza, Ihe sejam largamente asseguradas; em segundo lugar, organizar os locais de trabalho, de tal modo que, ao invés de serem uma sujeição penosa, eles retomem seu caráter de atividade humana natural; em terceiro lugar, prever instalações necessárias à boa utilização das horas livres, tornando-as benéficas e fecundas; em quarto lugar, estabelecer o contato entre essas diversas organizações mediante uma rede circulatória que assegure as trocas, respeitando as prerrogativas de cada uma. (IPHAN, Carta de Atenas de 1933, p.29).
}

considerando principalmente as atividades econômicas ali desenvolvidas, a densidade demográfica do lugar e os aspectos ambientais relevantes. Dessa forma surge um questionamento pertinente ao tema deste trabalho: existe algum planejamento territorial que faça a integração entre áreas rurais e urbanas, principalmente nesses territórios em que existe maior interface entre o campo e a cidade? Como a população que não se insere na categoria urbano ${ }^{2}$ é contemplada pelas políticas públicas de planejamento do seu município?

O estudo de territórios que apresentem de alguma forma, seja na identidade coletiva, ou mesmo em políticas de planejamento, interface com o rural, pode trazer à luz uma discussão relevante para o campo da Arquitetura e do Urbanismo, temática essa ainda muito restrita aos estudos de especialistas da área de Geografia. Essa discussão sobre o rural e o urbano deve estar presente na elaboração de planos urbanos/rurais/regionais/metropolitanos que estruturam esses lugares através de instrumentos como os Planos Diretores e as Leis de Uso, Ocupação e Parcelamento do Solo (LUOPS). Isso mostra que o tema, apesar de pouco tratado dentro das escolas de arquitetura, é pertinente para profissionais e estudantes (e claro, cidadãos) que pretendem contribuir para discussões que promovam políticas públicas mais próximas das especificidades dos lugares.

O objeto de análise deste estudo foi escolhido devido ao histórico de evolução da ocupação e os atuais problemas enfrentados pela população. O território de Ravena, distrito do município de Sabará, em Minas Gerais, tem uma relevância histórica devido às origens de sua ocupação, que assim como o distrito sede do município, estão ligadas à época do Ciclo do Ouro em Minas Gerais ${ }^{3}$. Além disso,

2 O Instituto Brasileiro de Geografia e Estatística
(IBGE), órgão responsável pela coleta e
publicação de estatísticas oficiais sobre o território
nacional, lança mão dos termos rural e urbano para
definir a localização domiciliar. Nesse sentido, rural
e urbano são estritamente categorias do que os
documentos oficiais denominam de situação de
domicílio [...] os domicílios são considerados de
situação urbana quando estão em área assim
denominada pela legislação vigente. A população
rural, por seu turno, corresponde ao restante da
população residente em área para além desses
limites. (COSTA; SANTOS; COSTA, 2013. p. 110).
${ }^{3}$ O Ciclo do ouro é considerado o período em que
o Brasil tem como principal atividade econômica a 
existe uma interface metropolitana do distrito, que se encontra diretamente ligada à capital mineira pela Rodovia Federal Fernão Dias BR 381. Observa-se constantes modificações da paisagem entre a capital e o território de estudo, que não é contínua, mas sim uma mistura de ruralidades e urbanidades onde as ocupações acontecem de maneira espraiada e descontínua. Tal processo é verificado devido à estagnação do crescimento de Belo Horizonte e pressão populacional sobre os municípios limítrofes, que crescem e configuram áreas conurbadas, apresentando como característica principal a periferização da pobreza e a ocupação urbana de áreas antes consideradas rurais ou de interesse ambiental.

A discussão sobre as relações entre o rural e o urbano, que se estruturou por muito tempo sobre uma dicotomia e principalmente sobre a ideia de que o urbano seria o rural alterado, uma espécie de evolução onde a cidade seria o último estágio da urbanização, toma forma na contemporaneidade sob a busca de uma compreensão da coexistência desses territórios, e mais, da existência de outros que não podem ser classificados apenas como rurais ou urbanos. O objeto de análise deste trabalho - o distrito de Ravena - pode ser considerado um desses territórios, que a princípio considerado majoritariamente rural pela organização territorial e zoneamentos do município, vem passando por constantes transformações que promovem alterações nas leis de uso e ocupação do solo. Isso mostra que as áreas urbanas não param de crescer e que tal crescimento, não previsto pelo planejamento do município, promove soluções tardias de compensações e mitigações com elevados gastos públicos e impactos para a população.

Assim, uma das questões norteadoras deste trabalho seria compreender quais são as atuais interfaces urbanas e rurais do território, trazendo a discussão sobre as especificidades desses lugares que não são tratadas no planejamento regional. Para isso foi necessário uma pesquisa conceitual, histórica e da legislação em vigor, onde se encontra a definição de áreas urbanas e rurais feitas pelo município, e a legislação proposta, bem como o Plano Diretor de Sabará e o Plano Diretor Metropolitano, na

extração aurífera, principalmente nos estados de Minas Gerais, Goiás e Mato Grosso, e teve seu início no final do séc. XVII. busca da compreensão do território em diversas escalas de planejamento: municipal, regional e metropolitano. Além disso, foram feitas entrevistas ${ }^{4}$ para avaliar a possibilidade de manutenção de traços de ruralidade do território, com o objetivo de descobrir se estes ainda resistiam nas relações sociais e nos modos de vida da população.

Pretende-se aqui não apenas fazer uma reflexão teórica sobre as questões que envolvem o tema, mas apresentar, sob a perspectiva histórica e do planejamento atual, aspectos relevantes que devem ser considerados pelos técnicos e governantes ao planejar ou elaborar políticas públicas que considerem esses territórios ainda não completamente urbanizados. Dessa forma, reflete-se também sobre o papel do arquiteto e urbanista para 0 entendimento das interfaces entre os aspectos físico-ambientais, culturais e econômicos das urbanidades e ruralidades.

\section{IDENTIDADES PARA ALÉM DOS LIMITES TERRITORIAIS}

Antes da abordagem do território porém, fazse necessário a discussão dos conceitos. Afinal, o que é rural? O que é urbano? Empiricamente, pode-se perceber que ambos os espaços são distintos em suas formas e processos socioculturais. Roberto Luís MonteMór (2005) irá tratar da dicotomia cidadecampo, onde o campo seria um espaço natural circundante a alguma centralidade urbana, na qual ele dependeria e desempenharia o papel de um território complementar. O conceito urbano estaria se referenciando a tudo o que é próprio da cidade, centro político e mercantil, e o rural seria tudo que é próprio do campo, a produtividade. Entretanto, com a chegada da produtividade na cidade - industrialização aumenta a subordinação do campo e rapidamente a cidade se torna o locus, meio urbano capitalista, privilegiado da reprodução coletiva da força de trabalho. (MONTE-MÓR, 2005). Nesse momento, como destaca o autor, o tecido urbano-industrial se estenderia para além das cidades, sobre o campo:

Em pouco tempo, essa extensão das relações de produção capitalistas e das condições

\footnotetext{
4 Foi necessário um recorte espacial para a aplicação das entrevistas, devido à dimensão territorial do distrito, escolhido por ser a centralidade histórica e simbólica de Ravena.
} 
gerais de produção (e de reprodução da força de trabalho) atingiu virtualmente todo o espaço nacional. Essa percepção de um futuro dominado pelo tecido urbano-industrial [...]. O que parecia não mais existir, virtualmente, eram os problemas rurais ligados à rusticidade, ao isolamento, à desarticulação e exclusão do campo face ao mundo moderno. Virtualmente, o meio rural estaria, ao final da década de 1970, também integrado ao meio urbano-industrial no Brasil. (MONTE-MÓR, 2005. p.15).

Essa integração do rural ao meio urbanoindustrial, em que o rural perde o seu caráter de isolamento, é chamada pelo autor de urbanização extensiva, a extensão da práxis urbana, que nasce nas grandes cidades e que "transborda sobre seu espaço imediato, mas se estende (virtualmente) pelo espaço regional e nacional como um todo, todo ele cortado e integrado a essa centralidade urbano industrial". (MONTE-MÓR, 2005. p.16). $\mathrm{Se}$ em um primeiro momento isso ocorreu através da industrialização (no caso do município de Sabará, principalmente através da atividade minerária), percebe-se que agora isso acontece pelos meios informacionais: computadores, celulares, televisores.

Essa extensão do modo de vida urbano a todo o espaço social e humano acontece devido ao poder cultural e social da cidade em relação ao campo que, segundo o geógrafo João Rua (2010), se reflete na representação do espaço.

Esse poder, centrado na cidade moderna capitalista, vem impondo símbolos, códigos e signos territorializados tanto ao "rural" quanto ao "urbano", que têm, como vimos, seus papéis alterados pelos atores produtores dessas espacialidades redefinindo suas identidades em cada momento do movimento do todo social. (RUA, 2010, p.45).

É o poder centrado na cidade moderna capitalista que introduz ao espaço rural modo de viver, pensar e agir urbano. Entretanto, Monte-Mór coloca ainda que existem "ilhas de ruralidades", os seja, locais onde a urbanização ou "as forças modernizadoras do capitalismo industrial" não modificou completamente o espaço e ainda existem processos socioespaciais de organização da vida cotidiana e da produção que respondem a dinâmicas de um meio rural. (MONTE-MÓR, 2005). Nesse aspecto, Rua coloca a importância da escala de análise pois, se olharmos de forma mais ampla, veremos um território onde 0 urbano se manifesta ideologicamente e comportamentalmente, com representações homogeneizadoras dos espaços. No entanto, um recorte geográfico menor ou mais específico, revela que existem interações urbano-rurais "em que espaços híbridos serão gerados como frutos particulares de tais interações." (RUA, 2010, p.46).

Rua irá abordar o conceito de espaços ainda não classificados e territorialidades que ainda estão por definir, devido às possíveis múltiplas interações entre o rural e urbano. Além dessas interações, o autor coloca a importância da compreensão do espaço territorializado, ou seja, socialmente construído e lugar de relações, apropriações e dominações. (RUA, 2010). Isso se torna extremamente relevante quando se pretende compreender as relações da população com - local, principalmente em espaços metropolizados, como é o caso da Região Metropolitana de Belo Horizonte ${ }^{5}$, onde características e problemas antes exclusivos do meio urbano, vão se reproduzir nos espaços rurais.

Além disso, o autor refere-se a espaços híbridos nos quais urbano e rural integram-se, o que é chamado por ele de "urbanidades no rural". Em um primeiro momento pode-se compreender que isso seria uma oposição às "ilhas de ruralidades" de Monte-Mór. Entretanto, em espaços tão complexos onde o urbano e o rural encontram-se em uma única espacialidade, esbarrando em questões culturais, históricas e de desenvolvimento econômico, é necessário considerar ambos pontos de vista, na expectativa de compreender como o território se apresenta: em uma série de "mistos", como coloca Rua, em que "o rural não é (mais) plenamente rural porque incorpora 'urbanidades' que com ele vão interagir e dar lugar a territorialidades outras, que resta por definir." (RUA, 2010, p.50); ou em espaços em que as relações sociais no espaço expressam ruralidades únicas, onde população e território possuem características relevantes e que devem ser fomentadas pelo planejamento.

\footnotetext{
5 A Região Metropolitana de Belo Horizonte $(\mathrm{RMBH})$ é uma subdivisão administrativa do estado de Minas Gerais composta por 34 municípios, dentre eles o município de Sabará. (MINAS GERAIS, 2011).
} 
Assim temos uma abordagem que foge da visão homogeneizadora em que cidade e campo se verão fundidos numa única espacialidade "urbanizada", permanecendo essa dicotomia dos espaços periféricos/rurais e centrais/urbanos. Hespanhol (2013) coloca que a consolidação das relações de proximidade entre espaços rurais e urbanos está associada às condições de acesso à infraestrutura (viária principalmente) e serviços à população rural que garantam a cidadania e a autonomia. As pessoas que vivem no campo hoje mantêm estreitas relações e vínculos com as cidades e o modo de vida urbano. Também Talaska, Silveira e Etges (2014) irão abordar esses vínculos, colocando que na contemporaneidade, existe um processo de complexização do modo de organização socioespacial, o que dificulta a definição de urbano e rural. Esses autores consideram a superposição das formas urbanas e rurais, através de um continuum espacial (conceito de Robert Redfiel, 1930), partes de uma mesma totalidade, onde não se pressupõe o desaparecimento do campo e sim a constituição de áreas de transição, onde mesmo com a aproximação entre rural e o urbano, não desaparecem suas particularidades. (TALASKA, SILVEIRA, ETGES, 2014).

Não se trata também de enxergar o rural apenas como um conjunto de bens simbólicos e de práticas culturais a serem consumidos pela sociedade urbanocapitalista, que deseja uma relação com a natureza e fuga do centro caótico. Se trata porém, de enfatizar a diferença dos territórios e que cada um tem sua própria história, que se materializa em espacialidades/territorialidades próprias. Rural e urbano integram-se, mas sem se tornarem a mesma coisa (coexistência), já que preservam suas especificidades (multiplicidade). $\mathrm{O}$ rural incorpora "urbanidades" que com ele vão interagir e dar lugar a territorialidades outras. (RUA, 2010). Essa abordagem nos interessa pois coloca que a ideia de urbanização rural dificulta a compreensão dos processos em curso, como o caráter híbrido das identidades territoriais construídas e as múltiplas dimensões das relações sociais. Para compreender essas relações sociais geradoras de território, é necessário também compreender a identidade territorial dos habitantes, a dimensão simbólica-cultural daquele lugar, para os que ali vivem.

\section{O LUGAR DO LOCAL NO METROPOLITANO}

Para tratar dos conceitos urbano e rural em uma abordagem concreta, analisando um território, é necessário compreender as interfaces da divisão territorial administrativa. Os limites administrativos se configuram como grandes influenciadores nas decisões de planejamento e gestão, pois esses são potenciais ou limitadores do desenvolvimento dos territórios. Os estados brasileiros são divididos em municípios, que podem ou não ser divididos em distritos, os quais podem apresentar apenas perímetros urbanos ou perímetros urbanos e rurais. A cidade é o perímetro urbano mais desenvolvido de um município, os outros perímetros urbanos são chamados de povoados e sedes de distritos. Para que ocorra a ligação entre as diversas regiões do território, deve-se prever uma rede urbana bem articulada, não só referente à infraestrutura, mas também à oferta de bens e serviços.

Dessa forma, ao compreender a criação de regiões metropolitanas como uma grande expressão dessas redes, em escala intermunicipal, torna-se necessário questionar qual o lugar do local, daquilo que é específico e característico do território. A possibilidade de entender sua relevância metropolitana sem deixar de olhar para a suas origens e possíveis ruralidades pode abrir portas para políticas públicas com foco nas identidades do lugar. 
Figura 1: Inserção do município de Sabará na Região Metropolitana de Minas Gerais.

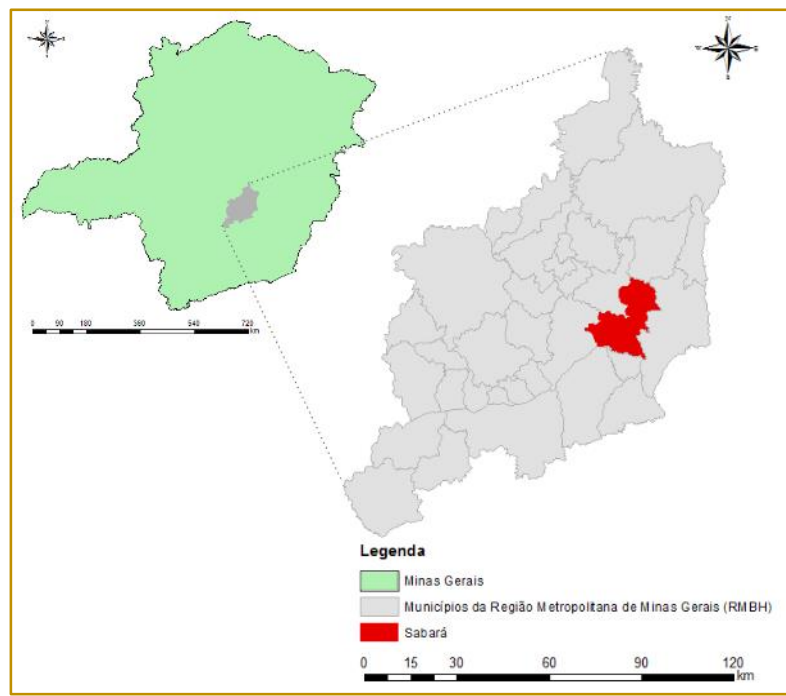

Fonte: Elaborado pela autora com dados do IBGE, 2017.

\subsection{ORIGEM DE RAVENA: GEOGRAFIAS E HISTÓRIAS}

O objeto de análise deste trabalho é o distrito de Ravena, um dos quatro distritos pertencentes ao município de Sabará, composto também pelos territórios de Carvalho de Brito e Mestre Caetano, além do distrito sede - figura 2. Sabará insere-se na Região Metropolitana de Belo Horizonte $(\mathrm{RMBH})$, que configura-se como uma divisão administrativa do estado de Minas Gerais. A contextualização metropolitana é relevante para o estudo, já que verifica-se atualmente vários processos de conturbação e impactos dessa expansão desordenada da mancha urbana a partir da centralidade de Belo Horizonte (MINAS GERAIS, 2011).

Sabará é um município limítrofe à metrópole, portanto a dependência de seus habitantes com a capital é grande, que ocorre até mesmo em detrimento à cidade de Sabará. O distrito de Ravena tem um acesso direto a Belo Horizonte através da BR-381. O percurso Belo Horizonte-Ravena, que leva aproximadamente 35 minutos, desconsiderando os constantes congestionamentos ocorrentes na rodovia, mostra como o território se modifica e se transforma em uma mistura de redes de urbanidades e ruralidades.

Figura 2 - Distritos do município de Sabará com principais eixos viários.

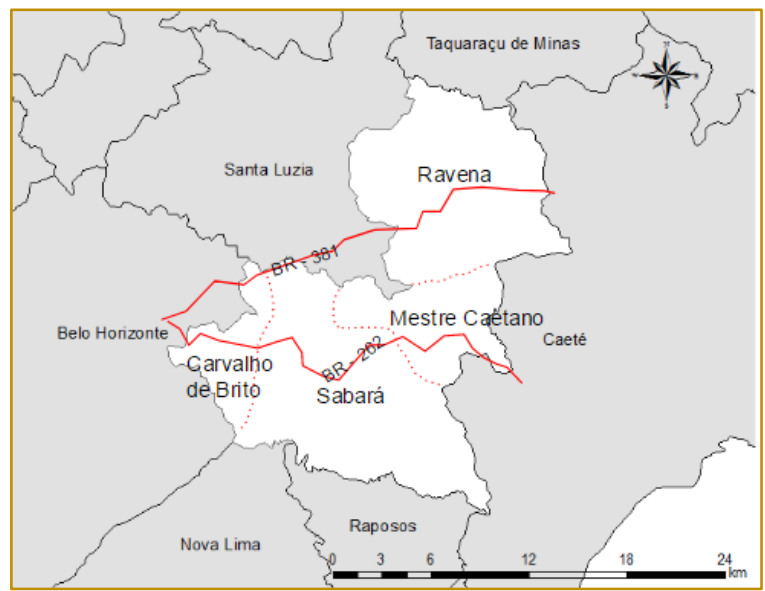

Fonte: Elaborado pela autora com dados do IBGE, 2017. 
Essa rede é perceptível pela mudança da paisagem - figura 3 -, apesar da curta distância no trajeto realizado em via de ligação interestadual (BR-381) que cumpre papel de via urbana em vários municípios da $\mathrm{RMBH}$. Percebe-se que as ocupações limítrofes de Belo Horizonte (no caso estudado, na regional nordeste, altura do bairro Jardim Vitória) é extremamente precária (1). Vilas e favelas ocupam a faixa de domínio da rodovia e outros resquícios da histórica ocupação periférica da capital mineira quanto mais afastado do centro, mais barata é a moradia. Por outro lado, aparecem pelo caminho empreendimentos habitacionais que reforçam a dependência do centro ao implantar moradias em locais isolados, como é o caso do condomínio Parque Real, no bairro Capitão Eduardo - Belo Horizonte (2). Ambas as situações mostram a pressão imobiliária, principalmente de famílias de baixa renda e a expansão metropolitana, a cidade em direção ao ambiente mais ruralizado. Já em Sabará, neste mesmo trajeto da mobilidade diária metropolitana, e logo após a ponte sobre o Rio das Velhas (3) - um dos limites entre os municípios -, é nítida a transformação sequencial da paisagem, de pequenos bairros, ainda pouco adensados e próximos à rodovia, a sítios isolados e depois vastos campos de agropecuária, agricultura típica da região (bananeira) e mata natural preservada por legislação (Serra da Piedade (4)). Por fim chega-se no distrito, que se desenvolveu ocupando o território rural de Sabará.

Figura 3 - Percurso Belo Horizonte-Ravena: foto de satélite revela núcleos urbanos espraiados.

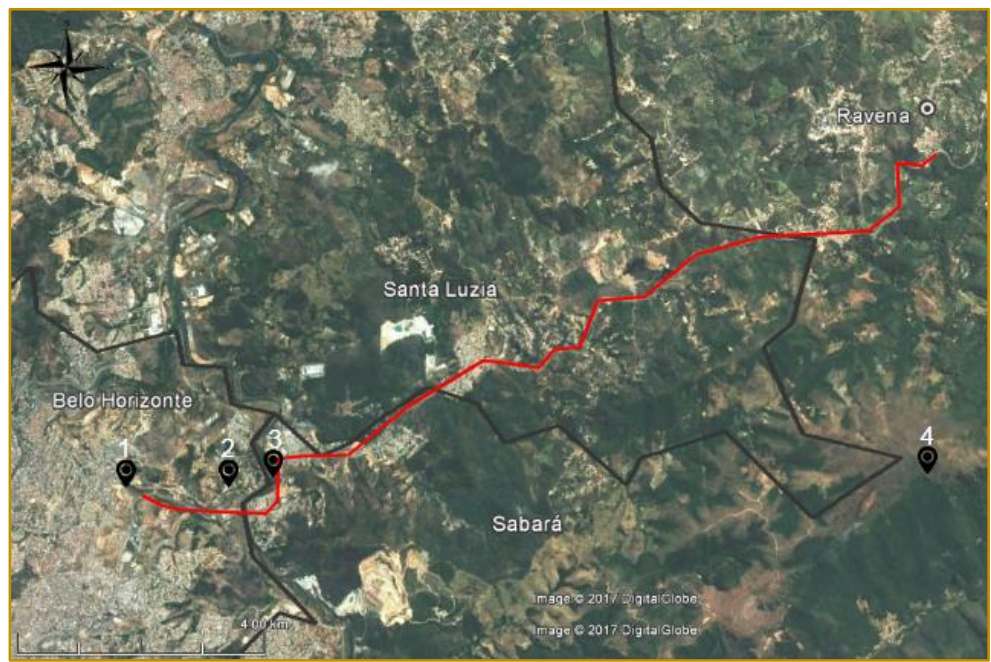

Fonte: Elaborado pela autora sobre base do Google Earth, 2017. Obs.: numeração de acordo com os aspectos citados no texto

As origens do município de Sabará são registradas na época do Ciclo do Ouro em Minas Gerais e a sede do município tem em seu traçado aspectos remanescentes de sua ocupação inicial, a partir do final do século XVII. Salomão Vasconcellos (1945) relaciona a formação do primeiro núcleo urbano no território a grupos vindos de várias partes do Brasil em busca do ouro descoberto em Ouro Preto e que se dirigiram para Sabará, Caeté, Itabira do Campo, Santa Bárbara, e outros locais próximos. Entre 1701 e 1703, a população de Sabará era de "quase todos baianos, paulistas, pernambucanos e portugueses". (VASCONCELLOS, 1945).

Assim como o distrito sede, Ravena surgiu em inícios do século XVIII em decorrência da exploração de ouro nos arredores. Segundo o Instituto Estadual do Patrimônio Histórico e Artístico de Minas Gerais (IEPHA/MG), o antigo povoado denominado Lapa "provavelmente, contava com razoável número de habitantes pois, um documento de 1727 comprova que a capela local se encontrava em atividade regular, com capelão designado." (MINAS GERAIS, 2014, p.75).

Devido a época de seu surgimento, o distrito apresenta construções do período colonial mineiro que tem valor simbólico e cultural para o município e para o estado. O conjunto arquitetônico e paisagístico da Igreja de Nossa Senhora da Assunção da Lapa, construída de pedra e madeira com 
provimentos da exploração aurífera e os

pelo IEPHA/MG em 1977 - figura 4.

engenhos de cana de açúcar, foi tombado

Figura 4 - Distrito de Ravena à esquerda e Adro da Igreja Nossa Senhora da Assunção da Lapa à direita. Data desconhecida.

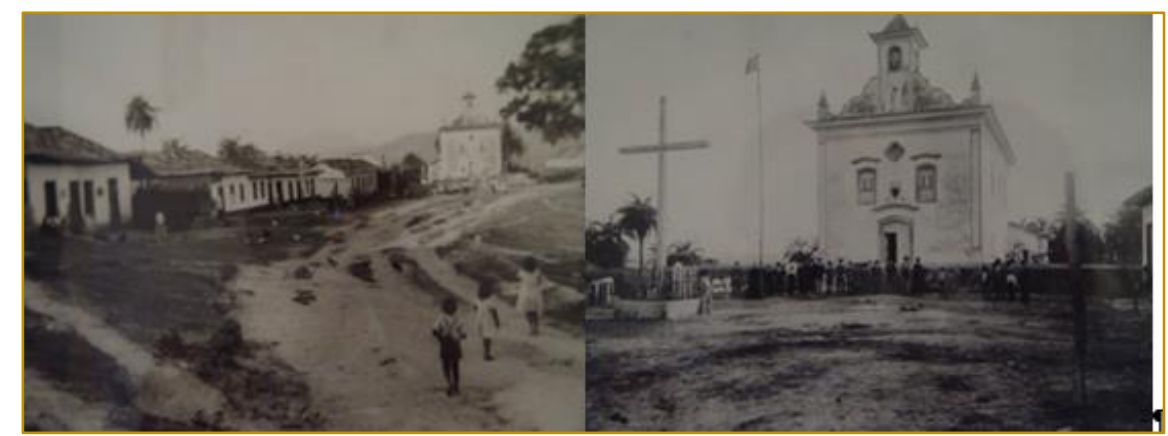

Fonte: (MEMÓRIA...,2017)

O nome do distrito vem de uma homenagem ao frei italiano Luís de Ravena, responsável por uma das principais reformas da igreja matriz em 1853. (MINAS GERAIS, 2014).
Muito do traçado urbano original desse núcleo urbano, que configura-se de maneira orgânica, pode ainda ser percebido - figura 5.

Figura 5 - Vista do núcleo urbano de Ravena.

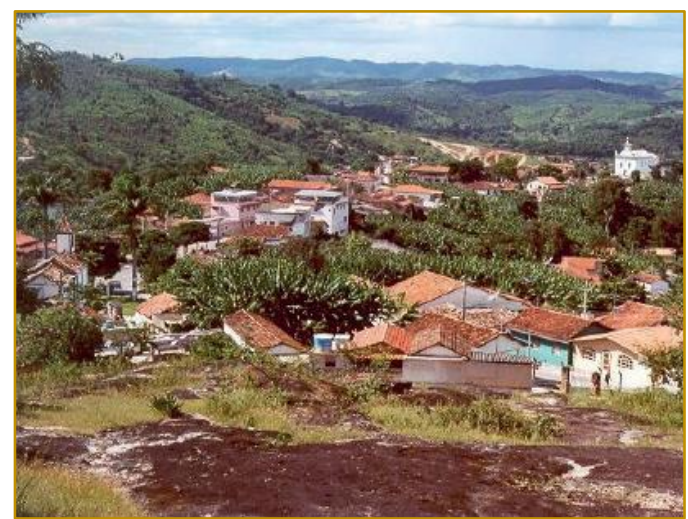

Fonte: Acervo do IEPHA/MG, p. 76.

Sobre a relevância histórica do distrito, o IEPHA destaca:

- distrito guarda da época colonial, a fisionomia urbana, com uma única rua que se desenvolve na cumeada do morro e se alarga em extensa praça no entorno da Matriz. Ao esgotarem as jazidas locais, esse primitivo núcleo minerador entrou em decadência e passou a desenvolver atividades agrícolas. No núcleo urbano, a maioria do casario primitivo arruinou-se, restaram apenas alguns exemplares, uns em péssimas condições e outros poucos mantidos apenas pela ação dos proprietários. (Minas Gerais, 2014, 75).

\subsection{NOVAS URBANIDADES E VELHAS RURALIDADES}

O levantamento de informações em campo mostra-se imprescindível quando se trata de planejamento, pois o diagnóstico do local é de extrema importância para que as propostas levantadas sejam adequadas aos aspectos físicos-ambientais, culturais e históricos dos locais de intervenção. Além disso, torna-se fundamental o papel dos planejadores para $\mathrm{o}$ entendimento $\mathrm{e}$ promoção das interfaces entre demandas sociais e interesses públicos. Dessa forma, o reconhecimento dos anseios e desejos da 
população constituem importantes eixos norteadores da pesquisa empírica qualitativa adotada neste trabalho.

A visita à campo ${ }^{6}$ teve o objetivo de avaliar a possibilidade de manutenção de traços de ruralidades no território, principalmente através da cultura, história e dos modos de vida da população. O público alvo foram pessoas que morassem em Ravena, a sede do distrito. O recorte espacial, necessário ao tamanho do território, foi escolhido pelo visível papel de centralidade, além do seu caráter histórico e simbólico (Rua Sabará, Rua Arco da Lapa e Rua Benedito Saturnino da Rocha). Para metodologia de abordagem foram selecionados tópicos sobre o universo pessoal do indivíduo (história, memórias) e depois sobre o contexto geral de vida na comunidade (local de vivência, relação direta com o território). As primeiras perguntas envolviam laços históricos-familiares com o lugar e o motivo de residência. As discussões seguintes envolviam o entrevistado na sua identidade territorial, ao buscar compreender se a comunidade se identifica mais com o rural ou com o urbano e se apresenta algum tipo de relação com os outros territórios limítrofes, principalmente Belo Horizonte e a cidade de Sabará. Para completar a pesquisa qualitativa, também foram realizadas conversas sobre a relação da comunidade com os rios e córregos (patrimônio ambiental), patrimônio cultural e edificações tombadas. Além disso, foi importante também captar o grau de satisfação do entrevistado com a realidade da qualidade de vida urbana em relação aos temas da pesquisa, bem como angústias e demandas.

A partir da análise dos resultados foi possível perceber que os laços familiares são mantidos no distrito e para manutenção destes a relação com a comunidade e o senso de pertencimento ${ }^{7}$ são fundamentais. A

\footnotetext{
6 Visita de campo realizada no dia 15 de abril de 2017. O método aplicado no trabalho focou em uma pesquisa qualitativa e não quantitativa, buscando entrevistar moradores de destaque na comunidade pelo papel social e memória local. O número de entrevistados poderá ser ampliado para aferir melhores resultados em estudos futuros.

7 Segundo os entrevistados Márcia e Higno, o motivo pelo qual eles moram em Ravena é porque "é um lugar tranquilo e todo mundo conhece todo mundo". Seu Geraldo, de 97 anos, disse que todos (família e comunidade) o ajudam a resolver questões que devido a idade ele não consegue mais.
}

entrevistada $1^{8}$ contou que quando chegou em Ravena ainda não havia asfalto, luz, água e que trabalhava no correio. Ela e o marido, que fora vereador, participaram ativamente pela instalação de energia elétrica no distrito, em 1968. Como lideranças, o casal também lutou pela configuração da Regional Administrativa Ravena, implantação do Posto de Saúde, pela ampliação da escola de ensino fundamental e da construção da escola de ensino médio. Também grande parte dos entrevistados compreendem que o lugar possui fortes características urbanas, como o movimento do comércio nas ruas, a quantidade de carros, etc., mas que alguns aspectos rurais permanecem. Alguns relacionam esses aspectos rurais a proximidade com a natureza. ${ }^{9}$ Nesse sentido, foi questionado o papel dos elementos naturais da paisagem como presença de rios ou córregos na região. Alguns disseram que a água é poluída. ${ }^{10} \mathrm{O}$ entrevistado $2^{11}$ apontou que considera o lugar ainda rural, devido ao contexto paisagístico no qual está inserido, mas entende que os processos de urbanização transformaram Ravena em um espaço urbano. Quando questionado sobre a proposta do novo zoneamento do município de Sabará, onde todo o território de Ravena aparece como única zona urbana, ele disse que acredita que não dará certo devido a desorganização municipal. Segundo ele, antigamente a igreja católica possuía muitos terrenos e quando houve a venda desses terrenos as pessoas não receberam toda a documentação necessária, ou seja, o distrito tem muitos terrenos irregulares.

\footnotetext{
${ }^{8}$ Maria das Dores Ferreira Pinto, 91 anos, mora em Ravena há 70 anos e toda a família é do lugar.

9 Segundo a entrevistada Márcia, ela considera Ravena um território rural "por causa dos pássaros, da mata no fundo do quintal, das galinhas e do córrego que passa pertinho."

10 Meire Mariangela, 58 anos, relatou que costumava lavar roupa no córrego, mas que hoje em dia a água é muito poluída. Álvaro Martim Ribeiro, 72 anos, apontou que os rios e córregos não são tratados, que é despejado esgoto no Rio vermelho e a COPASA (Companhia de Saneamento de Minas Gerais), que seria responsável pelo tratamento desse esgoto, não o faz.

${ }^{11}$ Álvaro foi o primeiro administrador da regional de Ravena, onde nasceu e hoje, mora em Belo Horizonte. No entanto, mantém vínculos com o lugar devido a sua família que permanece em Ravena e por ser presidente do time de futebol e da banda de música do distrito - Sociedade Musical Lira da Paz.
} 
Uma questão relevante a se ressaltar foi o entendimento de Ravena como município pela maioria dos entrevistados, o que por um lado demonstra o grau de importância que os moradores dão ao distrito - ao fator isolamento geográfico em relação à sede municipal e ao papel de centralidade regional metropolitana -, mas que por outro revela o baixo conhecimento geopolítico da população, o que gera uma dificuldade de cobrança frente aos administradores públicos. Esse contexto é agravado pela falta de vínculo da população com Sabará que costuma frequentar a cidade para resolver questões burocráticas relacionadas à prefeitura ou para eventos ocasionais. Vínculo esse que é suprido pela proximidade da capital mineira, já que esta oferece mais opções de lazer e diversidade de comércio com mercadorias de menor custo. ${ }^{12}$

Alguns dos entrevistados relacionam o atual crescimento da mancha urbana e populacional de Ravena ao número de pessoas de Belo Horizonte que está migrando para o distrito, em busca de menor custo de vida. Entretanto muitas vezes essa opção está relacionada a precárias condições de urbanização, já que localidades no interior do distrito possuem dificuldades de acesso a serviços públicos de saneamento, iluminação e transporte, 0 que demonstra 0 desenvolvimento desigual da centralidade do mesmo.

Outro problema recorrente ressaltado pelos moradores é a falta de policiamento e a falta de segurança. Além da necessidade de mais investimentos na saúde ${ }^{13}$ e na educação, alguns pontuaram os chacreamentos irregulares e o crescimento desordenado como problemas graves. O tema patrimônio cultural também foi destacado pelos entrevistados, já que falta incentivo público para preservação do casario antigo e de valor simbólico, como a própria Igreja Matriz que está com o processo de restauro paralisado. $\mathrm{O}$ entrevistado $3^{14}$ conta que a Igreja Nossa Senhora do Rosário possuía capelas laterais,

\footnotetext{
12 Marcia e Higno ressaltaram que a ligação viária Ravena-Belo Horizonte é muito ruim e que os congestionamentos diários são comuns, mas que acreditam que a duplicação da BR-381poderia minimizar esse transtorno na mobilidade.

13 Segundo Álvaro, o distrito possui apenas um posto de saúde com um médico geral. Isso para ele é inadmissível, porque "tem 12 mil habitantes em Ravena. Isso aqui é uma cidade!".

${ }^{14}$ Geraldo, 97 anos.
}

que foram demolidas devido a processos de deterioração pela ação do tempo e descuido por parte das autoridades responsáveis. Ao falar sobre a importância do patrimônio cultural para o distrito, o entrevistado 2 relatou a relevância dos marcos históricos, definidores da ocupação do lugar, como as casas coloniais, da época do ouro, que se perderam no tempo.

Dessa forma, nota-se que os traços de ruralidade que remontam às origens da ocupação do território são relevantes para a população, principalmente os relacionados aos laços históricos e familiares. Os atuais moradores de Ravena, não se reconhecem como há 20, 30 anos atrás, muito em decorrência da expansão da mancha urbana, através de chacreamentos e ocupações irregulares que fragmentam o tecido urbano em contínuo e desordenado processo de transformação. Entretanto, ainda se conservam certos hábitos rurais, como a conversa na porta de casa ou produção agrícola local para comercialização de produtos típicos da culinária rural como queijo, cachaça, linguiça, além da manutenção de festejos tradicionais locais como a cavalgada, festa de santos e festa da banana.

\section{LIMITES, ZONEAMENTOS E TERRITÓRIOS DE SOCIABILIDADES}

O Plano Diretor de Desenvolvimento Integrado (PDDI) está sendo desenvolvido com o objetivo de definir um macrozoneamento da $\mathrm{RMBH}$, para promoção de um planejamento municipal integrado e que possibilite a manutenção de interfaces metropolitanas regionais comuns. Ele deverá estabelecer as diretrizes para o uso e ocupação dessas áreas através de parâmetros que poderão se transformar em legislação ${ }^{15}$. O propósito último, de maneira geral, é incentivar o desenvolvimento de novas centralidades na $\mathrm{RMBH}$ para diminuir a dependência da centralidade belorizontina, suprir necessidades da população sem grandes deslocamentos e promover identidades regionais. Centralidade é entendida como uma área urbana acessível com concentração

\footnotetext{
${ }^{15}$ A elaboração do PDDI da Região Metropolitana de Belo Horizonte se iniciou em 2009 e atualmente há um projeto de lei na assembleia legislativa para a aprovação da legislação referente ao macrozoneamento urbanístico, fruto desse trabalho. Maiores detalhes em: www.rmbh.org.br/pddi.
} 
diversificada de emprego, comércio, serviços públicos e privados, habitação e equipamentos de cultura e lazer. (PDDI, 2013). Uma centralidade deve estar conectada a uma rede urbana de qualidade, que facilite a interface do local com as diferentes escalas - regional, municipal, metropolitana. Como já discorrido anteriormente, Ravena se insere na $\mathrm{RMBH}$ e é considerada centralidade, segundo o PDDI, e por isso a análise dessa macro escala também é relevante. Se o rural sempre se colocou como periferia, ou para além do centro tradicional, agora com essa proposta, todo o território do distrito seria promovido como grande centralidade do vetor leste da $\mathrm{RMBH}$. Esse estudo de caso emerge como exemplo da importância da discussão das novas perspectivas para o urbano e rural na $\mathrm{RMBH}$. Se hoje os espaços são um misto de cidade e campo, como diria Monte-Mór, eles sofrem com a "emergência e extensão do tecido urbano enquanto continente de uma práxis social" (MONTE-MÓR, 2005, p.19), e estariam submetidos a essa interface metropolitana, já que além do território, existe também as relações sociais ditadas pelo modo de vida urbana.

Pelo diagnóstico realizado pelo PDDI, Ravena é classificada como sub-centro metropolitano, o que o categorizou na mancha de macrozoneamento metropolitano como Zona de Interesse Metropolitano (ZIM) de eixo estruturante, que se relaciona com a mobilidade devido a presença da BR-381 e a intenção de ampliação futura da via através da proposta do Rodoanel metropolitano. Ravena também faz parte da Trama Verde e Azul, macrozoneamento pensando em promover a conectividade entre áreas ambientalmente importantes (Serra da Piedade, no caso), e busca assegurar a proteção de mananciais para o abastecimento de água, fundos de vale e de matas ciliares. Por tais aspectos, Ravena foi também demarcado como Área de Interesse Metropolitano (AIM) de complexos ambientais e culturais, cujo objetivo é delimitar projetos de relevância metropolitana que envolvam temas como cultura, turismo, lazer e meio ambiente.

Essas definições em escala metropolitana são importantes para o desenvolvimento da região, entretanto é necessário questionar se a criação de um macrozoneamento e o conceito de centralidade podem assegurar resquícios de ruralidade que ainda existem no território. É preciso avaliar quais são os pontos positivos e negativos da pressão do aumento de ocupação urbana existente e promovida, principalmente, do transbordamento de assentamentos precários de Belo Horizonte (PDDI, 2013), que reforça a dicotomia centro e periferia. A legislação municipal deve ser pensada de maneira a integrar as três camadas constituintes do território: infraestrutura, mesoestrutura e superestrutura $^{16}$. (CARVALHO, 1999). Esse aumento populacional, se não pensado dessa forma, poderá acarretar em os possíveis conflitos com o patrimônio histórico e ambiental, além de afetar o sistema de rede (mobilidade) já saturado. Assim, corre-se o risco de lugares rurais repetirem os mesmos problemas das cidades já consolidadas e os traços culturais que deram origem às primeiras ocupações se perderem nas novas urbanidades. Torna-se necessária a integração entre políticas de planejamento regional metropolitana com as políticas locais, de governo municipal, que ainda enfrentam sérios problemas para serem implementadas na $\mathrm{RMBH}$, principalmente relacionadas à fiscalização da gestão desses territórios e cumprimento de demandas vinculadas às especificidades, como preservação do patrimônio cultural e ambiental.

\section{CONSIDERAÇÕES FINAIS}

Esse artigo destacou a importância da discussão sobre as transformações nos territórios na contemporaneidade no campo da arquitetura e urbanismo, mas é fato que a temática é multidisciplinar e que o papel do técnico é estabelecer canais de discussão entre população e governo. Dessa forma, deseja-se apontar reflexões para futuras contribuições de arquitetos urbanistas e demais profissionais para a manutenção dessas ruralidades e articulação desses espaços a processos mais contextualizados

\footnotetext{
${ }^{16} \mathrm{O}$ termo infraestrutura refere-se aqui a tudo que diz respeito à plataforma natural do território: relevo, vegetação, hidrografia, solo, etc. O termo mesoestrutura refere-se a tudo que diz respeito aos sistemas que possibilitam a ocupação do território: malha urbana, sistema de drenagem, esgotamento, rede de água, luz, etc. Já o termo superestrutura diz respeito a todas as edificações construídas e ao modo de vida das sociedades. Esses conceitos são adotados pelo geólogo Edézio Teixeira de Carvalho (1999), que coloca a cidade como a sobreposição de três camadas: infraestrutura, mesoestrutura e superestrutura.
} 
de urbanização, que promovam a interface das três camadas de território.

Ao considerar a infraestrutura como elemento primordial à manutenção da paisagem desses lugares, é necessário prever em lei áreas de preservação ambiental, bem como a manutenção dos eixos de rios e córregos que fazem parte da identidade local. Pensando na mesoestrutura como elemento de manutenção do fluxo das redes fundamentais à ocupação, é necessário apontar caminhos para que os seus diversos sistemas sejam direcionados de forma igualitária à toda a população. Sendo a superestrutura a camada relacionada à própria ocupação no âmbito material e imaterial, é importante considerar que em áreas com traços rurais ainda preservados existem questões culturais relevantes e por isso deve-se adotar ações para que a história e a cultura tradicional não se percam. Destaca-se também o papel essencial da participação cidadã no reconhecimento e

\section{REFERÊNCIAS}

[1] Carvalho, Edézio Teixeira de. Geologia urbana para todos: uma visão de Belo Horizonte. Belo Horizonte: 1999.

[2] Costa, Geraldo Magela; Santos, Reinaldo Onofre dos; Costa, Heloisa Soares de Moura. Reflexões metodológicas sobre a relação ruralurbano a partir da teoria e de evidências socioespaciais da RMBH. Geografias, artigos científicos (periódico). Vol. 9, no 2, Belo Horizonte, 2013.

[3] Hespanhol, Rosangela Ap. de Medeiros. Campo e cidade, rural e urbano no Brasil contemporâneo. Publicado em: Mercator, Fortaleza, v. 12, número especial (2), p. 103-112, set. 2013.

[4] Iphan - Instituto do Patrimônio Histórico e Artístico Nacional. Carta de Atenas. 1933. Assembléia do Ciam - Congresso Internacional de Arquitetura Moderna. 38p.

[5] Memória Arquitetura. Projeto de restauração em Ravena, Sabará, MG. Disponível em:

<http://memoriaarquitetura.com.br/projetos/projetode-restauracao-em-ravena-sabara/>. Acesso em mar. de 2017

[6] Minas Gerais. Governo do Estado. Áreas urbanas centrais RMBH: Confins, Lagoa Santa, Ribeirão das Neves, Sabará, Santa Luzia. Minas Gerais: Governo do Estado de Minas Gerais, 2011. $195 p$.

[7] Minas Gerais. Instituto Estadual do Patrimônio Histórico e Artístico. Guia de bens envolvimento de qualquer processo de planejamento, para o desenvolvimento de políticas públicas que referenciem suas identidades.

Até então, o PDDI e as legislações municipais procuram reforçar o papel do distrito como uma centralidade, muito devido a sua posição estratégica em importante eixo viário estadual. Entretanto é importante questionar se o conceito de centralidade e a própria noção de macrozoneamento do PDDI podem assegurar os aspectos rurais existentes no território. $\bigcirc$ apontamento de questões regionais relevantes, especificidades e evolução histórica da ocupação é fundamental para a definição de políticas de planejamento em territórios com forte presença de traços físicos e imateriais de ruralidades, na tentativa de minimizar o efeito da urbanização "predatória" capitalista que não considera o contexto ambiental, social e cultural dos territórios.

tombados lepha/Mg. Volume 1, 2. ed. Belo horizonte, 2014. 296p.

[8] Monte-Mór, Roberto Luís. A Relação Urbano-Rural no Brasil Contemporâneo. II Seminário Internacional sobre Desenvolvimento Regional. Programa de Pós-Graduação em Desenvolvimento Regional. Mestrado e Doutorado. Santa Cruz do Sul, RS - Brasil, 2005.

[9] Pddi, Construindo um macrozoneamento metropolitano (cartilha). Belo Horizonte: 2013/2014. Disponível

em: <http://www.rmbh.org.br/arquivos_biblioteca/MZ_c artilha.pdf>. Acesso em mai. de 2017.

[10] Rua, João. A resignificação do rural e as relações cidade-campo: uma contribuição geográfica. Núcleo de Estudos da Geografia Fluminense (Negef) do Departamento de Geografia da UERJ. Revista da Anpege, v.2, n.2, p.45-66, 2010 .

[11] Talaska, Alcione; Silveira, Rogério Leandro Lima da; Etges, Virginia Elisabeta. Cidade e campo: para além dos critérios e atributos, as relações e contradições entre o urbano e o rural. Biblio 3W. Revista Bibliográfica de Geografía y Ciencias Sociales. Vol. XIX, no ${ }^{-1090 . ~ B a r c e l o n a: ~}$ Universidad de Barcelona, 2014.

[12] Vasconcellos, Salomão. Como nasceu Sabará. Revista do Iphan, Rio de Janeiro, n. 09, p.291-330, 1945. (Iphan, Rio de Janeiro). Disponível em: <http://portal.iphan.gov.br/uploads/publicacao/Rev Pat09_m.pdf>. Acesso em mai. de 2017 


\section{Capítulo 2}

\section{URBANIZAÇÃO E DESASTRE: O PROCESSO DE REASSENTAMENTO DA POPULACÃO DE BENTO RODRIGUES, MARIANA, MINAS GERAIS}

\section{Breno Fonseca de Araujo}

Gabriela Mara Batista de Sousa

Paula Pires Santos Pereira Thomaz

Resumo:O artigo irá apresentar e investigar as estratégias adotadas pela mineradora Samarco, responsável pelo rompimento da Barragem de Fundão, em 05/11/2015, Mariana, Minas Gerais, para promover as discussões do projeto urbano para o reassentamento da população atingida de Bento Rodrigues. Analisaremos também a atuação de outros atores como Ministério Público de Minas Gerais, ativistas e movimentos sociais, universidades dentre outros. $O$ artigo parte das discussões sobre urbanização extensiva para interpretar tanto o evento do desastre tecnológico bem como as soluções de projeto apresentadas até o momento para a população atingida, verificando e analisando as contradições que têm ocorrido dentro deste processo. Posteriormente, uma alternativa para a discussão da proposta de reassentamento será apresentada. ${ }^{17}$

Palavras-chave: Urbanização Extensiva; Reassentamento; Processo colaborativo

GT-1: Reestruturação Urbana: agentes, redes, escalas e processos espaciais

\footnotetext{
${ }^{17}$ Este artigo é inspirado nas reflexões desenvolvidas na pesquisa "URBANIZAÇÃO E DESASTRE: O caso de reassentamento de Paracatu de Baixo, Mariana, Minas Gerais" orientado pelo professor Tiago Castelo Branco Lourenço e na disciplina Arquitetura e Urbanização Contemporâneas ministrada pela professora Simone Parrela Tostes.
} 


\section{INTRODUÇÃO}

Em 05 de novembro de 2015, a barragem de rejeitos de minério de ferro de Fundão, propriedade da mineradora Samarco, localizada próximo aos distritos de Mariana, Minas Gerais, rompeu-se despejando resíduos minerários no Rio Gualaxo do Norte, atingindo logo em seguida o Rio Carmo e posteriormente o Rio Doce. O resíduo soterrou casas, escolas e pessoas, dizimou fauna e flora e impediu a captação de água do rio em várias cidades de Minas Gerais e Espírito Santo. Este evento é desde então considerado um dos maiores desastres ambientais ocorridos no mundo, e o maior dentre os que envolvem as atividades de extração de minério de ferro em todo o planeta. Dentre os distritos atingidos, o mais afetado foi o de Bento Rodrigues (Fig. 1 e 2), no município de Mariana, que ficava à margem do Rio Gualaxo do Norte.

Figura 1: Bento Rodrigues em 07/07/2013

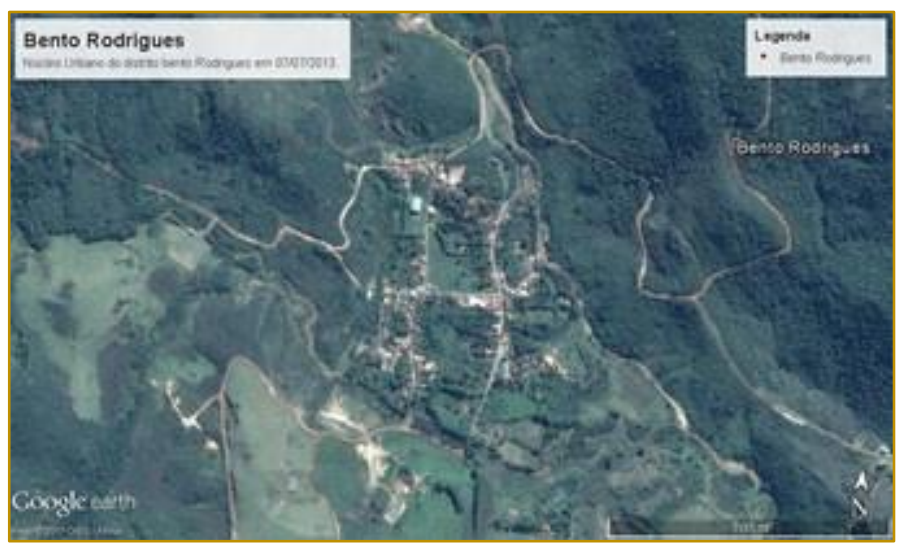

Fonte: Google Earth (acesso em 02. jun. 2017).

Figura 2: Bento Rodrigues em 26/07/2016

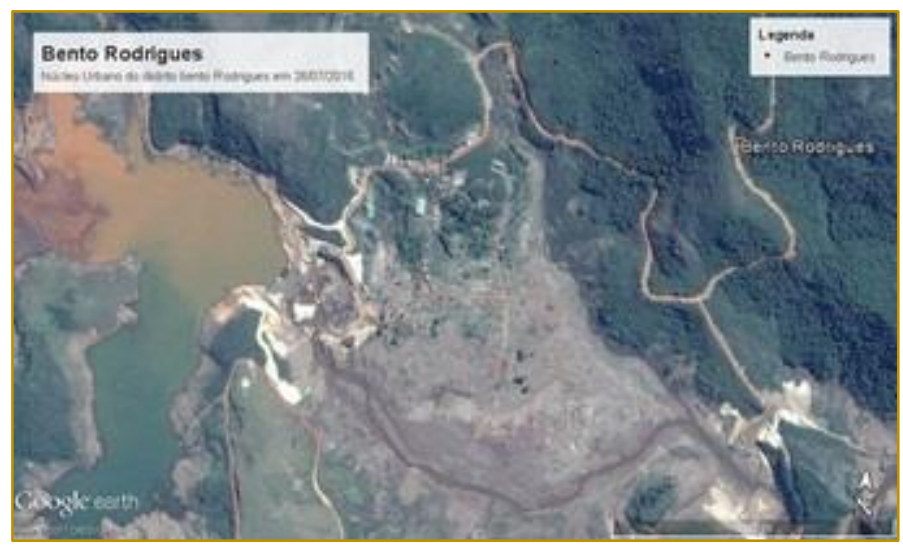

Fonte: Google Earth (acesso em 02. jun. 2017).

O rompimento da barragem de Fundão alterou significativamente $\mathrm{O}$ distrito. $\mathrm{A}$ proporção da destruição do povoado com fortes características rurais foi tão impactante que não permitiu a permanência das suas populações naquele lugar. Neste artigo trabalhamos com o conceito de lugar de Marcelo Lopes de Souza (2013, p.36):
(...) O 'lugar', aqui neste livro, não é 'qualquer lugar', um sinônimo abstrato de localidade; ele é um espaço dotado de significado e carga simbólica, ao qual se associam imagens, muitas vezes conflitantes entre si: lugar de 'boa fama' ou de 'má fama', hospitaleiro ou perigoso, e assim segue. 0 lugar é, em princípio, um espaço vivido: 
vivido, claro, pelos que lá moram ou trabalham quotidianamente. (...). (Souza, 2013, p.36)

Logo após o desastre, o Ministério Público de Minas Gerais - MPMG, através de sua representação em Mariana, assumiu um importante protagonismo na busca de resoluções para a restituição dos direitos da população atingida. Esses primeiros momentos foram essenciais para colocar esse ator como um dos mais importantes na condução de várias ações que têm sido realizadas no município, para a resolução dos problemas advindos com o rompimento da barragem. Nos primeiros meses foram vários os grupos políticos, movimentos e ativistas sociais, cidadãos de diferentes origens, que se dirigiram a Mariana para, num ato de solidariedade, auxiliar nas questões imediatas que envolviam o acontecido.

Após esses primeiros momentos de forte comoção que levaram a este expressivo afluxo de pessoas para a cidade, alguns movimentos e ativistas sociais além de grupos de extensão e pesquisa vinculados a universidades instaladas em Minas Gerais, foram se aproximando da situação com uma perspectiva de realizar uma atuação de longo prazo, já que os problemas gerados pelo desastre eram de grande complexidade.

Em um segundo momento foi percebido pelo MPMG e estes grupos a necessidade da formação de uma assessoria técnica que acompanhasse os atingidos nas diferentes reuniões e audiências que eles estavam sendo submetidos pela Samarco. A empresa, logo após o desastre, começou a mobilizar recursos de variadas naturezas para resolver imediatamente o ocorrido e com isso voltar a operar suas atividades de extração de minério de ferro.

Em resposta à falta de representatividade das populações atingidas, a Cáritas Brasileira foi contratada pelo MPMG, em outubro de 2016, como assessoria técnica que representasse e acompanhasse os atingidos, dispondo de advogados, arquitetos, engenheiros, assistentes sociais, psicólogos dentre outros profissionais. A Samarco, empresa da BHP Billiton $^{18}$ e Vale ${ }^{19}$, criou uma entidade que

\footnotetext{
${ }^{18} \mathrm{BHP}$ Billiton é uma mineradora e petrolífera angloaustraliana com atividades em todo o mundo, no Brasil ela é proprietária associada com a Vale da empresa Samarco. É considerada a maior empresa de mineração do mundo.
}

responde por ela e conduz os procedimentos de restituição de direitos dos atingidos, a Fundação Renova, como parte dos acordos com o Estado para a resolução dos problemas gerados pelo rompimento da barragem. Esta entidade tem a missão de implementar e gerir os programas de reparação, restauração e reconstrução das regiões impactadas pelo desastre.

O procedimento da Samarco, o mesmo adotado pela Fundação Renova, de dar agilidade a reconstrução e reassentamento dos lugares atingidos foram marcados por uma grande violência. Estas violações ficaram evidentes no modo com que a empresa atuava e ainda atua, contratando profissionais para conduzir os procedimentos num formato burocrático, que rejeita possibilidades colaborativas que valorizem os modos de vida dos atingidos no cotidiano dos lugares afetados. É importante frisar que a busca por uma rápida resolução da situação tem gerado padrões de urbanização e de produção do espaço que desrespeitam as características locais do distrito atingido. $O$ processo realizado de forma acelerada tem sido pouco cuidadoso e tem acentuado ainda mais a violência do desastre ocorrido.

Para exemplificar como tem ocorrido esse processo, apresentamos como tem se dado os encaminhamentos para o reassentamento da população atingida no Novo Bento Rodrigues. A primeira fase de planejamento da reconstrução por parte da Fundação Renova foi um estudo para escolha do local de construção do novo distrito. A escolha do terreno apresentado pela mineradora aconteceu após um período de aproximadamente três meses após o desastre, onde os atingidos não contavam com técnicos que pudessem representar seus interesses e instigar discussões utilizando de tecnologia e linguagem acessível. Os documentos foram entregues apenas cinco dias antes da assembleia marcada para a votação. O documento que fundamentou esta escolha era, como é recorrente no setor técnico, formatado e apresentado com uma linguagem complexa, situação que gerou várias dúvidas e dificuldade de entendimento em relação ao seu conteúdo e consequente decisão sobre os terrenos.

\footnotetext{
${ }^{19}$ Vale, antiga Companhia Vale do Rio Doce (2007) é uma mineradora multinacional brasileira. É uma das maiores empresas de mineração do mundo.
} 
Para o andamento dos trabalhos a Fundação Renova inventariou bens, quantificou e mapeou os atingidos, realizou levantamentos cadastrais, na tentativa de identificar as características populacionais, considerando o procedimento como participativo e suficiente como referência para nortear as diretrizes do projeto de reassentamento. Em assembleias gerais, sem uma escuta atenta, utilizando de estratégias quantitativas e massivas, que desconsideram as individualidades, eram discutidos e aprovados terrenos e projetos urbanísticos, por meio de placas de sinalização dos desejos de cada atingido que indicavam "sim" (na cor verde) ou "não" (na cor vermelha).

Para pensar essa condição entendemos que as discussões sobre a "urbanização extensiva" desenvolvida por Roberto Luís de M. Monte-Mór, serão úteis para a problematização das relações e fronteiras entre o espaço urbano e rural transformados pelas forças capitalistas. No caso analisado, partimos do princípio de que o próprio desastre é fruto desse processo de urbanização extensiva. Embora Bento Rodrigues fosse núcleo urbano isolado dentro da área rural do município de Mariana, ele participava de uma expansão do urbano, advindo do avanço da industrialização e da consequente urbanização (extensiva), com grande influência sobre o território.

Com o evento do rompimento da barragem de Fundão, a lógica da urbanização se impõe apagando os resquícios de uma outra urbanidade construída durante 300 anos a partir de outros pressupostos de cidade, promovendo então a desterritorialização. Nesse sentido, entendemos que "(...) uma territorialização ou desterritorialização é, sempre e em primeiro lugar, um processo que envolve o exercício de relações de poder e a projeção dessas relações no espaço (...)" (Souza, 2013, p.102).

Do desastre analisado, entendemos que as formulações teóricas que cercam a concepção da "urbanização extensiva" acentuam a violência das ações para a restituição dos direitos da população atingida, tornando ainda mais drástica a ruptura com os modos de vida existente antes do rompimento da Barragem de Fundão.

A Fundação Renova e seus técnicos conduzem a resolução dos problemas gerados pelo desastre como uma oportunidade de superar o "atraso" da vida rural, desconsiderando os processos sociais que existiam nos territórios arrasados pela lama de rejeitos minerários. A oportunidade de estender a lógica e inclusive o tecido urbano é perceptível nos planos urbanísticos apresentados para a população atingida para o novo território, conhecido como Lavoura.

O nosso contato com essa situação se deu a partir da nossa experiência como extensionistas do Escritório de Integração do curso de Arquitetura e Urbanismo, e foi ampliado pela disciplina Metodologias colaborativas: o caso de Mariana. Tomando como ponto de partida as experimentações acima citadas, desenvolvemos uma pesquisa como bolsistas do PROBIC ${ }^{20}$, desde março de 2017. Tal pesquisa denominada "URBANIZAÇÃO E DESASTRE: O caso de reassentamento de Paracatu de Baixo, Mariana, Minas Gerais", investiga como tem sido elaborado e apresentado o projeto para o novo núcleo urbano a ser construído para os atingidos que moravam em Paracatu de Baixo.

Neste artigo será apresentado o material referente ao Novo Bento Rodrigues, apesar da pesquisa se debruçar sobre outro lugarejo, tem se evidenciado que os procedimentos aplicados pela Fundação Renova para as discussões com a população de Bento Rodrigues serão replicados para outros lugares, dentre eles Paracatu de Baixo.

\section{A PROPOSTA DA FUNDAČÃO RENOVA PARA REASSENTAMENTO DOS ATINGIDOS DE MARIANA}

Neste artigo iremos exemplificar o processo de encaminhamento das propostas, apresentando trechos de um caderno entregue aos atingidos, "Reconstrução de Bento Rodrigues - Projeto Urbanístico". O intuito deste caderno era o de apresentar aos moradores o plano urbano que estava sendo estudado para implantação no terreno escolhido no início de abril de 2016.

A linguagem gráfica adotada pelo material indica uma certa infantilização dos sujeitos, buscando uma linguagem que os desqualifica e os coloca como indivíduos não aptos a realizar aquela discussão "técnica". Observase a tentativa de convencer os atingidos em

20 Programa de Bolsas de Iniciação Científica patrocinado pela FAPEMIG - Fundação de Amparo à Pesquisa 
relação aos parâmetros urbanísticos que atualmente regem a legislação urbana municipal. O lugar que antes se conformava como um pequeno núcleo num meio rural é tratado como mais uma área urbana, uma cidade, que na verdade não existia. Em um primeiro momento, o caderno traz a definição de um projeto urbanístico, como sendo "(...) o desenho do distrito no novo terreno, com a distribuição das ruas, dos limites dos quarteirões e dos lotes onde serão construídas as casas, igrejas, escola, posto de saúde, praças, entre outros equipamentos públicos" (Caderno reconstrução de Bento Rodrigues, projeto urbanístico, 2016, p.3). Essa afirmação, além de subestimar a complexidade de uma urbanização, reduz a reparação às questões físicas e legais que envolvem um processo de urbanização, não considerando outras questões importantes que dizem respeito aos elementos imateriais e intangíveis, que neste caso assumem um importante papel para que ocorra de fato uma reparação dos danos causados pelo desastre.

O caderno apresenta o processo de construção do reassentamento do novo Bento Rodrigues através de uma sequência de mapas e imagens de satélite que ilustram desde o traçado e a conformação do antigo (Fig. 3) até o novo território deste distrito.

$\mathrm{Na}$ leitura do caderno evidencia-se que o traçado do Novo Bento Rodrigues terá como referência o antigo, numa tentativa pouco eficiente de reproduzir o que existia, sendo que 0 terreno escolhido para 0 reassentamento tem características morfológicas completamente diferentes: o antigo Bento Rodrigues se encontrava implantada na margem de um curso d'água num grande fundo de vale, o terreno escolhido é uma meia encosta recortada por pequenos vales com córregos estreitos.

Figura 3: Autodelimitação dos lotes do antigo Bento Rodrigues

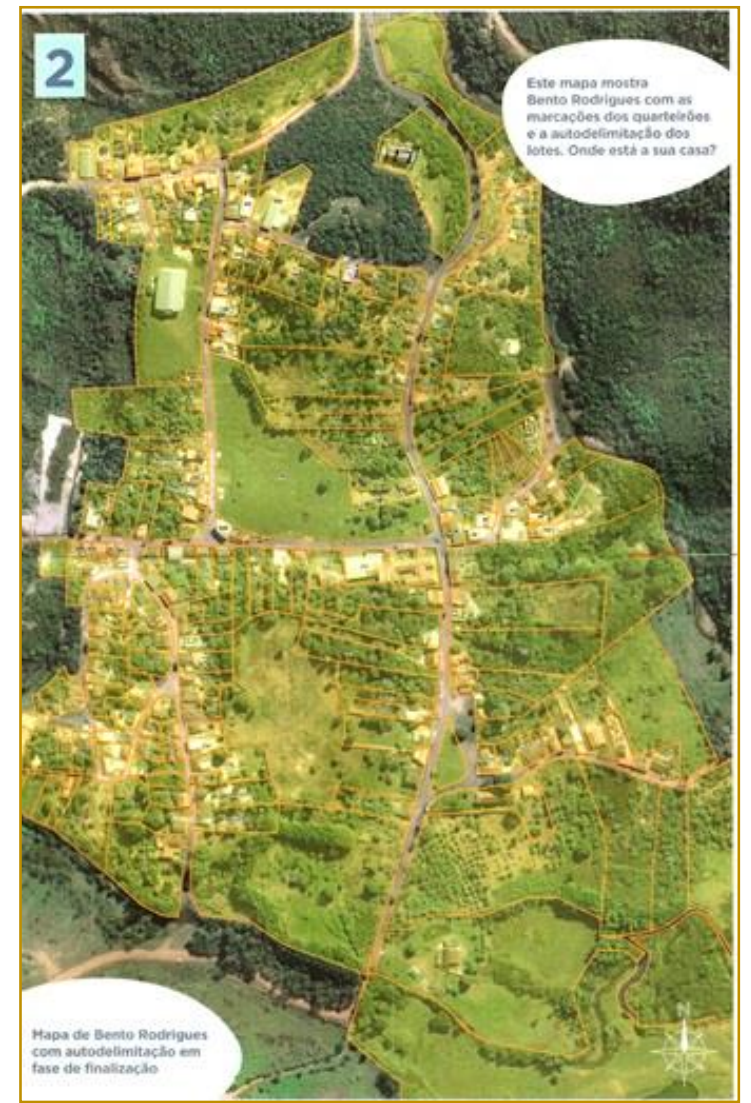

Fonte: Caderno Reconstrução de Bento Rodrigues - Projeto Urbanístico 
O exercício de apresentação dos parâmetros urbanísticos contemporâneos da cidade de Mariana, que serão aplicados no traçado urbano do Novo Bento, é realizado através da apresentação do sistema viário do Bento Rodrigues original, este que se configurava com suas ruas tortuosas, abertas com o passar dos anos sem o compromisso com um desenho ortogonal e retificado, construídas cotidianamente por seus moradores, sem o auxílio de técnicos especializados na produção do espaço (Fig. 4).

Figura 4: Poligonal de Bento Rodrigues

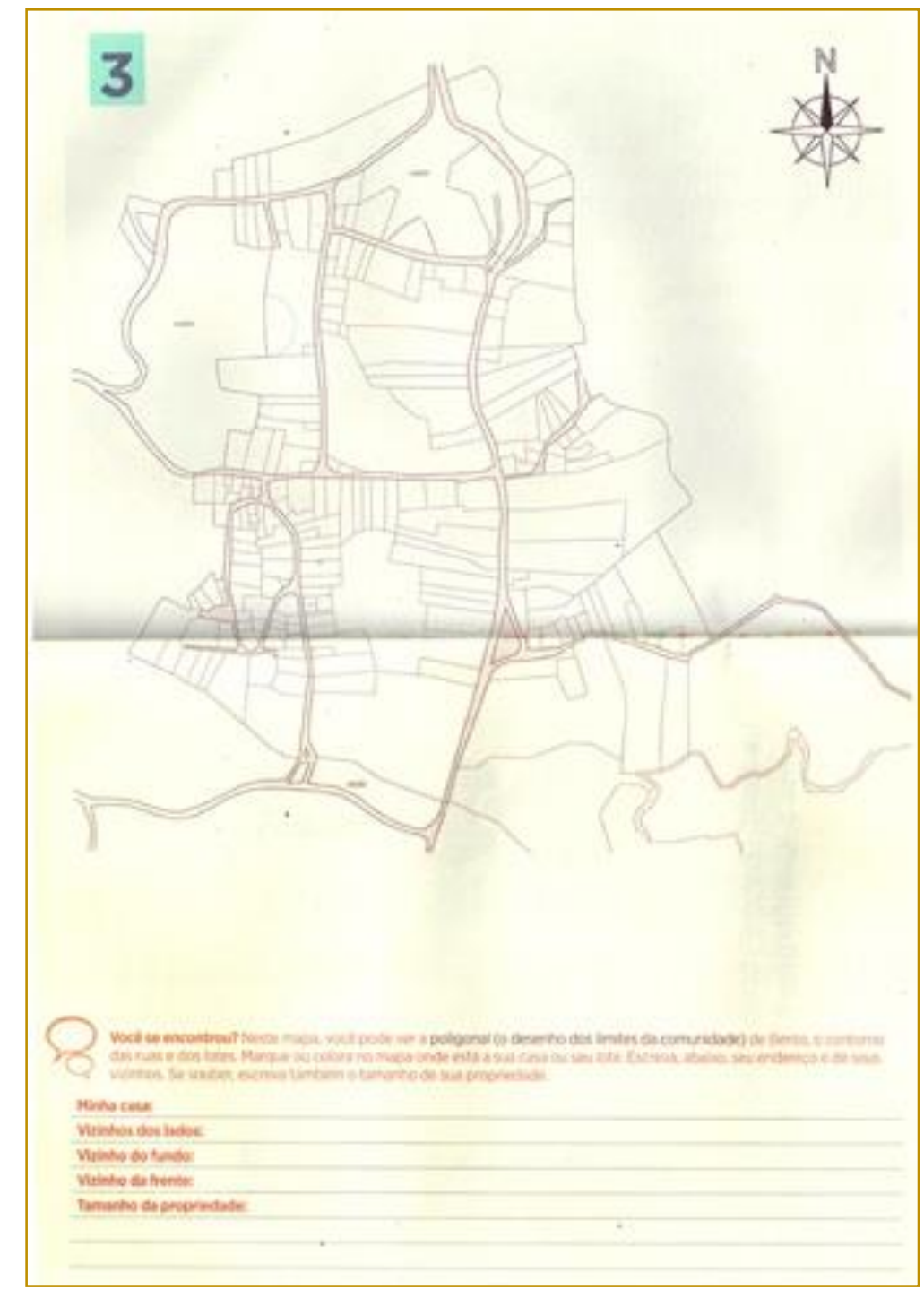

Fonte: Caderno Reconstrução de Bento Rodrigues - Projeto Urbanístico

Posteriormente é apresentado o mesmo Bento Rodrigues original, agora com as ruas retificadas, rotatórias nas ruas sem saída, dentre outros atributos de traçados urbanos que marcam o desenho viário das cidades contemporâneas, reforçando a ideia de desconsiderar os processos de autoprodução de núcleos urbanos como Bento Rodrigues (Fig. 5). 
Figura 5: "Ajustando o desenho antigo de Bento, de acordo com a lei que existe hoje"

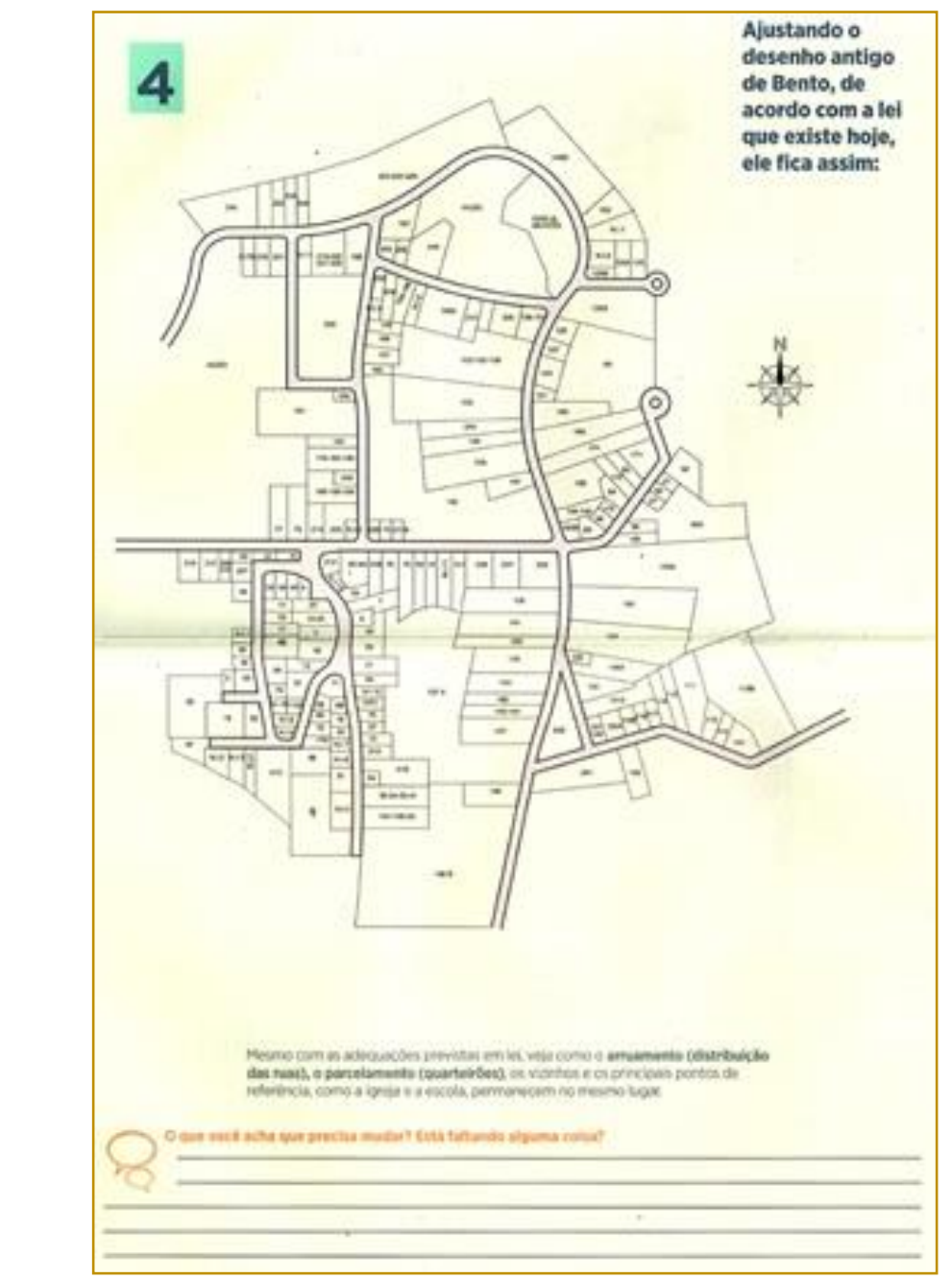

Fonte: Caderno Reconstrução de Bento Rodrigues - Projeto Urbanístico

Uma das principais questões a serem levantadas é a forma como o projeto foi apresentado, em nenhum momento é evidenciado as diferenças morfológicas entre o terreno do antigo Bento (fundo de vale) e o novo Bento (meia encosta). Esse tipo de apresentação, em duas dimensões, restringe a leitura da real inserção das construções no terreno escolhido, ludibriando a interpretação dos moradores e suas relações com o todo.

O material encaminhado ainda apresenta a estratégia de comunicação que remete aos encartes publicitários de lançamentos imobiliários, com desenhos sedutores que pouco esclarecem o que de fato importa, não deixando evidente os elementos polêmicos para que 0 atingido possa tomar suas decisões para a reparação dos danos causados pelo desastre. Esta situação chama a atenção no caso do terreno da "Lavoura" (Fig. 6), (escolhido para o reassentamento dos atingidos de Bento Rodrigues), nas proximidades do terreno está em operação o aterro sanitário da cidade de Mariana, como este fato é polêmico e pode gerar empecilhos para a decisão, ele é negado nos desenhos deste encarte. Estão destacados os elementos que agregam valor para escolha do terreno pelos atingidos, elementos como cachoeiras, cavernas, árvores frutíferas centenárias. 
Figura 6: Ilustração do terreno da Lavoura

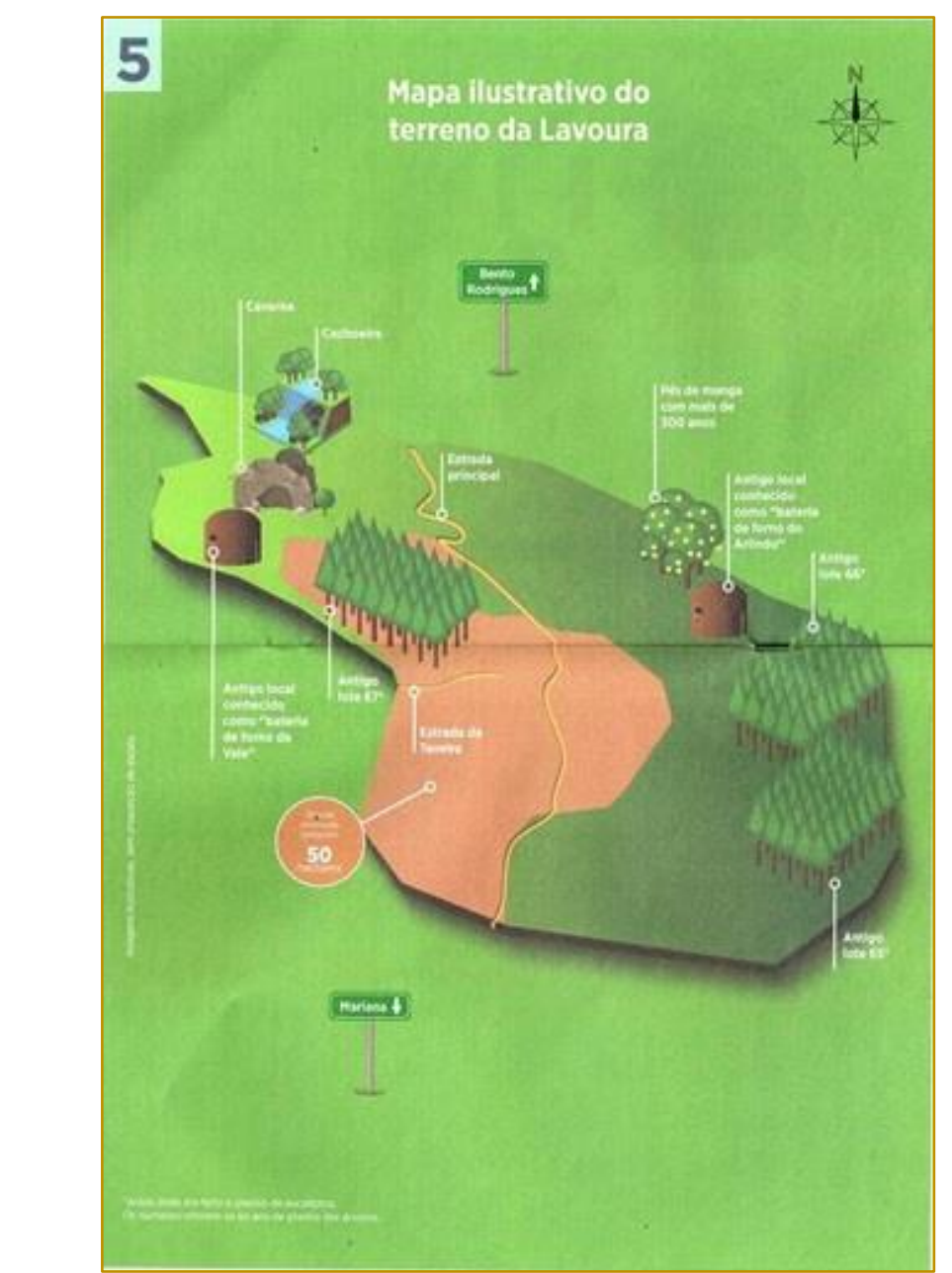

Fonte: Caderno Reconstrução de Bento Rodrigues - Projeto Urbanístico

Este caderno é uma evidência de como tem acontecido os procedimentos da Fundação Renova para promoção da "participação" dos atingidos nas decisões que envolvem 0 reassentamento do distrito.

\section{UMA POSSÍVEL ALTERNATIVA PARA A CONSTRUÇÃO DA PROPOSTA DE REASSENTAMENTO DOS ATINGIDOS DOS DISTRITOS DE MARIANA}

Frente a esse cenário de discussões pouco colaborativas, a Cáritas Brasileira em parceria com a ASF Brasil e o Escritório de Integração ${ }^{21}$, elaboram uma tecnologia social capaz de facilitar o diálogo entre técnicos e atingidos, de modo a promover o

\footnotetext{
${ }^{21} \mathrm{El}$ - Escritório de Integração; pertencente ao departamento de Arquitetura e Urbanismo, ligado à prática de extensão. Atua na articulação entre ensino, pesquisa e extensão.
}

empoderamento dos moradores no processo de discussão do reassentamento.

Elaborou-se uma oficina com a população de Bento Rodrigues, cujo conceito baseava-se na escala - corpo, casa, espaço. A criação desta oficina ocorreu durante quatro encontros, no El e na cidade de Mariana, compatibilizando as ideias sugeridas e propiciando a participação de todos. Nesta concepção, o participante vivenciaria as distintas escalas, buscando entender a espacialidade do terreno escolhido, a Lavoura, e do plano urbanístico - Masterplan proposto para a área.

Visando a materialização da proposta, a Cáritas especificou que a oficina deveria ser pensada para aproximadamente cem pessoas, e nesse sentido o formato de circuito seria o mais adequado, já que permite a divisão dos participantes em grupos menores. A oficina ocorreu em Mariana, nos dias 10, 13, 14 e 15 de março de 2017, com a 
duração de 3 horas e teve participação de aproximadamente 35 famílias por dia.

O plano urbanístico de Bento Rodrigues foi dividido em setores, (Fig. 7) de forma que os moradores de uma mesma região pudessem participar juntos, em um mesmo dia.

Nessas oficinas, os atingidos passaram por quatro diferentes etapas, sendo as três primeiras de reconhecimento e a última delas uma síntese das reivindicações e mudanças no plano de reassentamento. A seguir, apresentaremos as etapas da oficina realizada.

Figura 7: Ilustração dos setores de Bento Rodrigues

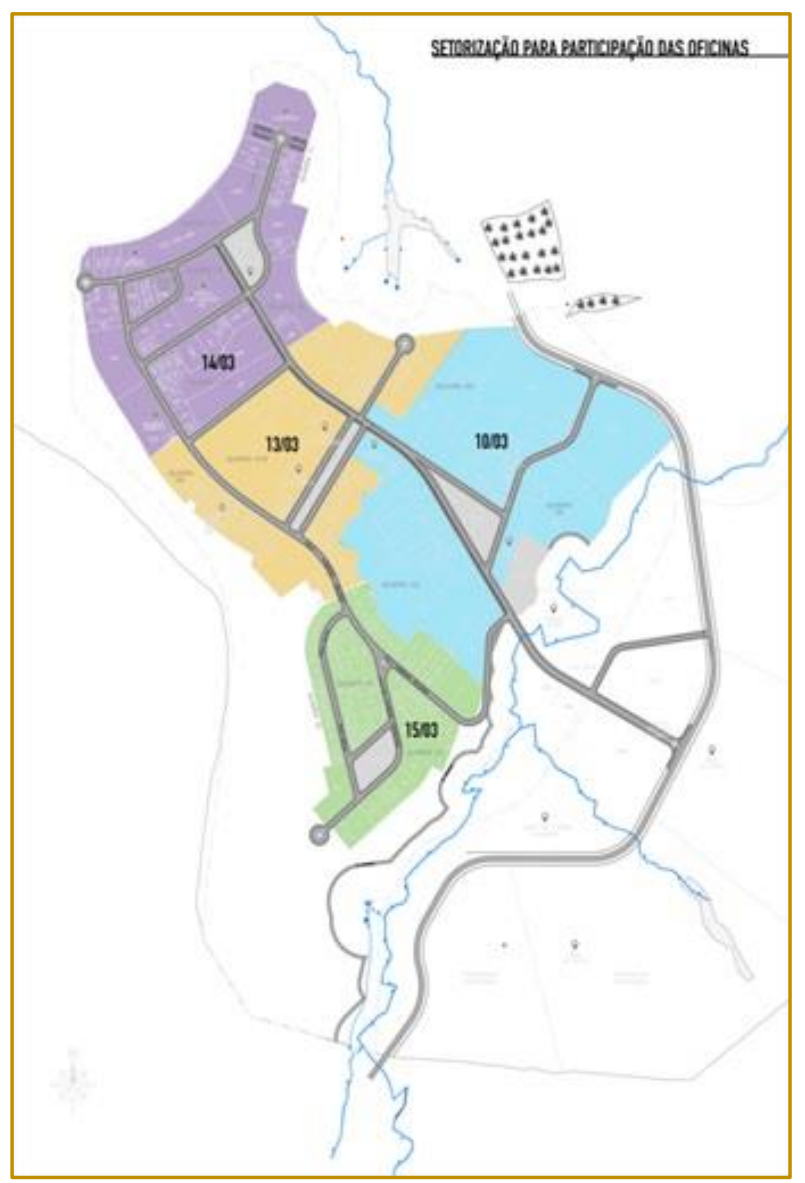

Fonte: Relatório final da Oficina elaborado pela Cáritas Brasileira

\subsection{PRIMEIRA ETAPA}

Visando o entendimento dos moradores acerca do novo terreno - a Lavoura - a primeira etapa consistiu na apresentação de uma filmagem de sobrevôo produzida com o auxílio de um drone.

Na prática, porém, a presença dos eucaliptos existentes no terreno mascarou um relevo consideravelmente íngreme, além dos limitados recursos hídricos da região. Ademais, a falta de um referenciamento, por se tratar de uma grande área sem construções, também dificultou o entendimento dos atingidos. Foi necessário que se apontasse para alguns atingidos onde estaria a estrada, em qual sentido ficava Mariana, entre outras referências.

Em suma, a primeira etapa (Fig. 8) foi válida para que aqueles que ainda acreditavam ser possível replicar o distrito antigo no novo terreno percebessem que isso não aconteceria: o traçado deverá se adequar ao novo local, assim como todo o Masterplan. 
Figura 8: exibição do vídeo do sobrevôo na área da Lavoura

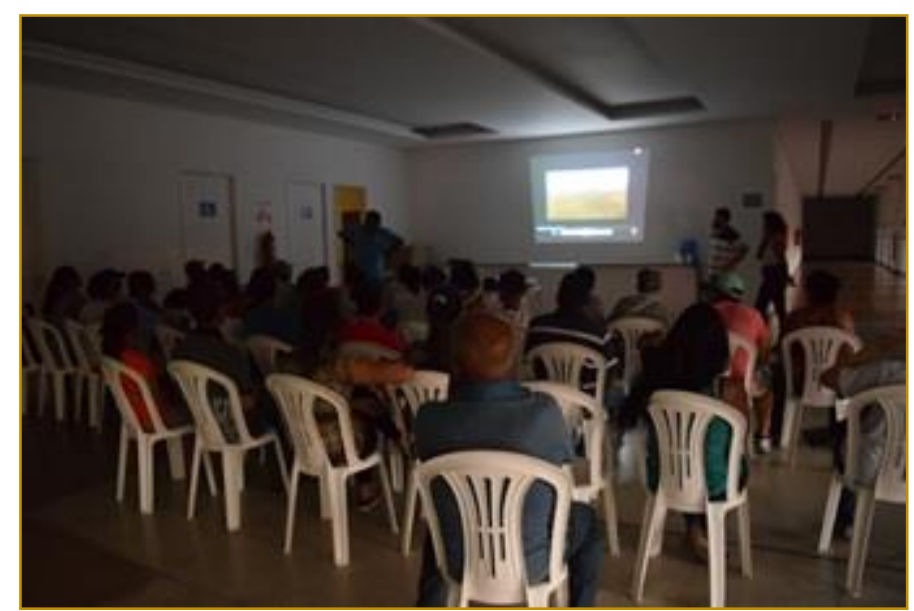

Fonte: Arquivo do Escritório de Integração

\subsection{SEGUNDA ETAPA}

Na segunda etapa, os trabalhos se resumiram no reconhecimento do terreno, por meio da comparação de maquetes que contemplavam a estrutura dos lotes antigo e novo. Foram dispostas, lado a lado, as duas maquetes na escala de 1:1000, em que uma estampava a imagem aérea de Bento antes do desastre e a outra a imagem aérea da Lavoura, com a divisão de lotes e o sistema viário elaborado pela Dávila Arquitetura (Dávila Arquitetura; é uma empresa de projetos de arquitetura e urbanismo contratada pela Fundação Renova para o desenvolvimento do plano urbano do Novo Bento Rodrigues. A empresa encontra-se sediada em
Belo Horizonte, Rio de Janeiro, São Paulo e Brasília. ) sobreposto às curvas de nível.

A segunda etapa da oficina (Figuras 9 e 10) cumpriu seu propósito quando os moradores perceberam a dinâmica do espaço, observando onde as novas ruas passariam no terreno, as relações de alturas e os empecilhos impostos pelo relevo da região. A leitura de um terreno "palpável" possibilitou aos moradores visualizar a composição do novo espaço, questionando as distâncias, tamanhos e posicionamentos das edificações coletivas - igreja, escola, cemitério - e dos loteamentos.

Figuras 9 e 10: Segunda etapa da oficina do dia 14 de março de 2017.
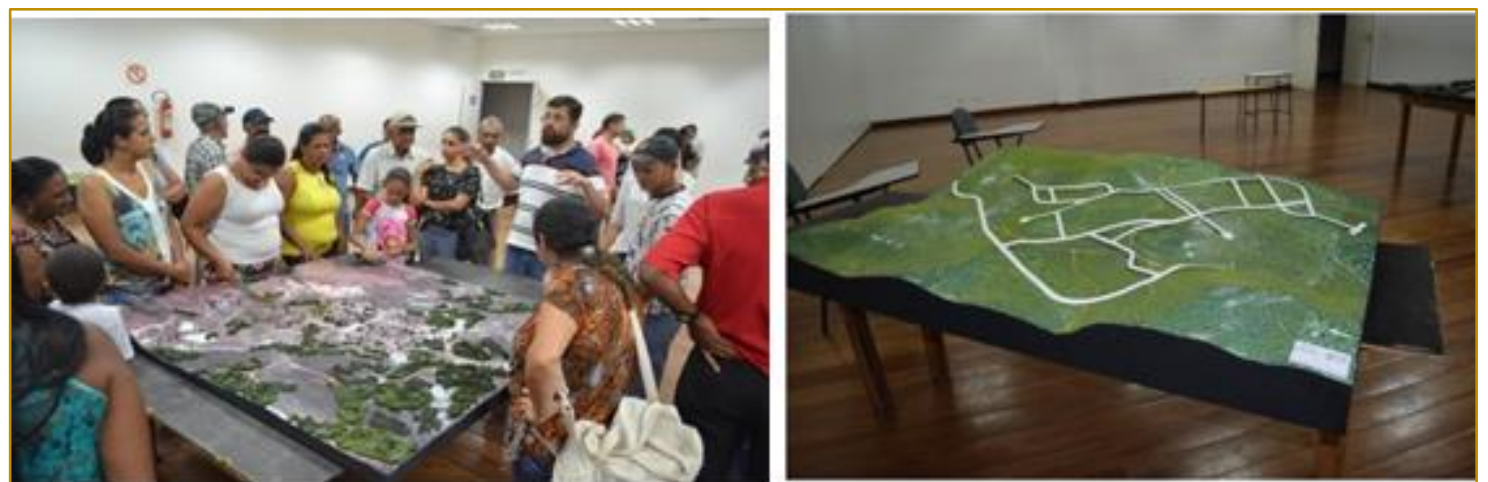

Fonte: Arquivo do Escritório de Integração

\subsection{TERCEIRA ETAPA}

A terceira etapa do circuito compreendeu a experiência de imersão do plano urbanístico do Novo Bento. A proposta se concretizou através de uma planta baixa na escala de $1: 200$, o que gerou uma imagem de aproximadamente $5 \times 7$ metros (Fig. 11), onde cada metro no papel corresponde a 200 metros de terreno "real". Desta forma, os participantes puderam andar sobre o sistema viário proposto, entender o loteamento e a localização de áreas de uso público, e ainda 
desenhar ou escrever na planta qualquer observação/reivindicação/sugestão mudança.

Figura 11: Terceira etapa da oficina do dia 11 de março de 2017.

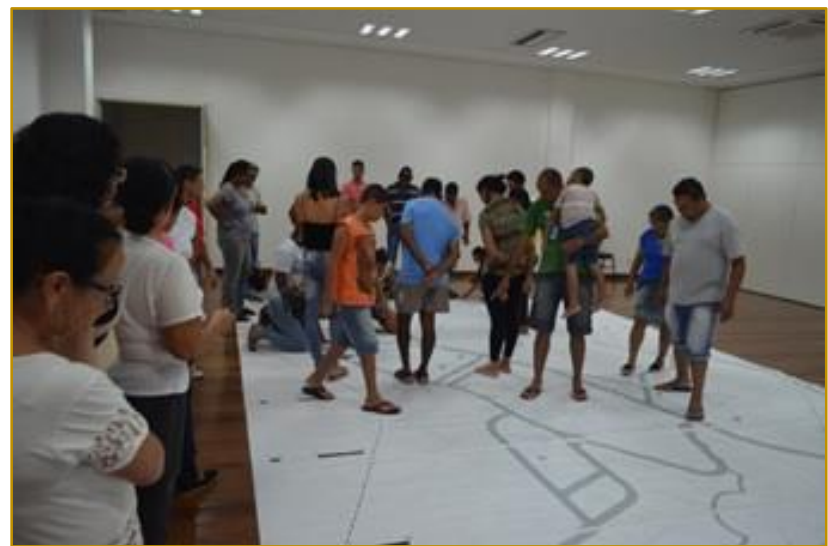

Fonte: Arquivo do Escritório de Integração.

A terceira etapa foi a mais vivenciada pelos atingidos (Fig. 12), que por meio da "escala corpo", puderam compreender e identificar os prós e contras da nova implantação. Nessa oficina, os moradores apontaram oposições e desejos para a Nova Bento, como uma capela velório no cemitério, uma ciclovia na estrada externa ao distrito, além da reivindicação de que seus lotes fossem alocados com a mesma configuração a que estavam acostumados - de frente a praça, na esquina, fazendo divisa com o vizinho antigo, entre outros.
A representação da figura humana na mesma escala mostrou-se importante para entender principalmente a largura proposta para as vias. Ao comparar a escala do corpo e a largura da sala onde ocorria a oficina, concluíam, por exemplo, a extensa largura das ruas propostas e o impacto que geraria esse tipo de configuração, como a falta de interação entre os vizinhos - chamados antes pelas janelas frontais.

Figura 12: Estado final da uma parte da planta utilizada na terceira etapa

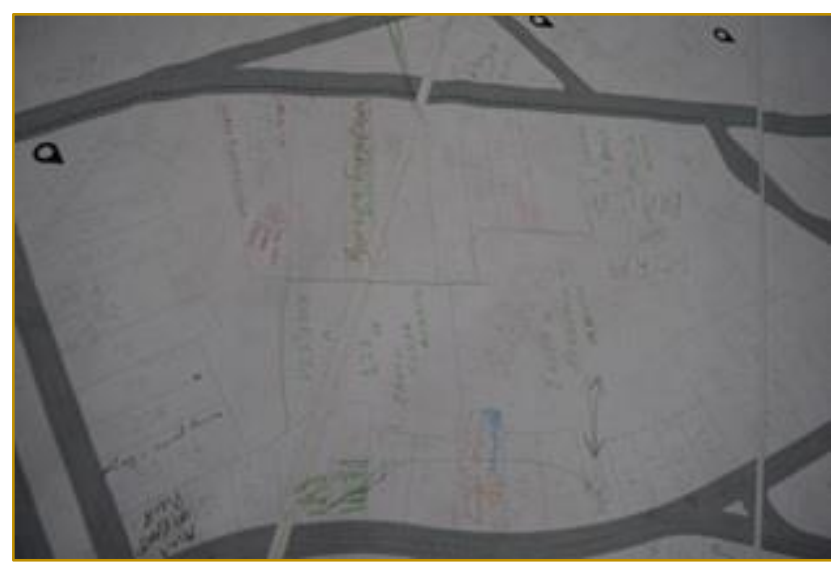

Fonte: Arquivo do Escritório de Integração.

\subsection{QUARTA ETAPA}

A quarta e última etapa se configurou como síntese do processo, em que os moradores retomavam a proposta da oficina se debruçando sobre uma planta, em escala
1:400, referente ao setor onde moravam no antigo lugarejo (Fig. 13). Fazendo uso de canetinhas e lápis de cor, eles sintetizariam suas observações feitas ao longo do circuito focando no seu setor específico e no interesse da coletividade. 
Alguns participantes não seguiram o caminho proposto para o circuito, seja porque o grupo estava dividido ou porque não estavam tão interessados na dinâmica. Essa ruptura enfraqueceu a capacidade de síntese da etapa, que serviu para muitos como um material de entendimento do plano urbanístico, assim como a etapa anterior.

Figura 13: Um grupo discute o projeto utilizando a representação na escala 1:400

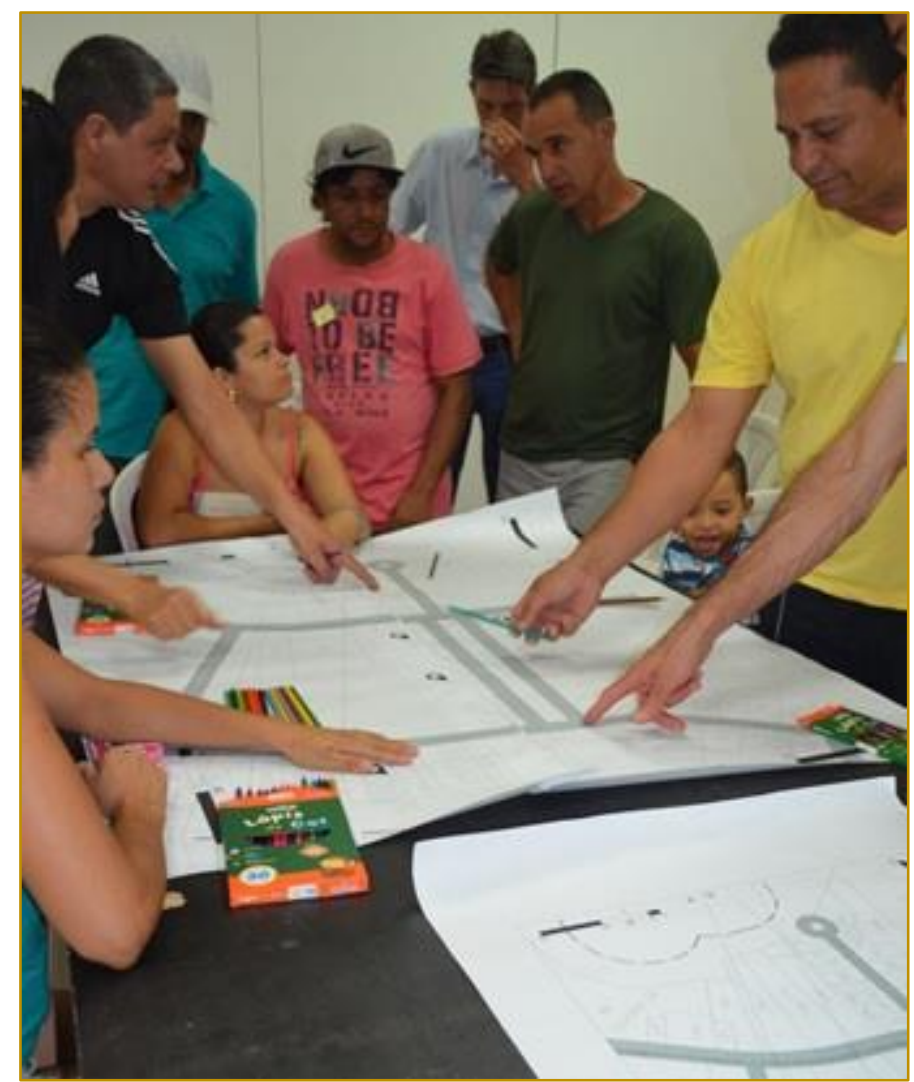

Fonte: Arquivo do Escritório de Integração.

A oficina buscou uma estratégia colaborativa, buscou a linearidade dos saberes técnicos e a experiência dos atingidos, ainda que, mesmo com esses esforços, o objetivo não tenha sido completamente atingido. Os encontros contribuíram para o entendimento do local e do projeto urbano proposto para a área de reassentamento, embora algumas questões precisam ser revistas em assessorias técnicas subseqüentes, além da busca por novos métodos de trabalho e novas tecnologias sociais. Em síntese, os atingidos se interessavam mais com as questões individuais, como a casa e o lote, do que com as questões coletivas como é necessário numa discussão do Masterplan do novo distrito.

\section{CONSIDERAÇÕES FINAIS}

O espaço vivido foi um elemento desconsiderado pelos responsáveis do desastre tecnológico do rompimento da Barragem de Fundão quando não deram a devida atenção aos elementos de segurança que impediriam o crime do dia 05/11/2015. O que mais preocupa nos processos que envolvem a restituição dos direitos dos atingidos, é que o espaço vivido continua não sendo considerado como dimensão a ser restituída aos atingidos dos distritos de Mariana. A Fundação Renova e em alguma medida também os representantes do Estado tem atuado de tal forma preocupados em restituir os elementos tangíveis que foram perdidos com o desastre e dado pouca atenção aos elementos intangíveis; elementos estes que davam sentido para as espacialidades que se perderam.

Durante o acompanhamento à população atingida de Mariana, observa-se que mesmo os movimentos e ativistas sociais bem como representantes do Ministério Público instituição do Estado mais atentas ao 
cotidiano das classes destituídas com uma atuação que busca garantir seus direitos não valorizam o cotidiano e a autoprodução como possibilidade de emancipação política, econômica, social e cultural das populações atingidas.

Esta constatação justifica a necessidade dos arquitetos e urbanistas rediscutir seus procedimentos para dar conta de uma situação como essa criada pelo desastre tecnológico da Samarco.

Discutir esse espaço construído no cotidiano se apresenta como um desafio necessário de ser enfrentado para que se potencialize as estratégias de apropriação por parte dos atingidos dos novos lugares que serão erguidos para o reassentamento.

Ao não tomar cuidado com o discurso técnico e criticá-lo quando necessário numa assessoria técnica sobre um lugar que foi construído a partir de outros valores numa outra temporalidade, preocupados somente com a restituição de direitos a partir dos valores contemporâneos, de uma urbanidade que nos distritos atingidos não existia, acabase não sendo dada a devida atenção aos procedimentos de autoprodução que os moradores destes lugares apresentavam no espaço vivido cotidianamente.

\section{REFRÊNCIAS}

[1] Bittencourt, Epaminondas. A tragédia de Mariana: 0 narcisismo gerencial na pósmodernidade - 1. ed. São Paulo: Chiado Editora, 2017.

[2] Feyerabend, Paul. A Ciência em uma sociedade livre. 1. Ed. São Paulo: Editora UNESP, 2011. 288p.

[3] Kapp, Silke. Direito ao espaço cotiano: moradia e autonomia no plano de uma metrópole. Caderno Metrópole, São Paulo, v.14, n.28, 2012.

[4] Marx, Karl; Engels, Friedrich. A ideologia alemã (Feuerbach). 10. ed. São Paulo: Editora Hucitec, 1996.
É comum não considerarmos as diferenças de origem na mobilização para restituição de direitos como no caso dos atingidos de Mariana, criando essa "ilusão" de que somos iguais. Com a consolidação das negociações para o reassentamento dos atingidos estas diferenças vão se evidenciando e nunca são discutidas, vão sendo neutralizadas por outras questões até que ocorrem momentos de ruptura, ou a construção de novos distritos que ficam desprovidos de significados para aquelas pessoas que lá irão morar.

Como essas diferenças não são discutidas, o receio e os atingidos ao retomarem as suas práticas cotidianas, abandonam as supostas conquistas das lutas pela garantia de restituição de direitos, retomando então práticas que remetem ao imaginário capitalista ao qual estavam submetidas, agora muito mais dependentes e com elementos que eles não sabem manipular já que foram criadas soluções para situações que antes não existiam.

A intenção deste artigo é chamar a atenção para a necessidade de romper com essa lógica perversa que mantém o cotidiano como um elemento desconsiderado, buscando dar voz para aqueles que destituídos de tudo tem que retomar suas vidas e reconstruir seus lugares no mundo.

[5] Monte-Mór, R. L. As teorias urbanas e o planejamento urbano no Brasil. Belo Horizonte: Editora UFMG, 2006.

[6] Souza, Marcelo Lopes de. Os conceitos fundamentais da pesquisa sócio-espacial. 1. ed. Rio de Janeiro: Editora Bertrand Brasil, 2013.

[7] Thompson, Paul. A voz do passado: História Oral. Petrópolis: Editora Vozes, 1992.

[8] Usina Ctah'e Rede Justiça nos Trilhos. As vacas têm para onde ir, o povo de Piquiá não: 0 reassentamento do Piquiá de Baixo e os caminhos do desenvolvimento brasileiro, in: Usina: Entre o Projeto e o Canteiro. - São Paulo: Edições Aurora, 2015. 


\section{Bapítulo 3}

\section{A CRIAÇÃO E EFETIVAÇÃO DA REGIÃO METROPOLITANA DE PALMAS-TO: CRITERIOS E PROCESSO DE INSTITUCIONALIZACÃO}

\section{Dalva Marçal Mesquita Soares \\ Celene Cunha Monteiro Antunes Barreira}

Resumo: Este artigo origina-se da tese de doutorado em Geografia na Universidade Federal de Goiás. Nele se objetiva discutir o processo de criação e efetivação da Região Metropolitana de Palmas (RMP), bem como os critérios e o processo de sua institucionalização. A partir de pesquisas realizadas na Assembleia Legislativa do Estado do Tocantins, na Unidade Estadual do Tocantins do IBGE, na Secretaria Estadual de Planejamento e Orçamento, de Infraestrutura, Habitação e Serviços Públicos e na Secretaria Municipal de Desenvolvimento Urbano e Habitação de Palmas, apresenta-se como ocorreu o processo de institucionalização da RMP e quais critérios foram utilizados. Assim, por meio de entrevistas e de um estudo analítico e dialético dos desenhos traçados pelos entrevistados, verificou-se que a RMP foi criada mediante interesses políticos e, no processo de sua institucionalização, não foram estabelecidos critérios para identificar sua configuração e verificar seu verdadeiro caráter metropolitano.

Palavras-chave: Região Metropolitana de Palmas (RMP); critérios e processo de institucionalização; configuração e caráter metropolitano. 


\section{INTRODUÇÃO}

O processo de metropolização contemporânea representa uma verdadeira transformação no modelo de urbanização. Essa nova fase tem como foco o novo sistema tecnológico e o modelo de governança baseado na liberação econômica. Dessa forma, os pólos urbanos tornam-se os centros de tomadas de decisões, direção e gestão, que representam as principais articulações das bases econômicas nacionais (LECIONI, 2011). O processo de metropolização decorre do resultado da polarização ao redor de uma grande cidade e considera as dimensões populacionais, estruturais e físicas. Assim, esse processo vislumbra-se de forma planejada ou não planejada.

A capital do Estado do Tocantins, Palmas, representa um modelo de metropolização planejada, por ter sido criada em 1989, com intuito de abrigar o aparelho administrativo do referido Estado, que foi instituído por meio da Constituição Federal de 1988, com a separação do extremo Norte Goiano, hoje Tocantins, do então sul de Goiás.

Atualmente, Palmas apresenta-se como a mais nova capital planejada do país e vem atraindo um grande índice populacional de quase todas as regiões do Brasil. Também conta com uma posição geográfica favorável, por estar localizada no Planalto Central Brasileiro e permitir uma maior integração com os demais estados da Federação.

Conforme censos demográficos publicados pelo IBGE, a capital apresentou entre 2000 e 2010 a maior taxa de crescimento anual de população entre as demais capitais do Brasil. $\mathrm{Na}$ capital do Tocantins, a taxa de crescimento foi de $5,2 \%$ em dez anos, proporcionando um processo de urbanização muito rápido. Ainda, segundo censo realizado pelo IBGE em 2010, Palmas apresentou uma população de 228.332 habitantes e uma densidade demográfica de 102,9 hab/ $/ \mathrm{km}^{2}$, enquanto estimativa de 2016, do mesmo órgão, destaca uma população de 279.856 habitantes.

Destarte, com intuito de promover a melhoria da qualidade de vida da população da região; a utilização de forma equilibrada do território, dos recursos naturais e do meio ambiente; um planejamento regional condizente com a realidade; um aproveitamento máximo dos recursos; um melhor desenvolvimento socioeconômico, etc., com base na Constituição de 1988, Art. 25, § 3o, o governo do estado do Tocantins criou a Região Metropolitana de Palmas (RMP). Por meio da Lei Complementar no 90, de 30 de dezembro de 2013, sua criação foi aprovada pela Assembleia Legislativa do Estado e sancionada pelo então Governador Siqueira Campos.

O governo do Tocantins, imbuído do espírito político partidário e por meio de propostas de angariar recursos financeiros para o Estado e para os municípios, fez indicações dos 16 municípios que compõem a RMP, sem estudos prévios e observância dos critérios para delimitação da região de influência da capital regional. Também, sem analisar a sua configuração e seu caráter metropolitano. No que se refere a sua configuração, diz respeito a sua composição, a forma e a organização territorial e espacial, logo, está ligada aos seguintes critérios: à estrutura viária e aos fluxos decorrentes da dinâmica econômica e populacional, as quais redimensionam e interferem consecutivamente nos usos e funções associados ao comércio, aos diferentes tipos de serviços, à indústria e à habitação, conforme estruturação de uma verdadeira região metropolitana (CUNHA, 2017). Quanto ao caráter metropolitano, alude à obediência dos critérios adotados para instituição das regiões metropolitanas, dos quais comprovam a existência ou não de uma região metropolitana.

Neste estudo, não se questiona a legalidade da criação da região metropolitana de Palmas, uma vez que tem amparo legal, pois foi criada com base na Constituição Federal. $\mathrm{O}$ que se questiona neste trabalho é a forma de criação, o processo de institucionalização, bem como os critérios estabelecidos para identificação dos municípios que fazem parte da Região Metropolitana Palmas, assim como, a sua configuração e o seu caráter metropolitano.

Assim, a RMP por ter sido criada antes da aprovação do Estatuto da Metrópole de 2015, pelo Governo Federal e, também, por ainda não ter sido efetivada, conforme pesquisas, faz-se necessário que a sua Lei de criação e seu processo de institucionalização sejam adaptados ao novo Estatuto. Também, devem ser realizados estudos, no sentido de verificar a sua configuração e seu caráter metropolitano, a fim de analisar forma enquanto uma verdadeira região metropolitana e a existência ou não de uma região metropolitana em Palmas. 
Vale lembrar que o Estatuto da Metrópole, em seu Art. 1, estabelece diretrizes gerais para o planejamento, a gestão e a execução das funções públicas de interesses comuns das regiões metropolitanas e em aglomerações urbanas instituídas pelos estados. Também institui as normas gerais sobre o plano de desenvolvimento integrado e outros meios e ações que envolvem a governança interfederativa.

Portanto, devem-se considerar os critérios para identificação, organização e instituição de uma metrópole, estabelecidos no Estatuto da Metrópole que, resumindo, destacam: alta taxa de urbanização; alta densidade demográfica; relações e inter-relações entre a cidade núcleo e os municípios e, entre os próprios municípios, que compõem a região metropolitana, considerando bens e serviços fornecidos pela cidade à região. Entre esses critérios, abrangem-se: produtos industriais, educação, saúde, serviços bancários, comércio empregos, bem como outros itens considerados pelo IBGE e a formação de um núcleo metropolitano ao redor desta cidade.

Trata-se de trabalho que se origina de tese de doutorado. Há uma abordagem teórica sobre região metropolitana, de maneira sucinta, e uma análise das leis concernentes à institucionalização das regiões metropolitanas no Brasil. Enfatiza a discussão sobre processo de institucionalização e a efetivação da Região Metropolitana de Palmas e discute se o caso em exame é uma região metropolitana ou se constitui como uma aglomeração urbana.

Para a coleta de dados, foram realizadas entrevistas semiestruturadas e abertas, com o objetivo de apresentar como se deu o processo de criação, institucionalização e efetivação da Região Metropolitana de Palmas. Também foram realizadas pesquisas em notas taquigráficas (registros) das sessões de votação dos dias que ocorreu a votação da criação da RMP na Assembleia Legislativa do Estado. Ainda formam realizados estudos do Estatuto da Metrópole e em outras fontes bibliográficas, tendo em vista aclarar os conceitos utilizados neste estudo e, principalmente, em relação aos principais critérios de institucionalização das regiões metropolitanas do Brasil. Para realização da pesquisa, foram feitas entrevistas com: três deputados; o ex-governador e um servidor de dos seguintes órgãos: do IBGE; da Secretaria Estadual de Planejamento e Orçamento do Estado (SEPLAN); da Secretaria Estadual de
Infraestrutura, Habitação e Serviços Públicos (SEINF) e da Secretaria Municipal de Desenvolvimento Urbano e Habitação de Palmas (SEDUH).

\section{CONCEITOS DE REGIÃO METROPOLITANA, METRÓPOLE E AGLOMERAÇÃO URBANA}

Primeiramente, vale estabelecer um balizamento que circunscreve as abordagens teóricas sobre região metropolitana, metrópole e aglomeração urbana, uma vez que esses elementos conceituais dão escopo a este trabalho.

Conforme Art. $2^{\circ}, \S \mathrm{VII}$, do Estatuto da Metrópole de 2015, região metropolitana refere-se a "uma aglomeração urbana que configure uma metrópole" (BRASIL, 2015, p. 02).

$\mathrm{Na}$ visão de Matos (2000, p. 1), região metropolitana pressupõe "a existência de uma de uma cidade principal que organiza, econômica e funcionalmente, localidades periféricas próximas". Como consequência, surge uma densa rede urbana onde se instalam diversas atividades industriais, comerciais e de serviço. Assim, concentram capital, força de trabalho e poder político.

Para Moura, Firkowski (2001, p. 112), a região metropolitana alude-se a

[...] uma unidade territorial, polarizada por uma metrópole, definida programaticamente para $\mathrm{O}$ atendimento a objetivos fundamentalmente de ordem políticoadministrativa, executáveis ordenados por modelos de planejamento e gestão que articulem o espaço a políticas públicas.

O conceito de metrópole, referendado no Estatuto da Metrópole, Art. $2^{\circ}$, $\S \mathrm{V}$, identificase como um "espaço urbano com continuidade territorial que, em razão de sua população e relevância política e socioeconômica, tem influência nacional ou sobre uma região que configure, no mínimo, a área de influência de uma capital regional" (BRASIL, 2015 p. 2).

Já Moura e Firkowski (2001, p. 109) conceituam metrópole como uma qualificação dada às "grandes aglomerações urbanas, com milhões de habitantes e capazes de se relacionar economicamente com inúmeras outras cidades, sendo em essência multifuncionais". 
Porém Santos (2001) ressalta que a metrópole é corporativa e fragmentada, compõe-se de espaços luminosos, expressão máxima da modernização e de espaços opaco-periferias, lugares da exclusão dessa modernização.

Sobre aglomeração urbana ou aglomerado urbano, Villaça (2001, p. 52) enfatiza que se refere ao núcleo urbano que "apresenta um mínimo de atividades centrais, sejam religiosas, administrativas, políticas, sociais ou econômicas".

De acordo com Estatuto da Metrópole, aglomeração urbana apresenta-se como "unidade territorial urbana constituída pelo agrupamento de 2 (dois) ou mais municípios limítrofes, caracterizado por complementaridade funcional e integração das dinâmicas geográficas, ambientais, políticas e socioeconômicas" (BRASIL, 2015, p. 1).

Segundo Matos (2000), o conceito de aglomeração urbana no Brasil é relativamente novo. Para o autor, "reporta-se a um conjunto de pessoas ou atividades que se concentram em espaços físicos, relativamente pequenos, daí a sua acepção mais eminentemente urbana, não rural (MATOS, 2000, p. 1). O autor ressalta que esse termo já foi incorporado pelo IBGE em suas pesquisas censitárias e reporta-se a núcleos localizados fora da sede municipal (cidade).

Assim, o conceito de região metropolitana está muito associado ao de metrópole. A região metropolitana identifica-se como uma rede de aglomerados urbanos, na qual a cidade principal e os municípios que a constituem mantêm um fluxo de relações e inter-relações administrativas, econômicas, políticas, sociais com as periferias próximas, a partir das diferentes atividades econômicas desenvolvidas. Assim, identifica-se como uma unidade territorial polarizada por uma metrópole. A metrópole, portanto, é um espaço urbano com continuidade territorial, que mantém diferentes influências, enquanto capital regional. Todavia a aglomeração urbana constitui-se como unidade territorial urbana, formada pelo agrupamento de certos municípios que mantém uma complementaridade funcional e integração das dinâmicas geográficas, ambientais, políticas e socioeconômicas.

\section{CARACTERIZAÇÃO E LOCALIZAÇÃO DA RMP}

A Região Metropolitana de Palmas (RMP) foi instituída por meio da Lei no- 2.824/13, aprovada pela Assembleia Legislativa do Estado e sancionada pelo então governador do estado do Tocantins. A referida Lei, posteriormente, foi corrigida para ordem numérica da Lei Complementar no 90, de 30 de dezembro de 2013, e publicada no Diário Oficial do Estado 꾸 4.042.

De acordo com o Art. $2^{\circ}$ da Lei Complementar no 90, a RMP possui como recorte geográfico espacial a capital, Palmas, e demais municípios que integram a RMP. Ao todo, a RMP é composta de 16 municípios: Aparecida do Rio Negro, Barrolândia, Brejinho de Nazaré, Fátima, Ipueiras, Lajeado, Miracema do Tocantins, Miranorte, Monte do Carmo, Oliveira de Fátima, Paraíso do Tocantins, Porto Nacional, Pugmil, Silvanópolis e Tocantínia.

Também, segundo parágrafo único do Art. $2^{2}$ da referida Lei, integram a RMP os municípios tocantinenses situados entre os paralelos de $11^{\circ} 00^{\prime}$ e 090's cujos interesses sociais, econômicos e políticos convirjam para a metrópole de Palmas. Embora o parágrafo único, do Art. $2^{\circ}$ mencione também os municípios tocantinenses situados entre os paralelos citados acima, esses municípios, até o momento, não fazem parte da RMP, mas futuramente poderão ser inseridos, dependendo dos interesses dos municípios contemplados nesse recorte, bem como da cidade-núcleo, Palmas.

Portanto, atualmente integram a RMP apenas os municípios citados no Art. $2^{2}$, conforme $\begin{array}{llll}\text { apresenta } & \text { a } & \text { Figura } & 1 .\end{array}$ 
Figura 1 - Localização da Região Metropolitana de Palmas

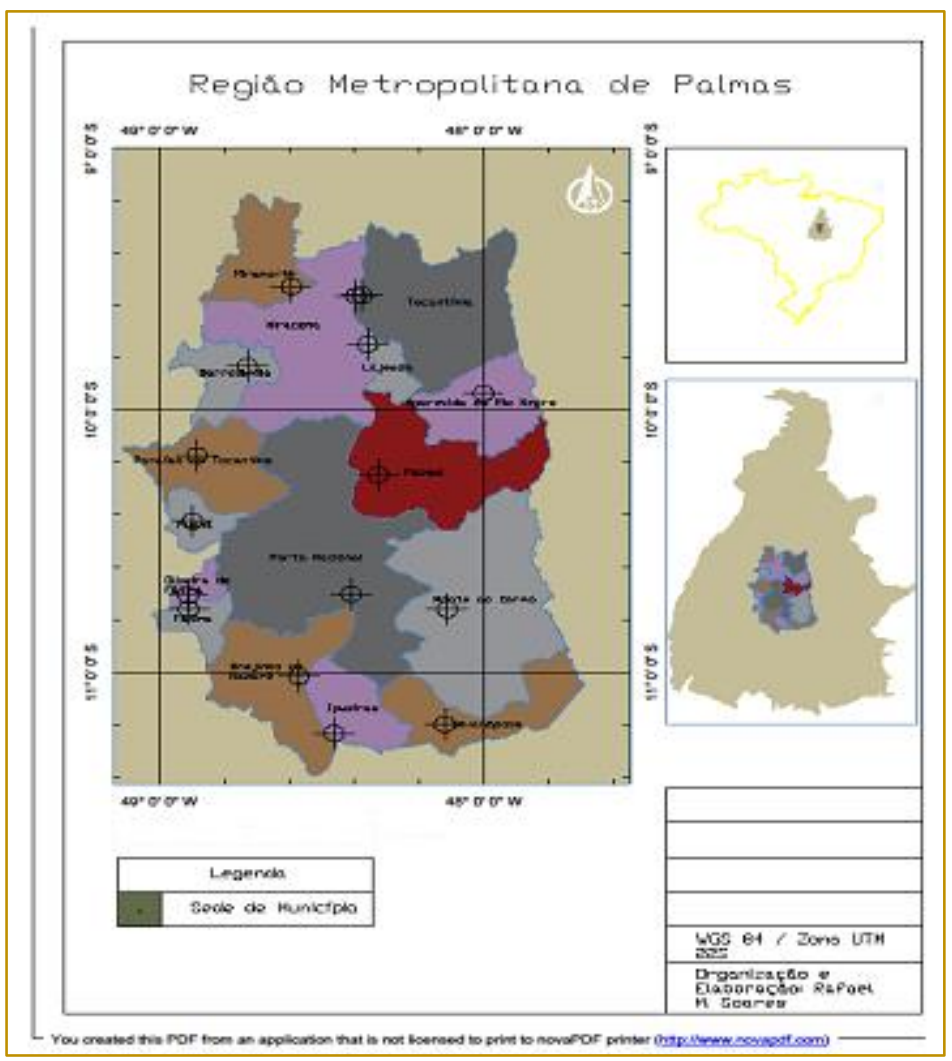

A Lei Complementar no 90, de 2013, encontrase em conformidade com a Constituição de 1988, Art. 25, § 3o, no qual prevê que os "Estados poderão, mediante lei complementar, instituir regiões metropolitanas, aglomerações urbanas e microrregiões, constituídas por agrupamentos de municípios limítrofes, para integrar a organização, o planejamento e a execução de funções públicas de interesse comum" (BRASIL, 1988).

Em conformidade com a Lei Complementar $n^{\circ}$ 90, Art. 3ํㅡ, a organização da RMP tem como objetivo promover: o planejamento regional; a cooperação entre os três níveis de governo, com máximo aproveitamento dos recursos públicos; a utilização equilibrada do território, do pessoal, dos recursos naturais e culturais e a proteção do meio ambiente; a integração do planejamento e da execução das funções públicas de interesse comum; e a redução das desigualdades sociais e regionais.

No que se refere à população dos municípios que compõem a RMP, incluindo Palmas, enquanto município sede, conforme censo demográfico de 2010 e estimativa populacional de 2016 do IBGE apresenta-se de acordo com o quadro de $\mathrm{n}^{\circ} 1$. 
Quadro de ํo 1 - Crescimento da população dos municípios que compõem a RMP

\begin{tabular}{|c|c|c|c|c|c|}
\hline $\begin{array}{c}\text { Cidades que compõem } \\
\text { a RMP conf. } \\
\text { Lei 90, de 30/12/2013 }\end{array}$ & $\begin{array}{l}\text { Censo } \\
\text { pop. de } \\
2010\end{array}$ & $\begin{array}{c}\text { Densidade } \\
\text { dem. de } \\
2010 \text { hab/km² }\end{array}$ & $\begin{array}{l}\text { Estimativa pop } \\
\text { de } 2016\end{array}$ & $\begin{array}{l}\text { Densidade } \\
\text { dem. de } \\
2016 \\
\text { hab/km² }\end{array}$ & $\begin{array}{l}\text { Média do } \\
\text { cresc. } \\
\text { Demog. da } \\
\text { Pop. } 2010 \text { a } \\
2016 \text { em \% }\end{array}$ \\
\hline Palmas & 228.332 & 102,9 & 279.856 & 126,12 & 23,22 \\
\hline $\begin{array}{l}\text { Aparecida do Rio } \\
\text { Negro }\end{array}$ & 4.213 & 3,63 & 4.672 & 4,03 & 0,4 \\
\hline Barrolândia & 5.349 & 7,5 & 5.622 & 7,88 & 0,38 \\
\hline Brejinho de Nazaré & 5.185 & 3,01 & 5.475 & 3,17 & 0,16 \\
\hline Fátima & 3.805 & 9,94 & 3.882 & 10,13 & 0,19 \\
\hline Ipueiras & 1.639 & 2,01 & 1.918 & 2,35 & 0,34 \\
\hline Lajeado & 2.773 & 8,6 & 3.059 & 9,48 & 0,88 \\
\hline Miracema do TO & 20.684 & 7,79 & 19.340 & 7,28 & $-0,51$ \\
\hline Miranorte & 12.623 & 12,24 & 13.363 & 12,95 & 0,71 \\
\hline Monte do Carmo & 6.716 & 1,86 & 7.654 & 2,11 & 0,25 \\
\hline Oliveira de Fátima & 1.037 & 5,04 & 1.104 & 5,36 & 0,32 \\
\hline Paraíso do TO & 44.417 & 35,03 & 49.727 & 39,21 & 4,18 \\
\hline Porto Nacional & 49.146 & 11,04 & 52.510 & 11,80 & 0,76 \\
\hline Pugmil & 2.369 & 5,9 & 2.621 & 6,52 & 0,62 \\
\hline Silvanópolis & 5.068 & 4,03 & 5.372 & 4,26 & 0,23 \\
\hline Tocantínia & 6.736 & 2,59 & 7.387 & 2,83 & 0,24 \\
\hline $\begin{array}{r}\text { Total } \\
\text { Total de hab } \\
\text { Média de }\end{array}$ & $\begin{array}{l}\text { habitante } \\
\text { tes da RI } \\
\text { cimento }\end{array}$ & $\begin{array}{l}\text { da RMP confor } \\
\text {, de acordo co } \\
\text { mográfico da p }\end{array}$ & $\begin{array}{l}\text { e Censo de } 201 \\
\text { estimativa pop. } \\
\text { ulação de } 2010\end{array}$ & $\begin{array}{l}=400.092 \\
2016=46 \\
2016=15\end{array}$ & \\
\hline
\end{tabular}

Fonte: IBGE - Censo Populacional de 2010 e Estimativa 2016. Organizado pelas autoras.

Analisando a Tabela 1, verifica-se que a cidade de Palmas foi a que mais cresceu durante o período de 2010 a 2016. Esse crescimento está associado à criação do Estado em 1988, à sua constituição enquanto capital, ao processo de urbanização, o qual passou o Estado, bem como pela busca da população por um melhor poder econômico e, consequentemente, por melhor qualidade de vida (LIRA, 2011).

Já a cidade de Miracema apresentou, nesse mesmo período, uma taxa negativa de crescimento populacional. Essa cidade foi sede provisória do Governo do Estado, desde a promulgação da Constituição Estadual do Estado do Tocantins, em 5 de outubro de 1989, até a data de 1 de janeiro de 1990, quando ocorreu a transferência da sede do Governo de Miracema do Tocantins para Palmas. Portanto, nesse período a cidade recebeu grande número populacional e também perdeu grande contingente populacional com a estruturação da capital e a transferência dos trabalhadores para a cidade de Palmas.

Quando se analisa o quadro populacional $n^{\circ}$ 1, que apresenta o crescimento populacional dos municípios que compõem a RMP verificase que o mesmo não foi tão significativo, uma vez que em 2010, apresentou-se uma população de 400.092 habitantes e de acordo estimativa de 2016, 463.562 habitantes. Isto significa, que em 6 (seis) anos o crescimento percentual foi de apenas, $15,16 \%$.

Assim, considerando que o processo de metropolização surge da intensificação da urbanização, cujo reflexo de desenvolvimento do núcleo urbano central atinge todos os núcleos a ele articulados. Ainda que, a partir desse processo deva haver uma integração territorial, na qual as diferentes funções de interesses comuns possam ser compartilhados entre os diferentes municípios que compõe a Região. Entende-se que Palmas e os 16 municípios que compõem a região, não se efetivem, realmente, como uma região metropolitana e sim como uma aglomeração urbana.

Nesse contexto, IPEA (2011) justifica que o processo de metropolização deve expressar a concentração de pessoas, investimentos, atividades e poder em uma cidade. 


\section{AS DISCUSSÕES DO PROCESSO DE CRIAÇÃO DA RMP}

Como de praxe, todos os processos de autoria dos deputados e do governador encaminhados para votação na Assembleia Legislativa do Estado do Tocantins devem seguir os mesmos trâmites legais definidos. No entanto não foi o que ocorreu com o Projeto de no 01/2013, que se tratava da criação da Região Metropolitana de Palmas de autoria de um deputado, haja vista que do Setor de Protocolo não foi repassado ao Setor das Comissões para que fosse constituída uma comissão para estudos, discussões e pareceres, seguindo diretamente para Comissão de Constituição, Justiça e Redação (CCJ). Foi indicado o relator do processo, logo em seguida a relatoria repassou ao Procurador Geral para ser avaliado e dar parecer. Após análise, o Procurador Geral, alegando vício de iniciativa ${ }^{22}$, solicitou 0 arquivamento.

Informado desse parecer, o então governador do Estado, em 8 de outubro de 2013, após alterações no projeto, principalmente no que se refere aos municípios indicados para comporem a RMP, deu entrada no protocolo da Assembleia Legislativa de um Projeto de Lei Complementar (PLC), solicitando aprovação para instituir a Região Metropolitana de Palmas, o qual foi registrado pelo Setor de Protocolo com o n-0 06/2013.

Para relatoria do processo na Assembleia, foi nomeado o mesmo deputado que relatou o Processo de no 01/2013 da Comissão de Constituição e Justiça que determinou, por meio de parecer, que o Projeto de Lei 01/2013 da autoria do deputado fosse apensado 06/2013 ao do então governador, ficando o deputado como autor e o então governador como co-autor. Desse modo, foi encaminhado à Procuradoria Geral da Assembleia, a qual recusou o parecer do CCJ, alegando que o PLC 01/2013 pela existência de vício de iniciativa impedia-o de tramitar e, portanto, deveria ser arquivado.

Contudo, no dia 27 de dezembro de 2013, no último dia de sessão legislativa, o Presidente da Assembleia Legislativa, a pedido do então

22 Conforme explicação do Procurador Geral da Assembleia, não possuía elementos legais para ser proposto na forma de Lei na Assembleia, uma vez que seria de competência do Governador do Estado, conforme prevê a Constituição Federal de 1988, Art. 25, § 3ㅇ․ governador, avocou ${ }^{23}$ o processo e, por meio do Art. 180 do Regimento Interno, solicitou a inclusão do PLC 06/2013 na Ordem do Dia da Sessão Extraordinária já solicitada. Nesse sentido, o Presidente da Assembleia justifica que, como Presidente da Casa e por ser uma matéria importante para o desenvolvimento do Estado, a matéria foi evocada, uma vez que o Regimento Interno da Casa o permitia fazê-lo. Assim, o Presidente da Assembleia acatou o pedido em regime de urgência e colocou o Projeto em votação.

O Regimento Interno da Assembleia prevê, em seu Art. 180, do Capítulo II, que os Projetos de Iniciativa do Governo do Estado com solicitação de urgência podem ser incluídos na pauta do dia. Assim, conforme Regimento Interno da Casa, deveriam ser votados em dois turnos, ou seja, em duas sessões.

Conforme registros das notas taquigráficas (registros, gravações), das duas sessões de votação da Assembleia do Tocantins do dia 27 de dezembro de 2013 verificou-se que o projeto foi bastante questionado quanto ao pedido de urgência de votação, pela falta de debate, de diálogo e de entendimento quanto aos critérios e processo para instituição de uma região metropolitana. Embora alguns tenham destacado em seus discursos que: a região metropolitana é uma das melhores que existe; que entendem o benefício que a região metropolitana pode trazer para o Estado; que a criação da Região Metropolitana poderia tirar as prefeituras das dificuldades financeiras e que compreendem a sua importância e a necessidade de criá-la, necessitaria aprofundar os debates e as pesquisas, uma vez que não foi estipulado nenhum critério para seleção dos municípios.

Dessa forma, as duas sessões de votação do dia 27 de dezembro de 2013 instituíram a Região Metropolitana de Palmas Metropalmas, referente ao projeto de lei de $n$ 은 06/2013 de autoria do Governador do Estado. Na reunião da $37^{a}$, na sessão extraordinária 2013/2015, realizada na mesma data, no primeiro turno, de 21 parlamentares presentes, com quorum de maioria absoluta, 15 votaram sim, 2 não e 4 se abstiveram de

23 De acordo com Regimento Interno da Casa avocou, refere-se a uma solicitação feita por meio de Requerimento do Presidente da Assembleia, solicitando a retirada de um processo do arquivo da Assembleia para ser colocado em pauta novamente e ser votado. 
votar. Enquanto que, na $38^{\underline{a}}$ sessão extraordinária do segundo turno, de 18 parlamentares presentes, 14 votaram sim, 2 não e 2 se abstiveram de votar.

Assim, em 30 de dezembro de 2013, foi instituída a RMP por meio da aprovação da Lei $n^{\circ}$ 2.824/2013, pela Assembleia Legislativa do Estado e sancionada pelo então governador do estado do Tocantins. Tendo em vista uma correção para se adequar a ordem numérica, a referida Lei foi alterada para Lei Complementar no 90 e publicada no Diário Oficial do Estado no 4.042, na mesma data.

Nas entrevistas, verificou-se que o interesse pela criação da região surgiu de uma possibilidade viável de valorização do serviço público em prol de seus municípios, vislumbrando a interligação das regiões afins. Principalmente, se implementada, a RMP promoveria a cooperação entre os três níveis de governo, com o máximo aproveitamento de recursos para as áreas de educação, saúde e transporte. Porém, verificou-se ainda que, no ano seguinte da aprovação da Lei, em 2014, seria um ano político/eleitoral, uma vez que haveria eleições para governadores, senadores, deputados estaduais e federais e que, mais especificamente no segundo semestre, iniciariam as campanhas eleitorais que, de certa forma, justificavam a urgência da aprovação da Lei Complementar no 90/2013, a qual instituía a RMP.

\section{DOS CRITÉRIOS E PROCESSO DE CRIAÇÃO, EFETIVAÇÃO E INSTITUCIONALIZAÇÃO DA RMP}

Tendo como referência as falas dos entrevistados, o processo de criação foi realizado com base Constituição Federal, a qual prioriza aos estados a criação da região metropolitana. O processo de criação apresentou-se de forma tumultuada, uma vez que as questões políticas permearam todas as discussões. Conforme descrições, o processo de criação refere-se a uma iniciativa de um deputado da Assembleia que foi julgado como vício de iniciativa e depois, a partir do mesmo projeto, com algumas alterações, no que tange à relação dos municípios que integravam a região, o então Governador, por meio da exclusão e inclusões de outros, conforme interesses dos administradores dos municípios e partidos políticos, fez alterações e foi aprovada a criação da RMP. Devido à urgência de aprovação do Projeto de Lei, muitos deputados questionaram a falta de estudos no que tange aos critérios de definição de uma região metropolitana, questões socioeconômicas e ambientais, também da falta de discussões sobre o projeto e a necessidade de realizá-las, haja vista a importância e a grandeza do projeto.

No que se refere aos critérios de escolhas utilizados para selecionar os municípios da RMP, conforme respostas obtidas, os municípios foram selecionados por meio de um levantamento das necessidades comuns e a parceria em busca de recursos públicos para melhorar a qualidade de vida de seus moradores. Assim, foram adotados critérios técnicos que identificam os interesses dos gestores municipais pela busca de recursos públicos para investir em cada município, as relações políticas e suas necessidades financeiras. Também registraram que a caracterização dos municípios selecionados para compor a RMP teve como base os dados publicados pelo SEPLA, pelo IBGE e por outros órgãos. Ainda se verificou nas falas que um dos principais critérios utilizados para seleção foi a aproximação das áreas, especialmente as áreas limítrofes de cada município.

Assim, nota-se a ausência de adoção de critérios de seleção para a escolha dos municípios que integraram a RMP, apresentando, de forma visível, que foram os critérios políticos que intermediaram a escolha dos municípios para integrarem a RMP. Não foram destacadas, em nenhum momento, a formação de núcleo urbano e a complementaridade funcional e ou a integração entre a capital Palmas e os municípios e entre os próprios municípios que fazem parte da RMP.

No que diz respeito aos estudos que comprovem as relações de interdependência, por meio da prestação de diferentes serviços, como educação, saúde, transporte, comércio etc., entre a metrópole e os municípios que integram a RMP, de acordo com os entrevistados, há uma relação de interdependência entre os municípios que integram a RMP, uma vez que seus moradores procuram a metrópole de Palmas para obtenção de diversos serviços públicos.

Sobre existência de uma região metropolitana em Palmas, para muitos, as relações entre os municípios e a metrópole são visíveis diante da procura dos municípios pelos diferentes 
serviços em Palmas. No entanto alguns entrevistados consideram que o processo de metropolização encontra-se em fase de desenvolvimento, enquanto outros ainda não visualizaram a existência de uma metrópole, mas acreditam que ela ainda pode apresentar.

Quanto à existência de uma complementaridade funcional e a formação de uma aglomeração urbana/núcleo metropolitano no entorno da cidade de Palmas-TO, alguns entrevistados confirmaram a existência em face da grande quantidade de serviços que são oferecidos pela capital aos municípios que integram a RMP. Outros ressaltam a necessidade de realizar pesquisas e estudos para essa comprovação, uma vez que não foram feitos.

Tendo em vista as respostas obtidas e a falta de acesso aos relatórios dos estudos realizados, conforme descrição de alguns, explicitados mediante tempo decorrido, verificou-se a falta de entendimento desses critérios, principalmente em relação à seleção dos municípios, uma vez que muitos descrevem sobre a necessidade de estudos para comprovação da existência ou não dos referidos critérios. Enquanto que para outros esses critérios estão visíveis, quando da procura da população pelos serviços oferecidos em Palmas. Assim, nota-se a não realização desses estudos, embora não fique comprovado.

No que tange às ações que foram desenvolvidas para efetivação da RMP e dos benefícios a serem recebidos com a efetivação, de acordo com os entrevistados, não se comprova a realização de ações para efetivação da RPM, visto que essas ações são de responsabilidade tanto do Estado, como dos municípios. No que se refere aos benefícios, os entrevistados apontam que são vários. Os principais são a realização de um planejamento regional, cooperação entre as três esferas de governo (municipal, estadual e federal), visando ao aproveitamento dos recursos públicos e à utilização equilibrada do território, ou seja, toda a região do estado do Tocantins será beneficiada por meio de recursos financeiros que serão disponibilizados.

A partir das descrições das falas, identifica-se que o processo de criação da RMP foi realizado com base na abertura dada pela Constituição Federal de 1988, a qual prevê, mediante lei complementar, instituir regiões metropolitanas, aglomerações urbanas e microrregiões por meio do Art. 25, $\S 3$ ㅇ. Portanto, a RMP é legítima, uma vez que está assegurado esse direito aos estados.

No entanto nota-se a falta de conhecimento dos critérios a serem adotados para identificação e reconhecimento da existência de uma Região Metropolitana em Palmas. Os critérios para a seleção da região de influência de uma capital regional devem apresentar, por meio de estudos, comprovações de um espaço urbano com continuidade territorial, em razão de sua população e relevância política e socioeconômica, considerando bens e serviços fornecidos pela cidade à região, como produtos industriais, educação, saúde, comércio, serviços bancários, transporte etc. Enfim, o processo de institucionalização da RMP deve adequar-se ao Estatuto da Metrópole, assim como deve fazer uma revisão na Lei Complementar de $\mathrm{n}^{\circ}$ 90, de 2013, a qual institui a RMP.

\section{CONSIDERAÇÕES FINAIS}

Numa perspectiva analítico-dialética, quando são analisadas as ações políticas edificadas em um território e, especialmente as vivenciadas em Palmas Tocantins, é necessário reviver os conceitos de Brito (2002, p. 12) sobre o território quando afirma que é uma fração do espaço na qual "determinados agentes sociais se relacionam com o intuito de reproduzi-lo segundo seus próprios interesses (condição que manifesta o uso do território), mediante consensos estabelecidos tácita e/ou formalmente".

Embora não defina, como via de regra, as ações políticas de poder, nem tão pouco como uma coalizão de forças de interesse comum, explícito e pré-planejado, poderão aparecer como primeiros sinais de configuração no território, como um tipo de mercadoria, dominada pela força do poder, a partir das formas de processos de gestão, mediados pelas relações políticas com os agentes sociais, tendo em vista a reprodução de interesses de ambas as partes.

Assim, identifica-se que, quando se trata de um território mediado pelas relações de poder político com diferentes agentes sociais, refere-se a um fenômeno intrínseco das relações sociais, sem violência, vinculado à disciplina e à livre adesão dos atores sociais. Dessa maneira, o poder necessita da 
legitimidade dos agentes, de uma permissão para agir "em nome do consenso", em nome da união. Assim, quando se diz que alguém está no poder, explica Arendt (1994), na realidade, refere-se ao fato de que ele foi empossado por certo número de pessoas para agir em seu nome. O poder aqui referendado reside não na vontade individual, mas na vontade coletiva.

Daí surge o seguinte questionamento: quem são os atores público-políticos que são indicados para gerir os espaços de poder em prol do bem comum? Que lutam a favor da melhoria dos espaços urbanos com igualdade de direitos e deveres? Que pensam no uso coletivo e não no individual? Que, independentemente de partidos políticos, procuram planejar e estabelecer diretrizes gerais, pensando em proporcionar atendimento às necessidades básicas da população, que atualmente se encontra à mercê dos seus direitos?

Assim, reforça-se a necessidade de outras sustentabilidades que permeiam as decisões das políticas territoriais, uma vez que a garantia do sucesso de qualquer ação política está vinculada ao resultado da responsabilização dos que recebem o poder de gerir os espaços territoriais. A sociedade carece de justiça social, principalmente de benefícios que dão sustentabilidade nos espaços territoriais.

Nesse sentido, Garson (2009) chama atenção da existência de uma grande inabilidade no trato político e institucional no país, que é provocada pelas falhas apresentadas na legislação, principalmente quando se consideram as disparidades territoriais encontradas na gestão de uma região metropolitana.

Quando se analisam os termos Constituição Federal (BRASIL, 1988), do Art. 25, § 3으, é possível prever que cabe ao Estado, por meio de lei complementar, instituir regiões metropolitanas, aglomerações urbanas e microrregiões, formadas por agrupamentos de municípios limítrofes, para integrar a organização, o planejamento e a execução de funções públicas de interesse comum. Dessa maneira, não apresenta nenhuma referência ou órgão que deva legislar e estabelecer critérios específicos sobre a criação das regiões metropolitanas no Brasil.

Nesse sentido, as falhas apresentadas na legislação, no que se refere à criação de regiões metropolitanas, quando deixa a cargo dos estados essa prerrogativa, que se materializa, mediante aprovação de lei complementar estadual, oferecem abertura para a criação de grande número de regiões metropolitanas pelos governos estaduais, que muitas vezes nem se caracterizam como tal, e acima de tudo sem a mínima condição de serem implementadas e efetivadas. Isso se deve à falta de observância das diretrizes gerais da política urbana, especialmente da inobservância de critérios consistentes quanto ao número da população a ser atendida; o grau de urbanização; os bens e serviços prestados; as relações e interações existentes entre a metrópole e os municípios e entre próprios municípios e a caracterização da centralidade regional. Elementos esses que, deveriam ser observados ao caracterizar essas unidades regionais, e não os fatores políticos, ao planejar instituir as regiões metropolitanas. Daí surge à necessidade de se estabelecerem parâmetros legais para a criação das regiões metropolitanas e de aglomerações urbanas.

Ao analisar os debates em plenária, por meio das notas taquigráficas e das falas dos entrevistados, fica evidente que a RMP foi instituída a partir de discussões políticas e que não foram feitos estudos tanto de caracterização dos municípios, quanto das interações entre os municípios. Quando solicitados os estudos para análise, não são apresentados, haja vista a existência do tempo transcorrido. Portanto, na prática, o que ficou comprovado é que a RMP apenas foi instituída, que os critérios adotados para sua institucionalização não ficaram visíveis e que apenas uma ação foi desenvolvida, confirmando, assim, que não foi efetivada.

Os estudos, a partir desse momento, deverão ser realizados no sentido de responder aos seguintes questionamentos: como se apresenta a configuração da RMP, enquanto aglomeração urbana ou como região metropolitana? de acordo com os critérios utilizados para institucionalização das regiões metropolitanas do Brasil, a RMP possui um caráter metropolitano ou não? Palmas, capital do estado do Tocantins pode ser considerada uma metrópole ou não? Existe em Palmas uma região metropolitana ou não?

Caso os estudos não comprovem esses questionamentos, então devem ser direcionados para uma visão de uma aglomeração urbana em Palmas e não uma Região Metropolitana. 


\section{REFERÊNCIAS}

[1] Arendt, H. Sobre a violência. Tradução André Duarte. Rio de Janeiro: Relume-Dumará, 1994.

[2] Brasil. Constituição Federal. Brasília: Congresso Nacional, 1988.

[3] Lei no 13.089. Estatuto da Metrópole. Presidente da República, em 10 de janeiro de 2015.

[4] Cunha, Débora Ferreira da. Instituição da Região Metropolitana de Goiânia - Goiás (19802010): configuração e interações espaciais entre os municípios. Tese (Doutorado) Universidade Federal de Goiás, Instituto de Estudos Socioambientais (IESA), Programa de Pós-Graduação em Geografia, Goiânia, 2017.

[5] Brito, C. C. T. Revisitando o conceito de território. Revista de Desenvolvimento Econômico, Salvador, n. 6, p. 12-20, jul. 2002.

[6] Garson, S. Regiões metropolitanas: por que não cooperam? São Paulo: Letra Capital, 2009. [7] Ibge. Censo Pop. 2010 e Estimativa 2016. Disponível em: https://cidades.ibge.gov.br/v4/brasil/to/barrolandia/ panorama. Acesso em: 24 out. 2016

[8] Lecioni, Sandra. A metrópole de São Paulo: o anúncio de um novo mundo de aglomerações difusas. Revista Paranaense de Desenvolvimento, Curitiba n. 120, p. 133-148, jan./jun. 2011

[9] lira, E. R. A gênese de Palmas - Tocantins: a geopolítica de (re)ocupação territorial na Amazônia Legal. Goiânia: Kelps, 2011.

[10] Matos, R. Aglomerações urbanas, rede de cidades e desconcentração demográfica no Brasil. $2000 . \quad$ Disponivel em: <http://www.abep.nepo.unicamp.br/docs/anais/pdf/ 2000/Todos/migt4_3.pdf>. Acesso em: 24 out. 2016.

[11] Moura, R.; Firkowski, O. L. C. de F. Metrópoles e regiões metropolitanas: o que isso tem em comum? Anais: Encontros Nacionais da ANPUR, v. 9, 2001.

[12] Santos, M. A urbanização brasileira. 5. ed. São Paulo: Edusp, 2001.

[13] Tocantins. Lei de $n^{-}$90, de 30 de dezembro 2013. Institui a Região Metropolitana de Palmas.

[14] Villaça, F. Espaço intra-urbano no Brasil. São Paulo: Nobel, 2001. 


\section{Bapítulo 4}

\section{RELAÇÕES DE USOS E CONSUMOS DE ESPAÇOS PÚBLICOS DE LAZER E TURISMO NA CIDADE DE ARACAJU/SE}

\section{Cristiane Alcântara de Jesus Santos Larissa Prado Rodrigues}

Resumo: Situados em uma relação dialética, as formas de produção e consumo se realizam e concretizam indissociavelmente no e a partir do espaço, permeadas por inúmeras e complexas contradições. Deste modo, os espaços públicos urbanos, em meio aos processos supracitados impulsionados pela hegemonia do capital, estão imersos em inúmeros paradoxos, conflitos e tensões latentes que devem ser explicitados em suas especificidades, com vistas à superação de problemáticas que transformam a vida nas cidades em privação mediante a crise urbana instaurada. Diante desse contexto, o presente artigo tem por objetivo identificar e analisar as relações de usos e consumos denotados aos espaços públicos de lazer e turismo, atendo-se, especificamente, aos parques públicos da cidade de Aracaju, Sergipe, Brasil, a partir das suas dinâmicas sócio-espaciais. Para isto, utilizamos a metodologia baseada na pesquisa quanti-qualitativa que incluiu o levantamento bibliográfico, pesquisas de campo com aplicação de questionários estruturados, e observações diretas e netnográficas. Em análise comparativa, averiguou-se que as dinâmicas dos espaços públicos são distintas, até mesmo em equipamentos que apresentam fins similares e estão alocados na mesma cidade, como é o caso dos parques investigados, de modo que o fator localização incide significativamente sobre as configurações destes últimos.

Palavras-Chave: Parques Públicos. Usos. Consumo. Lazer. Turismo. 


\section{INTRODUÇÃO}

Os parques públicos são equipamentos que compõem o contexto de produção e consumo do espaço urbano contemporâneo. Deste modo, são elementos que estão imersos tanto na paisagem, quanto na dinâmica urbana. Os mesmos possuem origem na busca e anseio do homem urbano pelo refúgio, pelas características do campo, pelo retorno e (re) encontro com a natureza (GOMES, 2013).

Neste sentido, os parques públicos apresentam grande importância social, uma vez que são entendidos como espaços com acesso livre para práticas de lazer em meio ao cenário urbano. Estes equipamentos proporcionam àqueles que os visitam a aproximação com a natureza, a prática de atividades físicas e de sociabilização, tidos pelos usuários como uma forma eficaz, mesmo que temporária, de fuga dos males da modernidade que assola a vida cotidiana citadina que, na contemporaneidade, se caracteriza pela exacerbação de privações.

Concomitantemente, são espaços com grande potencial para as práticas turísticas, tendo em vista que os turistas podem conhecer novos espaços de lazer que caracterizam e revelam aspectos identitários de destinos turísticos. Entretanto, na realidade da cidade de Aracaju, capital do estado de Sergipe, localizada na região nordeste do Brasil, há a problemática instaurada no fato de que a maioria dos parques públicos não apresenta visitação por parte dessa demanda por diversos fatores, caracterizando uma forma de não uso desses espaços, neste caso, pela atividade turística.

No âmbito do lazer, emergem as questões acerca dos recortes de uso dos parques públicos pelos moradores da localidade, uma vez que surge a problemática da apropriação dos espaços públicos de, para e por todos, intrinsicamente relacionado à ausência do direito à cidade aos cidadãos. Isto porque apesar dos espaços públicos serem entendidos constitucionalmente como de/para todos os cidadãos, valores sociais e morais se impõem sobre a forma de uso desses espaços, fruto da racionalidade advinda e imposta pela lógica do consumo.

Assim, no momento em que indivíduos ou grupos sociais rompem com os usos programados e destinados para os equipamentos públicos, rapidamente são apontados como geradores de contra-usos (LEITE, 2007). A partir disso, inúmeros conflitos e disputas se estabelecem no espaço urbano, fortalecendo as relações de poder e incentivando, por exemplo, a prática de políticas higienistas com vistas a potencializar o valor de troca sobre esses espaços mediante a estipulação do valor de uso.

Levando-se em consideração as presunções supracitadas, torna-se de suma importância analisar as dinâmicas sócio-espaciais dos parques públicos na tentativa de contribuir para a minimização de problemáticas, a fim de que estes possam resultar em espaços públicos, de fato, democráticos, sendo utilizado e apropriado tanto por moradores, quanto por turistas, com aproveitamento máximo de sua infraestrutura custeada com recursos públicos.

Neste sentido, este artigo tem por objetivo identificar e analisar as relações e formas de usos e consumos denotados aos espaços públicos de lazer e turismo, atendo-se, especificamente, aos parques públicos da cidade de Aracaju/SE, a partir das suas dinâmicas sócio-espaciais. Com isso, visamos compreender e explicitar os usos, não usos e contra-usos existentes e configurados no Parque da Sementeira e no Parque da Cidade, a fim de perceber contradições, (des) semelhanças e identificar os fluxos que se destinam para esses espaços públicos urbanos. Os dois parques estão localizados em zonas distintas e antagônicas da cidade (FIGURA 1), fator que exerce grande influência no que tange às relações que são estabelecidas no interior dos parques assim como nos espaços circunvizinhos. 
Figura 1: Aracaju - Localização da área de estudo

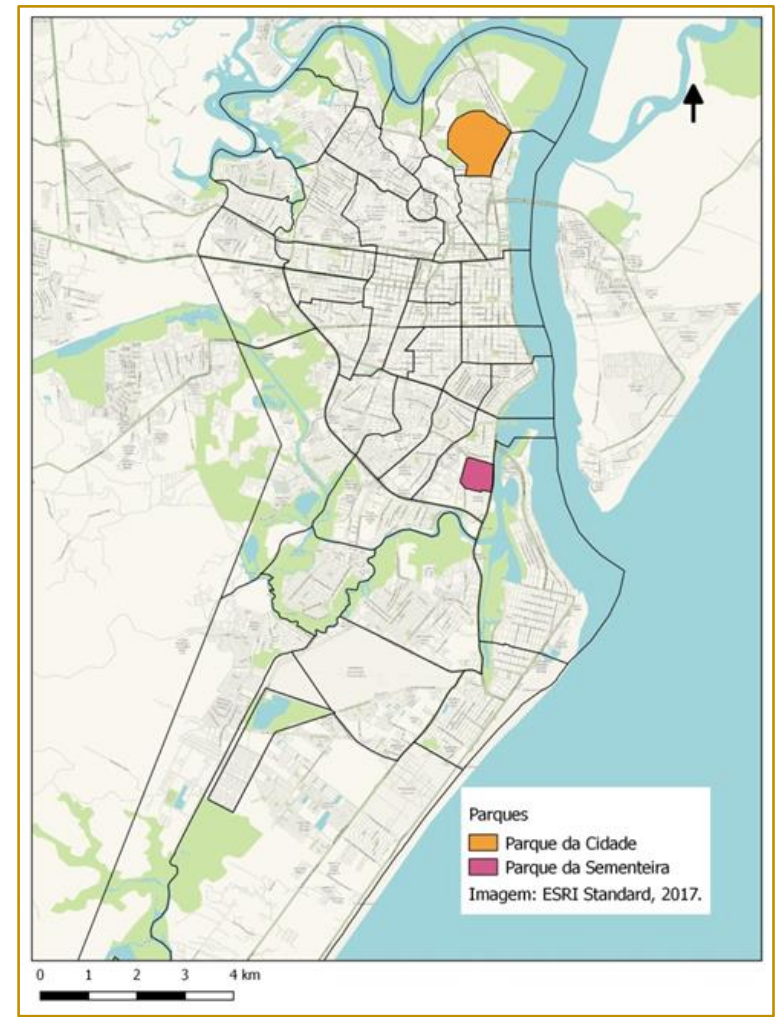

Fonte: EMURB/PMA. Atlas SRH/SE, 2016;

Elaboração: As autoras, 2018.

Considerando as complexidades envoltas aos processos de produção e consumo dos espaços públicos das cidades contemporâneas, bem como mediante os objetivos estabelecidos, elegeu-se como procedimentos metodológicos a pesquisa quanti-qualitativa e do tipo exploratória. A princípio realizou-se 0 levantamento bibliográfico acerca dos espaços públicos com ênfase nos parques urbanos.

Posteriormente, foram realizadas pesquisas de campo nos objetos de estudo, propondo uma análise a partir da observação direta dos usos, não usos, contra-usos e potencialidades de consumo. Ainda, foram aplicados in loco questionários estruturados para moradores e turistas. Designaram-se 100 questionários para serem aplicados em cada parque investigado, sendo 50 destinados ao público morador e 50 ao público turista; entendendose que esse quantitativo traria resultados diversificados para o desenvolvimento das análises necessárias e, portanto, a elucidação da problemática de pesquisa.

Também foi realizada, a partir da observação netnográfica, a análise no site TripAdvisor de avaliações realizadas pelos usuários-turistas acerca dos parques públicos, visando a coleta de dados que tornassem possível identificar os usos manifestados por estes indivíduos durante a visitação aos equipamentos investigados. Em suma, tais procedimentos foram de fundamental importância para verificar as formas de usos, não usos e contra-usos dos dois parques públicos, tanto no âmbito das práticas turísticas, como na rotina e práticas de lazer dos cidadãos aracajuanos.

\section{OS PROCESSOS DE PRODUÇÃO E CONSUMO DOS PARQUES PÚBLICOS URBANOS: BREVES DISCUSSÕES}

Historicamente, os parques públicos remetem à Antiguidade. No decorrer dos anos, estes ganharam novas dimensões e significados oriundos da Idade Média até estabeleceremse na era e cidade moderna. Contudo, os aspectos de proporcionar lazer, contato com a natureza e a representação de poder sempre estiveram presentes (GOMES, 2013). Quando criados, os parques tinham o propósito de embelezar os espaços das cidades, proporcionar qualidade de vida e lazer para a aristocracia, embora em concepções distintas das difundidas atualmente pela sociedade moderna. Capel (2002, p. 5) menciona que até o século XVIII, 
os jardins e parques públicos eram "paraísos privados, construídos pela realeza, aristocracia e, mais tarde, a burguesa para seu uso particular. Lugares para o descanso e o retiro deleitoso, para a alegria privada e o jogo amistoso, para a ostentação e o repouso".

Após décadas e com o fim do feudalismo, os parques públicos passaram a receber influências da era da produção capitalista e, por conseguinte, da supervalorização da propriedade privada e outros valores intrínsecos. Somente em meados do século XVIII se tornaram espaços públicos a serem utilizados coletivamente. Assim, posteriormente à revolução industrial, os parques públicos passaram a ter grande importância social quando os trabalhadores em meio ao espaço urbano buscam o lazer, a qualidade de vida e satisfação, pois a rotina laboral de cunho altamente exploratório nas indústrias originou uma série de problemas psíquicos em decorrência do trabalho incessante nas fábricas.

Sob esse prisma, Melo e Dias (2012, p. 7) ressaltam que os parques públicos tornaramse "importantes para a qualidade de vida das pessoas, preservação da natureza, história da vida cotidiana, configuração espacial e influenciam na estrutura urbana das grandes cidades". Neste mesmo sentido, Gomes (2013, p. 62) afirma que o parque público na atualidade "é um produto da cidade moderna. Constitui uma reação aos desprazeres da cidade, aos 'males' e às precárias condições de vida comuns à cidade industrial". Deste modo, os parques públicos são espaços de lazer, sociabilidade e/ou preservação ambiental constituintes da paisagem urbana que se encontram em meio às características, elementos, funções, configurações, processos, paradoxos, conflitos, contradições e também das complicações e crises das cidades contemporâneas.

Pelo viés preservacionista, os parques públicos constituem-se em espaços de preservação ambiental, de proteção à natureza "pura", de forma a introduzir as tendências de uso racional dos recursos naturais, como a partir de práticas de educação ambiental. Especialmente no final do século XVIII, surgem ideais de retorno e valorização a áreas de natureza verde devido à grande exploração do espaço para a concretização e expansão dos processos de urbanização, tornando a paisagem cinzenta. Em locais já explorados, os parques surgiram como um modo de retratar a natureza em meio às cidades, mesmo que de forma artificial e espetacularizada, portanto, espaços verdes repletos de representações urbanísticas, constituindo um substituto medíocre da natureza, ou seja, simulacros degradados do espaço livre (LEFEBVRE, 2008a), na tentativa de se contrapor ao cenário urbano.

A partir da lógica capitalista associada aos movimentos de urbanização engendrados no século XVIII, os parques públicos tornaram-se elementos de valorização da terra, sendo justificativa e estratégia da especulação imobiliária para o aumento do valor de imóveis nas proximidades desses espaços verdes de encontro à natureza, constituindo os bairros de status (GOMES, 2013). Automaticamente, esses espaços acabam por ter seus usos apropriados por aqueles que residem nas proximidades, ou seja, por classes dotadas de maior poder de compra (e troca) e que acabam por possuírem maior acessibilidade. Sob essa perspectiva,

Os parques são elementos da paisagem urbana que se inscrevem no espaço construído. Ocupam área especifica, demarcada no espaço, sobre a qual se realiza trabalho, obras que permitem o seu uso efetivo. Este trabalho, obras, altera a característica do lugar, espaço onde está inserido. [...] No entanto, dependendo da localização, são apropriados privadamente por classes e interesses específicos (GOMES, 2013, p.61).

Por conseguinte, os parques urbanos públicos estão, em sua maioria, implantados em locais específicos das cidades e raramente abrangem periferias, subúrbios e locais de população de baixa renda. Diferentemente dos espaços públicos das regiões menos valorizadas pelos agentes do capital, os parques públicos inseridos e/ou cercados por áreas privilegiadas recebem constantemente assistência pelo Estado no que concerne a investimentos para manutenção do seu interior. Isso demonstra para onde se direcionam os fluxos de investimentos públicos, apontando que existe uma arbitrariedade excludente na produção e organização espacial das cidades para o lazer. Como consequência, a segregação sócio-espacial é gerada juntamente com a ausência do direito ao lazer para os moradores de regiões menos favorecidas. No entanto, a contradição emerge no ponto em que estes moradores contribuem igualmente 
com impostos e não possuem direito às benesses e à cidade que "pagam" para morar.

Desta forma, devido ao fato da produção do espaço ser fundamentada em um processo desigual, "O urbano se apresenta, ao contrário, como lugar dos enfrentamentos e confrontações, unidade das contradições. É nesse sentido que seu conceito retoma o pensamento dialético [...]" (LEFEBVRE, 2008b, p. 157), considerando que a (re) produção espacial atual e impacta diretamente nos usos destinados e configurados que perpetuam a injustiça espacial, sendo, deste modo, a produção e consumo indissociáveis, bem como situados em uma relação dialética. Diante disso, podese auferir que os parques são elementos que influenciam na produção do espaço, e por esta são influenciados, traduzindo-se os impactos na forma e momento de uso e consumo.

Após o processo conflituoso, contraditório, desigual e de segregação na produção do espaço urbano, este enquanto mercadoria é posto ao consumo dos indivíduos que podem ter acesso às porções produzidas, levando à constatação de que "as cidades são criadas para a economia e não para os cidadãos" (SANTOS, 1997, p. 48). Assim, adentramos, nesse momento, na perspectiva do espaçomercadoria, em que o espaço urbano é colocado à venda nas "prateleiras", sobretudo, do mercado imobiliário. As cidades passam a ser vendidas sob o slogan do crescimento e, mais recentemente, do desenvolvimento sustentável, visando em realidade, favorecer os processos da acumulação do capital, no qual "isso significa dizer que o espaço torna-se mercadoria, entra no circuito da troca, e com isso espaços antes desocupados se transformam em mercadoria, entrando na esfera da comercialização" (CARLOS, 1999, p. 175).

Neste contexto, parte-se da perspectiva do espaço de consumo - enquanto o pedaço da terra que favorece a produção, distribuição, circulação, troca e consumo de mercadorias para o consumo do espaço - em que os fragmentos deste são submetidos constantemente às especulações de compra e venda para a reprodução da vida, tanto no âmbito das atividades laborais, quanto nas práticas de lazer (CARLOS, 1999). Assim, podemos afirmar que estes espaços são apropriados, dominados e controlados pelos agentes promotores imobiliários, atendendo às regras do jogo e mercado imobiliário por meio do alicerce das políticas estratégicas e coniventes do Estado, que negligenciam setores e esferas de demasiada importância na sociedade para prestar assistência aos lobbys, cada vez mais recorrente no âmbito da proposição e execução da política pública brasileira.

Deste modo, o modo de consumo das áreas produzidas no espaço urbano é refletido no uso que se torna cada vez mais privativo dado às forças do mercado que transfere a propriedade do espaço urbano à demanda solvável, uma vez que esta demanda pode arcar com os custos propostos no valor de troca e do valor de uso no que concerne às manutenções. Em resumo, "o espaçomercadoria, cada vez mais preso no universo da troca, fragmentado pelo processo de compra e venda, impõe importantes transformações no plano do uso e do consumo do espaço" (CARLOS, 1999, p. 176), com predominante segregação no acesso do espaço urbano a determinadas classes, refletindo em aspectos de moradia, saúde e lazer das populações mais pobres, postas à margem dos processos desenvolvimentistas e, mais que isso, das centralidades e funcionalidades das cidades.

Neste problemático contexto, os parques públicos tornaram-se locais propiciadores de recreação, bem-estar, qualidade de vida e de satisfação àqueles que o frequentam. Dentre suas possibilidades de usos no momento do consumo a partir da perspectiva contemporânea, podem-se destacar as práticas de atividades esportivas e de lazer (caminhadas, cooper, futebol, skate, patins, ciclismo); atividades lúdicas (em playgrounds, em espaços livres: jogos, brincadeiras, danças, contemplação, encontros, leitura); alimentação (lanches, feiras, bares, lanchonetes, e mais recentemente food trucks); consumo de elementos paisagísticos (arborização, o verde, flores, gramados, lagos e lagoas); consumo de elementos arquitetônicos e urbanísticos (monumentos, quiosques, iluminação, pontes, espelhos d'água, sanitários, bancos, lixeiras); com segurança e manutenção (espaços seguros, tranquilidade, guardiões, zeladores, policiamento) e/ou atividades culturais (eventos, peças de teatro ao ar livre, movimentos, práticas religiosas, festividades) (LOBODA, 2009).

Mediante as possibilidades supracitadas de utilização desses espaços tidos como 
parques públicos das cidades, torna-se possível pensar sua apropriação não apenas por moradores/residentes, mas também por turistas que estejam em visitação à localidade. Os parques públicos, além de propiciar lazer aos seus cidadãos, "também pode cumprir um papel de atrair turistas, contribuindo para a valorização da paisagem, melhoria da infraestrutura e da qualidade de vida" (LAPA et.al., 2010, p. 37). Contudo, esses espaços públicos de lazer ainda são, em sua maioria, desconsiderados como constituintes da oferta turística de uma localidade, o que caracteriza o não uso desses espaços pelos turistas por diversos fatores.

Para o turismo, os parques públicos se destacam por oferecer atratividades relacionadas à paisagem, manifestações culturais, historicidade, arquitetura e atividades lúdicas, características que são enfatizadas e estão presentes nos elementos constituintes da oferta turística. Com isso, o turista ao visitar os parques públicos de uma localidade pode experienciar e vivenciar não somente momentos de lazer e recreação, mas também passar por processos de aprendizagem ao apreciar a natureza diferenciada do seu local de origem, além dos fatores relacionados aos aspectos sóciohistórico-culturais.

De mesmo modo, ao se deparar com a forma como os parques públicos urbanos estão estruturados, o turista pode (re) conhecer o modo de vida e cultura da localidade através das manifestações culturais, dos elementos históricos e arquitetônicos, e as atividades lúdicas que compõem esses equipamentos, o que contribui para apontar e reforçar a identidade local, a fim de tornar a experiência e vivência dessa demanda mais rica dentro da cidade e do contexto do destino turístico, auxiliando na criação e/ou fortalecimento da imagem do mesmo.

Neste sentido, a função turística exercida pelos parques públicos urbanos já é realidade em muitos destinos turísticos. Em escala internacional, o Central Park, nos Estados Unidos, é sobremaneira salientado enquanto um dos parques urbanos mais visitados em todo o mundo. Entre as cidades brasileiras se destacam Curitiba, capital do estado de Paraná, com os Parques Tanguá, Tingui e Barigui, alvos de forte estratégia de promoção turística; e São Paulo, com o Parque do Ibirapuera, consolidado atrativo turístico.
Em outras cidades, a exemplo da capital Aracaju, o não uso desses espaços pelos turistas está associado a deficiente divulgação dos parques públicos, assim como a não inserção desses equipamentos nos roteiros turísticos locais, principalmente nos cities tours ofertados pelas agências de turismo receptivo (RODRIGUES; SANTOS, 2018). Ainda, torna-se importante ressaltar a influência do guia de turismo na não visitação desses espaços, tendo em vista que são profissionais que guiam e encaminham os visitantes aos atrativos turísticos. Desta forma, o turista opta e/ou é direcionado a visitar os principais atrativos da cidade e os parques públicos acabam não sendo considerados atrativos turísticos primários.

\section{CONSUMOS, USOS, NÃO USOS E CONTRA-USOS DOS PARQUES PÚBLICOS DE ARACAJU/SE}

A partir de intervenções urbanas realizadas na cidade de Aracaju, os parques públicos emergiram e consolidaram-se. Diante das problemáticas anteriormente citadas, esses espaços públicos de lazer e turismo devem ter seus usos e apropriações analisados e discutidos tendo em vista que, apesar de serem bens públicos e de usufruto dos cidadãos aracajuanos, em alguns casos são direcionados indiretamente às classes de maior poder aquisitivo em razão de acessibilidade em caráter de exclusividade, fruto de processos de especulação imobiliária engendrada que geram impactos demasiados sobre o caráter público desses espaços.

Além disso, ao vislumbrarmos as alternativas de usos desses espaços, torna-se possível pensar sua apropriação não apenas por residentes, mas também por turistas que estejam em visitação à localidade. Diante de atratividades relacionadas à paisagem, aspectos sócio-histórico-culturais e atividades lúdicas nesses equipamentos, bem como considerando as particularidades de cada parque, ratifica-se o potencial turístico de todos os dois abordados com vistas a tornarem-se efetivos e consolidados atrativos. Deste modo, é preciso averiguar o atual grau de uso pela atividade turística a fim de instaurar medidas plausíveis em resolução ao cenário anteposto. 


\subsection{O Parque da Sementeira}

O Parque Augusto Franco, popularmente conhecido como Parque da Sementeira está localizado no bairro 13 de julho, área nobre da cidade de Aracaju. No momento de sua implantação, o Parque da Sementeira foi contemplado com diversos elementos que podem atrair a variados públicos, como a demanda turística e os residentes, de forma a constituir potencial para diversidade de usos do local. Dentre os atrativos estão quiosques para piqueniques, lagos, eventos culturais, Casa da Ciência e Tecnologia Galileu Galilei (CCTECA, Planetário), uma vasta área verde com uma horta, parque infantil, espaços específicos para práticas de atividades físicas e ainda projetos como o Natal Luz, dentre outros (FIGURA 2).

Figura 2 - Espaços do Parque da Sementeira em Aracaju/SE

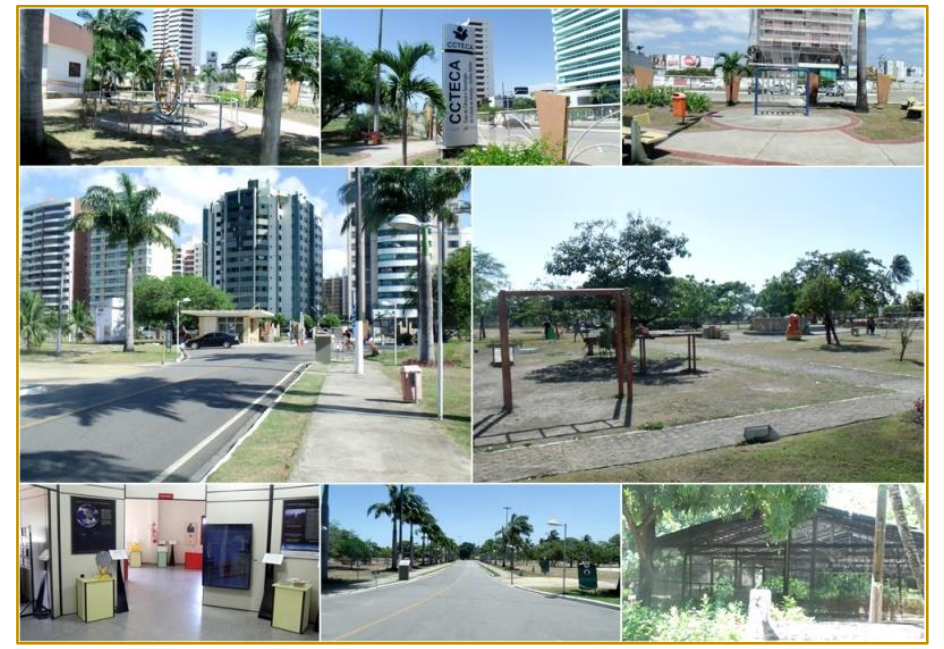

Fonte: Das autoras, 2016.

Em análise dos questionários aplicados aos usuários do Parque da Sementeira, percebese que os frequentadores (64\%) constituemse daqueles que residem nas adjacências. Esses residentes utilizam o parque, em suma, para práticas de sociabilização e de atividade física durante os dias entre segunda e sextafeira. As populações de perfil com menor nível de escolaridade e renda, oriundas de bairros mais distantes e regiões desfavorecidas da cidade, apenas utilizam o parque em finais de semana e feriados. É certo que isso ocorre em virtude dos residentes das adjacências terem mais facilidade de acessibilidade e poder aquisitivo para residir nas proximidades, resultando assim em um maior direito a usufruir de um espaço público da cidade de Aracaju que deveria ser entendido como um direito, igual, de e para todos.

Neste contexto, destacamos os conflitos que surgem entre o consumo dos agentes adjacentes e o uso do espaço do parque público pelos residentes de bairros mais distantes em determinados dias da semana sobretudo de sábado, domingo e feriados uma vez que os moradores do entorno sentem-se "incomodados" com a presença desses indivíduos e grupos sociais (majoritariamente jovens de baixa renda) que utilizam 0 parque para proposição de encontros que visem à interação, paqueras, o consumo de bebidas alcoólicas, fazer novas amizades etc. Percebe-se envolto aos discursos dos moradores dos grandes condomínios ao redor do parque que, não apenas os usos diferenciados e "inapropriados" dados por esses jovens são repudiados, mas também o fato de ser oriundo de localidades periféricas, fator que amedronta aos primeiros dado o enorme imaginário social imbuído de preconceito para com esses grupos que resulta em práticas discriminatórias e de cunho racista.

Diante desse cenário, encontra-se a justificativa para o consumo do parque pelos moradores, sobretudo nos dias entre segunda e sexta-feira, pois os mesmos evitam estar no equipamento nos finais de semana, período em que outros públicos vindos de localidades mais distantes da cidade de Aracaju estão usufruindo do espaço das mais diversas formas. Sob essa perspectiva, a luta de 
classes é vislumbrada ao evidenciar-se que o Parque da Sementeira, por muitas vezes, é entendido como extensão e área de lazer semi-privativa dos condomínios localizados ao redor do mesmo. Esse fator é desencadeado pelas construtoras que, ao ofertar apartamentos nas proximidades do Parque da Sementeira, apropriam-se de um espaço público de lazer para elevar o valor de troca dos imóveis, interiorizando ao comprador que o equipamento é elemento constituinte da propriedade adquirida, fazendo com que este estabeleça domínios territoriais principalmente ideológicos - sobre e no parque. Neste sentido, o parque é convertido em uma mercadoria a ser consumida por aqueles que podem "compra-lo".

Deste modo, há de se considerar que o parque é um território e produto daqueles que residem em suas margens e, portanto, passível de ser permeado por inúmeras relações de poder arbitrárias advindas da ideia de posse e propriedade que levam os donos dos imóveis a designarem, conforme os seus valores e de modo velado, as práticas aceitáveis versus as atividades entendidas como contra-usos baseados, igualmente, na hegemonia da lógica do consumo imposta. De acordo com Leite (2002, p. 121), os contra-usos se caracterizam pelos "[...] usos que podem alterar a paisagem e imprimir outros sentidos às relocalizações da tradição e aos lugares nos espaços da cidade". Com isso, o consumo do Parque da Sementeira por esses grupos são entendidos como contrausos, ou seja, usos inadequados segundo os valores oriundos da hegemonia do consumo que devem ser controlados pela gestão do parque através da figura dos guardas municipais que se encontram no interior do parque ${ }^{24}$.

A partir desse contexto, os fluxos se configuram: os moradores situados ao redor do parque não o frequentam e/ou utilizam aos finais de semana e feriados por se autoconsiderarem uma classe superior frente ao outro tipo de público usuário do parque, e que, por conseguinte não deve usufruir dos mesmos espaços, mas sim, consumir aqueles que gerem distinção. Assim, estes estão mais assiduamente no parque nos dias em que esses indivíduos se fazem ausente do espaço por não poderem usufrui-lo dada sua rotina laboral.

24 Informações extraídas dos questionários aplicados aos moradores da cidade de Aracaju no ano de 2015.
Já no campo do turismo, observa-se que o Parque da Sementeira não é destacado enquanto item e atrativo da oferta turística da cidade de Aracaju, uma vez que não houve percepções de uso e apropriação do parque pela atividade turística durante observação in loco. Porém, é importante destacar que foi comprovado que há, mesmo que mínima, a visitação por parte da demanda turística através do livro de registros de visitação do Planetário localizado no interior do parque; e da ferramenta TripAdvisor com avaliações online dos turistas que visitaram o espaço do parque.

Ao questionarmos os moradores sobre a utilização do parque por turistas, observa-se que há um quantitativo significativo daqueles que afirmam o não uso do parque pelo turista. Esses apontam que os principais fatores que contribuem para não utilização do espaço pelo turista são: a) a falta de divulgação; b) ausência de infraestrutura e, c) inexistência de atrativos capazes de atrair a demanda turística. Contudo, um quantitativo semelhante apresenta uma percepção positiva para a atividade turística no Parque da Sementeira, tanto de existência desta, quanto para potencialidade de visitação por turistas.

Diante da pesquisa realizada com turistas encontrados nos principais atrativos da cidade de Aracaju, - sobretudo na Orla de Atalaia, uma vez que o fluxo de turistas especificamente nesse atrativo é constante observou-se que o Parque da Sementeira é pouco ou não apropriado pela atividade turística, caracterizando assim o seu não uso e não aproveitamento de sua potencialidade em decorrência da falta de divulgação e transmissão de informações da existência do mesmo seja por meio de folders, via Web ou outros meios comunicacionais para aqueles que vêm à cidade e poderiam realizar visitação. Esta afirmação é corroborada por $69 \%$ dos turistas questionados que afirmaram que não visitaram o parque em razão de não saberem da existência desse espaço.

É importante ressaltar também a não importância dada aos elementos do parque como sendo um atrativo turístico da cidade de Aracaju pelo trade turístico da localidade, abarcando as agências de turismo receptivo que promovem os cities tours, e os guias de turismo que não os encaminham os turistas para visitação ao parque (mesmo com $81 \%$ destes demonstrando interesse em conhecer esse espaço) levando-os apenas aos atrativos escolhidos caracterizados como principais e 
representativos da localidade, esquecendo-se da importância que os parques públicos possuem, assim como o seu potencial.

Ademais, não fora possível aplicar questionários aos turistas no campo do objeto de estudo, tendo em vista a dificuldade em encontrá-los nas dependências do parque, podendo-se pressupor que estes não utilizam/utilizaram do Parque da Sementeira em suas visitações à Aracaju. Em decorrência desse fato, bem como considerando que na amostra supracitada nenhum turista apontou ter visitado o parque, não fora possível obter dados referentes às formas de uso dadas por essa demanda. Quando em exercício comparativo às percepções dos moradores, de fato não houve a comprovação de atividade turística realizada no Parque da Sementeira, como afirmado por $50 \%$ dos residentes entrevistados, ratificada juntamente com as razões para não visitação pelos turistas, em que esses apontaram a ausência de divulgação e informação acerca do equipamento como principal razão para não uso do parque.

Contudo, a partir da realização de pesquisa de campo a um dos equipamentos que compõem o parque, o Centro de Ciência e Tecnologia Galileu Galilei (CCTECA, mas popularmente conhecido como Planetário), fora encontrado um livro com registros de visitação que comprovou que há a utilização, ao menos do planetário, por alguns turistas oriundos de Salvador, João Pessoa, Goiânia, São Paulo, Distrito Federal, São Luís, dentre outras localidades. Entretanto, a maior visitação se dá por pessoas da localidade, ou seja, por residentes da cidade de Aracaju. Sendo assim, apesar de não ter havido percepções de uso e apropriação do parque pela atividade turística, foi-se comprovado que há fluxo a partir dos dados levantados no livro de visitação do planetário.

Ressaltamos também que detectamos visitação por parte dos turistas a partir das avaliações dos usuários do Parque da Sementeira na plataforma do TripAdvisor. Percebe-se através das análises das avaliações que existem distintas percepções acerca do Parque. De acordo com uma turista de Ilhéus, o parque da Sementeira é "tranquilo, com área verde para pedalar ou fazer caminhadas. Ambiente agradável. Tem um riozinho com pedalinhos, excelente para levar crianças" (TripAdvisor, março de 2016). Já um turista de Minas Gerais afirma que o parque da Sementeira é "muito legal, fica próximo da Orla de Atalaia, tem lagos, ciclovia, lugares para caminhada, ideal para famílias. Vale conferir" (TripAdvisor, junho de 2015). Outros turistas que avaliaram o parque na ferramenta do TripAdvisor são oriundos do Rio de Janeiro, Pernambuco, Rondônia e Alagoas, e afirmam com frequência a possibilidade da prática de esportes, contato com a natureza, ademais de ressaltarem que o parque é um espaço para estar com a família e propício para a sociabilização.

Em síntese, as atividades que podem ser desenvolvidas pelos turistas durante visita e permanência nos espaços e dependências do Parque da Sementeira se constituem em visitar o Centro da Ciência e Tecnologia Galilei Galileu (CCTECA, Planetário); visitar a horta; participar de eventos diversos que ocorrem no parque; e desenvolver atividades físicas diversas. Juntamente, realizar práticas de sociabilização como encontros com amigos, cônjuges, piqueniques, dentre outros; apreciar e deslumbrar a grande área verde que há no parque, bem como o lago em sua forma original e com decoração natalina ao final do ano com o Projeto Natal Luz. Comprova-se, assim, que o Parque da Sementeira apresenta potencial turístico dado sua infraestrutura para o lazer mediante os atrativos diferenciados, capazes de converter esse espaço em um novo atrativo turístico da cidade de Aracaju que poderá ser inserido nos roteiros turísticos locais com amplas possibilidades de despertar, atrair e recepcionar a demanda turística.

Contudo, diante das análises realizadas buscando-se evidenciar os não usos do Parque da Sementeira, identificou-se que este é pouco apropriado pela atividade turística, conforme destacado anteriormente. Isto porque nenhum dos turistas abordados durante a pesquisa havia visitado o parque em questão, afirmando que as agências de turismo de receptivo e os guias de turismo não se apropriam do espaço para a realização de atividades com os turistas que chegam à cidade de Aracaju, sendo assim utilizado em maioria pela população local que reside, em suma, nas adjacências do equipamento.

Já no que tange ao direito à cidade, apoiado nos dados empíricos coletados por meio de questionários estruturados aos usuários do Parque da Sementeira, observou-se que este ainda permanece sendo uma utopia, uma vez que o público predominante que consome e apropria-se do espaço são aqueles que 
residem nas proximidades do equipamento, fazendo uso constante durante os principais dias da semana para práticas de atividade física e lazer.

\subsection{O PARQUE DA CIDADE}

O Parque Governador José Rollemberg Leite, conhecido popularmente como Parque da Cidade, está localizado em uma área de residência de indivíduos de baixa renda e com grande carência de investimentos públicos. Mediante esses fatores, evidenciase que o Parque da Cidade está situado em uma zona totalmente oposta (zona norte) em relação ao Parque da Sementeira (zona sul), principalmente no que tange às configurações sócio-espaciais e relações de uso e consumo engendradas.
Realizado o levantamento bibliográfico e a pesquisa de campo, constatou-se a partir do inventário proposto que o Parque da Cidade apresenta enquanto equipamentos e atrativos de/para visitação: o Zoológico com animais diversos; o Teleférico que encaminha os visitantes em um passeio para o ponto mais alto do parque; um pequeno haras em que estão alocados alguns cavalos que auxiliam nas práticas de equoterapia; dois bares/restaurantes, estando apenas um em funcionamento; um espaço não pavimentado utilizado para práticas de futebol; e espaços livres diversos apropriados de diversas formas pelos usuários do parque (FIGURA 3). No espaço do parque também é possível realizar trilhas, sendo que uma delas dá acesso a um ponto aonde praticantes de asa delta saltam, com vista para a cidade de Aracaju, o Rio Sergipe e a cidade de Barra dos Coqueiros.

Figura 3 - Espaços e atrativos do Parque da Cidade em Aracaju/SE.

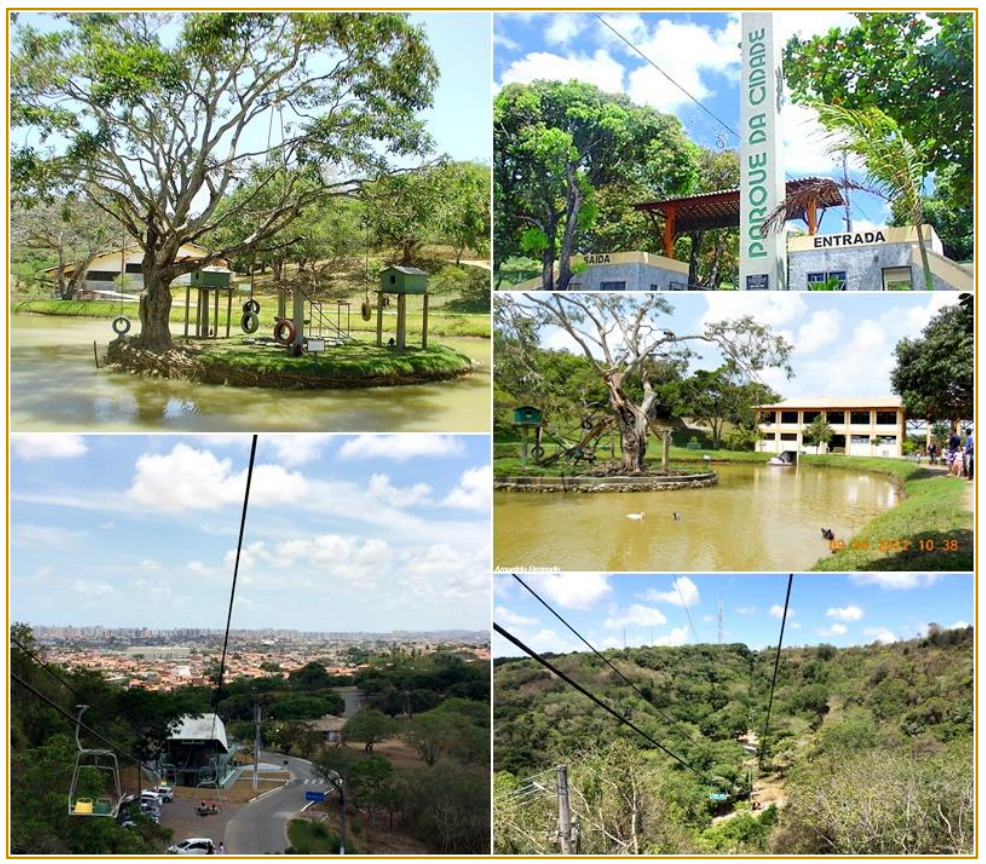

Fonte: Das autoras e Blog Meu Destino, 2016

Em polo completamente antagônico, o Parque da Cidade enfrenta inúmeros problemas estruturais por não fazer parte do rol de investimentos do Estado, privilégio do Parque da Sementeira que está "bem localizado" (em zona de grande interesse para o capital privado). No entanto, embora possua deficiências estruturais, instaura-se o paradoxo por ser o parque que mais recebe demanda turística intermediada por agências de receptivo e guias de turismo; ou desintermediados que souberam do parque através de amigos, parentes e da internet.

O Parque da Cidade, por sua vez, diferentemente do Parque da Sementeira, apresenta-se como a principal área de lazer dada a proximidade das residências - das classes desprovidas de capital, marginalizadas dos processos desenvolvimentistas urbanos. A partir da 
aplicação da técnica de observação in loco foi perceptível que são dados diversos usos ao Parque da Cidade. Os indivíduos acompanhados de amigos, familiares e cônjuges praticam ações de sociabilização, piqueniques, pequenas caminhadas e entram em contato com os animais livres $e$ enclausurados.

Deste modo, diversos usos são dados pelos moradores ao espaço amplo e verde do equipamento, no qual ocorrem principalmente aos finais de semana com a predominância destes usuários e, contrariamente, consumidos por turistas durante os dias úteis. Assim, torna-se interessante perceber como o turista está mais presente no Parque da Cidade e demonstra mais entusiasmo em visitá-lo do que em relação aos demais parques, sendo que por diversas vezes na aplicação de questionários notou-se que a demanda turística não sabia que existiam outros parques públicos na cidade de Aracaju. Por conseguinte, a relação do Parque da Cidade com o turismo se destaca frente ao Parque da Sementeira, uma vez que este último é pouco apropriado pela demanda turística e pelo próprio trade turístico (principalmente as agências de viagens e os guias de turismo).

Por meio da aplicação de questionários estruturados aos usuários do parque que residem na cidade de Aracaju ou adjacências da mesma, verificou-se inicialmente o perfil desses indivíduos. Enquanto resultados, destacamos o nível de escolaridade desses visitantes que se constitui majoritariamente em ensino médio, diferentemente do Parque da Sementeira, onde os moradores adjacentes possuem alto nível de escolaridade. Com relação ao local de procedência, 54\% são oriundos da zona norte da cidade de Aracaju englobando os bairros que estão localizados no entorno do Parque da Cidade. A partir desses dados de perfil levantados algumas hipóteses e questões urgem. Primeiramente, é interessante perceber a escolaridade dos inquiridos atrelada aos bairros de procedência, regiões da cidade de Aracaju com extrema carência de serviços públicos de qualidade, bem como onde estão e residem os indivíduos de baixa renda.

Além disso, a proximidade desses bairros ao Parque da Cidade atrai consideravelmente essa demanda, partindo da hipótese de que a ausência de espaços públicos de lazer para essas comunidades não privilegiadas pelas políticas públicas os leva a um dos poucos equipamentos (senão o único) em que esses indivíduos podem usufruir o tempo do nãotrabalho de forma produtiva, caracterizandose como um mínimo acesso ao que lhes pertence por direito: as práticas e espaços de lazer.

Diante dessa realidade, constata-se que essas comunidades marginalizadas enquanto cidadãs não possuem direito à cidade, justificado pela negligência do poder público em prover locais de entretenimento e vivência da cidade (também) para esses moradores oriundos de regiões não privilegiadas. Por conseguinte, estes ficam privados de participar e compor a dinâmica urbana no que concerne ao lazer, havendo a necessidade de busca de outros espaços não pensados, planejados e direcionados para atender aos usos e ao próprio público dessas regiões visto que seguem a tônica do capital privado, processo que engendra os ditos "contra-usos" a partir da lógica do consumo imposta sob esses espaços-mercadoria - fato esse recorrente no Parque da Sementeira, conforme observamos anteriormente.

Ademais, constatou-se que poucos usuários do Parque da Cidade são oriundos da zona sul da cidade, sendo representados por apenas $8 \%$ da amostra. Entretanto, quando realizamos o cruzamento com os dados de demanda obtidos no Parque da Sementeira é possível captar as contradições existentes na dinâmica urbana de Aracaju. Isto porque se observou que as pessoas oriundas de bairros distantes e segregadas no que tange às políticas públicas de lazer estão frequentemente presentes no Parque da Sementeira usufruindo de seus equipamentos, sobretudo, aos finais de semana e feriados. Todavia, o movimento contrário de indivíduos da zona sul se direcionando ao Parque da Cidade - zona norte - para suas práticas de lazer não ocorre.

Diante disso, corrobora-se com a perspectiva da luta de classes materializada, de forma intangível e velada, na dimensão espacial urbana no qual a classe burguesa detentora de capital não se direciona para os (poucos) espaços de lazer de populações de baixa renda, tendo em vista toda a construção social envolta desses indivíduos, e, sobretudo, da classe. Todavia, essa última classe desfavorecida busca nos espaços da classe dominante usufruir do seu momento de lazer, pois é privado pela máquina estatal de ideologia burguesa de possuir equipamentos 
de qualidade para que possa usufruir nos seus momentos do não-trabalho.

Neste sentido, durante os dias úteis os grupos com poder aquisitivo para residir nas proximidades do Parque da Sementeira o usufruem, e aos finais de semana são menos presentes, uma vez que a classe dominada está a consumir os espaços - de propriedade quase privada das grandes construtoras, transferida para os condôminos no ato da compra dos imóveis -, gerando usos e contrausos que geram estranhamentos e reforço de estereótipos construídos para inferiorizar a classe proletária. Por conseguinte, conflitos e entraves são traçados no espaço urbano, referenciando que a luta de classes permanece na contemporaneidade.

Já no que tange especificamente aos usos designados ao Parque da Cidade, a demanda residente aponta que quando estão usufruindo das áreas do parque desenvolvem atividades de visitação ao zoológico, caminhadas, gincanas, leituras e "evangelizações" ${ }^{25}$, socialização, observam a paisagem e a natureza, realizam piqueniques, descanso, levam as crianças para brincar, etc. Pouco é citado o uso e consumo do passeio do teleférico por essa demanda, uma vez que os mesmos relatam o alto valor na taxa para ter acesso ao equipamento, o que levaria ao uso exclusivo deste pela atividade turística, cabendo a administração do parque adotar medidas de inclusão e democratização do uso, levando-se em consideração que o público é majoritariamente desprovido de recursos financeiros para ter acesso ao teleférico. Ademais, também se notou que os moradores não se apropriam do parque para usos relacionados à atividade física (como corridas a pé e utilizando a bicicleta, por exemplo), o que é comum em parques públicos e recorrente no Parque da Sementeira, conforme constatado.

No tocante à relação entre o Parque da Cidade e a atividade turística, $82 \%$ dos residentes questionados opinam que 0 parque é utilizado por turistas versus 18\% que não acreditam nessa apropriação. Em justificativa para não utilização do espaço do parque por turistas, os 18\% afirmam que não há divulgação, segurança, atrativos, infraestrutura, bem como pela desorganização ligada à má administração dos equipamentos e atrativos, fatores esses que contribuem para o não uso do parque

\footnotetext{
${ }^{25}$ Atividade ligada diretamente a rituais religiosos.
}

pela atividade turística. Por outro lado, os que afirmam que há o uso turístico opinam que, apesar de haver a visitação por parte da demanda turística, esta ainda é pouca (61\%). Estes também afirmaram o alto potencial que a área apresenta para o aproveitamento e desenvolvimento de atividades turísticas (também) pelos eventos que são realizados no interior do parque.

Quando questionados acerca dos usos e atividades que os turistas realizam nas dependências do Parque da Cidade, os residentes que apontaram que há uso do parque pela demanda turística (82\%) afirmam que os turistas visitam o zoológico, o teleférico, apreciam a natureza e a paisagem, tiram fotos, repousam e fazem piqueniques. Desses questionados, $54 \%$ já presenciaram turistas no parque e $46 \%$ nunca os notaram. Os que já visualizaram os turistas no parque indicaram que o turista estava realizando atividades de visitação ao zoológico, passeio no teleférico e tirando fotos (dos animais do zoológico e da natureza).

Já em pesquisa com a demanda turística na Orla de Atalaia, adotando-se o mesmo método utilizado para 0 Parque da Sementeira, os dados mostram que $20 \%$ dos turistas apontaram ter algum conhecimento acerca do Parque da Cidade. Ademais, 16\% dos inquiridos afirmaram já ter visitado o parque frente a $84 \%$ que nunca estiveram no equipamento. Deste modo, nota-se a ausência de divulgação do Parque da Cidade, bem como a não inclusão deste nos passeios das agências de turismo de receptivo. Além disso, embora se tenha apresentado um grande quantitativo de turistas que não visitaram o Parque da Cidade, observa-se que este é mais visitado por turistas frente ao Parque da Sementeira.

Acerca dos $16 \%$ que já haviam visitado o Parque da Cidade, destes, 50\% visitaram o espaço através das informações que obtiveram na internet, sobretudo nas redes sociais. Igualmente, $50 \%$ visitaram o parque através da indicação de amigos e parentes. Novamente, os dados apontam que o Parque da Cidade é apropriado pelos turistas de modo autônomo e independente das agências de turismo de receptivo, tendo em vista que toda a amostra esteve em visitação ao espaço motivado por outros meios. Cabe aqui também apontar o potencial de disseminação de informações através da propaganda boca-a-boca, conforme supracitado; e o poder da internet na 
contemporaneidade enquanto influenciadora dos próximos pontos a serem visitados pela demanda turística informatizada e globalizada.

Quando questionados acerca das atividades realizadas em visitação ao Parque da Cidade, os $16 \%$ apontam ter praticado a visualização e contemplação da paisagem, utilizaram o teleférico, visitaram o zoológico, registros fotográficos, e caminhadas. As atividades apontadas pelos turistas demonstram que 0 potencial do Parque da Cidade não tem sido apropriado por essa demanda. Esse fator pode se dar em decorrência das baixas informações existentes e divulgadas sobre as possibilidades de usos desses espaços públicos de lazer e de grande potencial turístico - afirmação alicerçada nas respostas obtidas pelos próprios residentes.

Por fim, o turista que visitou o Parque da Cidade avalia que o espaço é bom tanto para - lazer, quanto para o turismo por ser diferente, pela natureza, paisagem e teleférico. Os turistas afirmam que o espaço é "importante tendo em vista a preservação da natureza"; "interessante e bonito", entre outros $^{26}$. Assim, analisa-se que o turista (também) apresenta percepção positiva para o potencial turístico do espaço do parque, evidenciando por diversas vezes o aspecto de aproximação com a natureza, corroborando com as afirmações de Gomes (2013) da busca constante do homem urbano contemporâneo pelos espaços ditos e vendidos como naturais pelos discursos hegemônicos, enquanto representações do campo.

Pressupõe-se, perante as informações e dados coletados, que o Parque da Cidade apresenta grande potencial para $\mathrm{O}$ desenvolvimento e aperfeiçoamento das práticas turísticas em suas dependências dado os atrativos que apresenta, sendo reconhecido pelos próprios usuários, muito embora haja inúmeras considerações no que tange à necessidade de melhorias desse espaço. Todavia, a relação do Parque da Cidade com o turismo se destaca frente ao Parque da Sementeira, uma vez que este é pouco apropriado pela demanda turística e pelo próprio trade turístico.

Para além dos dados obtidos com base nos questionários estruturados, concretizaram-se

\footnotetext{
${ }^{26}$ Informações extraídas dos questionários aplicados aos turistas em Fevereiro de 2017.
}

conversas informais com os moradores usuários do Parque da Cidade. Nos discurso foi recorrente a preferência por outros parques de Aracaju - como o Parque da Sementeira -, sem justificativa aparente. Os questionados também lamentam pelas atuais condições do Parque da Cidade, uma vez que, segundo os residentes, o parque deveria ser mais valorizado, levando-se em consideração seu espaço in natura com reserva de mata atlântica.

Diante disso, alguns levantaram questionamentos e apontamentos no que concerne à supervalorização do Parque da Sementeira no imaginário coletivo frente ao Parque da Cidade, tendo em vista que o último apresenta mais atributos e atrativos. Partindo de análises anteriormente realizadas tendo por base o Parque da Sementeira, pressupõe-se que a localização deste pode contribuir e ser um fator de impacto para a preferência deste espaço frente aos outros parques, levando-se em consideração que está alocado em uma área com alto valor de troca estabelecido pelo mercado, agregando imaginários e construções sociais que atraem as populações de diversos pontos da cidade.

No entanto, é interessante perceber como o turista está mais presente no Parque da Cidade e apresenta mais interesse em visitálo do que em relação ao Parque da Sementeira, sendo que por diversas vezes na aplicação de questionários notou-se que a demanda turística não sabia que este equipamento existia na cidade de Aracaju. Assim, observa-se que o morador percebe o Parque da Sementeira como espaço preferencial; já o turista tem o Parque da Cidade como sua principal referência de parque público na cidade de Aracaju; ou seja, turista e morador apresentam percepções distintas acerca dos mesmos espaços urbanos.

Posteriormente à pesquisa de campo realizouse a observação netnográfica na plataforma do Tripadvisor, no qual foram encontradas 473 avaliações de usuários acerca do Parque da Cidade. Dessas, 17 avaliações foram selecionadas para compor a pesquisa de acordo com critérios de distinção nas percepções. Nelas encontram-se críticas, sugestões, em suma, percepções positivas e negativas das experiências dos turistas nesses espaços. São visitantes oriundos, majoritariamente, da região sudeste (São Paulo e Rio de Janeiro), seguido da região nordeste (Bahia e Pernambuco) e da região 
sul e centro-oeste (Mato Grosso do Sul, Paraná e Brasília).

Nas avaliações, os visitantes apontam para o teleférico enquanto um atrativo turístico e elogiam o espaço por ser "arborizado, verde, amplo, limpo". Ainda, relatam que as tarifas do teleférico são baixas; a dificuldade de acesso pelo parque encontrar-se um pouco afastado do centro da cidade, como também pela ausência de sinalização; etc. Entretanto, severas críticas acerca do zoológico são citadas recorrentemente, bem como à aparência de abandono do Parque da Cidade com ressalvas para a segurança e infraestrutura. Neste sentido, observa-se que o turista possui também um olhar crítico tanto quanto os residentes da localidade, e de mesmo modo, informados quanto aos aspectos relacionados à segurança que está suscetível a ação de meliantes.

\section{CONSIDERAÇÕES FINAIS}

O presente estudo teve por objetivo investigar as relações de consumo e usos - incluindo não usos e contra-usos - estabelecidos, especificamente, em dois parques públicos (Parque da Sementeira e Parque da Cidade) da cidade de Aracaju, Sergipe, selecionados considerando a posição antagônica que ocupam em termos tanto de localização, quanto no que concerne aos processos de produção e consumo. Em análise comparativa, comprovou-se que as dinâmicas em relação à apropriação desses espaços públicos são distintas, até mesmo em equipamentos que apresentem fins similares e que estejam alocados na mesma cidade, como é o caso do Parque da Cidade e o Parque da Sementeira. Além disso, o fator localização influencia por completo as formas de consumo desses espaços públicos de lazer e turismo na contemporaneidade.

A tônica dos espaços-mercadoria geram diversos desdobramentos sobre as relações sócio-espaciais, nos quais o elitismo exacerbado predominante configura vínculos de contra-usos, levando-se em consideração que a camada de alto poder aquisitivo repudia a presença das classes de baixa renda justificado pelos "usos inadequados" dados por esses indivíduos aos espaços do parque público, no qual deve ser mantida a distância e distinção, tendo como resultado final a mudança nas relações entre os cidadãos e a cidade. Com isso, ao enfatizarmos as utopias que estão associadas ao direito à cidade, apontamos para uma crítica radical ao planejamento tecnocrático realizado pelo Estado e suas formas de reducionismo dos espaços públicos a meros objetos do mercado, como no caso do Parque da Sementeira, em que o equipamento é entendido como mercadoria, servindo, maiormente, à especulação imobiliária e, consequentemente à lógica do capital.

Já no caso do Parque da Cidade, apesar de se configurar como um atrativo e de receber visitação pela demanda turística percebe-se que há necessidade de se estabelecer estratégias e ações que visem à melhoria do espaço não somente para os turistas, mas, sobretudo, para os residentes, visto que o parque público ainda é majoritariamente apropriado para o lazer dos moradores da cidade de Aracaju. No entanto, medidas cabíveis podem ser tomadas no que concerne à divulgação e exposição do potencial que o parque apresenta viabilizando a visitação por parte dos turistas.

Neste sentido, é crucial o despertar dos agentes públicos e privados para perceber que os parques públicos podem se constituir em atrativos turísticos importantes de um destino ao levar em consideração que estes exprimem em sua paisagem a história, herança, construções sociais e características intrínsecas da localidade, ou seja, os parques possuem unicidade em suas configurações. $O$ planejamento no que tange aos roteiros turísticos deve partir do objetivo de estreitar e aproximar a atividade turística dos parques públicos da cidade a partir das parcerias e diálogos e de perspectivas inovadoras, não sendo apenas configurados com base em comissionamentos ou em grandes atrativos monopolizados que não permitem a diversificação da oferta turística. 


\section{REFERÊNCIAS}

[1] BARRETO, D. C. M., et.al. Parque Augusto Franco - Aracaju/SE: As diferentes formas de apropriação dos espaços públicos. In: Anais do $1^{\circ}$ Seminário de Turismo e Geografia. São Cristóvão: Universidade Federal de Sergipe, 2010. p. 22-34. (CD-ROM).

[2] CAPEL, $H$. Jardines y Parques en la ciudad. Revista Ciencias, n. 68, 2002, p. 4-16. < http://www.revistaciencias.unam.mx/pt/85-

revistas/revista-ciencias-68/728-jardines-y-parquesen-la-ciudad-ciencia-y-estetica.html>

[3] CARLOS, A. F. A. O Consumo do Espaço. In: CARLOS, A. F. A. et. al. Novos Caminhos da Geografia. São Paulo: Contexto, 1999.

[4] GOMES, M. A. S. Os parques urbanos e a produção do espaço urbano. Jundiaí, SP: Paco Editorial, 2013.

[5] HARVEY, D. O direito à cidade. Revista Lutas Sociais, Rio de Janeiro. n. 29, p.73-89, 2012.

[6] LAPA, D. L. Percepções do uso turístico do espaço urbano: Estudo sobre o Parque da Sementeira. In: Anais do $1^{\circ}$ Seminário de Turismo e Geografia. São Cristóvão: Universidade Federal de Sergipe, 2010. p. 35-47. (CD-ROM)
[7] LEFEBVRE, H. O Direito à Cidade. 5. ed. São Paulo: Centauro, 2008a.

[8] A Revolução Urbana. 3. ed. Belo Horizonte: Editora UFMG, 2008b.

[9] LEITE, R. P. Contra-usos da Cidades: lugares e espaço público na experiência urbana contemporânea. 2. ed. Campinas, SP: Editora da UNICAMP; Aracaju, SE: Editora UFS, 2007.

[10] LOBODA, C. R. Espaço Público e Práticas Socioespaciais: uma articulação necessária para análise dos diferentes usos da cidade. Caderno Prudentino de Geografia, Presidente Prudente, Vol. 1, p.32-54, 2009.

[11] MELO, M. I. O.; DIAS, K. S. Parques Urbanos: Práticas de Lazer e Turismo. In: IX Seminário da Associação Nacional Pesquisa e PósGraduação em Turismo. São Paulo: Universidade Anhembi Morumbi, 2012. p.1-15. Disponível em: < http://www.intranet.cet.unb.br/portal/images/stories/ divulgacao/mariana\%20melo.pdf>

[12] RODRIGUES, L. P.; SANTOS, C. A. J. Os Parques Urbanos de Aracaju/Se - Brasil enquanto Espaços Públicos de Lazer e Turismo. Revista Caribeña de Ciencias Sociales, p. 1-15, 2018.

[13] SANTOS, M. Espaço do cidadão. 3.ed. São Paulo: Nobel, 1997. 


\section{Capítulo 5}

\section{MACAE COMO CIDADE MÉDIA PELA ATRAÇÃO DE MOBILIDADES PENDULARES}

\section{Célio Fidelis Quintanilha}

Felipe Ricardo Branco do Nascimento

\section{Lucas Gomes Maia}

Resumo:O presente trabalho tem como objetivo analisar a polarização exercida pelo município de Macaé em relação a outros municípios a fim de enquadrá-la ao conceito de cidade média, a partir de dados referentes às migrações de trabalhadores oriundos de diferentes cidades - principalmente no que tange as mobilidades pendulares de frequências distintas. Para tanto, a pesquisa engloba o período desde a definição de Macaé como sede das atividades petrolíferas da Região Norte Fluminense (na década de 70) até o ano de 2016, quando as dinâmicas do setor petrolífero na região apresentaram sinais de desaquecimento em consequência da conjuntura econômica mundial e nacional.

Palavras-chave: Macaé, cidade média, migração. 


\section{1- INTRODUÇÃO}

A Constituição de 1988 possibilitou a transferência de maiores responsabilidades e autonomia aos municípios brasileiros. Em alguns casos, as metrópoles perderam centralidade, enquanto outros municípios conseguiram atingir uma posição de referência em seus respectivos estados. Esse fato pode ter contribuído para promover o fenômeno da descentralização, sobretudo a industrial.

Além da descentralização, os últimos 40 anos apresentaram um ritmo de crescimento das metrópoles inferior ao que se via desde o processo de industrialização nos anos 30 . Por outro lado, o ritmo de crescimento de cidades de médio porte tem aumentado. No estado do Rio de Janeiro, por exemplo, após um período de estagnação entre as décadas de 80 e 90, observa-se que o dinamismo econômico é retomado através do desempenho de algumas cidades do interior.

Apesar da descentralização ter ocorrido também em escala regional, retirando do sudeste parte da sua participação no PIB do país, a retomada econômica do Rio de
Janeiro permitiu que o estado fluminense aumentasse a sua atuação, por meio do dinamismo econômico de alguns municípios que passaram a assumir uma centralidade local, polarizando municípios menores no seu entorno. Nesse sentido, "a base territorial das atividades que sustentam a reestruturação da industrialização e a consequente retomada do crescimento econômico do estado é o interior" (OLIVEIRA: 2008, 158), onde é encontrada a maioria dessas novas centralidades municipais.

Como descrito por Santos (2006), entre os anos de 1985 e 2005 a capital do Rio de Janeiro perdeu mais de 67 mil postos de trabalho formal, enquanto o estado ganhou mais 517 mil novos empregos; por outro lado, no que tange as novas contratações, as cidades que assumiram centralidade econômica no interior ficaram acima da média nacional. De acordo com Santos, até a década de 90, Macaé (núcleo da economia do petróleo) teve um crescimento de 380\% em relação a novas vagas formais, enquanto a média fluminense foi de $119 \%$ e a nacional de $171 \%$.

Mapa 1: Mapa político do estado do Rio de Janeiro

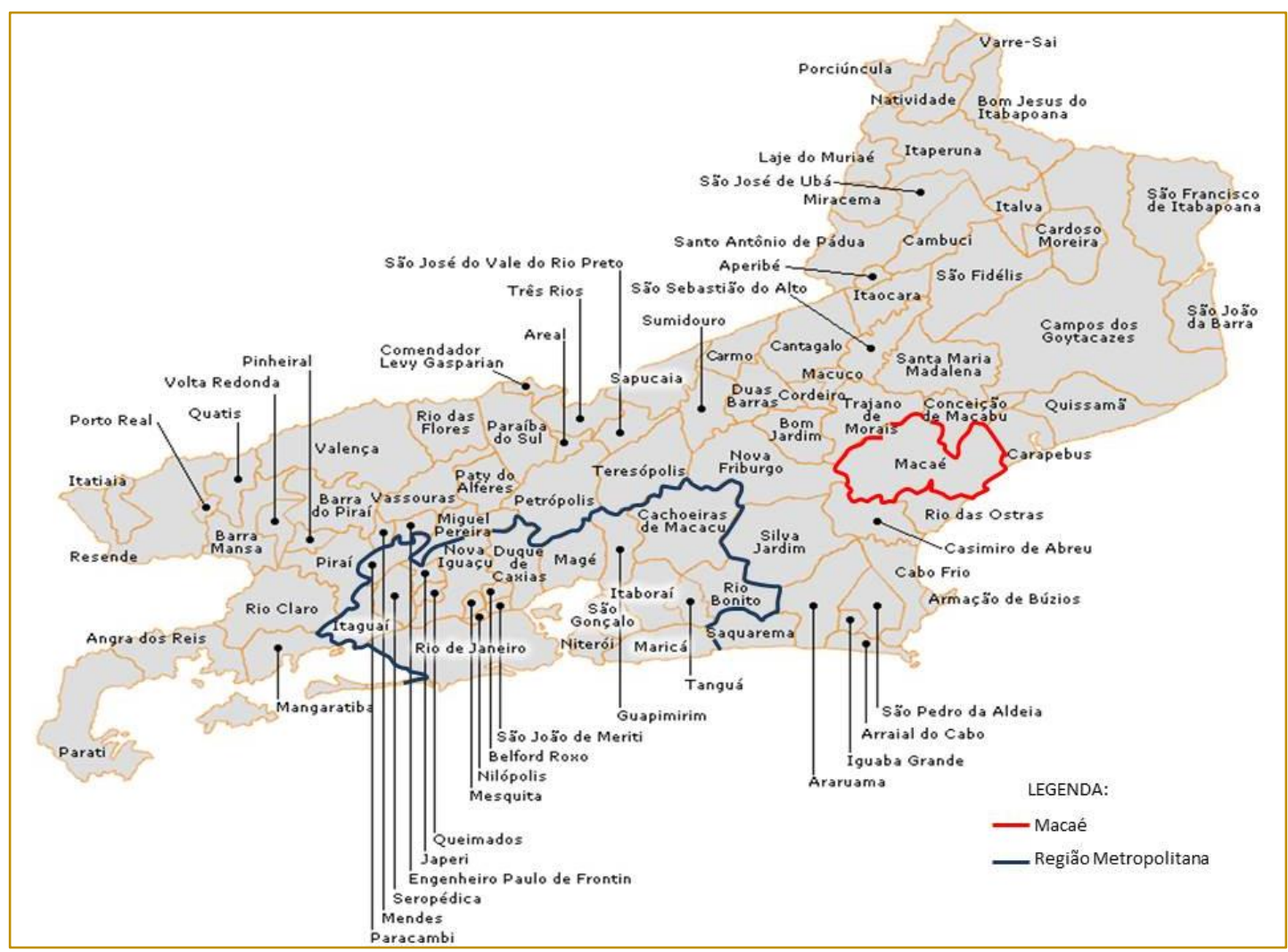


Até a década de 70, "a economia de Macaé fundamentava-se no plantio de cana-deaçúcar e de café, na pecuária e na extração de pescado (MOTA, et al: 2007, 290). Segundo dados do Instituto Brasileiro de Geografia e Estatística (IBGE), com 65.318 habitantes, o município de Macaé era, até então, de pequeno porte. Em consequência da descoberta de petróleo na Região Norte do estado do Rio de Janeiro, em 1974 o município foi definido como sede das atividades extrativistas e iniciou um novo ciclo econômico, atraindo empresas e pessoas. Essa mudança provocou o rápido crescimento demográfico e o levou a atingir o número de 206.728 habitantes, de acordo com o Censo de 2010 (IBGE).

Além de Macaé, houve o crescimento populacional de outros municípios das Regiões Norte Fluminense e das Baixadas Litorâneas. Para Oliveira (2008), a demanda por novas residências dos trabalhadores ligados às atividades extrativistas gerou tal crescimento, sobretudo na cidade de Rio das Ostras. Essa demanda surgiu com a crescente valorização da propriedade privada em Macaé e pelo fato da atividade petrolífera, em relação aos salários dos trabalhadores, não promover o desenvolvimento igualitário de toda a cadeia produtiva. Nesse sentido, ressalta-se que

\section{[...] as atividades industriais ligadas ao setor extrativista, diante das novas tecnologias e dos equipamentos que utilizam, não são fechadas em si mesmas, explorando os recursos existentes no território até o seu esgotamento, com uma força de trabalho localizada no seu entorno. São atividades que estruturam uma economia que se regionaliza, uma vez que há uma conjugação de forças e interesses que põem em relações constantes e trocas regulares os recursos técnicos e humanos existentes em vários lugares ao mesmo tempo, aproximando pessoas e lugares, sobretudo nas cidades dessa região (OLIVEIRA, 2008, 182).}

A centralidade perante os municípios das regiões Norte Fluminense e Baixadas Litorâneas dá à cidade de Macaé o exercício de polarização do entorno, pois nela os serviços são aglomerados e dependências e interações são estabelecidas com os demais municípios. Até mesmo Campos dos
Goytacazes, que historicamente apresentavase como centro econômico da região, perdeu importância com a decadência da produção sucroalcooleira e com a afirmação de Macaé como polo petrolífero.

Uma vez que Campos dos Goytacazes é maior que Macaé nos aspectos territorial e populacional, evidencia-se, portanto, que assumir uma posição estratégica na articulação com as condições de produção não tem a ver com o tamanho da cidade. Diante dessa perspectiva, entende-se que a posição estratégica de Macaé faz parte de uma rede que enfatiza a sua dependência em relação aos demais municípios, pois é fato que ela não transformou-se sozinha. Logo, compreende-se que toda centralidade é relativa e que, para haver o centro, deve haver a periferia. Sendo assim, a dinâmica exercida entre Macaé e o seu entorno sugere enquadrá-la ao conceito de cidade média ainda que esta concepção seja, na atualidade, objeto de diversos estudos acadêmicos que buscam o aperfeiçoamento dessa definição.

Com a finalidade de discorrer sobre "hierarquia urbana" e toda e qualquer construção social, é preciso destacar e articular conceitos fundamentais do saber geográfico que dão suporte ao presente trabalho. Entender a lógica de determinado espaço geográfico, que polariza uma ou mais regiões do seu entorno (e até mesmo municípios mais distantes), é entender a prática social de produção e reprodução do espaço em determinado contexto histórico. Para tanto, torna-se necessária apresentação de um breve ensaio sobre o conceito de região.

\section{2- REGIÃO, QUAL A SUA RELEVÂNCIA CONTEMPORÂNEA?}

O conceito de região, um dos mais tradicionais da Geografia, foi alvo de inúmeras críticas no final do século XX por não abranger o papel do Estado e a existência das classes sociais em sua definição. Em correspondência com essa acepção, Yves Lacoste (1988), cuja crítica era feita a uma determinada leitura (clássica) da região de Paul Vidal de la Blache, utilizou o termo "conceito-obstáculo".

A região lablacheana, além de ter a sua unidade enraizada na própria percepção popular, fornece indícios de uma harmoniosa 
relação entre o homem e seu meio natural, no qual as "divisões naturais" seriam dotadas de densidade histórica e cultural.

Em sua obra "Las divisiones fundamentales del territorio francès", la Blache sugere que os nomes das "divisões naturais" fossem empregados e reconhecíveis por qualquer camponês. Nesse sentido e à luz dessa interpretação, região seria uma entidade espacial concreta, existente independentemente da consciência humana.

Embora o termo pertença ao campo de estudo da Geografia, a definição de região não ficou restrita aos geógrafos. Com a sua teoria dos "polos de crescimento e desenvolvimento", o economista François Perroux exerceu grande influência sobre os economistas regionais e também sobre os geógrafos (em especial os brasileiros).

Das reflexões de Perroux derivam as ideias
referentes a três tipos de "região": a
"região homogênea" (uma área com
características que a diferenciam das
áreas circunvizinhas ou circundantes), a
"região funcional" (significando,
principalmente, uma área polarizada por
um determinado centro nos marcos de
uma rede urbana) e a "região-programa"
(a área de aplicação de um determinado
plano de "desenvolvimento regional")
(SOUZA, 2013, p.139).

Ainda hoje, o debate sobre o conceito de região é necessário, pois dentro de uma região, os capitais são geografizados em conformidade com a lógica do contexto histórico e geográfico de sua criação. Com os avançar do tempo, o que se convencionou chamar de região aparece como equivalente à ideia de "melhor lugar"; ou seja, região é uma espécie de objeto de desejo, de intencionalidade geopolítica e de realizações de determinado número de intervenções no espaço.

O geógrafo brasileiro Milton Santos (1985) corrobora essa teoria ao afirmar que uma região é o locus de determinadas funções da sociedade total em um dado momento. Isso poderia ser evidenciado pelo fato de que, no passado, o mesmo fenômeno se produziu e as divisões espaciais do trabalho criaram instrumentos de trabalho fixos, ligados às diversas órbitas do processo produtivo.
Retomar o estudo das regiões produtivas (SANTOS, 1985) é fundamental para o melhor conhecimento das particularidades de um fenômeno estudado; tendo em vista que, por meio da inserção no todo, busca-se o entendimento do todo graças à compreensão de uma de suas partes. Para isso, torna-se necessária a análise de sua estrutura interna ao longo das articulações do fenômeno estudado com outros fenômenos, e com a totalidade correspondente. Tais especificidades se relacionam diretamente com o território. Esse, por sua vez, é formado por frações funcionais que se articulam no decurso de fluxos que são criados em função das atividades desempenhadas, da sociedade e da herança espacial. Nesse sentido, e em atenção às proposições anteriormente apresentadas, acredita-se ser imprudente e impreciso tecer uma análise espacial sem levar em consideração o fator "tempo", isto é, a geo-história dos fenômenos.

\section{3- CIDADE MÉDIA, O QUE É?}

Há, no meio acadêmico, uma "dificuldade em definir cidade média, quer seja pela heterogeneidade das realidades, quer seja pela temporalidade dos fenômenos econômico-sociais, cujas constantes mudanças condicionam $\mathrm{O}$ enquadramento dos territórios não metropolitanos" (COSTA: 2002, 102). Existem, portanto, especificidades que contribuem para essa dificuldade do conceito em dar conta do que seja, efetivamente, uma cidade média. Os obstáculos para o entendimento desse conceito correspondem aos critérios utilizados pelos autores das pesquisas e também pelas particularidades de cada cidade.

A terminologia "cidade média" é a mais utilizada no Brasil, porém cabe ressaltar que autores de outras nacionalidades utilizam termos diferentes para o emprego desse conceito e, em alguns países, elas aparecem como "cidades intermediárias". De qualquer forma, o pensar sobre a cidade média pode ser análogo a uma reflexão que considere sua dimensão quantitativa na escala urbana, ou a uma reflexão que a relacione com as políticas de ordenamento e desenvolvimento, interligando-a com a escala regional.

$\mathrm{Na}$ década de 70 , cidade média era uma terminologia mais conhecida por utilizar o caráter quantitativo e figurava no que estivesse entre a grande e a pequena cidade. 
Para isso, do ponto de vista de Silva (2013), eram levados em consideração o porte demográfico e a extensão física da cidade como variáveis mais importantes na sua delimitação. Porém, essas variáveis, atualmente, são consideradas rígidas e estáticas.

Alguns estudos que partem de dados populacionais sugerem que as cidades médias são aquelas que possuem um número específico de habitantes e com intervalo limitado, geralmente, por instituições de estatísticas que priorizam uma hierarquia quantitativa entre as cidades. Segundo o IBGE, cidades médias são as que possuem entre 100 mil e 500 mil habitantes e, de acordo com a Organização das Nações Unidas (ONU), são as que possuem entre 100 mil e um milhão de habitantes. Outros estudos já sugerem o limite de 350 mil habitantes por considerarem todo centro urbano que contenha um número maior como possuidor de características de grandes concentrações urbanas.

Santos (1993) recomenda cautela com o uso de quadros estatísticos para classificar uma cidade média, pois um mesmo número quando analisado em épocas diferentes pode adquirir significados distintos. É relevante notar também que duas cidades com número igual de habitantes não serão equivalentes se estiverem em regiões cujos processos de urbanização possuem diferenças consideráveis. A questão demográfica, portanto, é importante, mas possui limitações e não deve ser o elemento fundamental da análise, pois há cidades pequenas cumprindo funções centrais na região onde se encontram. Desse modo, não há uma relação entre o tamanho populacional de uma cidade e o papel dela na rede urbana.

Não obstante, a demografia não deve ser desprezada nos estudos; deve ser inserida às demais variáveis que possibilitam a compreensão das cidades médias, já que, sozinha, a demografia atribui um caráter que refere-se mais ao porte da cidade do que propriamente às suas relações e funções. E existem diferenças entre uma cidade de porte médio e uma cidade média.

Diversos podem ser os critérios para a definição de uma cidade média e, por isso, talvez haja maior dificuldade em identificá-las como tais. Algumas metodologias diferentes são usadas para que a união de fatores possa produzir um resultado mais próximo desse conceito. Além das metodologias quantitativas, também são utilizadas as de caráter qualitativo, em que questões como a oferta de empregos, bens e serviços, a distância das áreas metropolitanas, a circulação de linhas de transportes regulares e a relevância regional são importantes fatores de contribuição à análise.

Assim como a de Castello Branco (2006), pesquisas enfatizam a centralidade como definidora das cidades médias. Para a autora, a relevância do estudo deve estar situada nos tamanhos populacional e econômico, no grau de urbanização e na qualidade de vida.

Em outra perspectiva, as cidades médias são "aquelas que, além de terem tamanho demográfico correspondente a este porte, desempenham claros papéis intermediários entre a(s) metrópole(s) e as cidades pequenas que compõem uma rede urbana" (SPOSITO: 2004, 126). A rede urbana e a interação entre cidades apresentam funções diferenciadas para elas, e essas funções podem auxiliar na percepção da cidade média que polariza as demais. Com isso, da combinação desses fatores diferenciados surge a necessidade de examinar as diferentes escalas para fins de análise das cidades médias. De acordo com Corrêa (2006), cada cidade da rede tem um modo e uma intensidade de participação no processo; do contrário, teria sua existência inviabilizada.

Sposito (2001) enfatiza a relevância do papel que a cidade desempenha regionalmente e afirma a importância da posição na divisão do trabalho e da posição geográfica nas relações espaciais entre as cidades, principalmente nos âmbitos econômico e de consumo. Para a autora, cidades médias são centros regionais importantes que funcionam como ligação entre pequenas e grandes cidades. Porém, para Leitzke e Fresca (2009, apud SILVA, 2013) a ideia de elo entre cidades menores maiores não é suficiente para definir uma cidade média, pois

\footnotetext{
[...] atualmente a globalização permite-nos ir além da simples relação entre duas cidades separadas apenas por um nível hierárquico. Ou seja, a população de uma cidade pequena não precisa recorrer mais à cidade média como elo à grande. A evolução dos meios de transporte e das comunicações permite que se vá
} 
diretamente à grande cidade, ou mesmo à metrópole. (LEITZKE; FRESCA, 2009, p.7).

Sendo ou não um elo, a cidade média está inserida em uma divisão territorial do trabalho. Santos e Silveira (2001) argumentam que esta divisão "[...] cria uma hierarquia entre lugares e redefine, a cada momento, a capacidade de agir das pessoas, das firmas e das instituições". Para os autores, as funções do novo espaço geográfico são configuradas pela distribuição das indústrias, dos serviços e da agricultura; pelas normas financeira, fiscal e civil; e pelos movimentos da população.

As diversas formas de enquadrar uma cidade no conceito de cidade média exigem que o presente trabalho defina uma como sendo a sua diretriz. Por essa razão, é importante afirmar que, apesar de empregar dados referentes às migrações de diferentes pendularidades que a cidade de Macaé atrai, não serão utilizados para tal enquadramento somente os seus números demográficos, bem como seu tamanho populacional. Serão consideradas as relações da cidade com o seu entorno mais imediato e também com municípios vizinhos - o que caracteriza sua relevância regional na divisão do trabalho. Em contrapartida, não será destacada a sua posição como elo entre a metrópole e as municipalidades menores e dependentes da sua rede de serviços, pois os municípios da Região Norte do estado não necessariamente são dependentes de Macaé para acessarem a metrópole fluminense.

\section{4- MACAÉ COMO CIDADE MÉDIA A PARTIR DAS MIGRAÇÕES}

A cidade média desempenha um papel específico na rede urbana em que está inserida e este papel se apresenta nas influências que exerce sobre as demais cidades. Forma-se, portanto, uma rede de interações condicionada pelas dependências e pelas trocas. Analisando os papeis das cidades, concorda-se que,

Primeiramente, a cidade transforma o espaço onde está implantada, quer diretamente, quer pela influência periférica, positiva ou negativa, que exerce. Em segundo lugar, as cidades não vivem isoladas; mantém entre elas relações de troca ou, em certos domínios, vivem em concorrência; portanto, as cidades participam numa estrutura horizontal. Em terceiro lugar, há cidades modestas - pela sua dimensão, nível ou natureza dos seus equipamentos - que podem depender de cidades mais favorecidas: pertencem, então, a uma estrutura vertical; esta conduz à noção de classificação e de rede. (BEAUJEUGARNIER, 1997, p.47-48).

Podem ser diversas as formas de apresentar a centralidade de uma cidade média em comparação às outras cidades da mesma rede. Porém, neste trabalho, Macaé é mostrada como cidade média a partir da análise dos movimentos pendulares feitos pelos trabalhadores que entram e saem da cidade diariamente e semanalmente.

A desconcentração industrial (fenômeno que está acontecendo durante as últimas décadas em diversas partes do mundo) é um dos fatores fundamentais para compreendermos a dinâmica demográfica das cidades médias. Mediante a definição de Macaé como centro da produção petrolífera, diversos outros fenômenos espaciais puderam ser observados: entre eles, a geração de novos postos de trabalho formais e informais. Por representar um mercado de trabalho flexibilizado que se mostra cada vez mais presente no cotidiano, julga-se significativo destacar a importância da informalidade. No entanto, devido à dificuldade de encontrar dados que a representem, o presente trabalho não considera esse aspecto.

Em razão da instalação da Petrobrás na cidade e, consequentemente, das empresas prestadoras de serviços, proporcionou-se uma considerável atração de mão de obra em Macaé. Para Mota et al. (2007), o território sob a influência da indústria petrolífera sofre a imposição de uma reorganização espacial das atividades, por conta do específico dinamismo desse tipo de indústria, que atrai, além de grande contingente populacional, uma série de atividades complementares. Contudo, a atividade extrativista de petróleo requer qualificação dos trabalhadores. Sendo uma cidade cuja economia era baseada em agricultura, pecuária e pesca, Macaé não conseguiu atender àquela demanda de imediato e, por essa razão, a mão de obra técnica surge do seu exterior. 
Nos anos 90, superando o município de Campos dos Goytacazes, Macaé despontava como principal destino do norte do estado, no que se refere à dinâmica da metrópole fluminense. Nos primeiros anos deste século, a ocupação dos trabalhadores em Macaé, especialmente os qualificados, mostrava uma considerável diferença sobre vagas de restrita especificidade técnica quando comparada com a dos trabalhadores não migrantes e não qualificados. De acordo com Paganoto (2008), 78\% dos trabalhadores que recebiam mais de 10 salários mínimos eram migrantes, enquanto o índice de desemprego era maior entre os trabalhadores nascidos na cidade.

Na leitura de Mota et al. (2007), corrobora-se que os altos investimentos tecnológicos e de modernização que a indústria do petróleo carrega puderam ser percebidos na região como um todo, mas com maior força em Macaé onde foram gerados novos padrões demográficos e de migrações. Em um espaço temporal relativamente curto, esse conjunto de fatores foi responsável por um processo de urbanização intensificado, na medida em que

\begin{abstract}
[...] as cidades médias apresentam-se como espaços privilegiados de alocação destes investimentos, dos quais decorre o fortalecimento do papel destas cidades no que tange ao oferecimento de funções, bens e serviços aos moradores da sua hinterlândia e de áreas rurais ou urbanas mais ou menos distantes. Assim, este processo implica no reforço ao papel das cidades médias como espaços de consumo locais e regionais, reforçando a centralidade e intermediação destas cidades.(OLIVEIRA JÚNIOR, 2008, p.217)
\end{abstract}

Com a rápida urbanização da cidade e a chegada de novas empresas e pessoas de vários lugares fluminenses, nacionais e internacionais, a valorização imobiliária aconteceu no mesmo ritmo. Juntamente com a mão de obra técnica e especializada que justifica maiores salários, novos bairros foram criados para este público recente. Mas não foram somente os trabalhadores técnicos que chegaram a Macaé, pois grande quantidade de pessoas, que contavam com a própria sorte, migrou também de diversos lugares em busca de oportunidade de trabalho.
Do ponto de vista das migrações, vários movimentos são percebidos ao analisar a cidade de Macaé. O primeiro deles é o que se refere à migração do campo para a cidade. Em 1970, de acordo com o IBGE, aproximadamente $40 \%$ da população macaense morava nas áreas rurais. Em paralelo a esses dados, o Censo de 2010 (IBGE) mostra que apenas $1,87 \%$ da população mora no campo.

A valorização imobiliária da cidade de Macaé manteve seu ritmo de aceleração e promoveu algumas movimentações dentro e fora do município. No âmbito intramunicipal, observase a setorização das classes sociais que acompanha a setorização dos bairros - fato que evidencia a prioridade dada aos trabalhadores das empresas multinacionais instaladas para a prestação de serviços à Petrobrás. Já em eixos de expansão que seguem uma linha diferente da expansão dos bairros nobres, surgem bairros pobres e favelas. Compreende-se, portanto, que o crescimento da urbanização macaense ocorreu de forma desordenada e, no que tange os valores dos imóveis, promoveu a segregação sócio espacial. Como descrito por Mota et al. (2007), a população local, os empresários e funcionários das indústrias elegeram a especulação imobiliária como um dos principais problemas da cidade.

O segundo movimento de migrações percebido para Macaé ocorre na escala intermunicipal, cuja movimentação acontece pela pendularidade diária que trabalhadores fazem de casa para o trabalho. Normalmente, eles escolhem morar em um município vizinho devido à oferta de moradia mais barata. Nesse sentido,

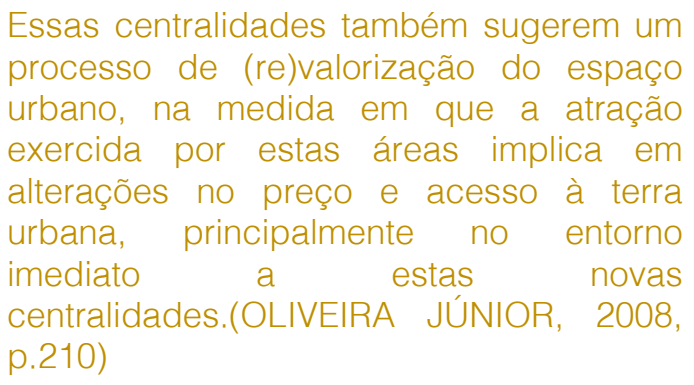

A crescente economia do petróleo e as mudanças nas legislações que distribuem royalties para as administrações federal, estaduais e municipais fizeram surgir na década de 90 algumas emancipações e a 
formação de novas sedes de municípios. Duas delas no limite imediato com a cidade de Macaé: Rio das Ostras, em 1992; e Carapebus, em 1997. Além dessas, e sem fazer limite com Macaé, foi fundado o município de Quissamã, em 1989. Tais localidades são impactadas diretamente pela proximidade com a sede das atividades extrativistas de petróleo da região e, dentre os impactos, encontram-se os movimentos pendulares feitos diariamente pelos trabalhadores.
É sabido que outros municípios, tanto da Região Norte Fluminense, quanto das Baixadas Litorâneas, também são impactados pela pendularidade de trabalhadores em direção a Macaé. Sendo assim, na tentativa de deixar a análise mais próxima da realidade, consideraram-se como referência os dados do IBGE para os municípios de limites mais imediatos, tais como Rio das Ostras, Carapebus, Conceição de Macabu, Casimiro de Abreu e Quissamã, uma vez que a gravitação desses municípios na cidade de Macaé é mais perceptível.

Tabela 1: Dados de população, migração e deslocamentos.

\begin{tabular}{|c|c|c|c|c|c|}
\hline Município & $\begin{array}{c}\text { População } \\
\text { Total }\end{array}$ & $\begin{array}{c}\text { População } \\
\text { Urbana }\end{array}$ & $\begin{array}{l}\text { Não residiam no } \\
\text { município até } \\
2005\end{array}$ & $\begin{array}{c}\text { Trabalham no } \\
\text { próprio } \\
\text { município }\end{array}$ & $\begin{array}{l}\text { Trabalham } \\
\text { em outro } \\
\text { município }\end{array}$ \\
\hline Macaé & 206.728 & 202.859 & 29.910 & 100.153 & 2.154 \\
\hline $\begin{array}{l}\text { Rio das } \\
\text { Ostras }\end{array}$ & 105.676 & 99.905 & 35.611 & 35.519 & 14.492 \\
\hline Carapebus & 13.359 & 10.542 & 1.958 & 3.604 & 2.449 \\
\hline $\begin{array}{l}\text { Conceição } \\
\text { de Macabu }\end{array}$ & 21.211 & 18.337 & 1.310 & 6.282 & 3.341 \\
\hline $\begin{array}{l}\text { Casimiro } \\
\text { de Abreu }\end{array}$ & 35.347 & 28.521 & 6.934 & 12.265 & 4.774 \\
\hline Quissamã & 20.242 & 12.996 & 1.919 & 7.198 & 1.303 \\
\hline
\end{tabular}

Os números da tabela 1 mostram primeiramente o caráter urbanizado das referidas cidades e, em seguida, o movimento populacional em direção a esses municípios após o ano de 2005. Neste caso, Rio das Ostras conseguiu atrair o maior número de novos moradores, ficando à frente da própria Macaé - o que nos permite sugerir que, nos últimos anos, a preferência por residir fora da cidade de Macaé tenha aumentado. Em relação ao exame desses dados, Paganoto (2008) alega que o custo elevado da moradia provoca maior procura em municípios vizinhos, em especial Rio das Ostras. Estes municípios terminam por desempenhar o papel de "diques populacionais" (PAGANOTO: 2008, 14), absorvendo migrantes que antes se dirigiam diretamente para Macaé.

Por essas razões, torna-se evidente a atração que Macaé exerce sobre o movimento dos trabalhadores dos municípios vizinhos, ao mesmo tempo em que se vê a permanência de trabalhadores macaenses na própria cidade, pois, comparativamente, é baixa a quantidade de pessoas que saem de Macaé para trabalhar. Apenas 2,1\% dos trabalhadores residentes em Macaé exercem suas funções fora do município. Nos demais municípios, essa proporção tem outros resultados: em Rio das Ostras são $28,9 \%$ os que saem do município todos os dias; em Carapebus são 40,4\%; em Conceição de Macabu são 34,7\%; em Casimiro de Abreu são $28 \%$ e em Quissamã são 15,3\% (de acordo com os dados do IBGE, entre os setores que mais atraem a movimentação de trabalhadores, estão as atividades industriais ligadas à extração, transformação e construção).

Por outro lado, nota-se que a pendularidade intermunicipal de trabalhadores em direção a Macaé não está restrita a municípios vizinhos. Este trabalho indica que, por conta da necessidade de especialização da força de trabalho exigida pelas atividades petrolíferas, uma parte dos trabalhadores migra de outras localidades mais distantes, como é o caso da capital fluminense. Porém, em decorrência da distância, não o fazem diariamente. Existe, portanto, mais um tipo de migração pendular em Macaé, a de frequência semanal. 
$\mathrm{Na}$ tentativa de tornar plausível a possibilidade de se comprovar a pendularidade semanal, utilizaram-se dados da única empresa rodoviária que disponibiliza o serviço entre a capital do Rio de Janeiro e a cidade de Macaé: a frequência das partidas dos ônibus nos dois sentidos durante os dias úteis. No sentido "Rio x Macaé", foram analisadas as partidas em um intervalo de cinco horas no período da manhã (das 3:00h às 8:00h) e, no sentido "Macaé x Rio", foram analisadas as partidas no intervalo de cinco horas no período da tarde (das 14:00h às 19:00h).

Tabela 2 - Partidas dos ônibus entre Rio de Janeiro e Macaé

\begin{tabular}{|c|c|c|c|}
\hline \multicolumn{2}{|c|}{ Sentido: Rio de Janeiro x Macaé } & \multicolumn{2}{|c|}{ SENTIDO: Macaé x Rio de Janeiro } \\
\hline $\begin{array}{c}\text { Partidas normais: } \\
2^{2} \text { a } 6^{\mathrm{a}} \text { feira }\end{array}$ & $\begin{array}{l}\text { Partidas extras: } \\
\text { Somente } 2^{a} \text { feira }\end{array}$ & $\begin{array}{c}\text { Partidas normais: } \\
2^{\underline{a}} \text { a } 6^{\underline{a}} \text { feira }\end{array}$ & $\begin{array}{l}\text { Partidas extras: } \\
\text { Somente } 6^{a} \text { feira }\end{array}$ \\
\hline- & 3:00h & $14: 10 h$ & - \\
\hline $3: 30 h$ & - & $14: 30 h$ & - \\
\hline- & 3:50h & - & 15:00h \\
\hline 4:00h & - & $15: 10 h$ & - \\
\hline- & $4: 20 h$ & - & $15: 20 h$ \\
\hline- & $4: 41 \mathrm{~h}$ & $15: 30 h$ & - \\
\hline 5:01h & - & - & $15: 40 h$ \\
\hline- & 5:20h & - & $15: 50 h$ \\
\hline $5: 30 h$ & - & 16:10h & - \\
\hline- & $5: 40 h$ & $16: 20 h$ & - \\
\hline $5: 41 \mathrm{~h}$ & - & $16: 30 h$ & - \\
\hline 6:01h & - & - & 16:40h \\
\hline 6:30h & - & - & 17:00h \\
\hline $6: 50 h$ & - & 17:10h & - \\
\hline 7:01h & - & - & 17:20h \\
\hline $7: 41 \mathrm{~h}$ & - & $17: 30 h$ & - \\
\hline- & $7: 50 h$ & 18:10h & - \\
\hline 8:00h & - & 18:30h & - \\
\hline
\end{tabular}

O total de ônibus que deixam o Rio de Janeiro em direção a Macaé é $63 \%$ maior nas segundas-feiras de manhã, em relação aos outros dias da semana, principalmente em horários que permitem os trabalhadores chegarem ao destino antes da abertura das empresas. Pois, às onze partidas normais são somadas sete partidas extras. O mesmo número ocorre na sexta-feira, porém, no sentido contrário e no período da tarde. Significa, portanto, que o número de pessoas que se dirige a Macaé no início da semana e que deixa a cidade nos fins de semana, utilizando o transporte rodoviário, é 63\% superior ao normal; ou seja, há uma mobilidade pendular de mão de obra de frequência semanal polarizada pela cidade média de Macaé e que atinge municípios da Região Metropolitana, uma vez que os ônibus que saem da capital também recolhem passageiros nos municípios de Niterói, São Gonçalo e Itaboraí. Há, portanto, um "fluxo pendular que não só tem ampliada sua escala espacial de deslocamento como também apresenta uma escala temporal de pendularidade estendida" (PAGANOTO: 2008, 17).

\section{5- CONSIDERAÇÕES FINAIS}

O rápido crescimento de uma cidade é repleto de complexidades e contradições, e entre elas estão o recrutamento de pessoas qualificadas aos novos postos e a atração de trabalhadores que se deslocam em busca de oportunidades, ainda que sem certezas. Ademais, o fenômeno migratório em Macaé torna-se ampliado e ressalta a necessidade de análises sobre a sua realidade que se aproxima sistematicamente das características de um município metropolitano.

A cidade média de Macaé convive com eventos de ordem espacial dos mais diversos e, boa parte deles, está relacionada ao fato 
dela ser o destino da migração de milhares de pessoas. Entre esses movimentos, estão as migrações definitivas para Macaé e para os municípios vizinhos. Os dados mostram que as cidades que cresceram juntamente com a atividade petrolífera, o fizeram mais pela chegada de novos residentes do que propriamente pelo crescimento vegetativo. Há, portanto, pessoas que migraram para Macaé e lá permaneceram. Porém, há aquelas que migraram pela atividade, mas decidiram residir em outras cidades e fazem diariamente a mobilidade pendular até 0 trabalho. E, ainda, há o grupo de trabalhadores que, mesmo envolvidos com as atividades do ramo extrativista, residem nas suas cidades de origem, sejam elas nas outras regiões do estado ou até mesmo do país.

O presente trabalho pretende mostrar a influência de Macaé junto aos municípios vizinhos, evidenciando-a como uma cidade média que centraliza e aglomera serviços e cria dependências, polarizando as demais. Porém, considerou-se necessário apresentar que o poder de alcance dessa polarização exercida por Macaé está além das municipalidades próximas. Talvez pelo específico tipo de economia em que ela

\section{REFERÊNCIAS}

[1] Beaujeu-Garnier, Jacqueline. Geografia urbana. Tradução de Raquel Soeiro de Brito. $2^{\underline{a}}$ ed. Lisboa: Fundação Calouste Gulbenkian, 1997.

[2] Castello Branco, M. L. Cidades Médias no Brasil. In: Sposito, E. S; Sposito, M. E. B.; Sobarzo, O. (Orgs.) Cidades médias: produção do espaço urbano e regional. São Paulo: Expressão Popular, 2006.

[3] Corrêa, Roberto Lobato. Estudos sobre a rede urbana. Rio de Janeiro: Bertrand Brasil, 2006.

[4] Costa, Eduarda Marques da. Cidades Médias: Contributos para sua definição. Revista Finisterra, Lisboa, ano 37, v. 47, p. 101-128, 2002.

[5] La Blache, Paul Vidal de. Las divisiones fundamentales del territorio francés. Madri: Alianza Editorial, 1982.

[6] Lacoste, Yves. A Geografia - Isso serve, em primeiro lugar, para fazer a guerra. Campinas: Papirus, 1988.

[7] Mota, Ailton; Pontes, Carla; Tavares, Érica; Carvalho, Leonardo de; Totti, Maria Eugênia. Impactos socioeconômicos e espaciais da instalação do pólo petrolífero em Macaé, RJ. In: PIQUET, Rosélia; SERRA, Rodrigo (orgs). Petróleo esteja inserida, uma vez que as exigências por qualificação são maiores, Macaé consegue criar tais dependências em municípios mais distantes e até mesmo em outros estados.

Desse modo, uma questão é levantada a partir dessas conclusões. Existem migrações pendulares diárias e semanais para Macaé, contudo, existe um tipo de trabalho exercido na atividade petrolífera que não demanda de residência na cidade sede, bem como nas cidades vizinhas: o trabalho dos embarcados. Estes trabalhadores ficam em média 14 dias em alto mar (nas plataformas), e retornam para o período de descanso de mais 14 dias, também em média, nas suas cidades de origem. Boa parte das pessoas que exercem essas funções trabalha em Macaé (nas plataformas), mas não passa nenhum dia na cidade. Fica, portanto, a análise desse outro tipo de migração como proposta para pesquisas futuras.

O crescimento das cidades e da economia do petróleo cria empregos, mas não necessariamente estabelece vínculos com a dinâmica produtiva local que possam garantir maior variação das atividades, diminuindo a dependência que existe sobre um setor econômico instável e finito.

e região no Brasil: o desafio da abundância. Rio de Janeiro: Garamond, 2007.

[8] Oliveira, Floriano José Godinho de. Reestruturação produtiva: território e poder no estado do rio de Janeiro. Rio de Janeiro: Garamond, 2008.

[9] Oliveira Júnior, Gilberto Alves de. Redefinição da centralidade urbana em cidades médias. Revista Sociedade e Natureza, Uberlândia, n 20, junho de 2008.

[10] Paganoto, Faber. Para quem Macaé cresceu? Mobilidade e trabalho na "capital do petróleo". Trabalho apresentado no XVI Encontro Nacional de Estudos Populacionais, ABEP, realizado em Caxambú - MG - Brasil, de 29 de setembro a 03 de outubro de 2008. Disponível em:

[11] http://www.abep.nepo.unicamp.br/encontr o2008/docspdf/ABEP 2008_1065.pdf. Acessado em 08 de outubro de 2014.

[12] Santos, Angela Moulin S. Penalva. Reestruturação espacial e desenvolvimento local: estudo de caso de sete municípios do interior fluminense. Revista Rio de Janeiro, n 18-19, janeiro e dezembro de 2006.

[13] Santos, Milton. Espaço e Método. Rio de Janeiro: Livraria Nobel, 1985. 
[14] Santos, M. A Urbanização Brasileira. São Paulo: Hucitec, 1993.

[15] Santos, M.; Silveira, M. L. O Brasil: Território e sociedade no início do século XXI. Rio de Janeiro: Record, 2008.

[16] Silva, Andresa Lourenço da. Breve discussão sobre o conceito de cidade média. Geoingá: Revista do Programa de Pós Graduação em Geografia. Maringá, v.5, n.1, p.58-76, 2013.

[17] Souza, Marcelo Lopes de. Os Conceitos Fundamentais da Pesquisa Sócio-espacial. Rio de Janeiro: Bertrand Brasil, 2013.
[18] Sposito, M. E. B. As cidades médias e os contextos econômicos contemporâneos. In: Sposito, M. E. B. (org.). Urbanização e cidades: perspectivas geográficas. Presidente Prudente: UNESP, 2001.

[19] Sposito, M. E. B. Novos conteúdos nas periferias urbanas nas cidades médias do estado de São Paulo, Brasil. Revista Investigaciones Geográficas, Boletín del Instituto de GeografiaUNAM, Cidade do México, n.54, 2004. p. 114-139 


\section{Bapítulo 6}

\section{ARRANJOS INSTITUCIONAIS HIBRIDOS E OS PROJETOS DA COPA DO MUNDO FIFA 2014 NA REGIÃO METROPOLITANA DO RECIFE (RMR): UMA ABORDAGEM SITUACIONAL ATÉ O ANO DE 2017}

\section{José Geraldo Pimentel Neto}

Keilha Correia da Silveira

Flavio Antônio Miranda de Souza

\section{Ana Cláudia Rocha Cavalcanti}

Resumo: O presente trabalho tem como objetivo principal discutir a importância do governo estadual na formação de arranjos institucionais híbridos (relação entre o público e o privado) para desenvolvimento e gerenciamento dos projetos relacionados à Copa do Mundo FIFA 2014 na Região Metropolitana de Recife (RMR). Para isso verifica-se a matriz de responsabilidade e os portais da transparência (Federal e Estadual) para os indicadores de mobilidade urbana, infraestrutura aeroportuária, a arena de Pernambuco (estádio) e as ações voltadas para o turismo, até o ano de 2017. Esses indicadores possibilitaram a interpretação, resultados e conclusões sobre o processo de modificação e (re)estruturação da RMR por conta desse grande evento. Direcionando o debate para o gerenciamento urbano-regional das parcerias público-privadas (PPP) ou simplesmente das ações entre o público e privado que normalmente viabilizam o empreendedorismo urbano que tem como foco o planejamento estratégico, transformando a cidade-região (ou parte delas) em uma mercadoria que poderá interagir com os grandes agentes globais, viabilizando novas formas de articulação e de desenvolvimento econômico para essas localidades.

Palavras-chave: Arranjos Institucionais; Copa do mundo FIFA 2014; RMR.

${ }^{*} O$ presente artigo integra o projeto de pesquisa intitulado Desenvolvimento urbano e regional: mudanças e desafios nos arranjos institucionais e territoriais para a Copa do Mundo FIFA de 2014, na RMR, financiado pela FACEPE, e desenvolvido por pesquisadores, bolsistas graduação e doutorando de Pernambuco 


\section{INTRODUÇÃO}

O Brasil, a partir de 1988, promove uma mudança na administração integrada, o estado é fragmentado possibilitando a geração de articulações com outros agentes institucionais. Essa "nova" realidade de interações e articulações é denominada arranjos institucionais, na qual se destacam as relações híbridas (pública e privada). Com esse novo formato constitucional, os governos locais-estaduais assumem um papel importante na coordenação, liderança e tomada de decisão, mobilizando agentes institucionais governamentais (municipais, estaduais, federais e supranacionais) e não governamentais (empresas locais, regionais e globais, terceiro setor, entre outros) que tem como objetivo estabelecer processos de gerenciamento em diferentes focos de atuação, atuando em diversos interesses (recíprocos e/ou estratégicos) para essas localidades.

O estado de Pernambuco está inserido nessa nova realidade de articulação gerencial que pode ser verificado pela sua participação como um dos estados sedes para os eventos da Copa das Confederações de 2013 e da Copa do Mundo FIFA de 2014, foram planejadas diversas obras estruturantes, principalmente, para a Região Metropolitana do Recife (RMR), onde inclusive foi construído a Arena de Pernambuco no município de São Loureço da Mata. Nesse contexto, o presente artigo busca discutir a importância do governo estadual na formação de arranjos institucionais para desenvolvimento e gerenciamento dos projetos relacionados à Copa do Mundo FIFA 2014 na RMR.

Para tanto, adotou-se uma metodologia mista que se convencionou chamar de pesquisa multimétodos, sendo utilizado o método de pesquisa indutivo. Quanto aos procedimentos metodológicos foram estabelecidas três etapas. Etapa I: Pesquisa bibliográfica e documental. Orientada para localizar e revisar textos científicos, relatórios e entrevistas, sobre arranjos institucionais, Copa do Mundo FIFA 2014. Etapa II: Coleta de dados estatísticos. Dirigida para a construção de um banco de dados secundário, utilizado como base para leitura preliminar do perfil socioeconômico, da infraestrutura e dinâmica da RMR e dos projetos relacionados à Copa do Mundo FIFA 2014. Etapa III: Análise dos dados e interpretação. Etapa final dos procedimentos metodológicos, que permitiu a análise comparativa dos dados e a produção do artigo, além de subsidiar as análises do projeto relacionado.

\section{OS ARRANJOS INSTITUCIONAIS NA NOVA GESTÃO PÚBLICA}

A partir da constituição de 1988, a gestão pública incorpora de forma gradativa um modelo mais gerencial com o intuito de otimizar os processos de maneira eficiente e eficaz. Trata-se de um modelo que minimiza a burocracia nas instituições públicas federais, estaduais e municipais. O tema se insere em um debate ideológico sobre estado mínimo, sobre o papel do Estado na gestão da economia.

A preocupação explicita por teóricos e governo é a capacidade gerencial e de execução das políticas públicas pelo Estado, considerando o cumprimento dos princípios administrativos da gestão pública (legalidade, impessoalidade, moralidade, publicidade e eficiência ${ }^{27}$ ) e a relação com os atores afetados na tomada de decisão, na promoção da accountability ${ }^{28}$ e no controle de resultados. (PIMENTEL, 2017)

Nessa discussão, os arranjos institucionais ganham força, uma vez que permitem que instituições democráticas interajam com os atores envolvidos para desenvolvimento das políticas públicas de forma rápida e eficiente. Esses arranjos institucionais são compreendidos como sendo:

- conjunto de regras, mecanismos e processos que definem a forma particular como se coordenam atores e interesses na implementação de uma política pública específica. São os arranjos que dotam o Estado de capacidade de execução de seus objetivos. Ou, em outras palavras, são os arranjos que determinam a capacidade do Estado de implementar políticas públicas. (GOMIDE e PIRES, 2014, p. 20).

Assim, o Estado deverá possuir as habilidades necessárias para implementar seus objetivos. Ele detém as capacidades

27 O princípio da eficiência foi inserido na Constituição Federal de 1988, a partir da Emenda Constitucional no 19, e permitiu flexibilizar a articulação público-privado. (BRASIL, 1988)

28 É um termo da língua inglesa, que remete à obrigação de membros de um órgão administrativo ou representativo de prestar contas a instâncias controladoras ou a seus representados. Outro termo usado numa possível versão portuguesa é responsabilização 
técnico-administrativas e políticas derivam das relações entre as burocracias do Poder Executivo com os atores dos sistemas representativos que podem ser instituições de cunho privado. Essa afirmativa está representada a seguir.

Figura 1 - Modelo Analítico Adotado Para Analisar Os Arranjos Institucionais

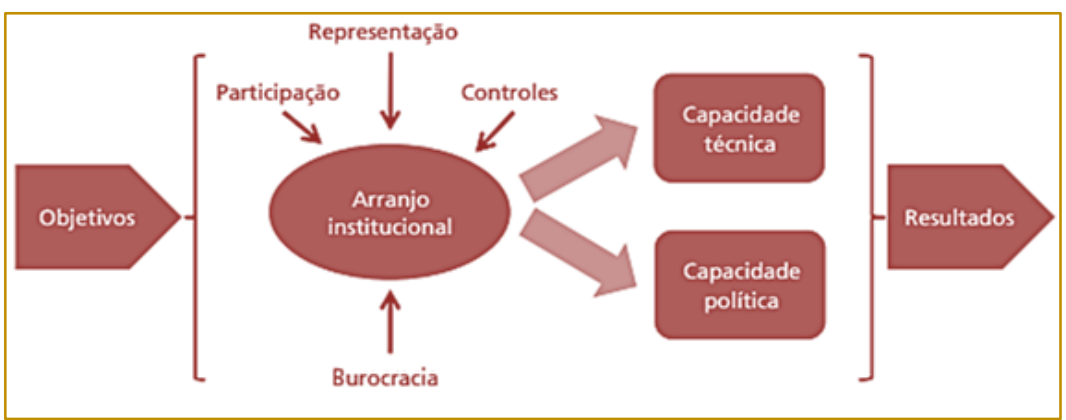

Fonte: Gomide e Pires (2014)

Nesta atual fase da gestão pública, os arranjos institucionais são grandes articuladores e detentores dos grandes projetos urbanos territoriais do país. Essa articulação entre público e privado promoveram diversas ações públicas nos últimos anos. E uma delas foi a Copa das Confederações de 2013 e a Copa do Mundo FIFA de 2014 que ocorreram no Brasil.

Uma primeira análise das possibilidades e efeitos da Copa do Mundo FIFA, Betarelli Junior et al (2011) enfatiza que os benefícios econômicos que serão trazidos por esse evento é de difícil estimação, pois existem muitas ações correlacionadas tais como: obras de infraestrutura urbana, reformas/construção de estádios, fluxos turísticos, investimentos privados (rede hoteleira, por exemplo) e divulgação internacional do país.

Domingues et al (2011) indica que os organizadores geralmente alegam que eventos, como a Copa do Mundo FIFA, geram estímulos para os negócios domésticos (ex.: restaurantes, hotéis e outros negócios) e, portanto, benefícios econômicos maiores que os custos. Um exemplo, segundo o autor, foi o que aconteceu com o comitê organizador da Olimpíada de Atlanta que estimou um impulso de $\$ 5,1$ bilhões na economia e um aumento de 77.000 empregos (BARCLAY, 2009).

Essa compreensão será desenvolvida a partir de agora, pois serão identificadas as obras da Copa do Mundo de 2014 na RMR, desenvolvendo a análise da matriz de Responsabilidades para as seguintes áreas: mobilidade urbana, Infraestrutura Aeroportúaria, Estádio e Turismo. Tentando relacionar o que se imaginava desenvolver pelo projeto da Copa do Mundo FIFA de 2014 na RMR e comparar com o que de fato, até o momento, foi feito (desenvolvido).

Para uma melhor identificação dos projetos será desenvolvido uma apresentação sequencial de todas as obras, com seus respectivos arranjos institucionais, tendo como foco uma breve análise do que se era imaginado desenvolver (antes do período) e a atual situação dos projetos.

\section{O CONTEXTO POLÍTICO-ECONÔMICO DE PERNAMBUCO}

O Estado de Pernambuco liderou os indicadores econômicos no nordeste brasileiro com um crescimento de 5,4\% do PIB da indústria, no terceiro trimestre do ano de 2011, superando o índice nacional que ficou em $1 \%$ e as respostas negativas do Estado do Ceará, com -6,2\%, e da Bahia, com $-1,7 \%$ (CEPLAN, 2012). Outros indicadores confirmam o crescimento econômico de Pernambuco, registrado no início da década de 2010 e por meio da dinamicidade da agenda de políticas públicas voltada para a diversificação setorial e interiorização do crescimento econômico do estado, num contexto muito virtuoso para atração de investimentos e de constantes presenças nas discussões nacionais e internacionais.

Por exemlo, o estado foi objeto de análise em um artigo na revista internacional The Economist em 2012 que mostrou justamente sua importância econômica e a potencialidade do crescimento econômico diante das especificidades regionais do 
estado. Este cenário pernambucano foge de uma regra globalizada, que segundo Fiori (2005) as escalas intermediárias entre o local e o global não possuem tanta força no desenvolvimento e gestão das ações públicas.

Fatores históricos de formação territorial ajudam a explicar a importânica e centralidade de Pernambuco na escala regional (Nordeste), e em alguns aspectos nacional. Destaca-se a capacidade de atração de mercadorias, serviços e pessoas, de Recife, a capital do estado, que polariza as capitais Maceió-AL, João Pessoa-PB e NatalRN (REGIC, 2007). Enquanto infraestrutura, a malha rodoviária do estado é ponto de passagem para, praticamente, todo fluxo de carga vinda do Centro-Sul do país.

Mais recentemente, as relações políticas do estado com o governo nacional merecem destaque, principlamente por que estas impulsionaram significativamente 0 crescimento econômico do estado, registrado no início da década de 2010. Foi prioritariamente num contexto político que grandes projetos estruturais foram concluídos e/ou iniciados.

A política federal de maior expressão em Pernambuco é representada pelo Programa de Aceleração do Crescimento - PAC I e II, que aportou investimentos de $\mathrm{R} \$ 31$ bilhões, até o ano de 2010, e, aproximadamente, $\mathrm{R} \$ 32$ bilhões, para os anos seguintes, para projetos de desenvolvimento do Estado como: estradas, portos, ferrovias, hidrovias, aeroportos, abastecimento, irrigação, energia elétrica, revitalização de bacias e entre outros.

Abaixo estão indicados os principais investimentos no Estado de Pernambuco entre 2007 a 2010.

Figura 2 - principais investimentos do programa de aceleração do crescimento (pac) no estado de pernambuco, entre os anos de 2007 a 2010.

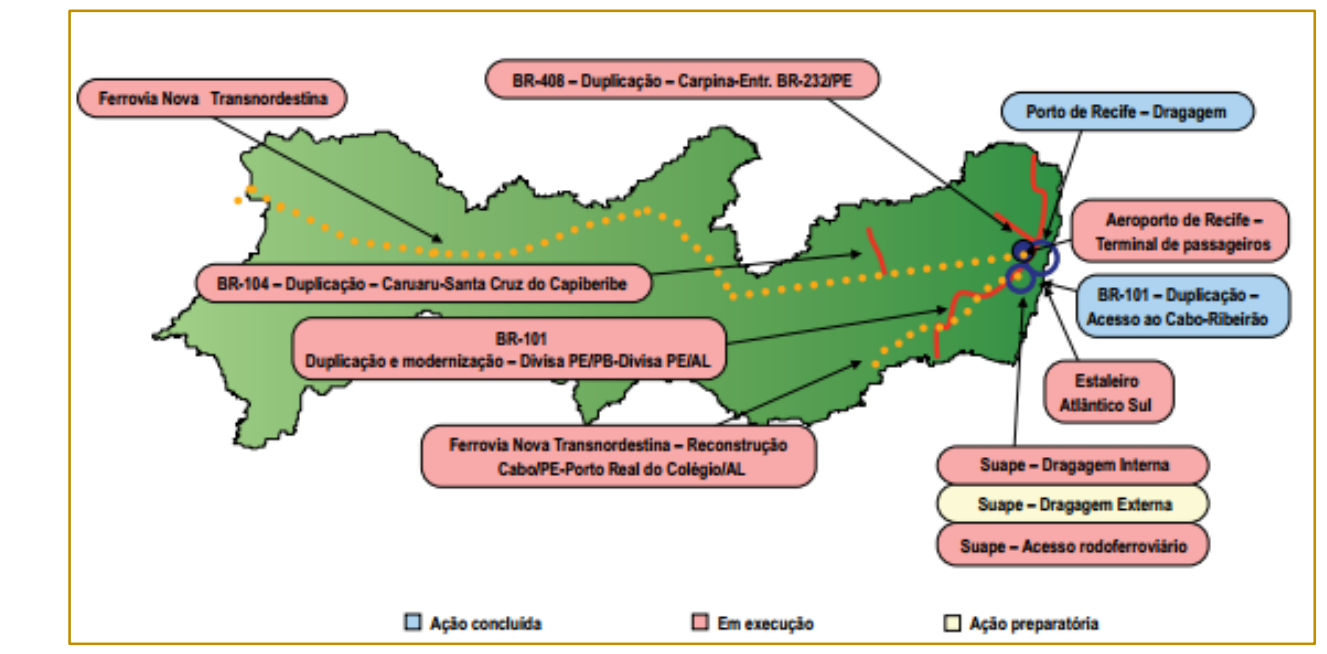

Fonte: http://www.pac.gov.br/pub/up/relatorio/e57c8636825fc69302e23b82a01c6282.pdf

Destaca-se alguns empreendimentos: (i) $\mathrm{O}$ Porto de SUAPE é um dos maiores complexos portuários do país, apresenta estrutura moderna, com profundidades entre $15,5 \mathrm{~m}$ e $20,0 \mathrm{~m}$ e grande potencial de expansão. Sua localização estratégica em relação às principais rotas marítimas de navegação o mantém conectado a mais de 160 portos em todos os continentes, com linhas diretas da Europa, América do Norte e África. Ele está situado na RME, possui área de 13.500 hectares, distribuída em zonas Portuária, Industrial, Administrativa e Serviços, de
Preservação Ecológica e de Preservação Cultural.

(ii) A Refinaria Abreu e Lima localizada nas proximidades de Suape, no qual suas estruturas físicas estão com mais de $75 \%$ de implementadas. Conforme estabelecido no Plano de Negócios da Companhia, que prevê investimentos totais de US\$236,7 bilhões para o período 2013-2017, a refinaria será um dos grandes parceiros, junto com Suape, para o desenvolvimento do setor de metalmecânica do Estado de Pernambuco. 
(iii) Fábrica da Fiat que concluiu os estudos para instalação de sua unidade industrial no município de Goiana-PE, e será a segunda da empresa no Brasil. Este empreendimento tem como objetivo ser um polo automotivo altamente integrado. A fábrica da Fiat poderá produzir entre 200 mil e 250 mil unidades por ano, com investimentos entre $R \$ 3$ bilhões e $\mathrm{R} \$ 3,5$ bilhões. O número de empregos diretos deve superar os 3,5 mil postos inicialmente projetados. O acionamento da linha de produção previsto para o início de 2014, foi realizado em 2015 com o nome da marca Jeep.

(iv) Arco Metropolitano, obra de estruturação estão sendo desenvolvidas para melhorar as conexões viárias do Estado de Pernambuco visando o desenvolvimento territorial da RMR, dentro de uma lógica econômica e social, que gere benefícios aos residentes, à economia local, à economia do setor público e possibilite a integração das cadeias industriais e dos processos logísticos de forma eficiente e competitiva. Sua função principal é aumentar a mobilidade dos fluxos de cargas e pessoas em um eixo viário, tangenciando toda a RMR e integrando três grandes estruturas de desenvolvimento econômico: complexo Portuário de SUAPE, Refinaria Abreu e Lima, no Litoral Sul, e a empresa FIAT, no Litoral Norte. Resumindo, está obra facilitará a integração entre a RMR e todos os seus principais empreendimentos localizados nesta área.

Além das ações já mencionadas, o governo do estado teve investimento de recursos específicos para o desenvolvimento econômico dos Arranjos Produtivos Locais $(\mathrm{APL})$, pelo Ministério de Desenvolvimento Indústria e Comércio Exterior (MDIC). Trata-se de políticas públicas de grande potencial de desenvolvimento, pois são estimuladas pelo ambiente político-institucional e pelos fatores de competitividade, complementaridade e cooperatividade sistêmica da economia localregional do estado de Pernambuco.

Segundo o MDIC, entre 2007 e 2008, o estado possuía 7 APL (Lacticínio, fruticultora, gesso, tecnologia da informação, confecções, apicultura e caprinovinocultura). Em 2010, Moutinho (2010) identifica 14 APL, na listagem/mapeamento estadual, que recebem algum tipo de ajuda institucional, sendo que oito deles recebem políticas específicas de APL e seis claramente recebem um tipo de apoio equivocado com um desenho de política voltado para o setor ou, na melhor das hipóteses, para a cadeia produtiva. (MOUTINHO, 2010, p.4)

Essa estrutura para o apoio aos APLs de Pernambuco tem na sua base diversos agentes que atuam na execução de programas ou ações pontuais, são eles: Governos Federal e Estadual, Prefeituras, entidades do Sistema S, associações, cooperativas, sindicatos, federações, instituições de C\&T, ONGs e empresas.

Visto toda infraestrutura e ações no Estado de Pernambuco (implementadas e em desenvolvimento), além de grandes empresas públicas e privadas é verificado novas oportunidades de crescimento econômico para o Estado. Uma delas foi à participação da Região Metropolitana do Recife como cede da para o grande evento - A Copa do Mundo FIFA de 2014 no Brasil.

\section{MATRIZ DE VIABILIDADE PARA A COPA DO MUNDO FIFA 2014}

(1) Cidade da Copa (1a Smart City da América Latina): de acordo com o RIMA (2012) da Cidade da Copa sua estrutura teria cerca de 240 hectares com um percurso entre qualquer um dos seus polos, terminais integrados de ônibus e metrô, além das faixas exclusivas para pedestres e ciclistas. Essa nova estrutura teria como objetivo, de acordo com o RIMA, criar uma nova centralidade urbana, planejada e adequada às necessidades do Grande Recife, objetivando um novo destino para inovar conceitos e oferecer um novo padrão de qualidade de vida.

Essa era para ser a estrutura da Cidade da Copa na cidade de São Loureço da Mata, Região Metropolitana de Recife (ver figura abaixo). O grande problema no cenário atual é que não há previsão do andamento do projeto sendo uma possibilidade dele nem sair da perspectiva do projeto, ou seja, o projeto ficar como uma obra em um papel. 
Figura 3 - Cidade Da Copa - Smart City

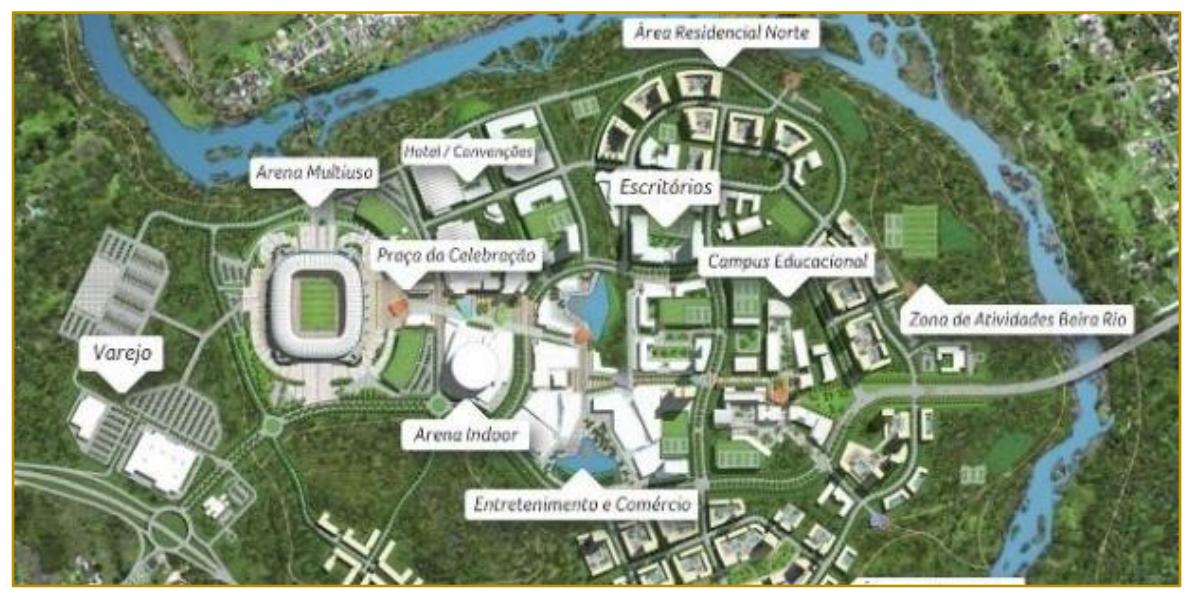

Fonte: http://copadomundo.uol.com.br/noticias/redacao/2014/07/10/no-recife-maior-legado-da-copaespera-licencas-e-so-fica-pronto-em-2030.htm

A justificativa para tal situação é a falta de investimentos, pois como a estrutura é de grande magnitude gera muitos custos para 0 seu desenvolvimento e implementação (Quadro 3). Essa matriz de responsabilidade indica que os arranjos institucionais estavam bem definidos, cada um com suas responsabilidades, mas por conta da falta de recurso a atual situação da cidade da copa no município de São loureço da Mata é de total incerteza, pois não se sabe se o projeto terá continuidade, por este motivo, é a única matriz que foi desenvolvida pelo RIMA.

Quadro 1 - Matriz De Responsabilidade - Cidade Da Copa

\begin{tabular}{|c|c|c|c|c|}
\hline Ação & Fase & Recurso (r\$) & Instrumento & $\begin{array}{l}\text { Arranjo institucional } \\
\text { E responsabilidade }\end{array}$ \\
\hline $\begin{array}{c}\text { Cidade } \\
\text { da } \\
\text { Copa }\end{array}$ & $\begin{array}{c}\text { Em projeto não } \\
\text { se sabe se vai } \\
\text { ser } \\
\text { desenvolvido }\end{array}$ & $\begin{array}{c}\text { Previsão de } \\
1.053 .826 .000\end{array}$ & $\begin{array}{l}\text { Parceria público- } \\
\text { privada (PPP) }\end{array}$ & $\begin{array}{l}\text { - Governo Federal: Financiador } \\
\text { - Governo Estadual: Financiador } \\
\text { e gestão (controle e poder de } \\
\text { polícia) } \\
\text { - Governo municipal: gestão do } \\
\text { uso do solo } \\
\text { - Criação de um Conselho } \\
\text { Gestor da Cidade da Copa (Sem } \\
\text { fins lucrativos - OS) } \\
\text { - Empresa contratada: } \\
\text { Odebrecht e outras de menor } \\
\text { porte (consórcio) }\end{array}$ \\
\hline
\end{tabular}

Fonte: RIMA - Cidade da Copa (2012)

( Pesquisado no sítio - http://www.cprh.pe.gov.br/downloads/RIMA-cidade-da-copa.pdf)

(2) Estádio - Arena Pernambuco: De acordo com o RIMA da cidade da Copa na qual está inserido a Arena Pernambuco a construção e operação da arena é uma Parceria Público Privada (PPP) entre o Governo de Pernambuco e o Consórcio Arena Pernambuco. Essa PPP possui uma concessão de 33 anos, incluindo os três anos de obras e o período de operação do espaço.
O investimento inicial cotado era de aproximadamente de $\mathrm{R} \$ 500$ milhões, porém por conta de diversos fatores gerenciais 0 investimento teve um total de, aproximadamente, $R \$ 900$ milhões, sendo, aproximadamente, $\mathrm{R} \$ 700$ milhões, financiado pelo governo federal. Esse dado pode ser verificado no quadro II que objetiva analisar a matriz de responsabilidade da obra. 
Quadro 2 - Matriz De Responsabilidade - Arena Pernambuco

\begin{tabular}{|c|c|c|c|c|}
\hline Ação & Fase & Recurso $(r \$)$ & Instrumento & $\begin{array}{l}\text { Arranjo institucional } \\
\text { E responsabilidade }\end{array}$ \\
\hline $\begin{array}{c}\text { Arena } \\
\text { Pernambuco }\end{array}$ & Finalizado & $890.835 .424,65$ & $\begin{array}{c}\text { Parceria } \\
\text { público- } \\
\text { privada (PPP) }\end{array}$ & $\begin{array}{l}\text { - Governo Federal Financiamento - } \\
\text { BNDES e BNB } \\
\text { - Governo estadual: executor } \\
\text { - Governo local: gestão do uso do solo } \\
\text { - Empresa contratada: Odebrecht e } \\
\text { outras de menor porte (consórcio) }\end{array}$ \\
\hline
\end{tabular}

(Pesquisado no sítio - http://transparencia.gov.br/copa2014/cidades/home.seam?cidadeSede=9)

Da mesma forma que a cidade da copa a matriz de responsabilidade da Arena Pernambuco apresentou os arranjos institucionais bem definidos (tecnicamente e juridicamente). O seu desenvolvimento foi a partir do instrumento parceria público-privada que tem por objetivo geral atender grandes obras diminuindo as burocracias do poder público. Um ponto positivo, possível de ser verificado na figura III, mesmo pelo fato que tinha de haver os jogos, foi que as obras para - Estádio foram finalizadas para a Copa das Confederações e Copa do Mundo de 2014. Atualmente ela atende a eventos esportivos locais-regionais, na qual o time que usufrui da estrutura é o Clube Náutico Capibaribe.

Nos últimos meses o Governo do Estado de Pernambuco a partir de um estudo da Fundação Getúlio Vargas (FGV) que teve como objetivo analisar os aspectos econômicos do contrato da parceria públicoprivada, seus custos, suas receitas, indicaram como o caminho mais sensato rescisão contratual. Por este motivo o Governo do Estado resolveu romper o contrato de concessão, pois segundo matéria do jornal PE $360^{\circ}$ em março de 2016, ele indicou uma frustração de receitas e da subutilização e manutenção do empreendimento, por isso, foi tomada a decisão de rescindir o contrato.

Outro problema grave que ajudou na decisão de rescisão contratual foi, segundo Estudo desenvolvido pelo Tribunal de Contas do Estado de Pernambuco (TCE), o apontamento de vinte e uma (21) irregularidades no contrato de construção e exploração da Arena Pernambucano. O relatório constatou que foram gastos na obra $R \$ 389$ milhões. Uma diferença de $R \$ 90$ milhões em relação ao gasto calculado pelo consórcio liderado pela Odebrecht ( $\mathrm{R} \$ 479$ milhões).

Essa situação mostra que mesmo os arranjos institucionais estando bem definidos tecnicamente e juridicamente a ação não se desenvolveu adequadamente, pois houve um gasto bem maior que o previsto e ainda existe uma indicação de corrupção entre as partes envolvidas. Por este motivo, é necessário um maior controle (em todo processo) das ações do desenvolvimento do empreendimento, pois este tipo de controle pode evitar perdas e outras atividades inoportunas no processo.

(3) Mobilidade urbana: Talvez um dos maiores problemas da Região Metropolitana do Recife (RMR) seja a mobilidade urbana que, com certeza, seria um dos grandes legados positivos na melhoria das estruturas viárias e transporte público, mitigando os problemas já existentes no que se refere à mobilidade urbana no RMR. As principais obras para a Copa do Mundo de 2014 eram: 1) Obras da Estação de Metrô Cosme e Damião, 2) Obras do Viaduto da BR-408, 3) BRT: Corredor Caxangá (Leste/Oeste), 4) BRT: Norte / Sul Trecho Igarassu / Tacaruna / Centro do Recife, 5) BRT: Leste / Oeste - Ramal Cidade da Copa, 6) Corredor da Via Mangue.

Esses cenários das obras de mobilidade urbana inacabadas já eram identificados por matéria de Barbosa (2014) como uma pesquisa de campo ela verificou que grande parte das obras não ficou pronta para o evento da Copa do Mundo de 2014 e que segundo a matéria só iriam terminar no outro ano - 2015. Essa informação, inclusive, foi admitida pela Secretaria das Cidades de Pernambuco.

Um ano após o evento da Copa do Mundo, Barbosa (2015) e Passo (2015) desenvolveram, um diagnóstico situacional das principais obras relacionadas à mobilidade urbana e o resultado conclusivo foi que boa parte dessas obras ainda estão inacabadas ou se quer adequadas para o uso da população.

Mesmo no momento atual deste artigo, praticamente, todas as estruturas debatidas nas matérias ainda estão inacabadas é 
possível perceber isso a partir do quadro III que indica pesquisa no portal da transparência da Copa do Mundo de 2014 e da imagem de março de 2016 como mostra a figura IV. É de grande importância ressaltar que um dos principais legados da Copa do
Mundo para a população do Grande Recife eram os corredores de BRT Norte/Sul e Leste/Oeste que ainda não foram concluídos, adequadamente. Um exemplo são as estações de integração que ainda não foram concluídas.

Quadro 3 - Matriz De Responsabilidade - Mobilidade Urbana

\begin{tabular}{|c|c|c|c|c|}
\hline Ação & Fase & Recurso (r\$) & Instrumento & $\begin{array}{l}\text { Arranjo institucional } \\
\text { E responsabilidade }\end{array}$ \\
\hline $\begin{array}{l}\text { Estação de } \\
\text { Metrô Cosme } \\
\text { e Damião }\end{array}$ & Inacabada & $26.271 .859,70$ & $\begin{array}{l}\text { Contrato } \\
\text { com o } \\
\text { Governo do } \\
\text { Estado }\end{array}$ & $\begin{array}{l}\text { - Governo Federal: financiador - Caixa } \\
\text { Econômica Federal; } \\
\text { - Governo Estadual: Financiador e } \\
\text { executor } \\
\text { - Governo municipal: manutenção e } \\
\text { gestão do solo } \\
\text { - Jag Empreendimentos LTDA }\end{array}$ \\
\hline $\begin{array}{l}\text { Viaduto da } \\
\text { BR-408 }\end{array}$ & Concluído & $25.000 .000,00$ & & $\begin{array}{l}\text { - Governo Estadual: financiador e } \\
\text { executor (não há outras informações). }\end{array}$ \\
\hline $\begin{array}{l}\text { BRT: Corredor } \\
\text { Caxangá } \\
\text { (Leste/Oeste) }\end{array}$ & Inacabada & $157.612 .163,25$ & $\begin{array}{l}\text { Contrato } \\
\text { com o } \\
\text { governo do } \\
\text { Estado }\end{array}$ & $\begin{array}{l}\text { - Governo federal: financiador - Caixa } \\
\text { Econômica Federal } \\
\text { - Governo Estadual: financiador e } \\
\text { executor } \\
\text { - Governo municipal: gestão do uso do } \\
\text { solo } \\
\text { - Empresa contratada: Mendes Junior } \\
\text { Trading e Engenharia S. A. }\end{array}$ \\
\hline $\begin{array}{l}\text { BRT: Norte / } \\
\text { Sul - Trecho } \\
\text { Igarassu / } \\
\text { Tacaruna / } \\
\text { Centro do } \\
\text { Recife }\end{array}$ & Inacabada & $151.113 .293,56$ & $\begin{array}{l}\text { Contrato } \\
\text { consócio } \\
\text { com o } \\
\text { governo do } \\
\text { Estado }\end{array}$ & $\begin{array}{l}\text { - Governo Federal: financiador - Caixa } \\
\text { Econômica Federal } \\
\text { - Governo Estadual: Financiador e } \\
\text { executor } \\
\text { - Empresa contratada: EMSA Empresa } \\
\text { Sul Americana De Montagens S A }\end{array}$ \\
\hline $\begin{array}{l}\text { BRT: Leste / } \\
\text { Oeste - Ramal } \\
\text { Cidade da } \\
\text { Copa }\end{array}$ & Inacabada & $131.014 .036,10$ & $\begin{array}{l}\text { Contrato } \\
\text { com o } \\
\text { governo do } \\
\text { Estado }\end{array}$ & $\begin{array}{l}\text { - Governo Federal: financiador - Caixa } \\
\text { Econômica Federal } \\
\text { - Governo Estadual: Financiador e } \\
\text { executor } \\
\text { - Empresa contratada: Mendes Junior } \\
\text { Trading e Engenharia S. A. }\end{array}$ \\
\hline $\begin{array}{l}\text { Corredor da } \\
\text { Via Mangue }\end{array}$ & Inacabada & $394.616 .706,44$ & $\begin{array}{l}\text { Contrato } \\
\text { com o } \\
\text { governo do } \\
\text { Recife }\end{array}$ & $\begin{array}{l}\text { - Governo Federal: Financiador - Caixa } \\
\text { Econômica Federal } \\
\text { - Governo do Estado Financiador } \\
\text { - Governo municipal: executor } \\
\text { - Empresa contratada: Construtora } \\
\text { Queiroz Galvão S.A }\end{array}$ \\
\hline
\end{tabular}

Fonte: Portal da transparência (2016) e desenvolvido pelo autor.

Atualmente, ainda existe projetos na área de mobilidade urbana inacabados, um exemplo é o BRT: Corredor Caxangá (Leste/Oeste) que deveria ter suas estações de integração prontas para atender a população, mas nenhuma delas foi finalizada e o pior é que todas estão necessitando de reparos, pois por conta da falta de uso algumas estruturas já estão necessitando de reforma. Outro ponto negativo é que essas estações estão sendo usadas por usuários de droga tornando-a uma região perigosa. Essa situação pode ser verificada na figura IV. 
Figura 4 - Estação Integração Da Caxangá - Recife-Pe

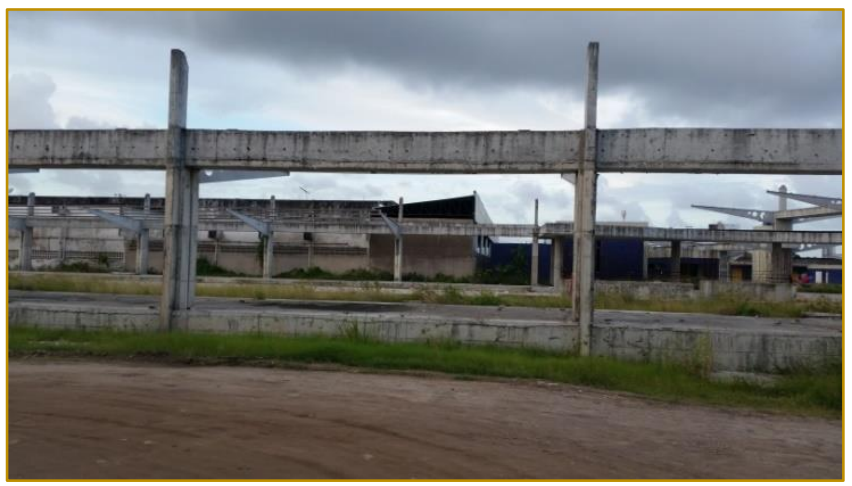

Fonte: próprio autor (2016)

O quadro das matrizes de responsabilidade para mobilidade urbana indica que os seus arranjos institucionais foram adequadamente distribuídos pelas suas funções técnicas e jurídicas, porém somente uma das ações propostas teve sua finalização por completa. E mesmo ela, no portal da transparência, não há muita informação, por este motivo que o quadro III não possui certas informações para essa ação.

As principais obras para melhoria da mobilidade urbana na RMR ainda não terminaram e pior não tendo, atualmente, nenhuma previsão de término. A pergunta que fica é qual foi o grande problema, pois visto que houve a distribuição das respectivas responsabilidades, todas as ações jurídicas para as implementações dos projetos aparentavam estar adequadas, pelo menos é o que indica no portal da transparência. Então qual foi o problema para tanta ineficiência, visto que até na constituição de 1988 existe essa preocupação com a eficiência das ações, já que ela é um dos princípios administrativos.

(4) Infraestrutura Aeroportuária e Turismo: Essas duas ações públicas estão juntas porque no portal da transparência, quadro IV, há certas inconsequências nas informações, por este motivo algumas informações ficaram incompletas e se terá uma maior dedicação para encontrá-las em outro momento da pesquisa. Um exemplo dessa incongruência é a ação instalações complementar para o tema infraestrutura aeroportuária existe a informação do investimento, porém não há nenhuma referência para o que se foi desenvolvido, se suspeita que esteja relacionado à construção da passarela do aeroporto-metrô (figura abaixo). Porém, não há como afirmar essa hipótese visto que não existe nenhuma informação sobre esse empreendimento.

Figura 5 - Passarela de ligação do aeroporto para o metrô

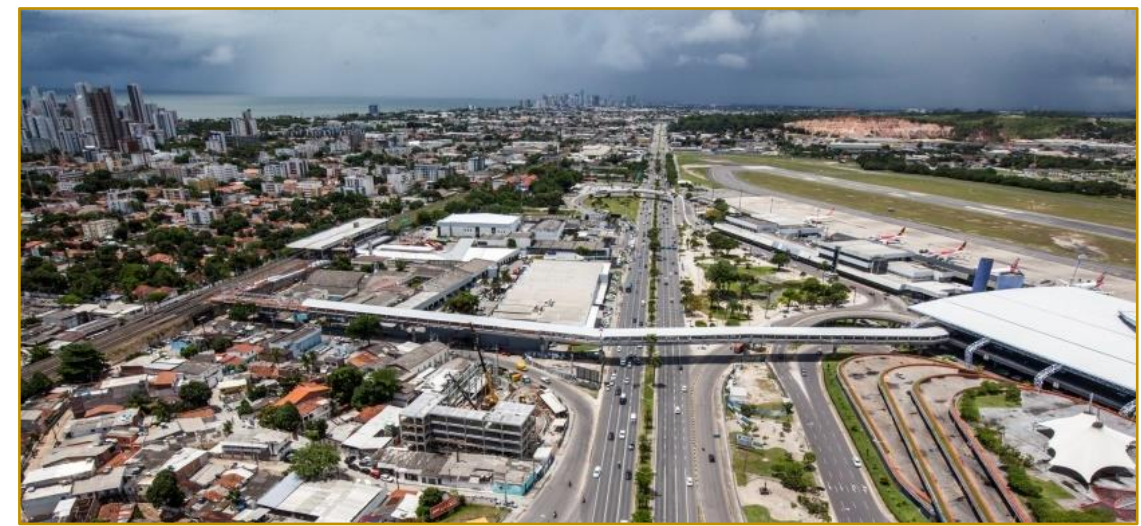

Fonte: https://pt.wikipedia.org/wiki/Aeroporto_Internacional_do_Recife 
No que tange as ações das políticas públicas para a Copa do Mundo de 2014 as grandes referências de investimento são para as infraestruturas de acessibilidade nos atrativos turísticos - Recife; implantação, reforma e adequação de Centros de Atendimento aos
Turistas (CAT) - Recife e Sinalização turística nos atrativos turísticos - Recife. Essas sinalizações estão relacionadas para acessibilidade aos atrativos turísticos na orla de Olinda e foi a ministério do turismo que executou o projeto.

Quadro 4 - Matriz De Responsabilidade - Infraestrutura Aeroportúaria E Turismo

\begin{tabular}{|c|c|c|c|c|}
\hline Ação & Fase & Recurso $(\mathrm{R} \$)$ & Instrumento & $\begin{array}{c}\text { Arranjo Institucional e } \\
\text { responsabilidade }\end{array}$ \\
\hline $\begin{array}{l}\text { Porto do Recife } \\
\text { S/A }\end{array}$ & $\begin{array}{l}\text { Parcialmente } \\
\text { finalizada }\end{array}$ & $28.075 .606,21$ & $\begin{array}{l}\text { Contrato com } \\
\text { o município } \\
\text { do Recife }\end{array}$ & $\begin{array}{l}\text { - Governo Federal: financiador } \\
\text { - Secretaria de Portos da } \\
\text { Presidência da República } \\
\text { - Governo municipal: Porto do } \\
\text { Recife S/A } \\
\text { - Empresa contratada: } \\
\text { Concrepoxi Engenharia Ltda }\end{array}$ \\
\hline $\begin{array}{l}\text { Instalações } \\
\text { complementares }\end{array}$ & Indefinido & 33.900 .000 & & $\begin{array}{l}\text { - Governo estadual: executor e } \\
\text { financiador (não há outras } \\
\text { informações) }\end{array}$ \\
\hline $\begin{array}{l}\text { Acessibilidade } \\
\text { nos atrativos } \\
\text { turísticos - Recife } \\
\text { (Olinda) }\end{array}$ & $\begin{array}{c}\text { Não } \\
\text { concluído }\end{array}$ & $\begin{array}{l}487.500,00 \\
\text { (projeto) } \\
7.000 .000,00 \\
\text { (obra) }\end{array}$ & & $\begin{array}{l}\text { - Governo Federal: financiador } \\
\text { e executor - ministério do } \\
\text { turismo } \\
\text { - Empresa contratada: } \\
\text { Colmeia Arquitetura e } \\
\text { Engenharia. LTDA (projeto) } \\
\text { - TEP Construturoa LTDA - } \\
\text { EPP (Obra) }\end{array}$ \\
\hline $\begin{array}{l}\text { Adequação de } \\
\text { Centros de } \\
\text { Atendimento aos } \\
\text { Turistas (CAT) }\end{array}$ & $\begin{array}{c}\text { Não } \\
\text { concluído }\end{array}$ & 499.200,00 & $\begin{array}{l}\text { Contrato com } \\
\text { o governo } \\
\text { municipal do } \\
\text { Recife }\end{array}$ & $\begin{array}{l}\text { - Governo federal financiador- } \\
\text { Ministério do turismo } \\
\text { - Governo municipal - executor } \\
\text { - Empresa contratada: GR } \\
\text { Projetos e Empreendimentos } \\
\text { IMOBILIÁRIOS LTDA }\end{array}$ \\
\hline $\begin{array}{l}\text { Sinalização } \\
\text { turística nos } \\
\text { atrativos } \\
\text { turísticos (Olinda } \\
\text { e São Lourenço } \\
\text { da Mata) }\end{array}$ & $\begin{array}{c}\text { Não } \\
\text { concluído }\end{array}$ & $3.000 .000,00$ & $\begin{array}{l}\text { Contrato com } \\
\text { o governo } \\
\text { Estadual }\end{array}$ & $\begin{array}{l}\text { - Governo federal financiador- } \\
\text { ministério do turismo } \\
\text { - Governo Estadual: executor - } \\
\text { secretaria de turismo } \\
\text { - Empresa contratada: SN } \\
\text { Sinalizadora Nacional e Serviços } \\
\text { LTDA }\end{array}$ \\
\hline
\end{tabular}

Fonte: Portal da transparência (2016). O organizado pelos autores.

O quadro de responsabilidade indica que algumas ações na área do turismo e aeroportuária não foram desenvolvidas e que algumas delas não possui todas as informações no portal da transparência os arranjos institucionais em quase todas as ações estão bem definidos, porém isso não significou um bom desenvolvimento das políticas públicas na área do turismo, visto que boa parte das ações não foram concluídas, algumas já possuem determinadas implementações, porém nenhuma delas na sua totalidade.

Um ponto importante dessas identificações no portal da transparência foi que em muitos dos casos o recurso não foi usado na sua plenitude e, logicamente, que os produtos que deveriam ser entregues também não foram desenvolvidos em sua totalidade. Um exemplo são os casos das sinalizações para o Estádio que deveriam ser uma constante na RMR, porém não há essa referência, indicando que houve ineficiência no uso, gestão e aplicação dos recursos nessa ação de política pública na área do turismo.

Essa uma constância para todos os temas dos empreendimentos para a Copa do mundo. Na verdade, é preciso verificar qual o motivo de tanta ineficiência entre esses 
arranjos institucionais, qual é a instituição ${ }^{29} \mathrm{de}$ maior culpa? Qual é a mais eficiente e qual é a menos eficiente? Esses questionamentos ajudarão a entender o motivo das políticas públicas não funcionarem, pois mesmo com essa articulação entre o público (com suas diversas escalas) e o privado não é verificado uma maior eficiência entre a proposta do projeto e sua implementação.

\section{CONSIDERAÇÕES FINAIS}

O entendimento do que sejam os arranjos institucionais se torna essencial na gestão pública porque a maioria das articulações (ações de política pública) entre as instituições dependerá de um arranjo institucional. Além disso, outro ponto relevante ao debate é a forma como se gerenciam hoje os projetos na administração pública Atualmente, de acordo com Linhares (2012), a dinâmica do Estado federativo, na nova gestão pública ${ }^{30}$, é impulsionada por mecanismos de responsabilidade e accountability em todas as esferas governamentais. Por este motivo, é de estrema importância entender os arranjos institucionais, pois serão eles que desenvolverão as políticas públicas do país.

Analisando especificamente as matrizes de responsabilidade a partir do portal da transparência da Copa do Mundo é possível afirmar, de forma geral, que os empreendimentos que tem como o Estado (nível estadual de execução), normalmente, para o caso na Copa do Mundo de 2014 em Pernambuco, as informações ficam a desejar, detalhando, ou ficam faltando informações na

\footnotetext{
${ }^{29}$ Segundo North (1991) instituições são: consistem de duas restrições informais (sanções, tabus, costumes, tradições e códigos de conduta) e regras formais (constituições, leis, direitos de propriedade). Ao longo da história, as instituições foram criadas pelos seres humanos para criar ordem e reduzir a incerteza em troca. Junto com as limitações normais da economia, eles definem o conjunto de escolhas e, portanto, determinar a transação e os custos de produção e, consequentemente, a rentabilidade e a viabilidade de se engajar em atividade econômica. (NORTH, 1991, p.1).

30 A nova gestão pública teve início a partir dos anos setenta do século passado, nos Estados Unidos, Inglaterra, Canadá, Austrália, entre outros. Segundo Aragão (1997) houve uma crítica/crise ao modelo econômico/financeiro vigente da época, que era voltado a uma gestão pública burocrática weberiana.
}

própria página ou ficam faltando materiais (documentos) para se ter uma melhor análise dos usos dos recursos no projeto. Os dois melhores exemplos são: 1) em infraestrutura aeroportúaria (Instalações complementares) e 2) mobilidade urbana (Viaduto da BR-408).

Em contrapartida as melhores informações estão, para o caso da Copa do Mundo de 2014 em Pernambuco, no nível do município (nível municipal de execução). Os exemplos são: 1) turismo (Adequação de Centros de Atendimento aos Turistas (CAT)) e Mobilidade urbana (avenida via mangue). Em ambos os casos se há a informação e diversos documentos do processo e controle nas ações do empreendimento. Porém, isso não quer dizer que as ações foram desenvolvidas adequadamente, o ponto, nesta questão, é no processo da difusão da informação que é um dos principais pontos do portal da transparência.

De todos os processos analisados apenas dois foram finalizados. O primeiro, por motivos óbvios, é o estádio a Arena de Pernambuco e outro foi o viaduto da BR 408. Mas, isso não quer dizer que os processos foram eficientes, em pelo menos um dos casos, a Arena da Copa de Pernambuco, é possível fazer a seguinte verificação; o seu custo previsto era de $R \$ 532.600 .000,00$, porém se gasto foi de $\mathrm{R} \$$ 890.835.424,65. Indicando, no mínimo, uma péssima análise de planejamento para definição de uma obra.

Por fim, se devem responder algumas perguntas: qual é a instituição de maior culpa nesse processo? Qual é a mais eficiente e qual é a menos eficiente? Os arranjos institucionais são eficientes e a solução para a gestão pública no país? Essas perguntas vão permear ainda, por um bom tempo, mas um ponto importante e que para os próximos grandes projetos ou mesmo os de menor magnitude, é preciso implementar uma forma adequada de controle, que permeei todo processo e seus monitoramentos e avaliações sejam feitos rotineiramente. Acredito que desenvolvendo dessa forma a eficiência tão procurada na gestão pública chegará para os projetos de política pública no país. 


\section{REFRÊNCIAS}

[1] Aragão, C. V. de. Burocracia, eficiência e modelos de gestão pública: um ensaio. Revista do Serviço Público - RSP, Nº 3, 1997.

[2] Barbosa, M. Prometidas para a Copa, obras de mobilidade ficam para 2015 em PE. G1 PE. 2014.

[3] Barbosa, M. Um ano após a Copa, Pernambuco tem 4 obras de mobilidade inacabadas. G1 PE. 2015.

[4] Barclay, J. Predicting the costs and benefits of mega-sporting events: mis judgement of olympic proportions? Economic Affairs, v. 29, n. 2, p. 62-66, jun. 2009.

[5] Brasil. Constituição Federal de 1988. Constituição da República Federativa do Brasil. Brasília, DF: Senado. 1988.

[6] Domingues, E. P.; Betarelli JUNIOR, A. A.; Magalhaes, A. S. Quanto Vale o Show? Impactos Econômicos dos Investimentos da Copa do Mundo 2014 no Brasil. Estudos Econômicos (USP. Impresso), v. 41, p. 409-439, 2011.

[7] Fiori, José Luís. O poder global e a nova geopolítica das nações. São Paulo: Boitempo, 2007.

[8] Fudação Getúlio Vargas. Elaboração de estudos que promovam aprimoramentos do programa estadual de parcerias público-privadas, a partir do caso da concessão administrativa para exploração para a arena multiuso da Copa de 2014. 2015.

[9] Gomide, A.A.; PIRES, R.R.C. (Org.). Capacidades estatais e democracia: arranjos institucionais de Políticas públicas. 1. ed. Brasília: IPEA, v. 1, p.385, 2014.
[10] Harvey, David. Condição Pós-Moderna: uma pesquisa sobre as origens da mudança cultural. 6 ed. São Paulo: Loyola, 1996.

[11] Ibge - Instituto Brasileiro De Geografia e Estatística. Regiões de influência das cidades 2007. Rio de Janeiro, 2008.

[12] Linhares, P.T.F.; Mendes, C.C.; Lassance, A. (Org.) Federalismo à Brasileira: questões para discussão. 1. ed. Brasília: IPEA, v. 1, p.249, 2012.

[13] Melo, Marcus Andre. Crise federativa, guerra fiscal e hobbesianismo municipal. In: M. Guedes. (Org.). Política e Contemporaneidade no Brasil, p. 11-143, 1997.

[14] Moutinho, L. M. G. Análise do mapeamento e das políticas para arranjos produtivos locais no Norte, Nordeste e Mato Grosso e dos impactos dos grandes projetos federais no Nordeste. 2010.

[15] North. D.I. The Journal of Economic Perspectives, Vol. 5, No 1.(Winter, 1991), p. 97-112, 1991.

[16] Pires Advogados e Consultores (2012). Relatório de Impacto Ambiental - RIMA: Projeto Cidade da Copa. 2012. Disponível em: http://www.cprh.pe.gov.br/downloads/RIMAcidade-da-copa.pdf. Acessado em: 20/03/2016.

[17] Sportv. TCE: Arena Pernambuco custou $\mathrm{R} \$ 90$ mi a menos que dito por empreiteira. SporTV. Rio de Janeiro. 2016.

[18] The Economist. The Pernambuco model. Disponível em: <http://www.economist.com/news/americas/215652 27-eduardo-campos-both-modern-manager-andold-fashioned-political-boss-his-success>. Acesso em 30 out. 2012. 


\section{Capítulo 7}

\section{UMA GEOGRAFIA HISTÓRICA URBANA/REGIONAL DA PROVINCIA FLUMINENSE}

\section{Valter Luiz de Macedo}

Resumo: O texto, que analisa aspectos da formação territorial fluminense no período imperial brasileiro, reforça a premissa de que uma análise de fato geográfica dos espaços deve incorporar uma dimensão também temporal visto que toda forma social é produto historicamente construído em um espaço e que este, a cada momento, denota processos de diferentes expressões de tempo. A pesquisa entende que analisar o território fluminense durante o século XIX, quando se institui no Brasil um projeto nacional, significa observar como determinadas frações desse território passaram a configurar espaços diferenciados no contexto político, econômico e social da província, notadamente em seu viés urbano. E como premissa, adota a ideia de que o projeto nacional pretendido, de lastro fundamentalmente territorial, considera o espaço citadino como mecanismo articulador de esferas regionais. É, neste sentido, que o texto associa os conceitos de cidade e região em suas discussões sobre uma possível geografia histórica do atual estado do Rio de Janeiro.

Palavras-chave: Província fluminense, cidade e região, geografia histórica 


\section{INTRODUÇÃO}

O período imperial brasileiro marcou $\mathrm{O}$ surgimento de um projeto de Nação que, realizado pelas elites políticas e econômicas, mantinha as características estruturais da sociedade colonial a exemplo da centralização do poder, da forte desigualdade de classes, da manutenção de privilégios e, sobretudo, da escravidão. Tal período deve ser visto como um momento em que se forja uma unidade nacional através da formação de uma hierarquia brasileira de valores e pela nobilização dos senhores rurais agrupados em torno do Imperador. Este arranjo sociopolítico determinou uma ordem imperial marcada por um Estado conservador que via no território o elemento de coesão das elites e no mote ideológico de "construção da nação" a retórica para a manutenção do controle tanto da unidade quanto do controle territorial nas formas até então consagradas.

A manutenção efetiva da unidade territorial do império pressupunha o seu efetivo controle, sobretudo, em se tratando de uma imensa extensão física ocupada de forma descontínua ao longo do tempo. Para além das atividades de ordem econômica assentada na produção agrícola, a gerência do espaço interno e o controle de suas relações e fluxos nos moldes pretendidos passaram a ser uma questão essencial para a própria manutenção de um poder centralizado como o foi o monárquico no Brasil. É, nestes temos, que nosso trabalho sinaliza para uma política imperial voltada para o fortalecimento da unidade territorial através da instituição de vilas e cidades como base levada à prática quando da configuração adotada pelo emergente espaço nacional.

Investigamos, portanto, o uso político das cidades (ou assentamentos urbanos de natureza e magnitude distintas) que passam a ser tomadas como centros do exercício de tais funções (no plano administrativo e de controle) e como nós na rede de comunicações e transportes que havia de ser montada nos padrões estabelecidos pelo nível técnico disponível na época pelo império brasileiro. Falamos aqui de uma rede de assentamentos urbanos com funções específicas (repetimos: rede incipiente, é bem verdade, mas integradoras uma vez que possibilitavam as comunicações pretendidas naquele momento) como forma de regulação e controle sobre uma dada região e de um projeto nacional visto como ações territoriais nestas escalas geográficas em essência.
Pensamos que a província fluminense, entorno imediato da capital imperial, demanda estudos sobre a relação cidade e região no contexto da política territorial do Império brasileiro. Dados dão conta de que a área do atual Estado do Rio de Janeiro, que até o fim do período colonial contava com 15 núcleos urbanos, registrava na década de 1890 um total de 48 , além de uma série de "fixos" instalados em seus distintos centros urbanos que vão se constituir em "centralidades" no território que se apropriava. Tais números precisam ser investigados. E investigados de maneira a considerar as especificidades do estudo sobre o espaço em tempos pretéritos.

\section{O TEMPO NOS ESTUDOS GEOGRÁFICOS}

Buscando alinhar-se aos debates mais recentes no campo da Geografia Histórica, este texto reforça a premissa de que uma análise de fato geográfica dos espaços incorpora necessariamente uma dimensão também temporal visto que toda forma social é produto historicamente construído em um espaço e que este, a cada momento, denota processos de diferentes expressões de tempo. No falar de Santos (2004, p. 159), inclusive, "a simultaneidade das diversas temporalidades sobre um pedaço da crosta da Terra é o que constitui o domínio propriamente dito da Geografia". Por isto, não apenas a pertinência mas a própria necessidade de se considerar as relações entre espaço e tempo no âmbito da Geografia como um todo em seu exercício de análise dos espaços geográficos.

Neste sentido, e na linha do que indicou Abreu (2014), pontuamos que, ao se estudar o espaço no tempo pretérito, é importante adequar para o entendimento do passado as variáveis que operacionalizam as categorias de análise da Geografia (estas sim universais), contextualizando os processos estudados através tanto da análise do que se produziu sobre eles (nos recortes temporal e espacial adotados) quanto da investigação necessária às fontes primárias de informação (entendendo-as sempre como fragmentos da realidade e como narrativas de poder).

Tais pontos configuram, portanto, a busca por um "enquadramento espaçotemporal" sugerido pelo referido autor para os estudos do espaço no tempo para que tal quadro referencial possa ser efetivamente analisado à luz dos conceitos e variáveis trazidos como adequados à pesquisa geográfica pretendida. 
Em outras palavras, não é apenas a recuperação das formas morfológicas e dos "fixos" (Santos, 2004) construídos no espaço que deve basear tal pesquisa. Para além da sua dimensão material, o que deve iluminar os estudos (mesmo diante das dificuldades inerentes) é a compreensão do que o referido autor chamou de "dimensão dos comportamentos obrigatórios" que são, em última análise, as formas jurídicas e sociais vigentes numa dada sociedade e em um dado tempo.

Neste caminho a ser seguido por pesquisas históricas em Geografia, de imbricação da materialidade do espaço com os processos em distintas escalas temporais, há de se destacar o papel instrumentalizador das técnicas humanas (desiguais no decorrer do tempo e entre distintas sociedades, inclusive, em um mesmo momento histórico) como necessidade colocada para tais estudos.

Está na base da Geografia como ciência renovada e crítica a consideração de que é através do uso das técnicas que, de fato, a relação entre homem e meio se estabelece. $\mathrm{E}$ isto independe do tempo analisado, variando sobremaneira em sua complexidade. Assim, é correto formular a premissa de que as técnicas (desde as mais simples) são os meios através dos quais os homens historicamente estabelecem seus processos e formas de vida, estabelecem meios de subsistência ou de produção econômica avançada, estabelecem enfim formas específicas de produção do espaço em última análise. E este caráter é fundamental para os estudos de geografia histórica uma vez que "as técnicas, de um lado, dão-nos a possibilidade de empiricização do tempo e, de outro lado, a possibilidade de uma qualificação precisa da materialidade sobre a qual as sociedades humanas trabalham" (Santos, 2004, p. 54).

É este o caminho que adotamos na pesquisa: uma tentativa de "empiricização" do tempo através do levantamento dos "fixos" construídos no espaço em momento pretérito (documentados em fontes primárias e secundárias de informação) como possibilidade de sistematização e compreensão de características, discursos e ideias vigentes no recorte temporal tomado como objeto de pesquisa.

No contexto que efetivava a ideia de construir a nação como ocupação do solo, investigamos se os núcleos urbanos (ou alguns) constituídos no território denotavam fins regionais, buscando perceber os marcos administrativos e/ou de serviços que conferiam "centralidade" a alguns núcleos urbanos na província fluminense: comarcas, distritos eleitorais, freguesias, mercados, sedes policiais, tribunais, escolas/liceus, hospitais, fluxos, etc..

Junto ao desafio de levantamento de tais formas materiais do/no espaço, interessa-nos também a compreensão sobre determinados aspectos do contexto social e discursivo da época para discutirmos, à luz de uma Geografia Urbana e Regional em perspectiva histórica, o que tornava, naquele tempo e de fato, um núcleo urbano central (se assim o podemos dizer) ou, em outras palavras, importante em um dado recorte territorial, elencando elementos importantes para o estudo sobre a gênese do território fluminense a partir do entendimento de um arranjo espacial fruto de um plano regional de urbanização.

\section{REDE URBANA NO TEMPO PASSADO}

Observar teoricamente a constituição das cidades brasileiras em momentos pretéritos, no que diz respeito às suas características e relações, não é tarefa elementar. O arcabouço conceitual sobre o tema e sobre a área do conhecimento humano em que ele está inserido apenas se institucionaliza a partir do final do século XIX. Lembremos, por exemplo, que na tradição geográfica, são numerosos os estudos sobre hierarquia e natureza das redes urbanas. No entanto, tais questionamentos apenas foram colocados a partir das primeiras décadas do século passado e têm na "Teoria dos Lugares Centrais", elaborada por Christaller por 1933, sua principal referência teórica. Assim, a despeito do fato de que muitos autores têm dado contribuições importantes para as discussões, a questão dos conceitos a serem considerados para a análise das formações urbanas do passado continua posta.

No contexto de uma ex-colônia que se torna Império quando o mundo, liderado por forças econômicas provenientes do continente europeu, caminha para a afirmação e expansão do capitalismo em sua fase industrial, tomamos a cidade como um ponto do espaço geográfico que, considerada expressão de controle sobre um território conquistado e símbolo de poder, avança na apropriação dos excedentes agrícolas, 
canalizando e controlando a produção rural rumo à sua exportação. Mais: se seguirmos Corrêa (2006) e utilizarmos o termo "rede urbana" como o conjunto de núcleos urbanos funcionalmente articulados entre si ou a um núcleo principal através de acessos materializados no território, poderemos falar em uma "divisão territorial do trabalho" que enfatiza o papel da rede urbana através das funções de suas cidades.

$\mathrm{Na}$ rede, cada cidade assume um papel específico, através de diferentes modos e intensidades, e a sua existência tornar-se-á inviabilizada quando este papel, por um motivo qualquer, não puder mais ser desempenhado ou deixar de ser necessário.

Essencial para nosso estudo é perceber, nos moldes definidos pelo autor em tela, que as cidades no Brasil configuraram desde o início um modelo espacial mais simples de rede urbana geralmente orientada pela rede fluvial existente e caracterizada pela primazia de única cidade e sua hinterlândia. Assim, para Corrêa (2006), há de se constatar que tanto mediações e fluxos pouco complexos neste modelo de rede acabam por beneficiar a cidade principal em detrimento de outras quanto o fato de que a herança deixada no espaço pela forma dendrítica original da rede urbana no Brasil não desapareceu totalmente com o padrão mais complexo que o processo evolutivo da organização espacial da rede urbana brasileira viria a tomar.

Tais considerações reforçam nosso objetivo de estudos. Em nosso olhar sobre o Brasil do passado, um caminho metodológico que nos parece oportuno relaciona cidade e região através dos circuitos ou redes "dendríticas" criadas entre os núcleos que emergiam no território, mostrando como determinada cidade espelhou a região em que estava inserida e, por outro lado, como determinadas regiões refletiram a ação dos atores hegemônicos urbanos a elas associados.

Quando se pensou em um projeto nacional para o Brasil, as redes criadas desempenharam papel primordial na unidade territorial e na articulação do Império ao circuito econômico que se mundializava. Através de sua função de intermediação, podemos olhar as redes urbanas regionais como parte da divisão internacional do trabalho visto que, no contexto das sociedades modernas, a rede urbana foi a forma espacial adotada para a criação, apropriação e circulação do excedente ou, em outras palavras, para a viabilização dos ciclos de exploração da economia capitalista (ibdem).

$\mathrm{Na}$ escala regional, há de se observar que muitas cidades não tardaram em funcionar como local de consumo da renda fundiária, uma vez que pelo fato dos proprietários rurais nela residirem, parcela importante do valor excedente produzido no campo era transferida para o ambiente urbano. Exatamente, neste ponto, reforçamos a importância de estudos em geografia histórica que analisem a estruturação do território a partir das redes estabelecidas em diferentes tempos como expressão da drenagem da renda fundiária no Brasil, estudo este que necessariamente põe lado a lado a ação do Estado e das oligarquias rurais com a configuração espacial resultante e condicionante de tais relações.

Sabemos que a constituição de uma rede urbana brasileira ocorreu de forma muito lenta nos quatro primeiros séculos, ao ritmo da exploração do vasto território e caracterizada por baixas densidades. Apenas no XIX, esta dinâmica sofre alterações significativas. Assim, tomamos o território fluminense e sua sociedade nobiliárquica e estratificada como realidade para nossos estudos sobre a estruturação de um território no que se refere às relações estabelecidas através dos sistemas de transportes implantados e da natureza dos núcleos urbanos que surgem no contexto da política territorial do Império brasileiro.

\section{IMPÉRIO BRASILEIRO: UNIDADE E CONTROLE DO TERRITÓRIO}

A apropriação do ideário de nação moderna pelas elites políticas e econômicas brasileiras no período imperial consubstancia uma percepção de país associado apenas ao seu território e tal retórica contextualiza as práticas de base territorial também no caso da província fluminense. Moraes (2005, 97), a esse respeito, sentencia que "ali onde a história pouco fornece para a elaboração de uma identidade regional, os argumentos de índole geográfica vão possibilitar a elaboração de discursos legitimadores onde o país é visto como um espaço, e mais, um espaço a ser conquistado e ocupado". Ressalta-se a importância das ideias e das ações políticas. 
No caso brasileiro, a idéia de "imaginação" é central como ferramenta explicativa da construção ideológica e material da nação no que diz respeito, sobretudo, às concepções de patriotismo e ao estabelecimento das fronteiras do Império. Parece-nos que tal idéia confirma, por exemplo, a expressão "comunidade imaginada" de Anderson (1989).

No que concerne à fundação imaginária e simbólica da nacionalidade brasileira lembremos de Marilena Chauí quando nos fala que "para realizar tal tarefa, o poder político precisa construir um semióforo fundamental, aquele que será o lugar e o guardião dos semióforos públicos. Esse semióforo-matriz é a nação" (Chauí, 2000, p. 14). Neste sentido, ressaltamos que o poder político utiliza a ideia de nação para produzir uma unidade pretendida, inclusive, para a sociedade a ser integrada por valores que emanariam, por exemplo, da escola, do patrimônio histórico e geográfico e artístico a ser construído a exemplo dos monumentos celebratórios previamente pensados.

Antes de qualquer coisa, semióforo é imagem e representação e, como fica evidente nas palavras da autora, o poder político aparece como agente principal na sua produção e reprodução. A questão dos mitos neste processo também merece ser observada e, neste sentido, devemos pensar a construção da nação brasileira como um processo de escolha de narrativas e de mitos a serem contadas como organizadores da nossa história.

Destas considerações, constatamos o papel central do Estado na construção da narrativa da nação brasileira e, assim, confirmamos a assertiva de Hobsbwm (1990) na qual "as nações não fazem Estados e nacionalismo, mas o contrário". A esse respeito, Graham (1997), ao observar em parte de seu livro a questão dos Estados-nacionais no contexto da América Latina, reafirma que "a nação não teria existido sem o Estado, que o moldou através dos séculos XIX e XX" e ainda repete que o mesmo ocorreu no subcontinente como um todo.

Sobre a centralização no Brasil promovida pelo Estado, Barman (1988) declara que a unidade nacional foi, em grande parte, criada por um governo central e Sérgio Buarque de Holanda destaca que "a unidade nacional (...) estará ao ponto de esfacelar-se nos dias que imediatamente antecedem e sucedem à proclamação da Independência. Daí por diante irá fazer-se passo lento de sorte que só em meados do século pode dizer-se consumado" (Holanda, 1962, p. 16).

A despeito dos movimentos separatistas e revolucionários no Império, foi notória a união dos interesses dos senhores de terras e da economia ao poder central e, para a compreensão deste fato, vale registrar o argumento trazido por Mattos (1994). O autor se concentra no período de meados da década de 1830 até o início da década de 1860 e postula um bloco de fazendeiros de café recentemente enriquecidos, da região do Rio de Janeiro, liderados por um pequeno grupo de políticos/estadistas ativos, ou saídos daquele bloco ou ligados a ele por laços de casamento, esforçando-se com sucesso para absorver líderes de outras regiões, formando uma classe única. Esta classe se definia por sua oposição a outras classes, especialmente aos escravos, mas também à plebe urbana rude e inquieta. Para ele, essa classe senhorial abraçou uma ideologia da ordem desenvolvida e defendida por advogados, juízes, jornalistas, professores, médicos, empresários, políticos e burocratas, isto é, os "intelectuais orgânicos" (conceito trazido por Gramsci). Através do próprio processo de formação de uma classe poderosa que dominava todo o Brasil, prossegue o autor, emergiu um forte Estado centralizado. Mattos entende esse Estado não como um simples aparato coercitivo, mas como um instrumento de orientação intelectual e moral. Por meio dele, a classe senhorial construiu sua própria unidade e expandiu seu poder, tanto horizontalmente, por todo o território brasileiro, quanto verticalmente sobre maiores segmentos da população livre, não impondo a submissão, mas incorporando esses grupos à "civilização". Assim, através da aceitação de um Estado centralizado foi a premissa para a formação de uma nação. Interesses materiais e econômicos forjaram um Estado centralizado e a unidade nacional pretendida no discurso imperial.

Seguindo Moraes (2005), lembremos que, nos países de formação colonial, a dimensão espacial adquire considerável importância na explicação de suas dinâmicas históricas, pois a colonização é um processo em si que relaciona sociedade e espaço. A partir desta lembrança e das mudanças anunciadas e discutidas até aqui, destacamos que a questão da unidade territorial, necessidade da nação como "semióforo", sugere que argumentos de índole geográfica possibilitam 
discursos legitimadores do Brasil como espaço a ser conquistado. E esta necessidade perseguida coloca em evidência uma outra face do processo: a que nos mostra que o padrão discursivo básico do século XIX estruturou-se em torno do conceito de "civilização" e da empreitada monárquica que se imbuiu de uma missão civilizadora. E, nesta nova frente, o papel dos núcleos urbanos é mais uma vez essencial. Eles passariam a ser tomados como espaço dos semióforos desejados mais do que simples pontos de conexão de uma rede para articulação regional e do Império como um todo.

Martins (2005) revela como um outro viés importante, o jurídico-institucional, nos ajuda a entender a monarquia constitucional brasileira a partir de um longo processo de organização de uma autoridade central no qual a instituição do Conselho de Estado desempenhou papel fundamental. Este Conselho, estudado pela autora, foi responsável pela montagem da estrutura jurídico-administrativa que fortaleceu as bases do Estado Imperial, constituindo-se em espaço de negociações, acomodação dos conflitos e conciliação de interesses das elites. Para ela, a compreensão das ações e do comportamento das elites imperiais brasileiras (que não representavam um todo uno nem um grupo isolado) pode ser alcançada através da análise da dinâmica desta instituição e da identificação de suas redes de sociabilidade e parentesco que eram estruturalmente confirmadas a cada momento. Em última análise, os membros do Conselho de Estado integravam diferentes grupos de relacionamentos que se perpetuavam e se constituíam desde o século anterior baseados em grupos familiares tradicionais e suas alianças clientelistas (poderes regionais submetidos ao poder central). Gravitando, assim, em torno dos cargos mais importantes, a elite brasileira em suas diferentes representações acabava por sustentar o equipamento do Estado, tornandoo a sua própria razão de ser. Vale enfatizar aqui que, nesta lógica, a população, de uma forma geral, foi pensada apenas como instrumento do processo, e não o próprio objetivo da nação.

Resta-nos reafirmar o papel representado pelos núcleos urbanos com espaço preferencial para a manifestação e reprodução dos semióforos nacionais ante ao projeto proferido como uma de suas funções mais importantes a ser compreendida. Dito isto, resta-nos também considerar a observação clássica da cidade como nó articulador de uma rede regional e/ou nacional. E, neste sentido, destacamos o seu caráter regional como profícuo caminho para a compreensão das determinações históricas analisadas até aqui em seu rebatimento no território fluminense.

\section{APONTANDO DINÂMICAS URBANO- REGIONAIS NA PROVIINCIA FLUMINENSE}

Vimos afirmando que a unidade de controle territorial alvejada pelo poder central era, em essência, a região. E esta era atingida, na prática, através das cidades e redes para que, subjugadas, tais porções maiores do espaço viessem a se tornar realmente território imperial. Cabe aqui, portanto, elencar algumas das medidas de ordenamento territorial vigentes na província (a exemplo das freguesias e comarcas) e as principais dinâmicas econômicas desenvolvidas no território fluminense no período imperial (notadamente as questões do café e do açúcar), bem como a importância dos caminhos para "fluidez" no território e, sobremaneira, o a instituição das grandes propriedades de terra na província. Comecemos pela questão dos "fundos territoriais" (no dizer de Moraes, 2005) que congregaram elites e impuseram dinâmicas espaciais importantes.

A partir de 1821, com o fim deste regime de sesmarias e a transformação de boa parte das capitanias em províncias, abre-se um hiato na atividade legislativa sobre as terras no Brasil que se prolonga até a Lei de Terras de 1850. Neste intervalo, observou-se uma progressiva ocupação do solo sem qualquer título e mediante a simples tomada da posse, por vezes através da força e refletindo a forte presença dos senhores na sociedade da época.

A este momento, uma das grandes discussões entre a elite imperial era a escolha dos critérios que definiriam a repartição dos territórios de maneira a contemplar os poderes do Estado, da Igreja e entes econômicos, salvaguardando o discurso dos interesses nacionais. Em termos administrativos, o grande território foi dividido, como dissemos, em províncias e a este tempo também foi legitimada a divisão dos territórios em freguesias, atendendo às estruturas eclesiásticas de poder que vinham do período 
colonial, em comarcas, unidades de controle jurídico, e em distritos, para fins eleitorais.

De tradição colonial no Brasil, as freguesias passaram a se configurar como uma unidade elementar da partilha e da administração pública, sendo dotada de autoridade militar e policial e de relativa autonomia jurídica. Cada uma delas, também denominada de paróquia, recebia o nome de um santo católico e seu poder se expressava pela influência ideológica da Igreja e, economicamente, pela produção agrícola, pastoril e de serviços, além do acúmulo de propriedades imobiliárias dos grandes senhores de terra localizados sob sua jurisdição. Se no início do século XIX, já se podia falar em pelo menos 46 freguesias instaladas na província do Rio de Janeiro, Chrysóstomo (2006) nos mostra que este total chegara a 81 no ano de 1849 e a 119 em 1870.

Tal expansão nos mostra a necessidade de especialização das medidas de administração territorial e, neste sentido, é importante tecermos algumas considerações sobre a Lei de Terras de 1850. Através dela, legitimava-se a aquisição pela posse no Brasil, mas esta apenas teria validade, isolando-se do domínio público, se levada ao Registro do Vigário, livro de notas da paróquia ou freguesia em que a terra estava localizada. Entre outros tantos aspectos importantes, cabia, portanto, ao pároco das freguesias do Império a indicação das terras que passariam a ser consideradas privadas e aquelas chamadas de devolutas ou do patrimônio das províncias, vindo daí o caráter obrigatório do registro e a importância administrativa das freguesias.

Quanto às comarcas, é sabido que foram instituídas pelo Código de Processo Criminal de 16 de dezembro de 1832, que extinguiu os Juízes Ordinários e estabeleceu a seguinte estrutura para cada uma delas: um Juiz Municipal, um Promotor Público, um Conselho de Jurados, um Escrivão das Execuções e demais oficiais. Como expressão de força das elites ao redor do Imperador, é importante observarmos que, para o caso do Ministério Público, uma lista tríplice deveria ser apresentada pelas Câmaras Municipais para que os promotores fossem nomeados por um período de três anos pelo governo na Corte e pelos presidentes de província.

Tal decisão passou a ser ainda mais centralizada através da reforma do Código de Processo Criminal de 03 de dezembro de 1841, quando os promotores não seriam mais indicados por lista elaborada pelas Câmaras Municipais, mas seriam diretamente nomeados pelo Imperador ou pelos presidentes de província para cargos agora com tempo indeterminado. Além do mais, cada comarca contaria agora com apenas um promotor e não mais quantos fossem os seus termos. Apenas nos casos das comarcas mais importantes, poderia haver a nomeação de mais de um promotor.

Segundo o CIDE (1988), se ainda no início de século XIX existiam apenas as comarcas de Rio de Janeiro, Ilha Grande, Paraíba Nova, Cantagalo, Cabo Frio e Campos dos Goytacases, em um total de 6, este número passou para 9 em 1835 (com o novo arranjo territorial, surgem novas denominações como Resende, Vassouras, Angra dos Reis, Município Neutro, Niterói e Itaboraí) e para 13 em 1866 (a nova configuração faz surgir comarcas como a de São João Príncipe, Magé e Estrela), denotando subdivisões sucessivas do território que, pelo crescimento em importância, deveria ser administrado de forma mais próxima. Para Fridman (2005), "esse aumento do número de comarcas pode ser interpretado como uma preocupação por parte do Governo Provincial com a gestão política, judiciária, fiscal e militar do território fluminense, isto é, com uma divisão regional atrelada ao surto urbano."

Neste contexto, eram os municípios mais importantes que funcionariam como "cabeça de comarca" e teriam sua influência mais uma vez confirmada sobre determinadas regiões da província. E o processo de criação de novas comarcas e elevação do status de determinados núcleos urbanos seguia a ponto de Chrysóstomo (2006) indicar que, em 1885, já eram 25 as comarcas instaladas na província. Delas, além da Corte, destacavamse, sem dúvida alguma, a de Campos dos Goytacazes e a de Vassouras.

Tecidas estas considerações até aqui, é importante observarmos que municípios realmente se destacavam neste território em expansão (visto que assumiriam funções de primazia na rede urbana que se estruturava, refletindo, segundo nossa análise, a forma através da qual o Império organizava administrativamente a Nação). Também se faz necessária a análise do processo de ocupação das terras do interior fluminense desde o seu início, durante o século XVIII, quando da atividade mineradora no interior da Colônia. 
Atendo-se ao caso do Vale do rio Paraíba do Sul, observamos que a ocupação se deu pela "empresa povoadora" controlada direta ou indiretamente pelo Estado que visava a conquista do solo para satisfação do mercado interno e estrangeiro. Com objetivos similares, e partindo da cidade do Rio de Janeiro ou chegando até ela, importantes caminhos desenhavam o mapa das comunicações estabelecidas até então entre a Capital e sua hinterlândia, seja em traçado "direto" rumo às minas (através de localidades como Petrópolis e Três Rios, por exemplo) ou mais "circulares" como os que atingiam São Paulo ou os que exploravam o baixo curso do rio Paraíba do Sul, na atual região norte do Estado.

Fridman (1999) indica a importância de tais caminhos no estabelecimento de comunicações e fluxos de mercadorias entre diversas localidades, enfatizando que eles foram abertos por particulares por cláusula nas cartas de sesmarias e, em muitos casos, aproveitavam o traçado derivado de antigas vias de circulação indígena. Ressaltou também que, por estes caminhos, surgiram aglomerados, pontos de feiras periódicas, vilas, cidades, sítios, fazendas, além de outras estradas tributárias, e que a prática de abertura de novas vias de circulação se intensificou com a atividade cafeeira.

Observamos que um comércio de gêneros alimentícios e de animais que, originário das Minas Gerais se articulava com o Rio de Janeiro, originou um setor de subsistência mercantil também responsável pela ocupação do interior fluminense. Os recursos e os caminhos das tropas tiveram destaque na expansão da economia cafeeira e de seus valores sociais. Por estas vias de penetração, fornecia-se à capital considerável parte dos gêneros agrícolas que consumia, circulavam informações e estabeleciam-se engenhos produtores de açúcar e as primeiras fazendas de café. A articulação entre produção e comércio, viabilizada pelo crescente número de caminhos propiciou inclusive a formação de núcleos de povoamento, como já dito.

Desta forma, podemos entender que, desde os primórdios da ocupação e exploração do território fluminense, as atividades realizadas encontravam como eixo principal as estradas coloniais, tendência que persistiu durante 0 século XIX quando as grandes fazendas cafeicultoras (no Vale do Paraíba), o dinamismo açucareiro (na "região" de Campos dos Goytacazes) passaram a desempenhar papel de referência no "mapa das interações possíveis", ostentando a riqueza que sustentou o Império. $\mathrm{Na}$ contrapartida, áreas da província como o litoral sul (Angra dos Reis e Parati) viveu momento de decadência e isolamento com a abertura das novas dinâmicas econômicas e seus correspondentes eixos espaciais. Como já havíamos apontado, ocorreu com esta porção sul da província o caso em que a importância de uma cidade em uma dada rede tornar-se inviabilizada quando seu papel, por um motivo qualquer, não pode mais ser desempenhado ou deixa de ser necessário.

Sobre estas questões, ressaltamos a articulação de um capital fundiário brasileiro e um capital produtivo internacional para a construção de ferrovias que viriam agilizar a produção e consolidar uma infraestrutura de transportes. O ponto a ser considerado é aquele que marca um processo de integração entre distintas regiões, entre produção e comércio, potencializado pelo advento das ferrovias, mas não iniciado através delas. As vias de circulação e de comunicação, mesmo que mais lentas, já estavam delineadas como testemunho da lógica social, política e econômica em vigor no território em tempos pretéritos. No entanto, e o caso fluminense nos mostra, a "rede" pensada e estabelecida não fugia de sua definição teórica e afirmava seu caráter seletivo do espaço tornado território.

É Fridman (2005) quem busca indicar a ocupação territorial de caráter planejado na região fluminense conhecida por "sertão d'oeste", que teve sua expansão no período associada ao café e que compreendia as localidades de Resende, Paraíba do Sul, Piraí, Paty do Alferes, Sacra Família do Tinguá, Vassouras, Mendes e Miguel Pereira. Para ela, tal planejamento, consubstanciado em um projeto de colonização, está reportado também à fundação de comarcas que compuseram a hinterlândia da cidade do Rio de Janeiro. $E$, nestes termos, propõe uma volta ao tema urbanização articulado a projeto de colonização.

Após lembrar a "onda" colonizadora desta parte do território fluminense por obra da chamada "civilização do café", com nítido plano regional de urbanização que avançava a interiorização já pensada desde metade do século XVIII ainda por Portugal, a autora enfatiza que "durante o século XIX alterações territoriais ocorreram através da política oficial de povoamento vinculada a interesses 
particulares da exploração agrícola" (Fridman, 2005). E complementa com precisão tais características do processo que marcamos aqui quando se refere ao Vale do Paraíba fluminense como representativo da "expansão da fronteira agrícola através dos latifúndios, da violência dos brancos contra os escravos negros e nativos, da fundação de colônias de parcerias e da criação de freguesias, vilas e comarcas como polos de poder político" (ibdem).

Destacamos ainda que, neste contexto de afirmação cafeeira, os eixos dinâmicos da economia fluminense (e nacional) partiam da cidade de Rio de Janeiro e se dirigiam para Resende (no sertão d'Oeste), para São Gonçalo (no sertão do leste) e para Cantagalo, nas serras do centro-norte $d$ a província. Ao longo dos caminhos abertos, a expansão da fronteira agrícola dinamizava as economias regionais, fazendo, inclusive, expandir os contingentes urbanos e suas atividades.

Sobre a questão específica do trato do território neste momento, é fundamental destacar que a marca da espontaneidade dos lugares, registrados em diversos pontos do território, cede vez para uma ação cada vez mais planejada. Fala-se agora em um aparato burocrático que alia companhias de colonização e grandes proprietários fundiários de forma que novos pontos do território vão se constituir em centros de administração da vida econômica e social. Este surto urbano no território fluminense trouxe mudanças significativas como a valorização do solo e a sua concentração, a expulsão dos posseiros das terras e a transformação de significativa parte deste contingente em agregados das grandes fazendas de café e a criação de vilas ou elevação de pequenos núcleos urbanos a esta categoria. São exemplos ocorridos no período imperial: Valença (1823), Mangaratiba (1831), São Sebastião de Barra Mansa (1832), Vassouras (1833), Paraíba do Sul (1833) e Sant' Anna do Piraí (1837).

Este dinamismo também se refletia no aumento da população urbana na região e o exemplo de Vassouras é bastante ilustrativo: 20.589 habitantes em 1840 (sendo 14.333 escravos) e mais de 35.000 em 1850 (20.158 escravos). E o aumento populacional condicionava uma maior complexidade na vida econômica e social através, por exemplo, da vinda de diferentes artífices, portugueses, imigrantes e mascates para estes novos territórios. Além do mais, estes espaços, sobretudo os núcleos que assumiam papel de liderança nesta nova rede regional, passaram a receber os próprios senhores de terra que, ampliando suas atividades econômicas (eram, sobretudo financistas e banqueiros) e seus horizontes culturais com os modismos modernos e "civilizados" passaram a optar por estabelecerem residência em palacetes citadinos.

Outra dinâmica regional importante no período em tela e já mencionada faz referência à opulência do norte fluminense capitaneada pela cidade de Campos dos Goytacases, significativa área produtora de açúcar e gêneros diversos voltados para o abastecimento interno da Província. Chrysóstomo (2006) discute a produção da rede urbana no na província no contexto de afirmação da política centralizadora do Império, identificando o papel assumido pela antiga cidade no comando político, econômico e social da região. A autora assume o pressuposto de que este núcleo constituiu-se em espaço privilegiado de legitimação do poder estatal e, nesse sentido, a política administrativa do Estado também pode ser entendida como uma política de ordenamento territorial nos espaços urbanos. O texto investigou os aparatos administrativos instalados na cidade e em seus distritos e freguesias voltadas para o controle produtivo, político e social da população. Esta rede de poder, materializada através de uma rede urbana que conectava Campos e sua hinterlândia à capital do Império, subjugando esta região, transformou as relações estabelecidas em seu interior e denotava o recorte regional das políticas territoriais do Império.

Por fim, ressaltamos que tais dinâmicas de base urbano-regionais trazidas pelo texto (o norte fluminense capitaneado por Campos, o "sertão d'oeste", a espacialização das medidas de administração territorial como o instituto das freguesias e comarcas, o retalhamento da província através de grandes propriedades e os caminhos abertos para conexão entre estas, os núcleos urbanos e a capital) envolviam grupos de poder localizados em diferentes espaços da província e impunham uma dinâmica territorial que confirmará a instalação dos semióforos da nação, como aqui apresentados.

Tais dinâmicas foram responsáveis pela instalação de diversos aparatos administrativos de controle político e de veiculação de ideias (tais como escolas, 
cadeias, distritos eleitorais, mercados, sedes policiais, tribunais, hospitais, postos de fiscalização de rendas) que efetivamente asseguraram o controle do território por parte dos "nobres" do império. Controle este exercido a partir do alcance regional (possível através de "fixos" e "fluxos" como ressaltamos oportunamente) dos instrumentos políticos e ideológicos a serviço do projeto aqui engendrado de nação e que se localizavam preferencialmente nos espaços urbanos constituídos para tal finalidade.

Todas estas questões, que ressaltam das análises do "enquadramento espaçotemporal" adotado no texto, evidenciam, a nosso ver, a importância dos conceitos de cidade e de região para o estudo do espaço fluminense no tempo pretérito imperial e confirmam a necessária continuidade de pesquisas geográficas sobre a relação Estado, oligarquias rurais e configuração espacial em tempos outros.

\section{CONSIDERAÇÕES FINAIS}

Dinâmicas territoriais que evocam as escalas geográficas do urbano e do regional foram aqui elencadas e observadas em conjunto para percebermos o processo mais amplo de controle da província fluminense. Mais, tais dinâmicas foram investigados de maneira a considerar as especificidades do estudo sobre o espaço em tempos pretéritos, visto ser o período imperial o recorte temporal da pesquisa apresentada. Assim, buscamos analisar ações "planejadoras" do território e observamos tal questão a partir de um viés que se junte aos esforços por uma geografia histórica do atual estado do Rio de Janeiro.

No caminho indicado para o texto, buscamos contextualizar nossos objetos de pesquisa (materialidades espaciais, ideias e ordens) em um cenário maior do país e as determinações geográficas de sua formação, notadamente o processo explicativo a respeito da nossa formação territorial em meio à nação pretendida.

No caso da província fluminense, observamos a constituição de um poder administrativo como garantia de disseminação dos interesses de determinados grupos que, por sua vez, expressaram tentativas de ordenação do território e da sociedade. Aliado aos outros mecanismos de dinâmica do território trazidos no texto (abertura de caminhos, aparatos de ensino, de fiscalização de receitas, limites jurisdicionais, etc.), o texto ressaltou a subjugação de recortes regionais a determinadas dinâmicas urbanas por natureza.

Reafirmamos que, no território fluminense, os distintos níveis de acessibilidade em diferentes regiões denotavam um embrionário processo de divisão espacial do trabalho que indicava, na escala da província, a existência de um comércio interno e do surgimento de um processo de urbanização, e, em escalas maiores, a confirmação do uso seletivo de espaços articulados à expansão do capitalismo europeu e a confirmação do papel do Brasil como ofertador de matérias-primas na divisão internacional do trabalho que se consubstanciava. Novamente na escala provincial, vimos que a dinâmica urbana e a alocação das infraestruturas administrativas a seu serviço consolidaram o poder político dos agentes econômicos mais importantes relacionados às atividades agrícolas, comerciais e manufatureiras. Foram também determinantes para o fortalecimento estatal na regulação dos fluxos e na ampliação de sua rede administrativa.

O caso da província fluminense nos permite investigar sobre a configuração de uma rede (simples, é verdade) e seus nós e sobre a importância das suas cidades e vilas, seus momentos de apogeu e de declínio, em alguns casos. Tal perspectiva nos permite entender, no pretérito, algumas das causas das configurações seguintes do território analisado, chegando até a nos ajudar a entender, por exemplo, a constante desarticulação estabelecida entre o interior do Estado do Rio de Janeiro e a sua região metropolitana (o que poderia, inclusive, fomentar novas e futuras frentes de pesquisa).

Por ora, marquemos que os conceitos de cidade e de região se imbricam na nossa pesquisa histórica em Geografia e que a ideia de instrumentos técnicos disponíveis a cada momento nos permite elencar materialidades constituídas pelos representantes do poder vigente em suas estratégias de controle territorial. Assim, tal caminho investigativo nos permitiu afirmar o caráter regional que as cidades detinham no contexto da província fluminense e, em última análise, do próprio Estado imperial brasileiro. Discutir cidade naquele momento era discutir região. 


\section{REFERÊNCIAS}

[1] Abreu, Maurício de Almeida. Construindo uma geografia do passado: Rio de Janeiro, cidade portuária, século XVII. GeoUSP, 7, Universidade de São Paulo, 2000.

[2] Abreu, Mauricio de Almeida. Sobre a memória das cidades. In: FRIDMAN, Fania; Haesbaert, Rogério (orgs). Escritos sobre espaço e história. Rio de Janeiro: Garamond, 2014, pp. 2754.

[3] Anderson, Benedict. Nação e consciência nacional. São Paulo: Ática, 1989,

[4] Barman, Roderick. Brasil: a formação de uma nação (1798/1852). Stanford: Stanford University Press, 1988.

[5] Carvalho, José Murilo de. Teatro de sombras: a política imperial. São Paulo, Vértice, 1988.

[6] Castro, Iná Elias de. O problema da escala. In: CASTRO, Iná Elias de et. al. (Orgs). Geografia: conceitos e temas. Rio de Janeiro: Bertrand Brasil, 1995, p. 117-140.

[7] Chauí, Marilena. Brasil: mito fundador e sociedade autoritária. São Paulo, Perseu Abramo, 2000.

[8] CORRÊA, Roberto Lobato. Trajetórias geográficas. Rio de Janeiro: Bertrand Brasil, 2000, pp. 183-196. (Capítulo 9: Região: a tradição geográfica)

[9] Corrêa, Roberto Lobato. Estudos sobre a rede urbana. Rio de Janeiro: Bertrand Brasil, 2006.

[10] Costa, Wanderley Messias da. O Estado e as políticas territoriais no Brasil. São Paulo: Contexto, 2001, 10를.

[11] Chrysostomo, Maria Isabel de Jesus. Idéias em ordenamento, cidades em formação: a produção da rede urbana na província do Rio de Janeiro. Rio de Janeiro: UFRJ, IPPUR, 2006. (Tese de Doutorado em Planejamento Urbano e Regional)

[12] Fridman, Fania. Os donos do Rio em nome do Rei. Uma história fundiária da cidade do Rio de Janeiro. Rio de Janeiro: Jorge Zahar/Garamond, 1999.

[13] Fridman, Fania. Três vilas da província fluminense. Estudos de História (2), 2001.

[14] Fridman, Fania. Planejamento e rede urbana no sertão do oeste fluminense. X Encontro Nacional da ANPUR. Anais... Belo Horizonte: ANPUR/UFMG, 2003.

[15] Fridman, Fania. As cidades e o café. VI Congresso Brasileiro de História Econômica. Anais... Conservatória, 04 a 07 setembro de 2005.

[16] Fridman, Fania; Chrysostomo, Maria Isabel de Jesus. Projetos territoriais para o império brasileiro. O caso da província fluminense. Revista Praia Vermelha (20), jan-jun. 2010.
Graham, Richard. Clientelismo e política no Brasil do século XIX. Rio de Janeiro, Editora da UFRJ, 1997.

[17] Guerra, François-Xavier (2003). A nação moderna: novas legitimidades e velhas identidades, in Jancsó, István (org.) Brasil. Formação do Estado e da Nação. São Paulo; ljuí: Hucitec; EdUnijuí, 2003, pp. 33-60.

[18] Hobsbawm, Eric. Nações e nacionalismo desde 1780. Rio de Janeiro, Paz e Terra, 1990.

[19] Holanda, Sérgio Buarque de. História geral da civilização brasileira. Tomo III. São Paulo: Difel, 1962.

[20] Lencioni, Sandra. Região e Geografia. São Paulo: EdUSP, 1999.

[21] Martins, Maria Fernanda Vieira. A velha arte de governar: um estudo sobre política e elites a partir do Conselho de Estado 1842/1889. Rio de Janeiro: IFCS/UFRJ, 2005. (Tese de Doutorado)

[22] Mattos, Ilmar R. O tempo saquarema. A formação do Estado Imperial. Rio de Janeiro: Access, 1994, $3^{\text {a }}$ ed.

[23] Moraes, Antonio Carlos Robert. Território e História no Brasil. São Paulo: Annablume, 2005.

[24] Moreira, Ruy. A formação espacial brasileira. Contribuição crítica aos fundamentos espaciais da geografia do Brasil. Rio de Janeiro: Consequência, 2014.

[25] Santos, Milton. A natureza do espaço: Técnica e tempo. Razão e Emoção. São Paulo: EdUSP, 2004. 4. ed.

[26] Silva, Marcelo Werner da. A Geografia e o estudo do passado: conceitos, periodizações e articulações espaçotemporais. Terra Brasilis (Nova Série) [Online], 1, posto online em 05/11/2012. <http://terrabrasilis.revues.org/246> 


\section{Capítulo 8}

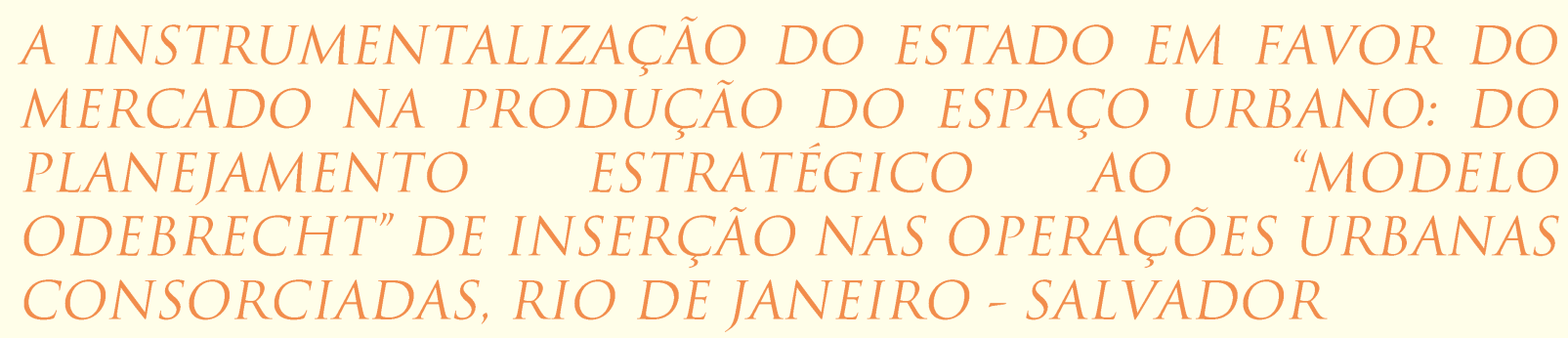

Piero Carapiá Lima Baptista

Resumo: O imbricamento entre o Estado e as empresas privadas é um fato bastante conhecido no Brasil, chegando mesmo às vias do fisiologismo. Entende-se que não se trata mais de um desvio de percurso, derivada da insuficiência de ferramentas anticorrupção; tem em verdade definido o mais recente modelo de produção do espaço urbano brasileiro. Assim, este trabalho propõe apresentar como o Estado adapta-se em favor dos interesses do mercado nesta produção, processo próprio ao capitalismo e que no Brasil estaria tomando forma por meio de um "modelo Odebrecht" de captura, planejamento, prática, gestão e inserção na coisa pública. Este processo será retratado na forma proativa, mas nem sempre explicita, em que a empreiteira se inseriu na recente criação de Operações Urbanas Consorciadas no Rio de Janeiro e em Salvador.

Palavras-chave: produção do espaço urbano no Brasil, modelo Odebrecht, Operações Urbanas Consorciadas

${ }^{*} \mathrm{O}$ trabalho foi apresentado no XV SIMPURB e na revista Brazilian Journal of Development da qual existe autorização para a publicação nesse livro. 


\section{INTRODUÇÃO}

O imbricamento entre a gestão pública e as empresas privadas é um fato bastante conhecido no Brasil, chegando mesmo às vias do fisiologismo. Tanto a perspectiva histórica quanto os recentes escândalos de corrupção envolvendo diversas instâncias públicas e empresas privadas comprovam que a prática já não é mais entendida como um desvio pontual dentro do processo, nem mesmo como um tipo de desvio recorrente, fruto da insuficiência de meios de controle e de ferramentas anticorrupção; tem em verdade definido o mais recente modelo de produção da cidade contemporânea brasileira e destacado o protagonismo de grandes empreiteiras, tal como a Odebrecht. Ao tornar-se cada vez mais naturalizado e cristalizado dentro do modelo de gestão, planejamento, legislação urbanística e prática na produção da cidade, do urbano e do direcionamento dos investimentos, é possível afirmar que nossas cidades têm ganhado novos contornos e paisagens fruto da agudização dessas relações entre o poder público e os grandes interesses privados. É sob esta égide que se pretende indicar neste trabalho indícios de um modelo de inserção proativo na coisa pública, nem sempre explícito, presente na participação da Odebrecht no caso da Operação Urbana Consorciada (OUC) do Porto Maravilha, no Rio de Janeiro, e também no processo que levou a consolidação das poligonais de OUC em Salvador, definidas no Plano Diretor de Desenvolvimento Urbano (PDDU) de 2016. Para entender este contexto, vale considerar também a recente experiência dos megaeventos esportivos ${ }^{31}$, que por favorecerem enormemente algumas empreiteiras, abarcar grandes quantias de dinheiro público e flexibilizar diversos pontos na legislação ajudou - entre financiamentos, frequentes aditivos e o conveniente "caráter de urgência" - a oportunizar e prolongar este modelo de produção da cidade contemporânea orientado pela vontade das empreiteiras e do mercado.

Assim, considerando as transformações e a consolidação da visão gerencial/empresarial na administração pública por meio de reformas no aparelho estatal (FRESNEDA, 1998; PEREIRA, 1998), e mesmo a adoção

\footnotetext{
${ }^{31}$ A saber, o Pan-americano de 2007 no Rio de Janeiro, a Copa do Mundo FIFA Brasil 2014 e os Jogos Olímpicos de 2016 no Rio de Janeiro.
}

dos princípios de governança corporativa (MATIAS-PEREIRA, 2010), atualmente o que se percebe é a extrapolação destes princípios em função de benefícios e ônus assimétricos na sociedade, convertendo o poder público não em um parceiro, mas em um facilitador, promotor e mesmo garantidor de lucros a interesses particulares. Ao mesmo tempo em que as cidades brasileiras padecem de déficits históricos em sua urbanização, distribuição de investimentos e regularização fundiária, motivos que, junto à insatisfação e descrédito na política participativa muito contribuíram para as crescentes crises e disputas urbanas $^{32}$ (MARICATO, 2013; BAPTISTA, 2016), o poder público lança a urbe como território de especulação imobiliária, como atrativo para o mercado financeiro e mesmo como canteiro de obras e programas controversos como o Minha Casa, Minha Vida (MCMV) e o Programa de Aceleração do Crescimento (PAC) ${ }^{33}$ que, a despeito dos investimentos, em razão de obras questionáveis e muitas vezes precárias, em verdade parecem funcionar mais como meios de vazão da capacidade produtiva de empreiteiras (BAPTISTA, 2014). Considerando a concepção de cidade-empresa, cidademercadoria e cidade-pátria (VAINER, 2000), bem como os reflexos práticos de uma "cidade de exceção" (VAINER, 2011), é necessário constantemente investigar a

\footnotetext{
32 Em meio à efervescência dos debates pós "Jornadas de Junho de 2013", Maricato aponta que as razões da crise se encontram na questão urbana brasileira: a) os tradicionais clientelismos políticos que agarram-se na manutenção da pobreza sem jamais retornar ao tema inacabado da reforma urbana; b) na luta do capital privado pela posse das terras formais e terras públicas, levando a expansão da fronteira urbana para a "periferia da periferia"; c) dos capitais que "se assanham na pilhagem dos fundos públicos, deixando elefantes brancos para trás" (MARICATO, 2013) - no que podemos facilmente enquadrar 0 caso dos equipamentos produzidos apenas em função dos megaeventos.

${ }^{33}$ Segundo o governo, o PAC ajudou a dobrar os investimentos públicos brasileiros (de 1,62\% do PIB, em 2006, para $3,27 \%$ do PIB, em 2010) e a ajudar o Brasil a gerar 8,2 milhões de postos de trabalho, que teria ajudado o Brasil a minorar os efeitos da crise financeira mundial de 2008-2009, mantendo a continuidade do consumo de bens e serviços e aliviando os efeitos da crise sobre as empresas nacionais. Dados extraídos do portal do Programa de Aceleração do Crescimento, do Ministério do Planejamento, disponível em: <http://www.pac.gov.br/sobre-o-pac>, acesso em 13 jun. 2014.
} 
evolução dos mecanismos empregados na configuração destes novos contornos, seja por conta de experiências pontuais e excepcionais como na preparação de megaeventos, seja pela apropriação de instrumentos regulares como as OUCs, por exemplo.

Objetivando um encadeamento de ideias que permita chegar à problemática atual, este trabalho propõe demonstrar: 1) preliminarmente, que o espaço segue sendo produzido de acordo com interesses econômicos e de seus agentes, de modo que o alcance do poder regulatório dos planos diretores e instrumentos similares deve ser entendido à luz destas forças; 2) que o planejamento estratégico, as teorias de uma administração pública gerencial e inspirada na expertise empresarial, bem como o fortalecimento da ideia de governança e das parcerias público-privadas (PPPs) surgem na lacuna deixada pela perda de confiança na matriz modernista de urbanização diante das mudanças de paradigmas e dos novos desafios da globalização; 3) que o poder das empreiteiras no Brasil, a exemplo da Odebrecht, remonta relações de fisiologismo presentes desde a ditadura militar e seguem mantendo sua influência por meio de trocas de favores com o poder político; 4) como a Odebrecht interferiu e aparentemente conduziu a definição de poligonais de OUCs, um modelo que se agigantou no caso do Rio de Janeiro e então extrapola fronteiras, replicando um processo muito similar no caso de Salvador. Este trabalho não pretende esgotar o tema, mas propõe-se a contribuir por meio deste raciocínio e dos casos abordados no entendimento de como o setor privado tem instrumentalizado sua influência no Estado para produzir o espaço urbano segundo seus próprios interesses.

\section{A PRODUÇÃO DO ESPAÇO URBANO GUIADA POR INTERESSES ECONÔMICOS}

Não é novidade que a produção do espaço urbano, suas transformações, perfis de desenvolvimento e eixos de crescimento sejam guiados em boa parte segundo interesses de mercado ou do capital; portanto, esta produção urbana segue interesses e usos complexos de diversos atores/agentes, uma espécie de "urbanização capitalista” (TOPALOV, 1979). Também, o próprio fenômeno da urbanização conhecidamente é demarcado por necessidades industriais, de modernização do transporte e até mesmo em função de empresas, como as cidades que surgiram em função de núcleos urbanos construídos por empresas de grande porte (PIQUET, 1998). A relação entre o capitalismo e a produção do espaço é abordada de maneira complexa e rica por David Harvey em $A$ produção capitalista do espaço (2005), valendo-se de análise contundente sobre como o Estado se transforma para atender às demandas capitalistas particulares, apesar do discurso ilusório de fazê-lo segundo interesse geral.

Acerca deste modelamento da urbanização por meio da ação do capital e dos interesses de mercado, em perspectiva histórica é possível identificar pontos específicos às cidades latino-americanas (entre as quais estão incluídas as brasileiras). Apenas para exemplificar, as grandes cidades que temos hoje foram concebidas ou transformadas por interesses do processo de colonização e exploração, seja por alimentarem atividade portuária necessária ao intercâmbio com a Europa, como as cidades brasileiras banhadas pelo Atlântico, ou, no caso das cidades hispano-americanas, edificadas muitas vezes no interior por conta das minas e da exploração de metais preciosos (SANTOS, 2010). Mesmo que a história da colonização e da formação sociológica ajude a entender esta relação que nos é específica, persistente e que evidencia os caminhos do nosso subdesenvolvimento e das nossas questões urbanas particulares, fundamentalmente deve-se dar maior relevância acerca das variáveis econômicas que permeiam processos de dominação e as resistências mais ou menos bem-sucedidas para evitar ou atenuar esta dominação (SANTOS, 2010). Portanto, nossas cidades, "filhas" de interesses econômicos e estratégicos de potências europeias, cuja elite local normalmente precede mesmo a industrialização e conserva-se desde então no poder político e econômico (SANTOS, 2010), continuam apoiadas nas tradicionais (e novas) trocas de favores na construção do espaço urbano. Superar plenamente esta lógica talvez seja inviável dentro do atual modelo capitalista, mas entender como estes processos se dão atualmente e suas distorções em relação ao que deveria ser o interesse público, elemento basilar da função do Estado, consiste em passo importante na crítica e nas proposições alternativas. 
Portanto, diante desta problemática maior, faz-se a ressalva desde já dos limites de instrumentos como o Plano Diretor (e por extensão outras tipificações de planejamento cada vez mais prolíferas, como plano estratégico, plano diretor estratégico e plano sustentável). Ao analisarmos a questão segundo um olhar contemporâneo e em perspectiva histórica, fica claro que o planejamento, ou a tarefa de urbanistas, geógrafos, arquitetos, entre tantos outros profissionais e técnicos, não dão conta isoladamente da produção de uma cidade equilibrada, sobretudo em cidades vulneráveis como Salvador ou Rio de Janeiro, cujas recentes OUCs analisaremos mais adiante neste trabalho.

Aparentemente estamos diante de mais um "urbanismo em fim de linha" (ARANTES, 1998), não mais sobre as decepções em relação às promessas modernistas; agora temos de lidar com um fim de linha pósmoderno, globalizado e cada vez mais sujeito às vicissitudes do mercado financeiro e dos interesses imobiliários, pior, sob a constante sombra da crise econômica e da necessidade de superá-la a qualquer custo. Mesmo assim é comum a confiança um tanto ingênua de que o PDDU sozinho seja resposta para tal. Assim, ainda é válida a fala de Heliodório Sampaio quando afirmou

\section{[...] o conceito do Plano Diretor vem sendo ampliado e repassado para o grande público incluindo-se aí alguns neófitos do planejamento urbano -, como um instrumento de gestão tão poderoso que não reconhece os limites estruturais, ou conjunturais no afã de promover o tal desenvolvimento urbano, agora dito sustentável" (SAMPAIO, 2010, p. 34).}

Como foi visto, a cidade e o urbano são construídos segundo arranjos de interesses e oportunidades criadas; não parte simplesmente do poder estatal ou de legislação específica sua definição concreta. Mais ainda, as experiências recentes comprovam possibilidades de flexibilizações e exceções legais para atender interesses particulares locais, internacionais, políticos e empresariais, como no caso dos megaeventos esportivos (BAPTISTA, 2014), bem como interpretações várias de um mesmo instrumento e sua função social, a exemplo do próprio PDDU e de instrumentos como Transcon (SAMPAIO, 2010) ou as OUCs. Aproximando-se da meta definida pelo Estatuto da Cidade (2001), atualmente quase
90\% dos municípios brasileiros com mais de 20 mil habitantes já possuem um plano diretor (bem como a totalidade dos municípios com mais de 100 mil habitantes) ${ }^{34}$ e ainda assim nossas problemáticas urbanas permanecem em grande parte, sejam elas antigas ou atuais, o que denota a necessidade não de ignorar o instrumento, mas aproveitá-lo, criticá-lo construtivamente, construí-lo de forma participativa e ir além dele.

\section{A REFORMA DO APARELHO ESTATAL E OS FUNDAMENTOS DO PLANEJAMENTO ESTRATÉGICO (E SEUS DERIVADOS)}

Esta nova etapa de imbricamento entre o poder público e o setor privado a que queremos abordar tem raízes na desconfiança acerca da eficiência do Estado frente às mudanças de paradigmas, à globalização e aos limites de certos modelos de gestão, administração e planejamento nas últimas décadas do século $X X$, de modo que é importante revisitar seus fundamentos gerais. Neste "vácuo" propiciado pelo esfacelamento de antigos princípios, o discurso de promoção do Planejamento Estratégico ganha força, garantindo crescimento e certo protagonismo da visão empresarial de gestão urbana.

Internacionalmente, a execução e a gestão
dos planos urbanos nos países
desenvolvidos/ricos centrais predominantemente realizadas pelos Estados até a década de 1970, ou seja, o predomínio do modelo econômico fordista entre as décadas de 1940 e 1970 garantiu o chamado Welfare State, ou Estado do Bem-Estar social. No entanto, com a crise do petróleo na década de 1970 (pondo em "cheque" o estilo de vida nos subúrbios, muito dependente dos carros), as cidades e metrópoles viram o fluxo de verbas nacionais ou federais praticamente cessarem, e por consequência a matriz modernista/funcionalista, levando a um colapso do planejamento urbano estatal (CHESNAIS, 1995; ARANTES; VAINER; MARICATO, 2000). Diante deste quadro, vários países iniciaram programas de reforma do Estado, tais como o National Performance Review, nos EUA (1993) e o Programa de Reforma do Aparelho do Estado (1995), no

\footnotetext{
${ }^{34}$ No Brasil, segundo dados de 2015, já contavam com um plano diretor $89,2 \%$ dos municípios com mais de 20 mil habitantes, sendo que todos os municípios com mais de 100 mil habitantes já haviam sido contemplados (TODOS, 2016).
} 
Brasil (FRESNEDA, 1998), tornando a reforma administrativa tema central após a eleição de Fernando Henrique Cardoso, em 1995 (PEREIRA, 1998) quem, entre outras coisas, contribui para o fortalecimento da concertação público-privada com a Lei das Concessões (1995), importante para os arranjos atuais. Como uma evolução destes princípios, mais recentemente, o Governo Federal criou em 2005 o Programa Nacional de Gestão Pública e Desburocratização (GESPÚBLICA). Entre os princípios da administração pública gerencial, convém destacar a desburocratização como estratégia de eficiência e flexibilização da gestão. Neste sentido, por exemplo, há o incentivo à reorientação dos mecanismos de controle, ou seja, assume-se que o controle a priori, característico da gestão burocrática, representa um entrave à eficiência e à inovação, enquanto que, na medida do possível, deve ser incentivado o controle a posteriori. Entende-se que a busca de resultados é muito mais relevante que o foco no controle da legalidade, no cumprimento dos formalismos e do rigor técnico (como exemplo prático, não é necessário elencar todos os impactos negativos da agudização desta postura na experiência de sediar os recentes megaeventos, bem como na aplicação do Regime Diferenciado de Contratações - RDC ${ }^{35}$, cujo maior receio era de que as exceções se tornassem regra).

Tornou-se necessário buscar atrair capital, especialmente internacional, e garantir uma gestão mais eficiente. O modelo de gestão cada vez mais empresarial e afinado com as lógicas do Mercado contemporâneo, globalizado e neoliberal - bastante ciente nos anos 1990 da redução do aporte de recursos nacionais - despontava como a solução para estes problemas, traduzindo-se em Planejamento Estratégico, empreendedorismo e competitividade urbana. Consultores internacionais, em especial os catalães (em função do controverso sucesso do "modelo Barcelona"36), prestaram seu "savoir faire" à

\footnotetext{
35 Instituído pela Lei no 12.462, de 2011 em pleno contexto dos preparativos dos megaeventos no Brasil, o RDC previa uma série de facilidades a este modelo visando agilidade e algumas "desburocratizações" que em geral contribuíram para onerar o orçamento e dificultar a estimativa de preços reais.

36 Em referência à fórmula do suposto sucesso inquestionável das Olimpíadas de 1992 em Barcelona, como estratégia de promoção urbana internacional.
}

diversas municipalidades, tendo sido identificado na América Latina e no Brasil um terreno fértil para a ventilação destas ideias, amparados na "sensação de crise aguda" (BORJA; CASTELLS, 1996, p. 156), poderoso mecanismo de convencimento aliado à estratégia de governança.

A sensação de crise de fato existia, muito embora por razões diferentes daquelas vivenciadas pelos países desenvolvidos centrais $^{37}$. Nos países ditos "em desenvolvimento", o período corresponde mais às crises resultantes das dívidas externas e dos consequentes planos de ajuste macroeconômicos promovidos pelo Banco Mundial e FMI, o que terminaria por contribuir para a difusão das ideologias do Estado mínimo, da contenção do gasto público e do neoliberalismo mais do que a falência do modelo fordista e do seu Estado do Bem-Estar social propriamente ditos. No Brasil, esse processo de ajuste explica melhor o progressivo abandono de políticas públicas e investimentos por parte do Estado, bem como o movimento de crescente repasse de funções públicas para a iniciativa privada. $\mathrm{Na}$ América do Sul a crise se instalava em várias nações, criando o cenário ideal para a propagação de 'fórmulas' supostamente capazes de induzir as economias a crescerem e fortalecer o papel das cidades.

Ademais, o próprio Modelo Barcelona não é mais a única referência. Para exemplificar, o ex-prefeito de Nova lorque e empresário de sucesso, Michael Bloomberg, através da iniciativa Mayors Challenge ${ }^{38}$ vem apresentando contornos contemporâneos aos mesmos princípios que tornaram o caso catalão referência mundial e, em 2016, direcionou a proposta para a América Latina e - Brasil. De maneira similar, o Programa Juntos pelo Desenvolvimento Sustentável ${ }^{39}$

\footnotetext{
${ }^{37}$ Uma vez que no Brasil, por exemplo, municípios e mesmo os estados permanecem até hoje amplamente dependentes de verbas da União.

38 A iniciativa da Bloomberg Philanthropies foi lançada pela primeira vez em 2013 para premiar os melhores projetos de cidades norte-americanas. No ano seguinte, foi a vez de as concorrentes europeias e, em 2016, as cidades da América Latina com mais de 100.000 habitantes.

39 Os integrantes formam uma espécie de "dream team" do empresariado nacional, tais como Jorge Gerdau, dono da maior siderúrgica do país, Rubens Ometto, dono da Cosan, gigante da produção de açúcar e etanol, e José Roberto Marinho, das Organizações Globo. Vale lembrar
} 
tem a premissa de levar a eficiência do setor privado para a administração pública, com empresários de diversos setores no Brasil atuando como "mentores" no empreendedorismo urbano de cidades como Campinas (SP), Curitiba (PR), Teresina (PI), entre outras. Ou seja, consultores internacionais, lideranças locais carismáticas e alinhadas com o "empreendedorismo urbano" e com o empresariado continuam na moda, reforçando a ideia de que a atuação do Estado e as questões político-ideológicas pertinentes à produção do espaço urbano possam ser reduzidas a soluções técnicas de expertise empresarial.

Ainda sobre o empreendedorismo urbano, é possível perceber este discurso desde as teorias de Administração da década de $1980^{40}$, ou seja, o planejamento estratégico urbano (conhecido pela influência da Harvard Business School) é uma entre tantas outras expressões deste "pensamento único" (ARANTES, VAINER, MARICATO, 2000) voltado ao mercado e firmado em relações estabelecidas entre o Estado e um suposto cidadão-cliente $^{41}$. Controverso, tais princípios no Brasil deram margem, por exemplo, às constantes denúncias de "cartas marcadas" em licitações e o apoio financeiro das grandes empresas às campanhas políticas. Este tipo de relação implica em questões práticas na malha urbana, direcionando políticas públicas cada vez mais difundidas nas grandes cidades e pautada em interesses particulares, especialmente do mercado imobiliário, que se beneficia no planejamento local das "fatias de cidade", em detrimento do enfoque na totalidade dinâmica característico do ideal dos Planos Diretores (SAMPAIO. 2010). As grandes empresas locais e nacionais, em especial ligadas ao mercado financeiro, ao capital imobiliário e à

que em 2009 a Cosan foi incluída na "lista-suja" do trabalho escravo pelo Ministério do Trabalho, tornando questionável os critérios desta iniciativa.

${ }^{40}$ Neste âmbito, um dos livros mais importantes da década de 1980 é Reinventando o Governo: Como - Espirito Empreendedor está Transformando o Setor Público, de Osborne e Gaebler (1992).

${ }^{41} \mathrm{Na}$ gestão pública gerencial o cidadão é tratado como se fosse um cliente, tal como o fazem as empresas do setor privado, ou seja, o cliente tem o direito de participar e sua avaliação é importante na definição dos critérios de qualidade da gestão. Na prática este princípio parece também englobar nessa "clientela" as grandes empresas, estas, no entanto, com muito mais penetrabilidade na gestão pública. construção civil acharam nesta postura um nicho de mercado e uma parceria bastante duradoura.

\section{A ODEBRECHT NO JOGO POLÍTICO: DA DITADURA MILITAR ÀS DOAÇÕES ELEITORAIS - A CONSOLIDAÇÃO DO FISIOLOGISMO DE ESTADO.}

Das recentes experiências com os megaeventos esportivos em casos extremamente desbalanceados de PPPs ${ }^{42}$ aos escândalos de corrupção que por fim levaram grandes empreiteiras à posição de réus da Operação Lava Jato ${ }^{43}$ - metade das arenas da Copa 2014 estão suspeitas de irregularidades (METADE, 2017), como favorecimentos indevidos, bem como o fisiologismo flagrante levou à cadeia funcionários, executivos, empresários como Marcelo Odebrecht e mesmo o ex-governador Sergio Cabral ${ }^{44}$, o Brasil começa a perceber a dimensão de uma máquina que atravessou mandatos e as diversas instâncias de governo. A parceria de grandes empreiteiras como a Odebrecht com o Estado revelava-se extremamente lucrativa à particulares, porém às custas da sociedade. Sobre as empreiteiras, a página da operação Lava Jato explica que as empreiteiras se cartelizaram em um "clube" para substituir uma concorrência real por uma concorrência aparente. Os preços oferecidos à Petrobras (bem como em várias outras licitações) eram calculados e ajustados em reuniões secretas nas quais se definia quem ganharia o contrato e qual seria o preço, inflado em benefício privado e em prejuízo dos cofres da estatal ${ }^{45}$.

\footnotetext{
$42 \mathrm{Na}$ Copa 2014, a conta final divulgada pelo Grupo Executivo da Copa do Mundo FIFA 2014 GECOPA chega a quase $R \$ 26$ bilhões, com apenas $14 \%$ do capital privado (BAPTISTA, 2014).

${ }^{43}$ A operação Lava Jato é a maior investigação de corrupção e lavagem de dinheiro que o Brasil já teve. Inicialmente investigando os escândalos de corrupção envolvendo a maior estatal brasileira, a Petrobras, atualmente a operação chegou a outras frentes criminosas.

${ }^{44}$ Envolvido em um esquema de propinas para fechar contratos públicos com prejuízo estimado ao erário em mais de $\mathrm{R} \$ 220$ milhões. Entre as acusações está em favorecer que a construtora Andrade Gutierrez se associasse à Odebrecht e à Delta, no consórcio que disputaria a reforma do Maracanã, em 2009.

45 Página da Lava Jato, disponível em: <http://lavajato.mpf.mp.br/entenda-o-caso>, acesso: 17 jun. 2016.
} 
No Brasil, um grupo de quatro grandes empresas de caráter familiar (típico ao capital monopolista dos grupos econômicos constituídos no Brasil) detém o domínio da construção civil e a participação em inúmeros outros negócios no país, desde gêneros alimentícios ao ramo petroquímico, passando por seu controle inúmeras operações de concessões. As empresas OAS, Odebrecht, Camargo Correa e Andrade Gutierrez são conhecidas pelo apelido de "as quatro irmãs", e representam o que há de mais arraigado em relação às trocas de favores entre o poder público e as empresas privadas. Outra característica notável destas quatro empresas é a participação delas em doações para campanhas políticas aos mais diversos partidos. Levando em consideração a proeminência destas empreiteiras em meio às obras dos recentes megaeventos, bem como sua inserção em diversas licitações por todo o Brasil, uma pesquisa divulgada em junho de 2014 pela Pública - Agência de Reportagem e Jornalismo Investigativo, apurou que as "quatro irmãs" doaram entre 2002 e 2012 para comitês e campanhas políticas mais de $\mathrm{R} \$ 479$ milhões, tanto em doações diretas às campanhas, quanto aos partidos em anos sem eleição (figura 01).

Figura 01- Doações realizadas pelas "Quatro Irmãs" a partidos políticos do Brasil, entre 2002 e 2012.

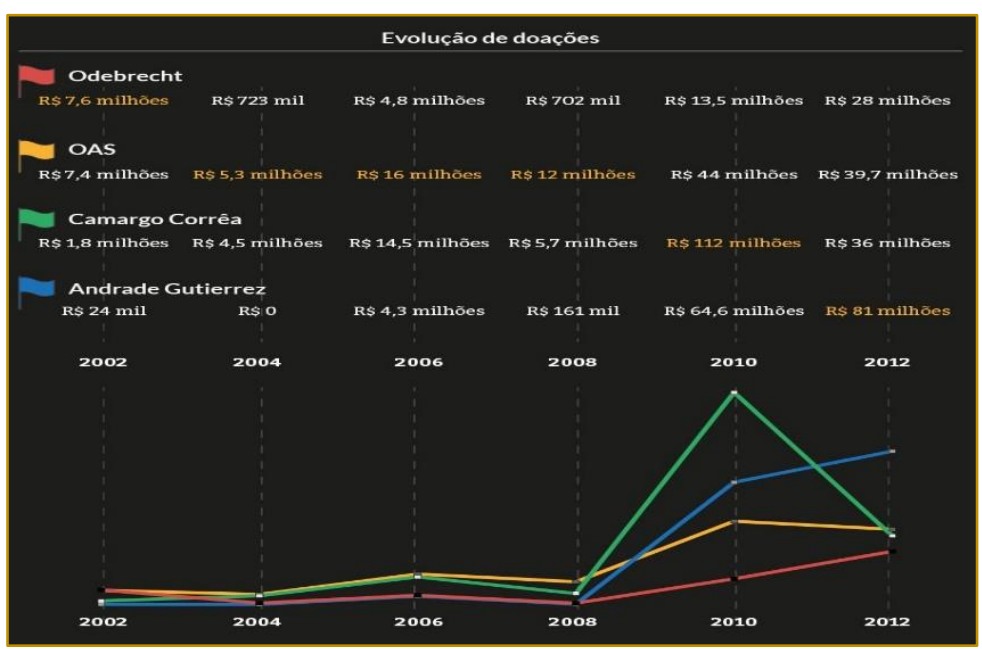

Fonte: As quatro (2014).

Quanto à Odebrecht, uma das "irmãs", responsáveis pelo consórcio OAS/Odebrecht da Arena Fonte Nova, bem como pela reforma do Maracanã, pela PPP e OUC do Porto Maravilha (por meio do Consórcio Porto Novo, junto à OAS e à Carioca Engenharia), entre outras participações, a empresa teria doado no período citado $R \$ 12,1$ milhões ao PSDB, $\mathrm{R} \$ 10,5$ milhões ao PMDB e $\mathrm{R} \$ 10$ milhões ao PT (figura 02). A pesquisa, utilizando a Lei de
Acesso à Informação Pública (Lei № 12.527, de novembro de 2011), destaca ainda que, além dos contratos de obras públicas, estas empresas são beneficiadas pelo poder público através do BNDES, de modo que entre 2004 e 2013 o banco realizou 1665 transferências para as "quatro irmãs", sendo as maiores beneficiadas a Odebrecht e a Andrade Gutierrez. 
Figura 02- Doações do grupo Odebrecht, por partido, entre 2002 e 2012.

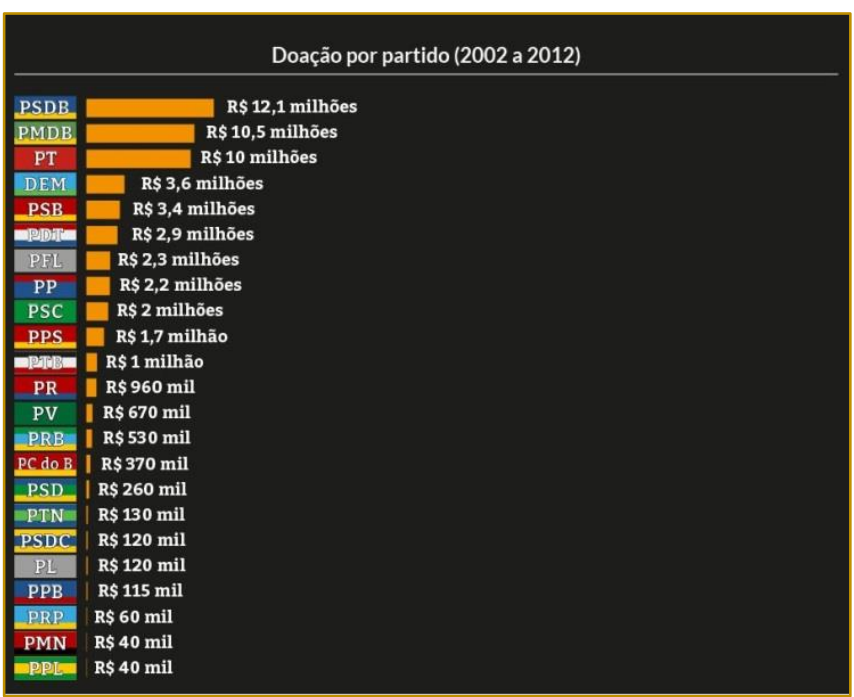

Fonte: As quatro (2014)

Quanto à história da trajetória ascendente da Odebrecht em meio ao jogo político, a empresa, uma das multinacionais mais antigas do Brasil, possui suas origens no ramo da construção civil no Nordeste, rapidamente expandindo seus negócios depois de estreitar relações com a Petrobras, razão pela qual boa parte dos rendimentos da empresa tenham origem no refino de petróleo. Graças às relações firmadas durante 0 governo Geisel, a empresa garantiu uma ascensão meteórica durante o período da ditadura militar brasileira, avançando da 19a posição entre as construtoras nacionais, em 1971, ao terceiro lugar, dois anos depois. Quanto ao financiamento do BNDES, entre 2004 e 2013, a Fundação Odebrecht, a construtora, e a Odebrecht Óleo e Gás receberam juntas mais de $\mathrm{R} \$ 498$ milhões e, além disso, a Braskem recebeu mais de $\mathrm{R} \$ 4,1$ bilhões em empréstimos entre 2008 e 2013. Entre as polêmicas, ao longo dos últimos anos começou a participar do setor de armamentos através da Odebrecht Defesa e Tecnologia, provavelmente não por acaso, pois entre 2007 e 2010 o orçamento do Ministério da Defesa aumentou 45\% (AS QUATRO, 2014). Além de ser a maior ganhadora de licitações para os estádios da Copa e uma das mais favorecidas nas obras das Olimpíadas 2016, a Odebrecht conseguiu o maior contrato de valor global entre os estádios, justamente a Arena Fonte Nova ${ }^{46}$.

\footnotetext{
${ }^{46} \mathrm{O}$ valor das contraprestações anuais (mais de $\mathrm{R} \$$ 107 milhões ao ano, durante 15 anos), somado ao custo da obra de $\mathrm{R} \$ 689$ milhões eleva o custo
}

\section{A PARTICIPAÇÃO DA ODEBRECHT NAS OUCS: UM MODELO QUE SE AGIGANTA NO RIO DE JANEIRO E EXTRAPOLA PARA SALVADOR}

A região portuária do Rio de Janeiro, alvo recente da OUC Porto Maravilha (mapa 01), passou por um discurso de promoção e marketing urbano em conjunto com a expectativa de cativar turistas e lançar uma imagem positiva durante as Olimpíadas de 2016 (ainda que a resposta de valorização imobiliária não tenha sido tão alta quanto esperada, levando o poder público a aumentar sua parcela de contribuição para a operação e manter o interesse do poder privado).

A ideia se encaixa muito bem às práticas de recuperação urbana por meio de OUC, instrumento previsto pelo Estatuto da Cidade (2001) que permite alterar índices urbanísticos, regularizar propriedades, estabelecer novos usos e aumentar o potencial de construção de imóveis de determinado trecho da cidade, no caso a Região Portuária do Rio de Janeiro, área que supostamente atrai a atenção de investidores do setor imobiliário para projetos comerciais e residenciais. Interessados em explorar esse potencial devem comprar Certificados de Potencial Adicional Construtivo (CEPAC), títulos usados para custear operações urbanas que recuperam áreas degradadas nas cidades além de, necessariamente, ter de

global para mais de $\mathrm{R} \$ 2,1$ bilhões (BAPTISTA, 2014). 
investir 3\% na manutenção e recuperação do patrimônio material e imaterial.

MAPA 01- A enorme poligonal (5,5 milhões de $\mathrm{m}^{2}$ ) da Operação Urbana Consorciada que coincide com Área de Especial Interesse Urbanístico (AEIU) da Região Portuária do Rio de Janeiro.

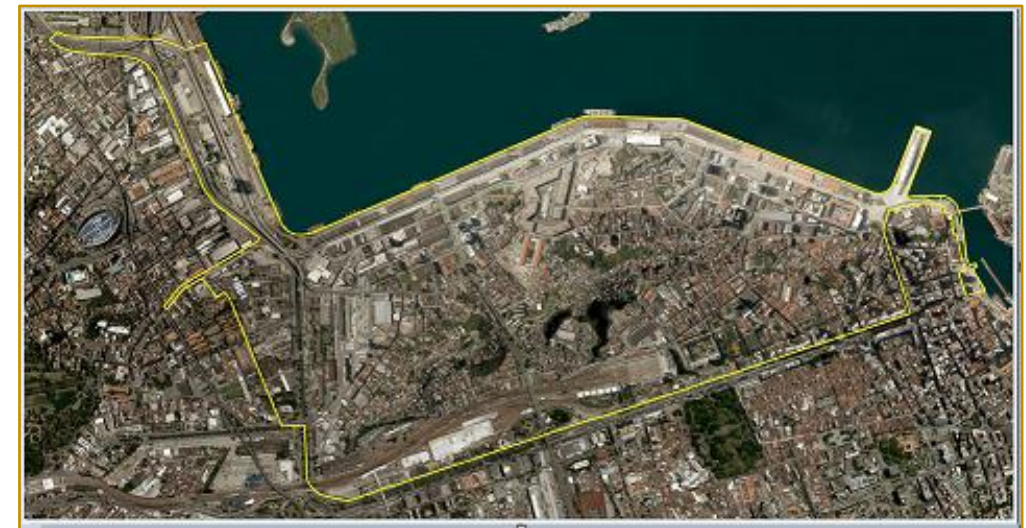

Fonte: site oficial do Porto Maravilha

(Disponível em: <http://portomaravilha.com.br/portomaravilha>, acesso em 17 de junho de 2017.)

$\mathrm{Na}$ prática, isso tem significado intervir em uma área degradada ao viabilizar hotéis, pontos comerciais, equipamentos culturais (o Museu do Amanhã, por exemplo), residências de alto padrão, enfim, uma mudança de perfil cuja origem não se encontra na iniciativa do Estado em identificar o interesse público, mas em um projeto apresentado à prefeitura pela Odebrecht, OAS e a Carioca Engenharia já em 2009 (OLIVEIRA, 2012; GAFFNEY, 2013). Desta forma, de acordo com Oliveira (2012), o Projeto Porto Maravilha foi o primeiro de três leis tramitadas em regime de urgência na Câmara Municipal do Rio de Janeiro, menos de um mês após o anúncio da vitória carioca na competição pela sede das Olimpíadas de 2016. Assim,

Articulado aos decretos de lei 32.575/2010 (RIO DE JANEIRO (Município), 2010d) e 32.666/2010 (RIO DE JANEIRO (Município), 2010e) o Projeto Porto Maravilha estabelece uma Parceria Público-Privada (PPP) inédita no Brasil ao atrelar em um mesmo contrato, a realização de obras, sua manutenção e a privatização de serviços públicos (Oliveira, 2012, p. 240).

A transferência ao poder privado do direito de planejar e gerir a coisa pública (em cerca de 5,5 milhões de $\mathrm{m}^{2}$ ) torna-se evidente, ainda que de forma não declarada:

Embora a autoria do projeto de lei apresentado pelo executivo municipal tenha sido assinada pelo Instituto Pereira Passos
(IPP), a essência do documento apresentado reproduz quase que na íntegra a proposta de planejamento elaborada, no "Relatório Urbanístico da Operação Urbana Consorciada Porto Maravilha", por um consórcio constituído entre as empresas OAS, Odebrecht Engenharia e Construções e Carioca Engenharia [...]. No documento já se encontravam claramente explicitados o desenho estrutural da PPP, as principais diretrizes físico-territoriais e parâmetros urbanísticos do projeto e o modus operandi dos CEPACs, numa apresentação bastante aproximada, se não idêntica, do conteúdo exposto no projeto de Lei (Oliveira, 2012, p. 240).

Única concorrente habilitada para a licitação, o Consórcio Porto Novo (o mesmo que compôs o relatório que "inspirou" a lei) assume o direito de tocar as obras e ações relativas à área, cujo valor inicial era de $\mathrm{R} \$$ 7,5 bilhões (atualmente atualizado em mais de $R \$ 8$ bilhões). Entre as consequências deste empreendimento, há a transferência de recursos públicos por meio de incentivos fiscais, bem como um problema que foi repassado à Caixa Econômica Federal, ao ganhar o leilão de 3,5 bilhões em CEPAC. Assim, o Fundo de Investimento Imobiliário Porto Maravilha (FIIPM, fundo criado pelo FGTS e gerido pela Caixa), ficou com a árdua tarefa de negociar os CEPACs com o mercado imobiliário - e tentar minimamente reaver o investimento. Ainda relativo a este impasse, segundo o Observatório das Metrópoles, 
O modelo implementado pela gestão de Eduardo Paes vinculava a remuneração do Consórcio Porto Novo aos recursos obtidos com a venda de CEPACs em lote único ao FGTS, blindando assim o orçamento municipal. No entanto, nos últimos anos tem ocorrido o processo inverso: a Companhia de Desenvolvimento Urbano da Região do Porto do Rio de Janeiro (Cdurp), gestora da Prefeitura no Porto Maravilha, recomprou mais de 168 mil CEPACs do FGTS, utilizando a verba pública municipal para a obtenção de certificados emitidos pelo próprio município, com vistas a angariar recursos - até então privados - para as intervenções na própria operação urbana (A FALÁCIA, 2017).

O que ficou claro no exemplo do Porto Maravilha é que diante de um mercado retraído e das incertezas de lucro, o Estado extrapola sua função de parceiro, torna-se garantidor e termina assumindo os riscos da operação, um tipo de mecanismo similar ao adotado nos megaeventos, quando os prazos e os compromissos firmados (com a FIFA, o Comitê Olímpico ou a ODEPA) colocavam o poder público em uma posição desfavorável de negociação (BAPTISTA, 2014).

Diante disso, ainda que mais recente e sem tempo hábil para os mesmos tipos de concretizações já evidentes no caso do Porto Maravilha, o caso de Salvador configura um interessante meio de comparação para analisar os caminhos pelos quais esta nova forma de captura, planejamento, execução e gestão do espaço urbano se viabiliza, que aqui podemos chamar de "modelo Odebrecht". Atualmente, sob a égide cada vez mais evidente deste pensamento, é importante, por exemplo, entender a forma como PPPs, suas variantes - PMI (Procedimento de Manifestação de Interesse) e MIP (Manifestação de Interesse da Iniciativa Privada $)^{47}$ - entre outros mecanismos viabilizados por decretos ${ }^{48}$, estão ganhando

${ }^{47}$ Em essência, modalidades de Parceria PúblicoPrivada (PPP). A diferença reside no fato de que para o Procedimento de Manifestação de Interesse (PMI), a iniciativa parte do parceiro público, que convida o mercado (pessoas físicas ou jurídicas) a apresentar propostas de interesse público, enquanto que na Manifestação de Interesse da Iniciativa Privada (MIP), a iniciativa partiria do próprio parceiro privado.

${ }^{48}$ Ocorre que desde a confirmação do Brasil como sede dos mundiais da FIFA e do $\mathrm{COI}$ e, em especial a partir de 2011, o país vem flagrantemente ampliando a atuação desses território no país de maneira crescente e pouco debatida, com reflexos por fim em áreas delicadas das cidades, como os centros tradicionais ou áreas degradadas com potencial de mercado imobiliário (como as regiões portuárias do Porto Maravilha, no Rio de Janeiro, e da Cidade Baixa, em Salvador). A fim de ilustrar, a MIP (particularmente relevante neste trabalho, pois trata-se de uma iniciativa proativa do setor privado em relação ao Município), aprovada em cidades como São Paulo desde 2011, foi utilizada em 2013 nas poligonais de estudo para desenvolvimento de projetos urbanísticos por parte da Odebrecht em Salvador, abarcando a Orla, a Península de Itapagipe e o Centro Antigo de Salvador (CAS, incluindo o Comércio e a Cidade Baixa). Percebe-se aí algo similar - ainda que não "oficialmente" - no funcionamento desta MIP com o movimento proativo por parte das empresas componentes do Consórcio Porto Novo que, como foi visto, deu origem aos decretos e leis que originaram 0 Porto Maravilha; não por acaso, o próprio consórcio ganhou a concorrência (GAFFNEY, 2013).

Portanto, em 2013, enquanto ocorriam os preparativos da Copa 2014, a Prefeitura Municipal de Salvador, articulando-se com a Odebrecht, publicava o Decreto Municipal nํㅡ 23.935, de 17 de maio de $2013^{49}$, este último, atendendo à intenção da empresa Odebrecht, em especial através da Odebrecht Properties $^{50}$, de apresentar à municipalidade a já citada MIP. Tendo prazo inicial de 270 dias para a apresentação dos resultados, o fato é que após as implicações da Odebrecht com a Operação Lava Jato, o estudo encontrou-se "suspenso" para análise da prefeitura desde o começo de 2015. Ainda que atualmente as ações e intenções da

mecanismos, sobretudo na forma de decretos amparados fundamentalmente na legislação que rege as concessões públicas.

${ }^{49}$ A MIP da Odebrecht foi amparada pelo decreto municipal no 23.935, de 17 de julho de 2013, e pela resolução nº 001/2013, publicada em 25 de julho de 2013 no Diário Oficial do Município, mediante a qual o Conselho Gestor de Concessões (CGC) dispõe sobre a referida MIP proposta pela Odebrecht.

50 "Criada em 2012, a Odebrecht Properties é o braço da Organização especializado no mercado de ativos imobiliários. O negócio identifica e concebe projetos, mobiliza capital e realiza investimentos para, posteriormente, assumir a operação de ativos públicos e privados. 
empresa sejam incertas, sobretudo pela instabilidade provocada pela Lava Jato, a coincidência entre as áreas previamente estudadas pela Odebrecht e as poligonais de OUCs (Chamadas de OUC Centro Histórico/Tororó, OUC Ribeira e OUC Orla Atlântica.) apresentadas no novo PDDU de 2016 (figura 04) deixa claro que a empresa foi vital na definição destes espaços - mesmo que este fato não tenha sido externalizado pela Prefeitura em nenhum momento. As três OUCs somam a extensa área de 3.909 hectares (ou seja, 39 milhões de metros quadrados, dimensão muito superior à da OUC do Porto Maravilha), abarcando 45 bairros e 387.964 pessoas (segundo o censo do IBGE de 2010), de modo que, ainda que sob a coordenação do poder municipal, a empresa privada que assumir o planejamento, gestão e definição das prioridades e interesses de investimento em cada uma destas áreas terá para si grande poder sobre a transformação e os rumos do espaço urbano. Assim sendo, enquanto o decreto $n^{\circ}$ 23.935 previa que os estudos da Odebrecht Properties poderiam ser ressarcidos em até $\mathrm{R} \$ 12$ milhões, o mais provável é que a empresa fosse buscar, após acolhimento das propostas, executar as ações das OUCs, tal como fez no Porto Maravilha.

Mapa 02 - As OUC apresentadas no PDDU de Salvador, de 2016. Em destaque a OUC Centro Histórico/Tororó (em amarelo), a OUC Orla Atlântica (em verde) e a OUC Ribeira (em magenta).

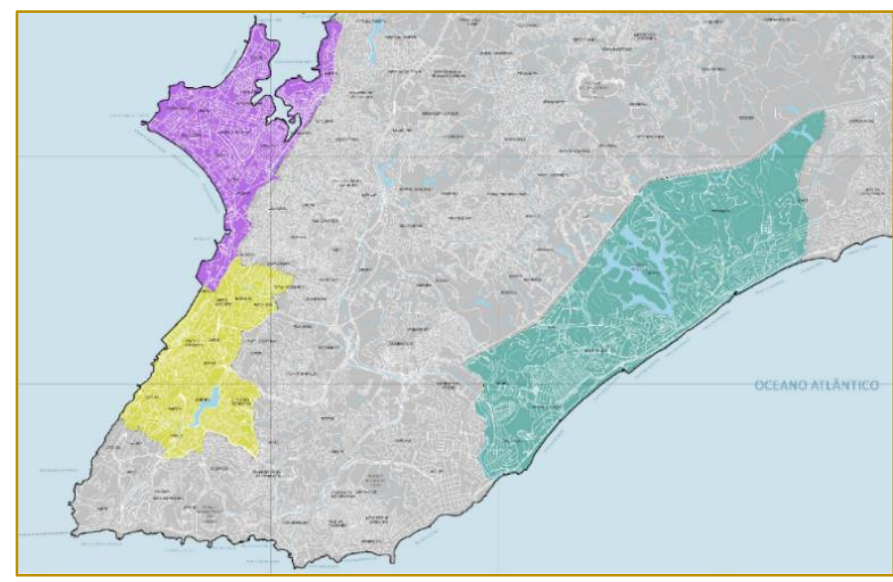

Fonte: PDDU de Salvador 2016.

De forma concomitante, porém não diretamente relacionada nem à Odebrecht nem à OUC (mas ainda assim um instrumento de abertura para o capital imobiliário e financeiro), o Governo do Estado, por meio da Diretoria do Centro Antigo de Salvador (DIRCAS) tenta implementar o Fundo Imobiliário para o Centro Antigo de Salvador (CAS), na poligonal que coincide com a OUC Centro Histórico/Tororó, pondo imóveis públicos como lastro. O fundo (já aprovado pela Caixa) busca viabilizar a operação imobiliária no CAS (cujo discurso é garantir sobrevivência econômica e reabilitação do patrimônio edificado) suprindo 5000 unidades habitacionais preferencialmente com renda acima de 5 salários. A primeira etapa é voltada às classes mais altas em edificações novas, afim de gerar retorno financeiro rapidamente ao empresariado e aos consumidores de potencial econômico mais alto, garantindo sucesso e sobrevida às etapas posteriores (menos interessantes ao mercado), estas últimas sobretudo em edificações pré-existentes, economicamente mais acessíveis e/ou com possibilidade estratégica na proteção do patrimônio material (BAHIA, 2014).

\section{CONSIDERAÇÕES FINAIS}

A linha de raciocínio e os dados apresentados deixam evidente que o interesse de mercado segue como o principal definidor do espaço urbano, de modo que o Estado se adapta e instrumentaliza-se de acordo com estas necessidades e forças. Mesmo que os casos do Rio de Janeiro e de Salvador ainda estejam distantes de seu desfecho, sobretudo pelas grandes dimensões das OUCs, volume de investimento necessários e o cenário atual de crise, retração e desconfiança do mercado que limita o sucesso da venda de CEPACs, é possível perceber uma lógica bastante clara no modus operandi. Ambos foram definidos: a) por propostas e estudos ventiladas ou 
oferecidas de maneira proativa pelo setor privado; b) por conversões de zoneamentos e/ou parâmetros urbanísticos por meio de decretos municipais ou mudanças no PDDU; c) por garantias em dinheiro público (o instrumento de um fundo de investimento fazse presente, mesmo que no caso de Salvador ainda não tenha sido implementado) afim de aumentar o interesse em áreas consideradas normalmente como investimentos arriscados pelo setor privado e; d) com ganhos assimétricos para a sociedade e ordens de prioridades fixadas por interesses do mercado.

É preciso destacar também que este "modelo Odebrecht" de grandes dimensões, cujo formato ainda remete aos "moldes faraônicos" dos recentes megaeventos esportivos, contraria uma outra tendência recente. As mais novas OUCs apresentadas em São

\section{REFERÊNCIAS}

[1] A Falácia do Porto Maravilha: PPPs, CEPACs e o ônus para o poder público. Observatório das Metrópoles, 30 mar. 2017. Disponível em: $<$ http://observatoriodasmetropoles.net/index.php?o ption $=$ com_ k2\&view=item\&id $=1956 \% 3 A a-$ fal\%C3\%A 1 cia-do-porto-maravilha-ppps-cepacs-eo-\%C3\%B4nus-para-o-poder-

p\%C3\%BAblico\&ltemid=180\#>, acesso: 17 jun. 2017.

[2] Arantes, O.; Vainer, C.; Maricato, E. A cidade do pensamento único: desmanchando consensos. Petrópolis, RJ: Vozes, 2000.

[3] Arantes, O. Urbanismo em fim de linha; E outros estudos sobre o colapso da modernização arquitetônica. São Paulo: Edusp, 1998. 224p.

[4] As Quatro irmãs. Pública - Agência de Reportagem e Jornalismo Investigativo, 30 jun. $2014 . \quad$ Disponível em: <http://apublica.org/2014/06/as-quatro-irmas/>, acesso: 17 jun. 2017.

[5] Bahia. Companhia de Desenvolvimento Urbano do Estado da Bahia - CONDER. Diretoria do Centro Antigo de Salvador - Dircas. Centro Antigo de Salvador; Plano de Reabilitação Participativo: Avanços. Salvador: Conder/Dircas, 2014.

[6] Baptista, P. C. L. A Copa do Mundo da FIFA Brasil 2014 em Salvador: os possíveis impactos do megaevento, com ênfase no Centro Antigo de Salvador. Dissertação (Mestrado em Arquitetura e Urbanismo) - Faculdade de Arquitetura, Universidade Federal da Bahia, Salvador, 2014.

[7] Baptista, P. C. L; Huapaya Espinoza, J. C. Beyond the Jornadas de Junho: from the street
Paulo e em Fortaleza, por exemplo, apresentam dimensões mais reduzidas, as vezes circunscritas mesmo a uma gleba (HISSA, ARAUJO, 2017). As razões para tal tendência podem ser estruturadas em dois pontos: 1) os operadores das grandes OUCs em geral se interessam por trechos mais restritos e específicos dentro destas grandes poligonais; 2) as grandes OUCs tendem a impactar os interesses e a vida de uma grande parcela da população, o que naturalmente gera resistências mais contundentes, potencialmente inviabilizando a OUC. Diante destes pontos, da situação crítica da Odebrecht (e de outras empreiteiras nacionais), do momento que perpassa o Rio de Janeiro (em meio à crise econômica) e considerando o processo ainda prematuro no caso de Salvador, paira a dúvida se este "modelo Odebrecht" terá sobrevida de fato.

demonstrations to the voice of the multitude reflections on political exercises in public spaces in the era of networks. Revista Brasileira de Estudos Urbanos e Regionais, v.18-n.2, maio/agosto de 2016

[8] Borja, J; Castells, M. As cidades como atores políticos. Novos Estudos, CEBRAP, no 45, jul. 1996, p. 152-166.

[9] Chesnais, F. A globalização e o curso do capitalismo de fim-de-século. Economia e Sociedade, Campinas, (5): 1-30, dez. 1995.

[10] Fresneda, P. S. V. Transformando organizações públicas: a tecnologia da informação como fator propulsor de mudanças. RSP, ano 49, número 1, 1998, p. 71-92. Disponível em: <http://www.enap.gov.

br/index. php?option=comdocman

\&task=docview\&gid=2890 > . Acesso: 28 abr. 2014

[11] Gaffney, C. Forjando os anéis: a paisagem imobiliária pré-olímpica no Rio de Janeiro. EMetropolis, ano 4, número 15, dezembro 2013, p. 6-20.

[12] Harvey, David. A produção capitalista do espaço. São Paulo: Annablume, 2005

[13] Hissa, M; Araujo, C. Operações Urbanas Consorciadas no Brasil e o caso de Fortaleza. In: XVII Encontro Nacional da Anpur. Anais ... - São Paulo, maio de 2017.

[14] Maricato, E. É a questão urbana, estúpido! In: MARICATO et al. Cidades rebeldes: Passe Livre e as manifestações que tomaram as ruas do Brasil. São Paulo: Boitempo: Carta Maior, 2013, p. 19-26.

[15] Matias-Pereira, J. A governança corporativa aplicada no setor público brasileiro. APGS, Viçosa, v.2, n.1, pp. 109-134, jan./mar. 2010. 
[16] Metade dos estádios da Copa tem suspeitas de irregularidades, segundo delações da Odebrecht. Globo.com, 15 abr. 2017. Disponível em: $\quad<$ http://g1.globo.com/politica/operacao-lavajato/noticia/metade-dos-estadios-da-copa-temsuspeitas-de-irregularidades-segundo-delacoesda-odebrecht.ghtml>, acesso: 16 jun. 2017.

[17] Oliveira, N. G. O Poder dos Jogos e os Jogos de Poder: os interesses em campo na produção de uma cidade para o espetáculo esportivo. Tese (Doutorado em Planejamento Urbano e Regional) -Universidade Federal do Rio de Janeiro, Instituto de Pesquisa e Planejamento Urbano e Regional, 2012.

[18] Osborne, D. \& Gaebler, T. Reinventando o Governo: Como o Espírito Empreendedor está transformando o Setor Público. Brasília, DF: Editora MH Comunicação, 1992

[19] Pereira, L. C. B. Uma reforma gerencial da Administração Pública no Brasil. RSP, ano 49, n. 1, 1998, p. 5-42. Disponível:<https://revista.enap.gov.br/index.php/R SP/article/ view/360>. Acesso: 28 abr. 2014.

[20] Piquet, R. Cidade-empresa: presença na paisagem urbana brasileira. Rio de Janeiro: Jorge Zahar Editor, 1998. 166p.

[21] Salvador, Prefeitura Municipal de. Lei no 9.069 /2016. Dispõe sobre o Plano Diretor de Desenvolvimento Urbano do Município do Salvador - PDDU 2016 e dá outras providências. Salvador:
Prefeitura Municipal de Salvador, 2016. Disponível em: < http://www.sucom.ba.gov.br/wpcontent/uploads/2016/07/LEI-n.-9.069-PDDU2016. pdf>. Acesso: 28 abr. 2017.

[22] Sampaio, A. H. L. 10 necessárias falas: cidade, arquitetura e urbanismo. Salvador: EDUFBA, 2010.

[23] Santos, M. Ensaios sobre a Urbanização Latino-americana. São Paulo: Edusp, 2010. 200p.

[24] Todos os municípios com mais de 100 mil habitantes possuem Plano Diretor. Portal Federativo, 28 abr. 2016. Disponível em: <http://www. portalfederativo.gov.br/noticias/ destaques/todos-os-municipios-com-mais-de-100mil-habitantes-possuem-plano-diretor>. Acesso: 15 jun. 2017

[25] Topalov, C. La urbanización capitalista: algunos elementos para su analisis. México: Edicol, 1979.

[26] Vainer, C. Pátria, empresa e mercadoria: notas sobre a estratégia discursiva do Planejamento Estratégico Urbano. In: ARANTES, O.; VAINER, C.; MARICATO, E. A cidade do pensamento único: desmanchando consensos. Petrópolis, RJ: Vozes, 2000, p. 75-103.

[27] Vainer, C. Cidade de exceção: reflexões a partir do Rio de Janeiro. Apresentação Mesa Redonda "Política Urbana / Planejamento territorial". Anais XIV Enanpur - Rio de Janeiro, maio de 2011. 


\section{Capítulo 9}

\section{A IMPORTÂNCIA DO PORTO SECO PARA A ECONOMIA REGIONAL CONTEMPORÂNEA DO BRASIL: ANÁPOLIS (GO) E PORTO FRANCO (MA) COMO REFERENNCIAS}

\section{João Gabriel da Silva Oliveira}

Antonio José de Araújo Ferreira

Resumo: Os portos secos são recintos alfandegados de uso público, que são importantes para a economia nacional, regional e local uma vez que podem ser indutores de áreas pouco dinâmicas, cuja importância atual pode ser indicada por existirem 63 unidades nas 5 macrorregiões brasileiras, sendo que se utiliza como referências empíricas os portos de Anápolis (GO) e Porto Franco (MA) tendo com objetivo geral analisar e comparar o impacto desses equipamentos. Para tanto, procedeu-se: pesquisa bibliográfica, cartográfica e documental; interpretação visual de documentos cartográficos selecionados; participação em eventos técnico e científicos; análise, seleção, tabulação e interpretação dos dados e informações obtidos. Os resultados revelam que os portos secos de Anápolis e o de Porto Franco concorreram para o incremento econômico desses municípios e da região em que estão inseridos. Conclui-se que ambos tenderão a crescer à medida que se ampliarem as demandas do MATOPIBA e políticas públicas forem efetivadas como indutoras de todo o processo.

Palavras-chave: Porto Seco; Importância; Região. 


\section{INTRODUÇÃO}

Foi com o início da industrialização brasileira que a busca pela competitividade no mercado nacional e internacional começou a ser aguçada. Almejava-se à redução de custos, ao aumento da produtividade, a conquista de novos mercados e a procura por novos fornecedores, de maneira que fossem ampliadas as operações de importações e/ou exportações que inseriram o Brasil definitivamente na lógica global de mercado. Assim, as empresas passaram a necessitar, como nunca, de infraestrutura alfandegária para a realização dos trâmites de suas operações de comércio exterior. Desde a criação do programa "exportar é a solução", em 1965, pelo Conselho Nacional de Comércio Exterior (CONCEX) o Brasil passou a priorizar as atividades de importação e exportação, chegando, em 1981, a fazer parte das 10 maiores economias do mundo Ocidental. Nesse caso, a logística é um dos pontos estratégicos, tanto para a competitividade do país quanto para as empresas, sustentando as atividades no comércio internacional (LOUZADA, 2005).

Visando uma melhor logística $e$, consequentemente, otimizar competitividade e redução de custos no Brasil, iniciaram-se a implantação dos portos secos, que surgem junto a um complexo industrial com o objetivo de incrementar o escoamento de produtos. Os portos secos são, resumidamente, recintos alfandegados que oferecem a possibilidade de obtenção de benefícios fiscais na liberação, armazenagem, manuseio, industrialização e outras atividades afins, todas reguladas pela aduana brasileira (LOUZADA, 2005).

De acordo com o Decreto Federal no 4.765 , de $24 / 06 / 03$, os portos secos são recintos alfandegados de uso público nos quais são executadas operações de movimentação, armazenagem e despacho aduaneiro de mercadorias e de bagagem sob controle aduaneiro. Não podendo ser instalados na zona primária de portos e aeroportos alfandegados, os portos secos poderão ser autorizados a operar com carga de importação e de exportação, ou apenas de exportação, tendo em vista as necessidades e condições locais.

Dessa forma, este artigo pretende responder à seguinte questão: Qual a importância do Porto Seco para a dinâmica da cidade de
Porto Franco - MA e a sua contribuição para o escoamento da produção do MATOPIBA?

Para responder à citada questão de pesquisa, este estudo teve como objetivo geral analisar e comparar os Portos Secos de Porto Franco - MA e o de Anápolis - GO. Como objetivos específicos, buscou-se: a) identificar as mudanças ocorridas nessas cidades após a implantação dos Portos Secos; b) analisar o potencial de expansão do Porto Seco no município de Porto Franco e suas implicações na economia do Maranhão.

Convém ressaltar que, tal artigo é uma ampliação de uma comunicação oral apresentada durante o XV Simpósio Nacional de Geografia Urbana (OLIVEIRA; FERREIRA, 2017) a qual, por sua vez, é vinculada ao Projeto de Pesquisa intitulado "Dinâmica e perspectivas do Itaqui: de 'sonho' a porto de integração regional brasileiro na economia mundial contemporânea". O conteúdo está estruturado da seguinte forma: a metodologia utilizada para elaboração do mesmo; revisão de literatura a respeito do que é o Porto Seco e sobre competitividade no mercado; em seguida, faz-se uma comparação entre as cidades de Anápolis-GO e Porto Franco-MA, mostrando quais mudanças ocorreram nas mesmas após a instalação de seus portos secos; por fim, apresentam-se as considerações finais.

\section{METODOLOGIA}

Compreender determinado tema implica na escolha de técnicas de pesquisa (LAKATOS; MARCONI, 2009). Em se tratando desse artigo que ressalta a importância do porto seco nos municípios de Anápolis-GO e Porto Franco-MA, foram utilizadas as que seguem:

1) Pesquisa bibliográfica, a qual acontece quando um pesquisador utiliza documentos objetivando extrair dele informações, investigando, examinando, usando técnicas apropriadas para seu manuseio e análise; segue etapas e procedimentos; organiza informações a serem categorizadas e posteriormente analisadas; por fim, elabora sínteses analíticas sobre a temática (GIL, 2008);

2) Pesquisa documental (leis, projetos e planos de governo e/ ou da iniciativa particular) e cartográfica (cartas, plantas, mapas), a fim de apreender os fatores que contribuíram para transformações nas 
cidades de Anápolis e Porto Franco a partir da instalação de seus portos secos;

3) Interpretação visual dos documentos cartográficos selecionados;

4) Participação em eventos técnicos e científicos em que a temática portuária foi debatida, a exemplo do Encontro sobre a "Cadeia Produtiva do Estado do Maranhão e sua Integração com o Corredor Centro Norte";

5) Análise, seleção, tabulação e intepretação das informações e dados obtidos conforme as técnicas anteriores.

\section{PORTO SECO}

Primeiramente conhecidos como Estação Aduaneira Interior (EADI), os Portos Secos tiveram início na década de 1970, pelo então Ministro Antônio Delfim Netto, e foram concebidos para serem terminais alfandegados de uso público, localizando-se em zonas secundárias, com o objetivo de aliviar o fluxo de mercadorias existente nas zonas primárias. Antes deles, existiam apenas os Terminais Retroportuários Alfandegados (TRA), os quais eram cognominados de portos secos com calado e tinham a finalidade de superar o afogamento dos portos perante a maré de importações (LOUZADA, 2005).

De acordo com o Regulamento Aduaneiro Brasileiro, que determina as regras específicas para a administração, fiscalização, controle e tributação das atividades aduaneiras quanto às operações de comércio exterior, os portos secos são recintos alfandegados de uso público nos quais são executadas operações de movimentação, armazenagem e despacho aduaneiro de mercadorias e de bagagem sob controle aduaneiro (BRASIL, 2003, artigo 11).

Convém sobressair, que recintos alfandegários são entendidos como aqueles:

[...] localizados em determinadas regiões dentro do país, mas que, para efeitos de alfândega, são considerados como "fora do país". São áreas fisicamente segregadas e seladas onde sua operação é aprovada via especificação do governo federal. São espaços físicos sob controle alfandegário. Existem recintos alfandegados tanto nas zonas primárias quanto nas zonas secundárias. (LOUZADA, 2005, p. 27).
Entre os objetivos dos recintos alfandegários, além de aliviar o fluxo de mercadorias existente na zona primária, destaca-se o de encorajar o comércio internacional através da flexibilização das regras de importação e exportação. A utilização de recinto alfandegado por uma empresa permite que a mesma faça importação de mercadoria e deixe-a armazenada lá, por um determinado período de tempo, com suspensão temporária de tributos. Segundo Louzada (2005), um exemplo para a utilização de recintos alfandegados nas zonas secundárias é o descongestionamento de portos e aeroportos, pois estes seriam, em termos de concepção da sua utilização, lugares apenas de passagem das mercadorias. Assim, a instituição e operação de recintos alfandegados representará a criação de novos postos de trabalho.

Os Portos Secos devem dispor de boa infraestrutura para atraírem as empresas que trabalham com importação e exportação, oferecendo diversos tipos de serviços:

[...] como o de desembaraço aduaneiro; desova; serviços comuns como a estadia de veículos e unidades de carga, pesagem, limpeza; consolidação e desconsolidação documental; serviços exclusivos como a etiquetagem e marcação de produtos, testes de funcionamento, acondicionamento e reacondicionamento e montagem e beneficiamento do bem; entrepostagem; movimentação de contêineres e de mercadorias em geral; manutenção ou reparo de aeronaves ou embarcações; entre outros. (LOUZADA, 2005, p. 36-37).

Portanto, os Portos Secos assumem papel de operadores logísticos na cadeia de suprimentos, assemelhando-se a uma empresa prestadora de serviços de logística, haja vista que é responsável pelo controle de estoques, armazenagem e gestão de transportes que inter-relaciona um conjunto de organizações, criando valor na forma de produtos e serviços, desde os fornecedores de matéria prima até o consumidor final (ABML, 1999). Isso implica que os portos secos são importantes para qualquer país que quer se desenvolver e dispor de alternativas para tal, conforme ressaltado por Araújo (2011). Tal fato é corroborado por FIESP (2018) que revela que no Brasil existem 63 portos secos nas 5 macrorregiões, sendo que 35 unidades localizam-se em 14 estados, uma está no Distrito Federal e 27 ficam em São Paulo. 


\section{COMPETITIVIDADE}

Na contemporânea economia globalizada, a busca por meios que levem as empresas a conseguirem vantagens que aumentem sua competitividade é considerada um desafio dinâmico e imprescindível para seu sucesso. A vantagem competitiva é a base que sustenta qualquer empreendimento. Porter (1989) define vantagem competitiva como a busca de uma posição favorável que visa estabelecer uma condição lucrativa $e$ sustentável contra forças que determinam a concorrência.

A competitividade é essencial para a inserção e manutenção da empresa dentro do mercado; seguindo a lógica capitalista, quanto mais a empresa for competitiva maiores serão as chances de sucesso e, consequentemente, maiores os lucros a serem auferidos. A competitividade deve ser pautada sobre uma otimização de recursos e processos. A administração de operações visa estabelecer estratégias e gerenciar melhor os seus recursos e processos, podendo até mesmo diminuir os seus custos para produzir e entregar bens e serviços e, ao mesmo tempo, almeja atender as necessidades de qualidade, tempo e custo para seus clientes. Essas estratégias devem definir as tecnologias, recursos humanos, organização, capacidade, interfaces e infraestrutura da empresa (SLACK; LEWIS, 2002).

Assim, as empresas buscam locais em que possam se instalar e que ofereçam boa infraestrutura, como, rodovias e ferrovias que favoreçam o escoamento de suas produções, assim como incentivos fiscais por parte dos governos estaduais e municipais. Isso por que, de acordo com FIESP (2018), no porto seco as empresas recebem cargas diversas e preparam para exportação; também recebem mercadorias em importação ainda consolidadas, destinadas a despacho para consumo imediato ou a entroposto aduaneiro. Em se tratando das importações, as empresas podem armazenar a mercadoria pelo período solicitado pelo importador (que pode variar de 1 até 3 anos) em regime de suspensão de impostos, podendo fazer a nacionalização fracionada. Dessa forma, as principais vantagens para as empresas são a possibilidade de prestar os serviços aduaneiros próximos ao domicílio dos agentes econômicos partícipes e realizar procedimentos simplificados para o contribuinte.

O Porto Seco também serve como atrativo para as empresas, almejando ao desembaraço aduaneiro, e consequentemente, otimizando os custos e aumentando a competitividade no mercado nacional e internacional. Por essa razão, as unidades da Federação do Brasil tem envidado esforços no sentido de criar esse tipo de equipamento que já totalizam 63 e se encontram nas 5 macrorregiões, a exemplo dos portos secos de Manaus (AM), Uberaba (MG), Ipojuca (PE), Uruguaiana (RS), Distrito Federal e 27 unidades no estado de São Paulo, sendo que se destacarão os de Anápolis (GO) e o de Porto Franco (MA).

\section{ANÁPOLIS}

Localizada no estado de Goiás, na região central do país, distando 54 km de Goiânia, sua capital, e a $154 \mathrm{~km}$ de Brasília, essa cidade compõe o eixo Goiânia-AnápolisBrasília. Anápolis, além de estar localizada entre duas capitais, é cortada por: rodovias federais, isto é, a BR 060 que vai do Distrito Federal até a fronteira com o Paraguai, em Mato Grosso do Sul, enquanto a BR 153 (Belém-Brasília) interliga Aceguá (Rio Grande do Sul), na fronteira com o Uruguai, à Marabá (Pará); pela rodovia estadual GO 330 (Mapa 1); além de possuir um ramal da Ferrovia Centro Atlântica, a qual liga a mesma ao Porto de Santos e é o marco zero da Ferrovia Norte Sul, que demanda na direção do Tocantins, Maranhão em que se conecta à Estrada de Ferro Carajás e segue para o estado do Pará. 
Mapa 1. Localização da cidade de Anápolis e do DAIA

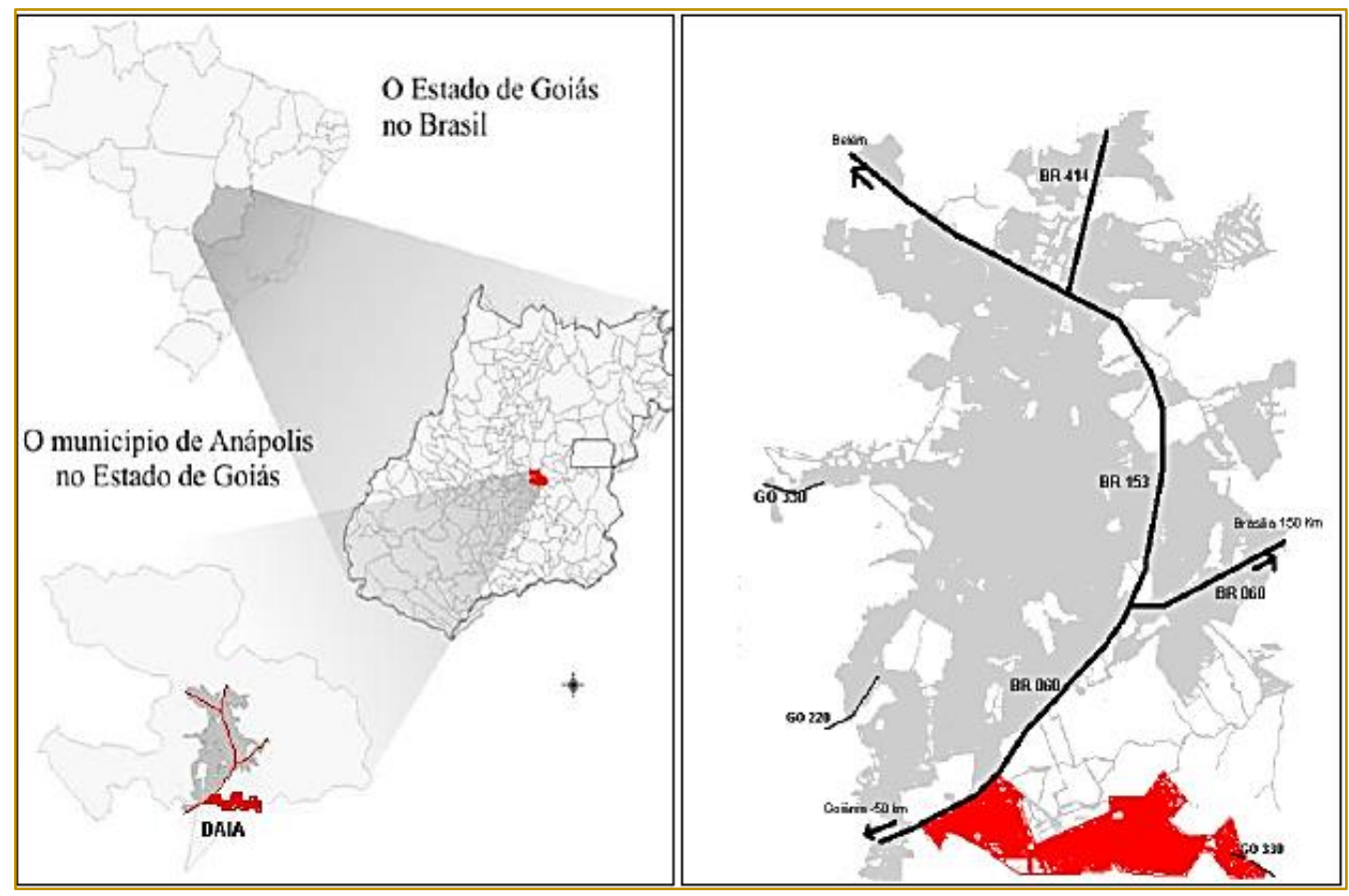

Fonte: FREITAS, 2004

O município de Anápolis possuía, segundo estimativa do IBGE em 2018, 381.970 habitantes e uma extensão territorial de 933,156 km²; em 2014, seu Produto Interno Bruto era de mais de $\mathrm{R} \$ 12,5$ bilhões, que correspondiam a $7,2 \%$ do PIB do estado de Goiás, ficando atrás apenas de Goiânia que concentrava pouco mais de $27 \%$ do PIB estadual, enquanto o PIB per capita era de $\mathrm{R} \$ 35.127,00$ (IBGE, 2016).

O citado município, portanto, tem contribuído para a crescente economia goiana, principalmente a partir dos anos $1970 \mathrm{com}$ a implantação do Distrito Agroindustrial de Anápolis (DAIA). Este é resultado de políticas nacionais de desenvolvimento durante 0 período do regime militar (1964-1985), reestruturando o espaço urbano e levando ao fim boa parte das indústrias localizadas próximas à vila fabril (BERNARDES, 2011). Embora o DAIA tenha oferecido melhores condições para que novas empresas se instalassem em Anápolis, esse não foi o único fator que atraiu as novas indústrias. A partir dos anos 1980, com uma crise fiscal instalada no Brasil, a política de desenvolvimento industrial, que antes era feita pelo governo federal, passou a ser elaborada pelos estados (PASCHOAL, 2012). Dessa forma, efetivou-se o programa Fundo de Participação e Fomento à Industrialização do Estado de Goiás (FOMENTAR), em 1984, como política de incentivos fiscais, para atrair indústrias para o território goiano. Assim, impulsionou-se a instalação de empresas nesse estado, através da concessão de crédito de ICMS. Com isso, devido à sua localização estratégica, que facilitaria o escoamento dos produtos, a cidade de Anápolis foi escolhida por algumas empresas visando à implantação de indústrias de diferentes ramos. Logo, a partir de 1990 a política industrial goiana obteve melhores resultados, revelando um relativo sucesso do mencionado programa e o crescimento do DAIA.

Sobre os fatores que contribuíram para a ampliação e o desenvolvimento do referido DAIA, sobressaem-se:

[...] os incentivos fiscais fornecidos através dos fundos de fomento estadual, como o Fundo de Participação e Fomento à Industrialização do Estado de Goiás (FOMENTAR), instituido pela Lei Estadual no. 9.489 de 19 de julho de 1984, depois, pelo Programa de Desenvolvimento Industrial do Estado de Goiás (PRODUZIR), Lei Estadual no. 13.591 de 18 de janeiro de 2000; dos recursos disponibilizados pelo governo federal através do Fundo Constitucional para o Centro-Oeste (FCO), regulamentado pela Lei Federal no 7.827 de 27 de setembro de 1989; além da inserção por tempo variável 
dos tributos municipais. (DIAS, 2011, p. 7677).

Visando ao fortalecimento do setor industrial de Anápolis, foi instalado na década de 1990 - Porto Seco Centro-Oeste - Estação Aduaneira de Interior - (EADI), importante infraestrutura logística. Surgiu, em 2000, o programa PRODUZIR, sucessor do FOMENTAR, almejando melhores incentivos para a instalação de novas empresas. Durante essa década e no início da segunda do século XXI, desenvolveu-se o projeto e a construção da Plataforma Logística Multimodal de Goiás (PLMG), com a intenção de ser mais um atrativo e uma relevante infraestrutura para o escoamento de cargas produzidas nesse estado, articulando-se também ao Porto Seco (RODRIGUES, 2004).

Assim, se nos primeiros anos de funcionamento, final da década de 1970 e inicio de 1980, o DAIA contava apenas com 14 empresas, em 2008 o mesmo possuía 110 unidades ativas, implicando em um acréscimo de mais de 785\% (DIAS, 2011). Tais empresas distribuiem-se em segmentos como indústrias químicas e farmacêuticas, de fertilizante e de adubo, de gêneros alimentícios e laticínios, do setor metalúrgico, além de empresas especializadas em distribuição e logística, entre outras.

Ao analisar o Produto Interno Bruto do eixo Goiânia-Anápolis-Brasília, entre os anos de 1970 e 2014, percebe-se, em Brasília e em
Goiânia, que o PIB cresceu continuamente. Porém, quando se trata da cidade de Anápolis, foco da comparação com o município maranhense de Porto Franco, o PIB entre os anos de 1970 e 1980 registra incremento de $190 \%$, passando de $\mathrm{R} \$ 737$ milhões, em 1970, para $R \$ 2,1$ bilhões, em 1980; já no período entre 1980 e 1985 a ampliação do PIB foi de apenas 10\%. Em relação ao período entre 1985 e 1996 há um decréscimo do valor do PIB de aproximadamente $18 \%$, passando de $R \$ 2,3$ bilhões em 1985 para $R$ \$ 1,9 bilhão em 1996 (Tabela 1). Assim, nota-se que ao instituir o programa FOMENTAR, em 1984, o governo de Goiás já previa uma queda do valor do $\mathrm{PIB}$, que só voltou a crescer no final da década de 1990 e início de 2000, quando chegou a $R \$ 3,5$ bilhões, o correspondente a $79 \%$ a mais que 1996. A partir dos anos 2000, com a instalação do Porto Seco Centro-Oeste e com o novo programa de incentivo fiscal, o PRODUZIR (substituto do FOMENTAR), o PIB de Anápolis registrou incremento de forma contínua e isso decorreu da instalação do Distrito Agroindustrial de Anápolis; assim, de 2000 a 2010 o PIB ampliou aproximadamente $150 \%$, passando de $\mathrm{R} \$ 3,5$ bilhões em 2000 para $\mathrm{R} \$ 8,9$ bilhões em 2010. E, mais recentemente, em 2014, o PIB municipal de Anápolis alcançou $\mathrm{R} \$ 12,7$ bilhões, o que representa 40\% em relação a 2010.

Tabela 1. Produto Interno Bruno no eixo Goiânia-Anápolis-Brasília, em R\$ (1.000)

\begin{tabular}{|c|c|c|c|c|c|c|c|}
\hline $\begin{array}{c}\text { Cidade/ } \\
\text { Ano }\end{array}$ & 1970 & 1980 & 1985 & 1996 & 2000 & 2010 & 2014 \\
\hline Brasília & $\begin{array}{c}7.832 .40 \\
5\end{array}$ & 30.647 .509 & 37.453 .325 & 57.377 .314 & 92.949 .871 & $\begin{array}{c}133.776 .12 \\
1\end{array}$ & $\begin{array}{c}194.432 .00 \\
0\end{array}$ \\
\hline Anápolis & 737.822 & 2.144 .188 & 2.375 .820 & 1.953 .120 & 3.502 .108 & 8.977 .130 & 12.714 .454 \\
\hline Goiânia & $\begin{array}{c}2.534 .29 \\
4\end{array}$ & 8.496 .905 & 10.294 .133 & 16.289 .220 & 15.868 .529 & 21.815 .337 & 46.094 .735 \\
\hline
\end{tabular}

Fonte: Ipeadata/lbge 
Na Tabela 2 observa-se a importância dos programas de incentivos fiscais do estado de Goiás para a geração de empregos. Dentre os vários programas de incentivos fiscais, dois são principais, ou seja, o PRODUZIR e o FOMENTAR. Juntos, esses programas de incentivos fiscais geraram, até 2012, mais de 108 mil empregos diretos no território goiano; desse total, $62,6 \%$ dos empregados recebiam menos de dois salários mínimos e a média salarial era de $R \$ 1.415,57$. Verifica-se, também, que o número de empregados com nível superior é de apenas $7,7 \%$, o que mostra uma baixa qualificação profissional dos trabalhadores, interferindo diretamente na média salarial citada anteriormente.

Tabela 2. Número de empregos por programa e média salarial em Goiás, 2012

\begin{tabular}{|c|c|c|c|c|c|}
\hline \multirow{2}{*}{$\begin{array}{c}\text { Programa } \\
\text { Empregos } \\
\text { Diretos }\end{array}$} & Mulheres & $\begin{array}{c}\text { Curso } \\
\text { Superior }\end{array}$ & $\begin{array}{c}\text { Menos de 2 } \\
\text { salários } \\
\text { mínimos }\end{array}$ & $\begin{array}{c}\text { Média Salarial } \\
(\mathrm{R} \$)\end{array}$ \\
\hline Fomentar & 49.357 & 11.533 & 4.301 & 30.421 & $1.465,03$ \\
\hline Produzir & 56.064 & 12.997 & 3.916 & 35.660 & $1.351,66$ \\
\hline Total Geral & 108.544 & 24.947 & 8.457 & 67.958 & $1.415,57$ \\
\hline \multicolumn{5}{|c|}{ Fonte: SIC / Censo Produzir 2012 } \\
\hline
\end{tabular}

\section{PORTO FRANCO ENQUANTO MUNICÍPIO}

A cidade de Porto Franco remonta a 02/04/1919 e está localizada no Sudoeste do estado do Maranhão; pertence à Mesorregião Sul Maranhense e à Microrregião de Porto Franco (Mapa 2). O município homônimo possui área de $1.417 \mathrm{~km}^{2}$, com uma população de aproximadamente 21.506 habitantes e uma densidade demográfica de 15,17 habitantes/km² (IBGE, 2010). Limita-se: ao Norte - com os municípios de Campestre do Maranhão e Lajeado Novo; ao Sul - com os municípios de Estreito e São João do Paraíso; a Leste - com o Município de São João do Paraíso; e a Oeste - tem como limite o rio Tocantins.

A sede de Porto Franco fica a $718 \mathrm{~km}$ de São Luís, capital do estado, e a $100 \mathrm{~km}$ de Imperatriz, que é a segunda maior cidade maranhense. Porto Franco possuía, segundo estimativa do IBGE (2018), 23.675 habitantes e seu PIB, em 2014, chegou a $R \$ 439$ milhões o que corresponde a apenas $0,57 \%$ do PIB do
Maranhão, ocupando a 23a posição no ranking dos 217 municípios desse estado.

Porto Franco está localizado numa região estratégica, pois faz parte da bacia do Rio Tocantins, é cortado por duas rodovias federais (BR 010 e BR 226) e uma estadual (MA 335); ainda passa por esse município a Ferrovia Norte-Sul, indo até a cidade de Açailândia em que alcança a Estrada de Ferro Carajás que vai para o Porto do Itaqui, em São Luís. Tal situação geográfica tem favorecido a implantação, em seus arredores, de vários empreendimentos como: Hidrelétrica de Estreito; Suzano Papel e Celulose; e o Distrito Industrial. Este comporta - Pátio de Integração Multimodal da Companhia Vale, localizado a $19 \mathrm{~km}$ do centro da sede de Porto Franco, no sentido de Estreito (OLIVEIRA; FERREIRA, 2017). O mesmo abriga empresas como: Ceval, Cargill, Multigrain, Ceagro e Algar Agro, que recebem grãos, em sua grande maioria de soja, para carga, transbordo, armazenagem e produção de óleo vegetal (BELFORT; SILVA; OLIVEIRA, 2012). 
Mapa 2. Localização de Porto Franco no Maranhão

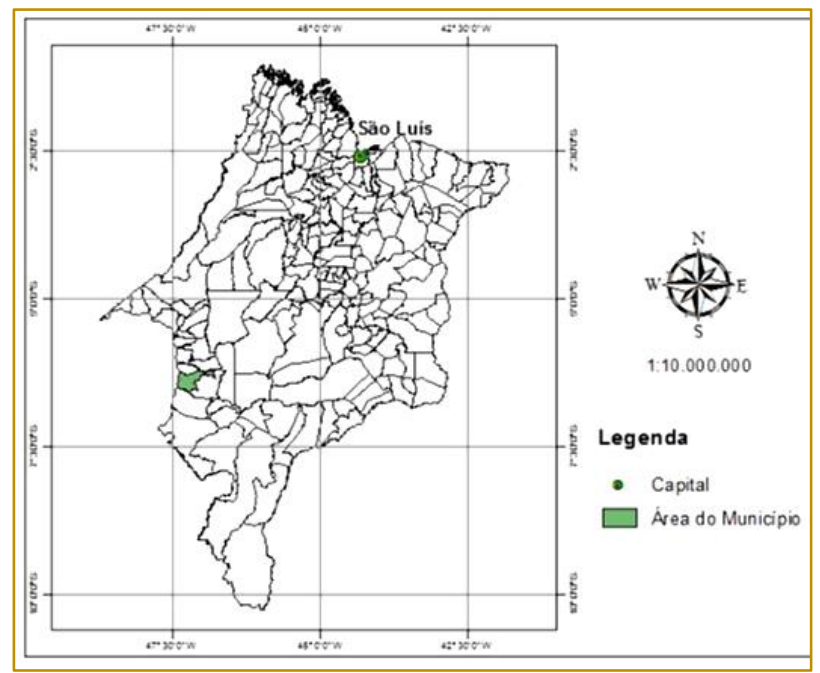

Fonte: Correia FILHO, 2011

Aproveitando-se da sua situação estratégica, através do acesso aos diversos modais de transporte (FERREIRA, 2009), o Distrito Agroindustrial de Porto Franco, criado em 12/05/2005, veio fortalecer a vocação desse município para o agronegócio a partir da indução de "médios e grandes produtores de soja" (DIAS FILHO, 2013, p. 131). Com efeito, em julho de 2005 foi iniciada a construção da primeira fábrica de esmagamento de soja do Maranhão-ABC/INCO (Algar Agro), que começou a operar em 2007, contribuindo para que o município em tela se consolidasse como polo indutor do desenvolvimento regional, podendo assim, agregar valor à soja e gerar renda visto que houve necessidade de maior contratação de mão de obra, contribuindo para a melhoria de seus indicadores sociais e econômicos e do estado do Maranhão (OLIVEIRA; FERREIRA, 2017).

Esse empreendimento trouxe mudanças significativas no modo de vida da população e em toda a economia local e regional. Isso porque:

\section{O impacto desta ação em todos os setores da economia local foi visível, significativo e marcante, como: a abertura de novas empresas, houve, um enorme incremento para os pecuaristas da região, que antes tinham uma produção sazonal, que caia drasticamente durante o período de seca e hoje tem acesso à compra dos subprodutos da soja (BELFORT; SILVA; OLIVEIRA, 2012, p. 7).}

De acordo com a Revista Isto é Dinheiro, na edição de janeiro de 2008, a implantação do
Distrito Agroindustrial e a operação da primeira usina esmagadora de soja do Maranhão consolidaram a posição de Porto Franco como polo de atração de investimentos e negócios da região, que é considerada a nova fronteira agrícola do país (ISTO É DINHEIRO, 2010 [online]).

Outro fator que favorece a atração de investimentos para a cidade de Porto Franco é sua localização central na nova fronteira agrícola do país, composta pelos estados do Maranhão, Tocantins, Piauí e Bahia, constituindo o chamado MATOPIBA ${ }^{51}$ (Mapa 3).

\footnotetext{
51 "A expressão MATOPIBA é um acrônimo criado com as iniciais dos estados do Maranhão, Tocantins, Piauí e Bahia. Ela corresponde aos limites de 31 microrregiões geográficas do IBGE, reúne 337 municípios e representa um total de cerca de 73 milhões de hectares. O território do MATOPIBA é complexo. Ele engloba 324.326 estabelecimentos agrícolas (33.929.100 ha). Ocorrem na área 46 unidades de conservação (8.334.679 ha), 35 terras indígenas (4.157.189 ha) e 781 assentamentos de reforma agrária e áreas quilombolas (3.033.085 ha) num total de 13.967.920 ha de territórios legalmente atribuídos (19,1\% da região)" (MIRANDA; MAGALHÃES; CARVALHO, 2014, p.2). No Maranhão, o MATOPIBA abrange 15 microrregiões e 135 municípios em 22.982.346 hectares (33\% dessa "nova fronteira agrícola"), sendo que na safra 2014/2015 essa unidade da Federação se destacou na produção de milho (1ํ lugar), arroz e algodão em plumas ( $2^{\circ}$ maior produtor), além de soja (3ำ lugar). Cf. MARANHÃO tem..., 2015 apud FERREIRA, 2017.
} 
Com efeito, ao analisar o PIB nos anos 2000 e 2013, constata-se que "houve crescimento de $542 \%$ no PIB do Matopiba, com destaque para algumas microrregiões, como [...] Porto Franco (Maranhão), com 832\%, saindo de R\$
177 milhões para $\mathrm{R} \$ 1$ 1,66 bilhão" (PEREIRA; PORCIONATO; CASTRO, 2018, p. 49), o que estava acima da média desse espaço geográfico.

Mapa 3. Localização do MATOPIBA

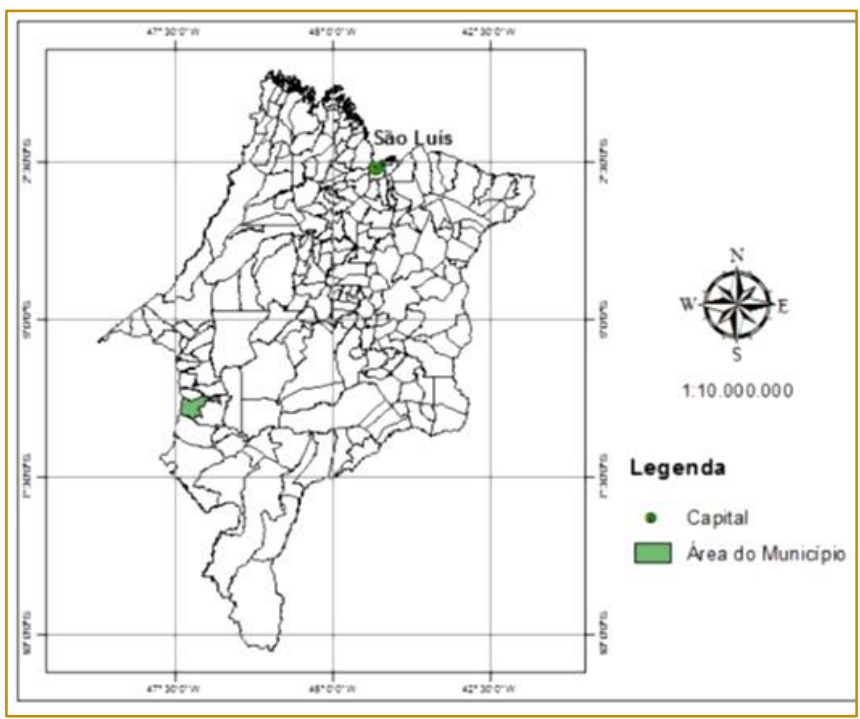

Fonte: Embrapa/Gite, 2014

\section{O PORTO SECO EM PORTO FRANCO - MA}

A cidade de Porto Franco se localiza no meio do caminho entre o MATOPIBA e o Porto do Itaqui, em São Luís, que é o porto brasileiro mais próximo do Hemisfério Norte. Cidade privilegiada, por ser cortada pelas BRs 010 e 226 e pela ferrovia Norte-Sul, que, via Estrada de Ferro Carajás, a interliga ao citado equipamento portuário organizado (OLIVEIRA; FERREIRA, 2017).

Tendo em vista que o principal produto de exportação do MATOPIBA é a soja, tem-se que Porto Franco é um importante corredor para o escoamento dessa cultura para o mercado internacional via Porto do Itaqui. Assim, pela localização e pelas perspectivas, a região de Porto Franco passou a atrair empresas nos últimos anos, a exemplo do grupo Algar Agro $^{52}$, o qual em 2007 investiu:

52 O Grupo Algar é sediado em Uberlândia, Minas Gerais, e tem empresas como Instituto Algar, UniAlgar (Universidade), Algar Telecom, Algar Tech, Algar Farming, Algar Agro, Algar Mídia e Rio Quente (Turismo); atua na Argentina, Chile, Colômbia e Brasil; neste, efetua compra no Distrito Federal $(0,6 \%)$, e nos estados do Piauí $(5 \%)$, Tocantins (10\%), Pará (9\%), Minas Gerais (16\%) e Maranhão (31\%). Cf. FERREIRA, 2017, p.98.
[...] 200 milhões de reais, com unidade que possui modernos equipamentos numa área de $200.000 \mathrm{~m}^{2}$ e capacidade para armazenar 120 mil toneladas de soja e esmagar 500 mil toneladas de grão. Prevendo-se através deste investimento a instalação de uma indústria de refinamento de envase de óleo de soja, com investimentos na casa dos 77 milhões de reais. O projeto conta com matéria-prima advinda de plantios de soja na microrregião de gerais de Balsas e Porto Franco. Hoje a Algar Agro é a segunda maior exportadora do Maranhão. Toda a produção é transportada via ferrovia Norte-Sul, que segue até o Porto do Itaqui em São Luís. (ALGAR AGRO 2012 apud DIAS FILHO, 2013, p. 133).

Em entrevista concedida ao Jornal Pequeno, em 18 de Dezembro de 2006, o então prefeito do município de Porto Franco, Deoclides Macedo (PDT), lembrou que, antes, o que havia nessa cidade era apenas um pátio da Ferrovia Norte-Sul, que fazia transbordo da soja e, a partir de 2005 e 2006, foram feitos investimentos que resultaram na instalação da primeira processadora de soja do Maranhão. Depois, foi iniciada a operação de esmagamento de soja, o que resultou em uma fábrica de ração, que teve grande impacto na economia da região, ampliando a bacia leiteira e impulsionando, sobretudo, as 
atividades de suinocultura e avicultura nessa municipalidade.

De acordo com a Valec, atualmente são cinco empresas que possuem contrato de arrendamento e operação no Porto Seco de Porto Franco, a exemplo da Cargill (2000), Ceval (1999), ABC Inco (Algar Agro) (2005), Multigrain (2002) e Ceagro (2005). Apesar de ter sido a última a se instalar na cidade em destaque, a Algar Agro foi a empresa que mais impulsionou a economia de Porto Franco, pois as demais apenas operam armazenagem e transbordo de soja, não agregando valor ao produto e gerando, assim, poucos empregos, e consequentemente, o efeito multiplicador para a cidade ainda não registra incremento exponencial (OLIVEIRA; FERREIRA, 2017).

Ao analisar a Tabela 3 percebe-se que a criação do Distrito Agroindustrial teve grande importância para o crescimento econômico da cidade e do município de Porto Franco, pois no inicio dos anos 2000, quando as primeiras empresas começaram a se instalar a economia local era baseada, principalmente, no setor de serviços. Já em 2008, quando o processo de esmagamento de soja entrou em operação, antes exportada toda in natura, o setor industrial passou a comandar a economia, sendo responsável por mais de $60 \%$ do PIB municipal. Isso, em função dos citados grandes investimentos nesse setor econômico. Em 2014, registrou-se a redução de investimentos e forte queda em 2011 a qual derivou da crise mundial de 2008 e que concorreu para o arrefecimento da exportação das commodities de soja. Com efeito, o setor industrial voltou a crescer, porém lentamente. O setor de serviços, que teve boa evolução desde o início dos anos 2000, passou novamente a ser o maior responsável pela economia porto-franquina, correspondendo a mais de $43 \%$ da economia local em 2014, enquanto o setor industrial correspondeu a $29 \%$.

Tabela 3. Valor adicionado bruto por setor (por 1000)

\begin{tabular}{|c|c|c|c|c|c|}
\hline \multirow{2}{*}{ Ano } & Indústria & Agropecuária & Serviços & Administração \\
Pública & Total \\
\hline 2000 & 3.631 & 2.910 & 21.040 & & 13.221 \\
\hline 2004 & 3.465 & 14.879 & 29.591 & 61.581 \\
\hline 2008 & 160.929 & 16.455 & 59.442 & 31.687 & 268.513 \\
\hline 2011 & 77.862 & 22.561 & 76.195 & 48.424 & 255.042 \\
\hline 2014 & 116.385 & 31.343 & 171.854 & 71.282 & 390.864 \\
\hline TOTAL & 362.272 & 88.148 & 358.122 & 164.621 & 1.003 .156 \\
\hline
\end{tabular}

De acordo com a Tabela 4 constata-se que, assim como o setor de serviços, o setor da agropecuária manteve, de forma geral, crescimento contínuo, principalmente o inerente ao gado bovino de corte e ao leiteiro; percebe-se que a avicultura tem uma excelente evolução. Com exceção do ano de 2009, ano com índices pluviométricos bem acima da média, o rebanho de suínos teve quase que duplicada sua quantidade de 2015 em relação a 2013, o que foi impulsionado, também, pela instalação da fábrica de rações no município referido. Dos setores agropecuários, o que mais alternou, em se tratando da produtividade, foi o milho que não conseguiu manter um constante incremento, pois sofreu oscilações em decorrência das condições climáticas.

Tabela 4. Produção agropecuária de Porto Franco

\begin{tabular}{|c|c|c|c|c|c|}
\hline Ano & $\begin{array}{c}\text { Milho } \\
\text { (toneladas) }\end{array}$ & $\begin{array}{c}\text { Suíno } \\
\text { (cabeças) }\end{array}$ & $\begin{array}{l}\text { Avicultura } \\
\text { (cabeças) }\end{array}$ & $\begin{array}{c}\text { Bovino } \\
\text { (cabeças) }\end{array}$ & $\begin{array}{l}\text { Leite } \\
\text { (litros) }\end{array}$ \\
\hline 2004 & 2.379 & 2.332 & 14.086 & 73.378 & 9.066 \\
\hline 2008 & 1.954 & 2.964 & 42.982 & 71.563 & 9.661 \\
\hline 2010 & 2.159 & 3.291 & 19.025 & 75.997 & 10.259 \\
\hline 2013 & 2.310 & 2.868 & 281.420 & 94.693 & 12.783 \\
\hline 2015 & 2.307 & 5.277 & 657.328 & 99.384 & 13.416 \\
\hline
\end{tabular}

A Tabela 5 mostra a importância da criação do Distrito Agroindustrial e do Porto Seco para o crescimento econômico de Porto Franco, pois no período de 14 anos o Produto Interno 
Bruto desse município cresceu aproximadamente 1.300\% (IMESC 2012 e 2016). Mesmo com esse incremento, a participação dessa unidade subnacional no PIB do estado do Maranhão não chegou a 0,6\% uma vez que em 2010 equivalia a 0,49\% enquanto em 2014 correspondeu a $0,57 \%$ do total estadual ( $R \$ 76,843$ bilhões ou 1,3\% do PIB do Brasil), sendo que São Luís concentrava $34,26 \%$ do PIB maranhense e

[...] destacavam-se Imperatriz (7,55\%), Balsas (3,80\%), Açailândia (2,40\%), São José de Ribamar (2,10\%), Caxias (1,90\%), Timon $(1,87 \%)$, Bacabal $(1,39 \%)$, Santa Inês $(1,38 \%)$, Codó $(1,22 \%)$, Santo Antônio dos Lopes $(1,08 \%)$ e Tasso Fragoso $(1,04 \%)$. Os demais 205 municípios contribuíam, cada, com menos de $1 \%$ do PIB maranhense; isto implica que a economia do Maranhão é concentrada espacialmente [...]. (FERREIRA, 2017, p. 90).

Esse fato, contudo, é sinal de ascensão da economia de Porto Franco, o que está vinculado aos citados investimentos de empresas privadas. Por exemplo, a participação do VA industrial desse município passou de $\mathrm{R} \$ 15,183$ milhões em 2006 para $\mathrm{R} \$ 76,154$ milhões em 2010 e alcançou $\mathrm{R} \$$ 116,385 milhões em 2014, implicando em ascensão de 667\% entre 2006 e 2014 (OLIVEIRA; FERREIA, 2017).

Tabela 5. Produto Interno Bruto de Porto Franco (por 1.000)

\begin{tabular}{|c|c|c|c|c|c|c|}
\hline Ano & 2000 & 2005 & 2008 & 2011 & 2013 & 2014 \\
\hline PIB & 29.619 & 74.094 & 292.165 & 249.945 & 495.838 & 439.953 \\
\hline \multicolumn{7}{|c|}{ Fonte: IBGE } \\
\hline
\end{tabular}

\section{CONSIDERAÇÕES FINAIS}

O Porto Seco é, geralmente, instalado em cidades as quais possuem centralidade em relação a mercados produtores e consumidores e está situado em cruzamentos de importantes rodovias federais e estaduais, que possibilitam conexão como ferrovias visando à otimização do escoamento, conformando um sistema multimodal.

A cidade de Anápolis, por exemplo, foi beneficiada por sua situação geográfica, tornando-se entreposto entre a capital do país (Brasília) e a do estado de Goiás (Goiânia), gerando emprego e renda para a população local e servindo como polo indutor de sua região, tendo importante participação no PIB estadual. Porto Franco, por sua vez, teve importantes avanços econômicos, principalmente ao agregar valor à soja, através da indústria de esmagamento, melhorando indicadores locais. Estes, todavia, requerem estudos específicos para avaliar sua materialização.

Os programas de incentivos fiscais, nesse caso, são de grande valia para atrair investimentos para qualquer região. Em Anápolis, esses programas aliados à infraestrutura disponível e à localização geográfica, serviram como atrativos para as empresas as quais viram nessa cidade excelentes perspectivas de crescimento. Em Porto Franco, a agregação de valor à soja ainda é incipiente, porém determinante e constatou-se que o setor agropecuário se fortalece ao ter produtos, antes exportados in natura, sendo processados no próprio município, incrementando cadeias como da pecuária e avicultura, através dos subprodutos da soja.

Assim, a criação de incentivos fiscais poderá contribuir para a instalação de novas empresas na região as quais dinamizarão ainda mais e otimizarão o referido Porto Seco maranhense, aumentando O PIB e a renda municipal a partir de seu potencial de expansão, o que poderá resultar em uma melhoria na qualidade de vida das populações locais. Dessa maneira, conclui-se que assim como aconteceu com Anápolis (GO), o município de Porto Franco (MA) precisa ser estimulado, de forma que aproveite ainda mais a sua situação geográfica estratégica e sua infraestrutura multimodal na tentativa de atrair novos investimentos e novas empresas para incrementar o Distrito Agroindustrial com o intuito de ampliar tanto o escoamento quanto o processamento, principalmente da soja, objetivando agregar mais valor aos seus subprodutos para gerar renda na localidade, tornando as empresas competitivas dentro e fora do Maranhão, o que perpassa pela ampliação das demandas do MATOPIBA, do Porto do Itaqui e da economia do próprio país. Isso implica que, sua peculiaridade de enclave deve ser superada uma vez que não basta a economia crescer; faz-se necessário 
que ela seja mais inclusiva a fim de reduzir as

\section{REFERENCIAS}

[1] Araújo, Carlos. A importância dos portos secos na logística aduaneira do Brasil. In: Comexblog.com. 17 maio 2011. Disponível em: http://www.comexblog.com.br/logística/aimportancia-dos-portos-secos-na-logísticaaduaneira-do-brasil-uma-visão-geral/. Acesso em 16 out. 2018.

[2] Associação Brasileira de Movimentação e Logística (Abml). Conceitos do Operador Logístico: [s.I.]. 1999. Disponível em: http://www.abml.org.br/website/downloads/conceit oDoOperadorLogistico.pdf, acesso: 22 maio 2017.

[3] Belfort, R. M.; Silva, J. L. G. da; Oliveira, E. A. de A. Q. O desenvolvimento do município de Porto Franco - MA: A influência dos conglomerados corporativos da cadeia agroindustrial. In: Encontro DE Iniciação Científica, 17., 2012, Taubaté. Anais... Taubaté: Unitau, 2012. p. 6-7. Disponível em: http://www.unitau.br/enic/trabalhos/MPH1606.pdf, acesso: 02 jun 2017.

[4] Bernardes, Genilda D'arc. Memória e lugar: estudo da memória urbana da vila fabril, Anápolis/GO (1940-1970). Anais... IX Seminário DE Pbic - Volume 1 - Artigo - Multidisciplinares, 2011.

[5] Brasil. Decreto no 4.543, de 26 de dezembro de 2002, alterado pelo Decreto no 4.765, de 24 de junho de 2003. Regulamento Aduaneiro. Distrito Federal, 2003. Disponível em: http://www.atlantaaduaneira.com.br/RegulamentoA duaneiro.html, acesso: 22 maio 2017.

[6] Correia Filho, Francisco; et al. Projeto cadastro de fontes de abastecimento por água subterrânea, estado do Maranhão: relatório diagnóstico do município de Porto Franco. Teresina: CPRM - Serviço Geológico do Brasil, 2011.

[7] Dias Filho, Humberto S. Reflexos da agricultura tecnificada no sudoeste maranhense: uma abordagem a partir da instalação e funcionamento da ALGAR/AGRO no Município de Porto Franco-MA. In: SOUSA, Jailson de M. (Org.). O regional e o urbano no sul do Maranhão: delimitações conceituais e realidades empíricas. Imperatriz, MA: Ética, 2013. p. 122-154.

[8] Dias, Simone Silva. O papel de Anápolis GO no contexto do eixo Goiania-Anápolis-Brasília. Dissertação (Mestrado em Geografia)-Programa de Pós-Graduação em Geografia, Universidade de Brasília. Brasília, 2011.

[9] Empresa Brasileira DE Pesquisa Agropecuária (Embrapa). Gite: Matopiba. Disponível em: http://www.embrapa.br/gite/projetos/matopiba, acesso: 10 junho 2017. desigualdades sociais e espaciais.

[10] Federação Das Indústrias Do Estado De São Paulo. Portos secos. Disponível em www.fiesp.com.br/trasnporte-e-logística/portossecos/. Acesso em 16 out. 2018.

[11] Ferreira, Antonio J. de A. A reestruturação urbana maranhense: dinâmica e perspectivas. São Luís: Edufma, 2017.

[12] _. A evolução da Geografia dos Transportes no estado do Maranhão, Brasil: de ancoradouro a sistema multimodal. In: Encuentro De Geografos de América Latina, 12., 2009, Montevideo. Anais... Montevideo, 2009. Diponível em:

http://www.egal2009.easyplanners.info/programaEx tendido.php?sala-=A20-\%2014\&dia-Domingo-

Areas-1-2-3-4-\# [ISBN 978-9974-8194-0-5]>, acesso: 23 junho 2010.

[13] Freitas, J. F.. A expansão urbana e a segregação socioespacial em Anápolis - Goiás. Dissertação (Mestrado em Ciências Humanas), Instituto de Ciências Humanas. Universidade de Brasília. Brasília, 2004.

[14] Gil, Antonio C. Métodos e técnicas de pesquisa social. 6aㅡ ed. São Paulo: Atlas, 2008

[15] Goiás. Governo do Estado; SIC, Secretaria de Indústria e Comércio do Estado de Goiás. Produzir. Goiás: SIC, 2012. Disponível em: http://www.sic.goias.gov.br/post/ver/112604/produz ir, acesso: 23 maio 2017.

[16] Instituto De Pesquisa Econômica Aplicada (Ipeadata). PIB Municipal. Disponivel em <http://www.ipeadata.gov.br>, acesso: 23 maio 2017.

[17] Instituto Brasileiro de Geografia e Estatística (lbge). Produto Interno Bruto dos Municípios - 2010: Banco de dados: Disponível em http://www.ibge.gov.br/, acesso: 20 maio 2017.

[18] Istoé Dinheiro. O Brasil se prepara para colher uma safra recorde e para exportar US\$ 52 bilhões em produtos agrícolas em 2008: com preços em alta, a euforia está de volta ao campo. Disponível:

http://www.istoedinheiro.com.br/noticias/1368_A+R EVOLUCAO+VERDE, acesso: 22 maio 2017.

[19] Instituto Maranhense De Estudos Socioeconômicos e Cartográficos (Imesc). Produto Interno Bruto dos Municípios do Estado do Maranhão: período 2006 a 2010. São Luís: IMESC, v. 8, 2012

[20] _. Produto Interno Bruto dos Municípios do Estado do Maranhão: período 2010 a 2014. São Luís: Imesc, v. 10. 2016.

[21] Lakatos, Eva M.; Marconi, Marina de A. Metodologia do trabalho científico: procedimentos básicos, pesquisa bibliográfica, projeto e relatório, 
publicações e trabalhos científicos. São Paulo: Atlas, 2009.

[22] Louzada, Cláudia Espindola Cabral. Panorama dos portos secos no Brasil: avaliação e perspectivas. Dissertação (Mestrado em Engenharia Industrial), Pontifícia Universidade Católica do Rio de Janeiro, Rio de Janeiro, 2005.

[23] Miranda, Evaristo E. de; Magalhães, Lucíola A.; Carvalho, Carlos A. de. Um sistema de inteligência territorial estratégica para o Matopiba. Campinas: Embrapa, 2014.

[24] Oliveira, J. G. da S.; Ferreira, A. J. de A. Os Portos Secos de Anápolis (GO) e Porto Franco (MA): confluências e implicações econômicas e socioespaciais. In: Simpósio Nacional DE Geografia Urbana, 15., 2017, Salvador. Anais... Salvador: Ufba, 2017. 20p.

[25] Paschoal, J. A. R. Tem sido bom pra Goiás?: Goiânia: Jornal Opção. Entrevista concedida a Cezar Santos. Disponível em $<$ http://www.jornalopcao.com.br/posts/reportagens/ tem-sido-bom-pra-goias>, acesso: 23 maio 2017.

[26] Pereira, Caroline N.; Porcionato, Gabriela L.; Castro, César N. de. Aspectos socioeconômicos da região do MATOPIBA. In: Boletim regional, urbano e ambiental. Brasília: IPEA, n. 18, jan. jun, 2018, p. 47-59.

[27] Porter, Michael E. Vantagem competitiva: criando e sustentando um desempenho superior. Rio de Janeiro: Campus, 1989.

[28] Rodrigues, Alexandre D. Plataforma Logística: competitividade e futuro. Secretaria de Estado de Gestão e Planejamento (SEGPLAN). $2004 . \quad$ Disponível em <http://www.seplan.go.gov.br/sepin/pub/conj/conj2 /04.htm\#_ftn2>, acesso: 23 maio 2017.

[29] Slack, N.; Lewis, M. Operations strategy. Londres: Pitman, 2002. 


\section{Gapítulo 10}

GOVERNANÇA INTERFEDERATIVA NA RMVPLN/SP: UM CAMINHO DE COLABORAÇÃO DOS ENTES FEDERADOS

\section{Priscila Maria de Freitas}

Resumo:As Regiões Metropolitanas são uma realidade cada dia mais evidente no território brasileiro. E para compreender a composição e gestão dessas regiões se faz necessário analisar o contexto político e socioeconômico brasileiro e perceber que os municípios possuem atributos e propostas de ações distintas. Assim sendo, este trabalho parte da hipótese de que é possivel se propor outro olhar para os arranjos metropolitanos visando à governança interfederativa. Buscando em pesquisa bibliográfica como cidades com diferentes características nas suas realidades, participam do processo de gestão da Região Metropolitana do Vale do Paraíba e Litoral Norte/SP. Demonstrando que o atual modelo existente acentua as disparidades municipais, considerando assim a cooperação entre os pares um caminho possível para uma efetiva governança interfederativa.

Palavras-chave: governança, cooperação, RMVPLN. 


\section{INTRODUÇÃO}

As Regiões Metropolitanas são uma realidade cada dia mais evidente no território brasileiro. Essa institucionalização recente (após a década de 1970) de diversas Regiões Metropolitanas pode ser constatada por diversos fatores, seja pela elevada concentração populacional ou mesmo concentração de PIB nas regiões metropolitanas, ou ainda, pela recente promulgação de uma lei federal denominada Estatuto da Metrópole (Lei n. 13.089/2015) com o objetivo de regulamentar os parâmetros para a instituição de novas regiões metropolitanas e instrumentos para a governança interfederativa. Conforme afirma Jeroen Johannes Klink existem diversos arranjos institucionais nas regiões metropolitanas brasileiras, citando dois arranjos especificamente como o arranjo estadualizado e o municipalismo regionalizado; os quais podem ser explicados pelo próprio Klink.

O arranjo estadualizado, que se configurou em pleno regime autoritário, teve um viés tecnocrata e um alto grau de centralização financeira e de tomada de decisões, com o principal órgão (o conselho deliberativo) dominado pelos representantes indicados pelo governo federal-estadual. KLINK, 2009, p. 419 (grifo da autora).

Por outro lado, há uma vertente, que poderíamos rotular de municipalismo regionalizado, de acordo com a qual o consórcio público representa um embrião de um novo modelo institucional para a governança metropolitana. Nessa perspectiva, a flexibilidade e o grau de abertura da nova lei proporcionariam um ambiente favorável à experimentação e à aprendizagem, com novos arranjos mais amplos de colaboração interfederativa, mas sempre impulsionada pela vontade autônoma dos municípios. KLINK, 2009, p. 424 (grifo da autora).

Este estudo, agora proposto, busca compreender se dentro do arranjo estadualizado há a possibilidade de dinâmicas colaborativas nas regiões metropolitanas brasileiras. Desta forma, se faz necessário compreender como se dá essa governança interfederativa? Qual a relação existente e possível entre os entes federados? Como se configuram esses municípios que compõem a mesma Região Metropolitana?
Responder essas questões implica em compreender o contexto político e socioeconômico que o Brasil e suas regiões metropolitanas estão inseridos, e também qual a realidade dos municípios brasileiros e a relação entre eles. Ou seja, compreender as diferenças entre os municípios brasileiros em termos das dinâmicas sociais, econômicas e direcionamentos de ações e no que implica estas disparidades territoriais. Buscando compreender, no caso específico da Região Metropolitana do Vale do Paraíba e Litoral Norte, se cidades com diferentes atributos nas suas realidades participam equitativamente do mesmo processo de gestão territorial.

Inicialmente, apresenta-se o contexto político e socioeconômico que o Brasil e suas regiões metropolitanas estão inseridos. Demonstrando, por autores tais como Platão, Espinoza, Marx e Weber, qual a função e finidade do Estado; qual seja, ser fruto do contexto social no qual está inserido, e ser responsável por zelar pelos espaços públicos e pelos habitantes; regulamentando os espaços públicos e privados, e as ações dos indivíduos de um determinado território.

Esse Estado Brasileiro, ou essa esfera de governança, está atualmente envolta pelo sistema capitalista e mais especificamente ao momento neoliberal deste sistema. Isto implica em uma demanda política de diminuição das ações estatais favorecendo a lógica do livre mercado. Este fato, somado a frágil formação política brasileira, gera ações governamentais pontuais e fragmentadas, que não contemplam um planejamento de médio a longo alcance das fragilidades existentes no território.

Neste contexto se inserem as atuais Regiões Metropolitanas brasileiras. E com um olhar holístico que se utiliza aqui o conceito de Milton Santos sobre "território usado" para abordar o território de governança interfederativa. Assim esse território regional é compreendido como objeto e objetivo das ações estatais.

A contemporaneidade nos traz também que estas ações de Estado devem estar previstas em legislações, desta forma a região metropolitana deve seguir os instrumentos de governança interfederativa previsto. Esses instrumentos trazem o conceito de que a governança interfederativa corresponde à gestão realizada entre entes federados, compartilhando responsabilidades e ações 
num mesmo território, visando o atendimento das funções públicas de interesse comum nesse território.

Para que seja possível atingir essa governança interfederativa, esse processo de gestão deve ocorrer de forma cooperativa, pois cada município possui uma significação diferente. Ou seja, cada município de uma mesma região possui realidade distinta dos demais, sendo fruto de um conjunto de relações sociais dadas nesses espaços, como também cada território municipal visa a uma forma distinta de se inserir no mercado econômico nacional e internacional. Assim, os municípios possuem atributos distintos e intencionalidades de ações diferentes.

Ao se estudar o caso específico da Região Metropolitana do Vale do Paraíba e Litoral Norte, ficam nítidas essas diferenças de significação. Para exemplificar tais disparidades, foram analisados mapas e dados dessa região, PIB, área urbanizada e densidade demográfica.

As Regiões Metropolitanas brasileiras partem do pressuposto que terão governança interfederativa, contudo ao se analisar o contexto político brasileiro e os atuais instrumentos de planejamento e gestão metropolitanos nota-se que não são considerados os diferentes atributos dos entes federados entre si e que compõem a mesma região. O atual modelo acaba por reafirmar e acentuar estas diferenças municipais. Desta forma, considera-se que a cooperação entre os pares, possibilitando instrumentos de gestão cooperativos dos entes federados díspares, seja um caminho para uma efetiva governança interfederativa.

\section{GOVERNANÇA METROPOLITANA}

INTERFEDERATIVA

O Estado é um agente social num determinado espaço, na medida em que tem o papel de regulador das atividades dos demais agentes que atuam no território. A definição de Estado pode ser dada por um conjunto de pensadores, como Platão, que "ao propor um modelo de 'Estado Ideal', separa o público do privado para dizer que o Estado é o único responsável por zelar pelo público" (STEINBERGER, 2013, p. 33); e Espinoza que "trata o Estado como instância de poder reguladora das individualidades e voltada para a coletividade dos homens que residem em um mesmo território"
(STEINBERGER, 2013, p. 33); ou mesmo Marx ou Weber que trazem uma visão mais política sobre o Estado.

Marx introduz o 'Estado Classista' afirmando que ele não é um poder criado fora da sociedade de classes antagônicas, mas um produto dela que assume certa independência para garantir 0 interesse comum e mantê-la dentro dos limites da ordem. Weber considera o Estado como resultado do processo histórico-sociológico da concentração de poder de um agrupamento político que reivindica 0 monopólio da coação física em um determinado território geográfico. STEINBERGER, 2013, p. 33.

Assim, podemos afirmar que o Estado é fruto do contexto social no qual está inserido, sendo responsável por zelar pelos espaços públicos e pelos habitantes; regulamentando os espaços públicos e privados, e as ações dos indivíduos de um determinado território. Atualmente, somado aos conceitos iniciais, o Estado está envolto ao sistema capitalista e mais especificamente ao momento neoliberal deste sistema, desta forma o Estado se vê frente a um forte agente que também atua no território e demanda a diminuição da ação do Estado, o mercado. Sob a lógica do livre mercado, há a solicitação pelos agentes hegemônicos da diminuição do alcance do Estado, ou seja, que o Estado não atue tão incisivamente e que se mantenha distante das relações sociais e econômicas dadas no território.

Contudo o sistema capitalista vivencia crises frequentes e nestes momentos no qual a sociedade se encontra num estado de colapso social e, principalmente econômico, o Estado é convocado a restaurar a ordem, ou melhor, a estrutura mínima necessária para a manutenção das atividades mercadológicas. Sob este contexto o Estado tem a perspectiva de ações por meio de políticas públicas, que podem gerar ora a manutenção e (re)produção das condições do sistema neoliberal, ora a estruturação, dentro da democracia representativa e participativa, de políticas redistributivas

Nesse contexto encontra-se o Estado Brasileiro que, até 2014, demonstrava a busca pela valorização cultural e a afirmação de um estado democrático com políticas redistributivas, mesmo inserido num momento de globalização neoliberal, de foco ao 
caminhar fluído do livre mercado. Somado a esse contexto econômico e político internacional, no Brasil deve-se considerar a sua formação histórica. Conforme demonstra Jessé Souza a sociedade é formada por ideias construídas, como o mito do "homem cordial" (HOLANDA, 1995), que justifica algumas posturas atuais de dominação da elite brasileira da política, da economia e da comunicação. Jessé afirma que a estrutura de classe vai além da questão econômica, sendo no sistema capitalista inteiramente vinculada ao tempo (despendido às tarefas intelectuais) e ao conhecimento incorporado. Desta forma, cria-se uma rede invisível que traz uma consequências práticas e políticas latentes "o que existe aqui são acordos e consensos sociais mudos e subliminares, mas por isso mesmo tanto mais eficazes, que articulam, como que por meio de fios invisíveis, solidariedades e preconceitos profundos e invisíveis" (SOUZA, 2003, p. 71). Essas posturas tendenciosas das ações do Estado brasileiro não possibilitaram estruturar um projeto de nação, que é uma proposta de identidade nacional; como também uma proposta de Estado, já que a partir deste projeto de nação se traça as futuras decisões e planejamentos de médio e longo prazo a serem realizados pelo Estado.

A criação de Regiões Metropolitanas (RMs) no Brasil tem sua relevância institucional na década de 1970, sob o regimento de um governo federal autoritário. Nota-se que as ações do Estado possuem um contexto político, econômico, social e também territorial. "Nessas condições, a organização territorial do Estado se torna, ao mesmo tempo, arena e objeto das contendas sociopoliticas nas escalas regionais e locais" (BRENNER, 2010, p. 555). Essa criação, ou melhor, institucionalização das Regiões Metropolitanas no Brasil, desde a década de 1970 até o surgimento do Estatuto da Metrópole, não foram acompanhadas de mecanismos de governança entre os diferentes entes federados e suas escalas de atuação. Qual seja a escala de domínio de um ente federal, seja ele municipal, estadual ou federal; somada as questões que influenciam as dinâmicas territoriais e que são atuantes em diversas escalas, tal como o fator econômico e político. Esta é a atual situação da governança metropolitana brasileira, da qual o autor conclui na sua análise que

os problemas de governança urbana não podem mais ser confrontados simplesmente em escala urbana, como dilemas de regulação municipal ou mesmo regional, mas devem ser analisados também em escala nacional, supranacional e global do poder territorial do Estado, pois é basicamente nessas escalas supraurbanas que a geografia política intensamente contraditória do neoliberalismo é configurada. BRENNER, 2010, p. 556.

Aqui cabe pontuar a concepção de território, para além desta concepção administrativa. Entende-se território conforme conceitua Milton Santos, o termo 'território usado', entendido como resultado da organização social vinculadas ao processo de competição econômica e como uma arena onde se desenrolam os conflitos dados entre os diversos agentes sociais que direcionam a conformação deste espaço. Desta forma, este território é objeto e objetivo das ações do Estado, uma vez que o Estado é um agente social que regulamenta formas de apropriação e define políticas públicas que irão influenciar no modo de vida dado sobre o território.

Para abordarmos a governança interfederativa cooperativa foram demonstrados primeiramente os desafios referentes ao território e quanto à gestão do Estado brasileiro, sendo que estes desafios se expressam na relação dos entes federados que compõem uma mesma região metropolitana, pois apesar de formalmente serem equivalentes, não são análogos no processo de gestão da RM. Somado a estes, tem-se também outro desafio relacionado à significação dada no espaço, abordado por Milton Santos.

A atividade coletiva sempre supôs a criação de um Capital Geral, suporte do esforço coletivo diferenciado. Mas, desde a irrupção do capitalismo, o processo conheceu uma evolução característica. De início, quando a natureza era pouco modificada pelo homem, ela era socialmente transformada, socialmente possuída e socialmente apropriada. Hoje, diante da natureza artificializada das cidades, o Capital Geral produzido coletivamente é gerido em nome da coletividade que o produziu, mas não é mais socialmente possuído, e está exclusivamente a serviço de alguns. Sua apropriação efetiva e seu uso efetivamente produtivo são seletivos. Isto atribui, na cidade, uma significação diferente, específica, diferencial a cada indivíduo, a cada grupo, a casa firma, a cada instituição e, ao mesmo 
tempo, a cada distrito, a cada bairro, a cada rua. SANTOS 1994, p. 134 (grifos da autora).

Milton Santos nos ajuda a compreender que cada território, exemplificado pelo autor por um distrito, um bairro ou uma rua, possui uma significação diferente. Essas diferenças se dão pela seletividade na apropriação de bens e serviços produzidos coletivamente. Esse conceito auxilia na compreensão de que os territórios, ou mesmo entes federados, possuem uma significação diferente.

A significação diferente, específica, diferencial entendida por Milton Santos nos auxilia a compreender o motivo pelo qual a cidade de São José dos Campos foi selecionada para ser a capital da Região Metropolitana do Vale do Paraíba e Litoral Norte. Esta RM é composta por 39 municípios, destes a cidade de São José dos Campos não se encontra geograficamente centralizada na metrópole, nem mesmo possui acesso ou formas de diálogo com os demais 38 municípios. A escolha da capital dessa RM se deu pela significação que a cidade de São José dos Campos possui em relação às demais cidades. Na próxima seção iremos demonstrar alguns os dados que compõem a construção dessa significação.

A governança interfederativa de forma cooperativa corresponde à gestão realizada de modo colaborado entre entes federados, compartilhando responsabilidades e ações num mesmo território, visando o atendimento das funções públicas de interesse comum nesse território e gerando benefícios para os habitantes desta metrópole.

O atual marco regulatório da política urbana contemporânea brasileira, o Estatuto da Cidade (Lei Federal 10.257/2001) que estabelece diretrizes gerais da política urbana, já prevê dentre suas diretrizes no inciso III do artigo $2^{\circ}$ a cooperação entre os governos em atendimento ao interesse social. Assim a cooperação entre entes federados visando a um bem comum já é prevista em norma legislativa desde 2001.

O Estatuto das Metrópoles (Lei Federal 13.089/2015) traz orientações para a institucionalização de novas Regiões Metropolitanas e de Aglomerações Urbanas e outras diretrizes para o planejamento, gestão e execução dos instrumentos de desenvolvimento integrado para as RM visando à plena execução das funções públicas de interesse comum. Esses instrumentos descritos no artigo $9^{\circ}$ da lei federal incluem a elaboração de um Plano de Desenvolvimento urbano Integrado (PDUI), fundos públicos, convênios de cooperação, entre outros. Enquanto no artigo $8^{\circ}$ são abordados os quatros tópicos da estrutura da governança interfederativa, que são: instância executiva dos entes federados, instância deliberativa com representação da sociedade civil, agência técnico-consultiva e sistema para alocação de recursos e prestação de contas.

Desta forma, para a realização da governança interfederativa além dos desafios referentes ao território e quanto à gestão do Estado brasileiro, a RM deve seguir os regulamentos normativos e enfrentar as diferenças de significação entre seus entres federados, fato este que acentua as diferenças das realidades socioeconômicas existentes.

\section{CIDADES DÍSPARES COMPONDO UMA METRÓPOLE: O CASO DA RMVPLN}

No Estado de São Paulo foram instituídas seis Regiões Metropolitanas e duas aglomerações urbanas. A RMVale foi instituída pela Lei Complementar Estadual n. 1.166/2012. O artigo $2^{\circ}$ afirma que o objetivo da RMVale é possibilitar a cooperação entre os diversos níveis de governo, integração do planejamento e redução das desigualdades regionais, além de citar o Conselho de Desenvolvimento, a localização e funcionamento da agência técnico-consultiva, na forma de autarquia. Nota-se que a Lei que institui a RMVale contempla as ferramentas institucionais legalmente instituídas, como também traz para sua instrumentalização o princípio de cooperação entre os entres federados.

Este estudo buscou compreender a governança interfederativa especificamente da Região Metropolitana do Vale do Paraíba e Litoral Norte (conhecida oficialmente como RMVPLN, mas será aqui citada como RMVale). O território dessa região, com 39 municípios, possui uma extensão de 16.192,67 quilômetros quadrados, conforme dados do IBGE de 2014, além de possuir muitas divergências, tanto física quanto socioeconômicas. 
Figura 1 - mapa da divisão administrativa da RMVale.

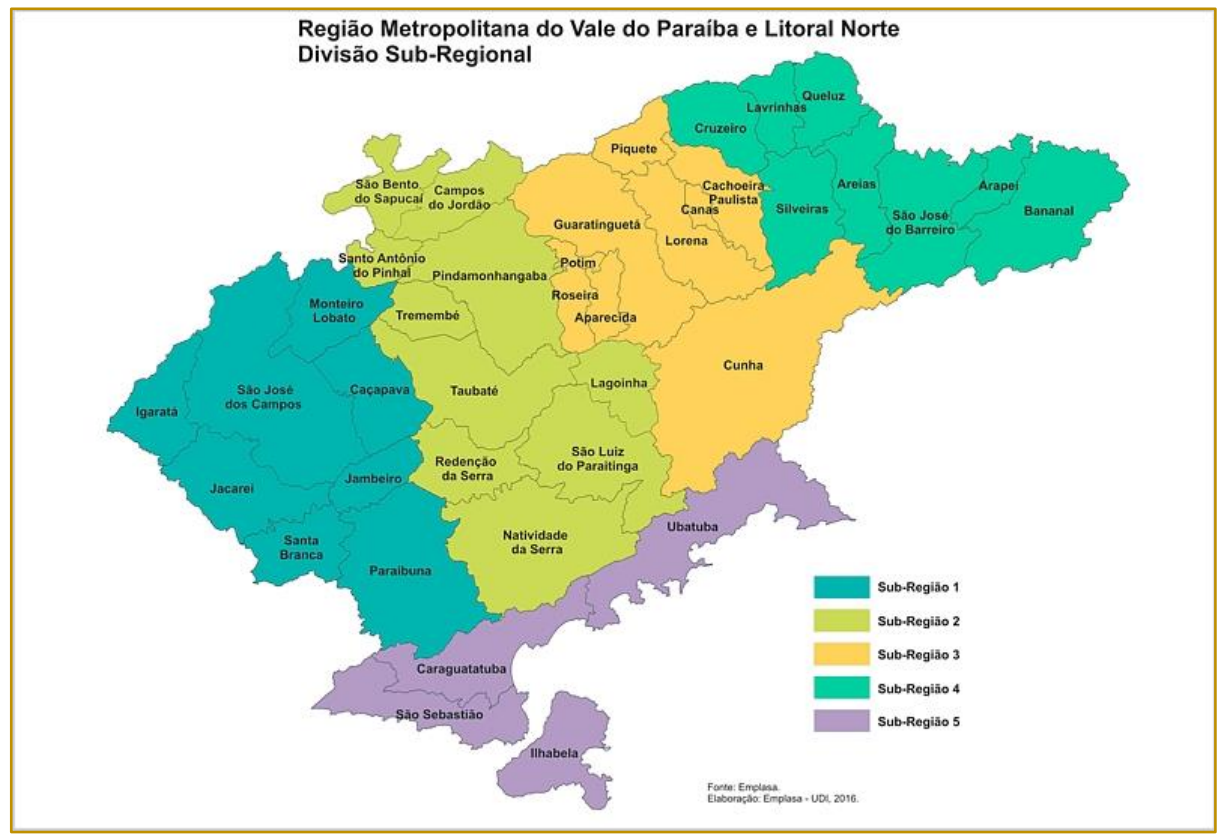

Fonte: Emplasa

(https://www.emplasa.sp.gov.br/Cms_Data/Sites/EmplasaDev/Files/Conselhos/Vale/lmagens/mapa_RMVPLN.jpg )Acesso: 29maio2017

A Figura 1 demonstra que a cidade de São José dos Campos não está situada de forma centralizada, fato que possibilitaria uma equidade de acesso e comunicação entre os municípios que compõem uma mesma região, ou seja, se a sede de uma região está centralizada geograficamente, ou possui uma estrutura de comunicação tal que permita o acesso as informações geradas pela agência técnico-consultiva e um diálogo equânime entre os entes federados e suas demandas. Contudo a sede foi determinada como uma cidade deslocada, pendendo para uma das extremidades dessa RM, mais especificamente na direção da cidade e RM de São Paulo. Isto se deve ao fato das diferentes significações, ou seja, São José dos Campos recebeu ao longo do tempo mais investimentos financeiros e incentivos para um avanço no processo de urbanização que as demais cidades que hoje compõem essa RM. E tal fato gerou um atrativo para empreendedores e geradores de bens e serviços; estes por sua vez geraram uma concentração de PIB e um elevado índice de densidade populacional

Essas diferentes significações entre os entes federados vêm de uma resultante histórica, que influencia as atuais dinâmicas postas. Assim, em virtude de conjunturas históricas, hoje a cidade de São José dos Campos é a cidade da RMVale que possui a maior densidade populacional e o maior PIB; portanto esta cidade foi determinada pela lei que instituiu a RMVale para ser a sede e o local de instalação da agência técnicoconsultiva. Desta forma, a significação entre os entes federados se torna base para tomada de decisões e direcionamento de ações entre estes. 
Figura 2 - mapa do sistema socioeconômico da RMVale.

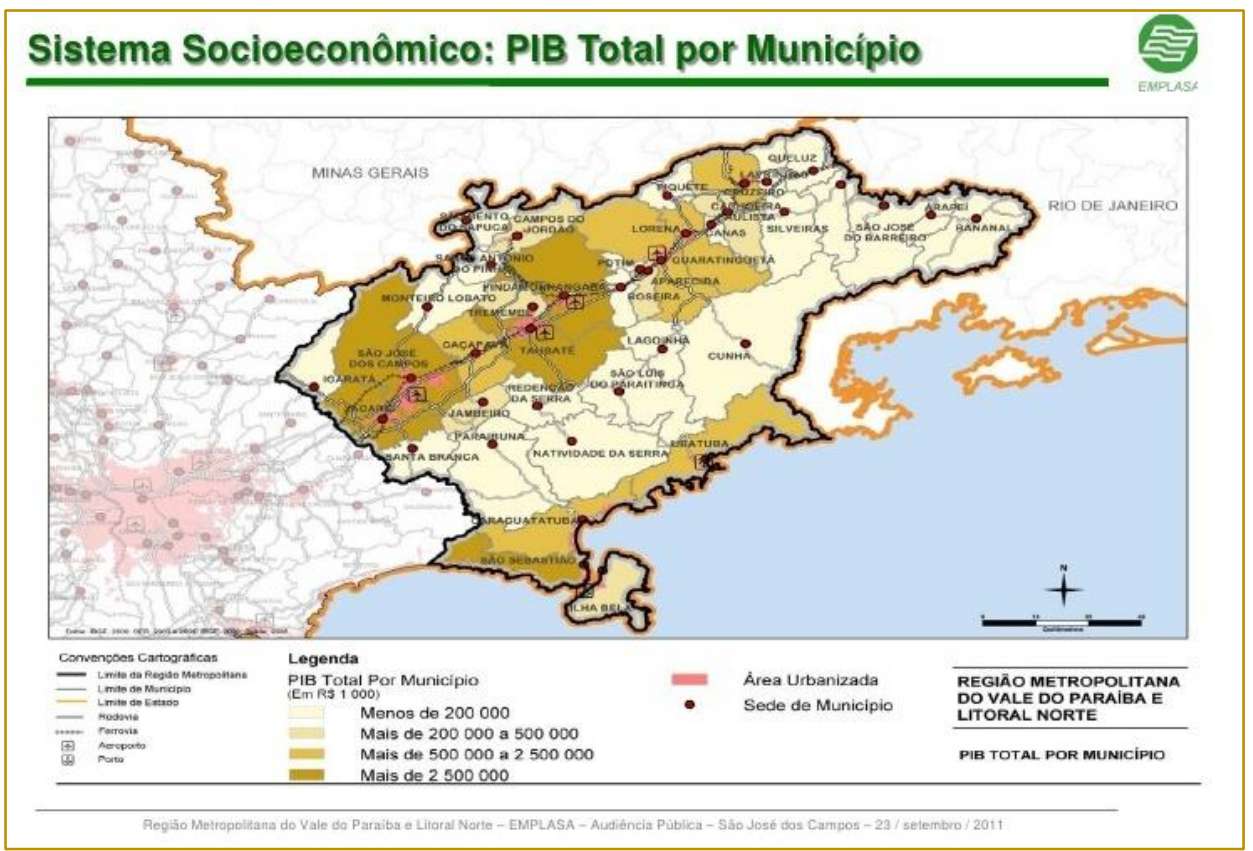

Fonte: EMPLASA (https://image.slidesharecdn.com/rmvaledoparabaelitoralnorte-final-110925041052phpapp02/95/rm-vale-do-paraba-e-litoral-norte-final-51-728.jpg?cb=1316923977)

Acesso: 29maio2017

A Emplasa é a Empresa Paulista de Planejamento Metropolitano, que auxilia o governo do Estado no processo de gerenciar os dados relacionados às Regiões Metropolitanas e Aglomerados Urbanos. Esta empresa desenvolve levantamentos de dados e elabora diversos mapas, dentre eles esse mapa aqui apresentado sobre a concentração de PIB por municípios da RMVale. Nesse mapa, nota-se na legenda que os municípios foram divididos em quatro faixas de concentração de PIB, sendo o menor valor (200.000) correspondente a 8\% do maior valor apresentado. Isto demonstra uma grande concentração de riqueza e uma disparidade entre as realidades destes entes federados.

Outras duas questões demonstradas nesse mapa é que a concentração do PIB se dá nas cidades localizadas ao longo da Rodovia Presidente Dutra e nas cidades litorâneas. E que as cidades da RMVale possuem poucas áreas consideradas como urbanizadas, demarcadas em rosa no mapa.

Comparando os dois mapas aqui apresentados, sendo o primeiro com a divisão administrativa da RMVale e suas sub-regiões e o segundo da relação do PIB total por município, nota-se que a demarcação das sub-regiões não seguiu a realidade socioeconômica posta, em sua maioria, já que a sub-região 5 demarca a concentração de riqueza do litoral norte. Isto, por um lado, é decorrente do discurso de dinamizar economicamente o território, fazendo com que os municípios que possuem realidades diferentes se vejam na mesma regionalização. Mas, por outro lado, não valoriza particularidades deste território, ou seja, ao se afirmar que os entes federados são diferentes entre si e demarcar estas divergências em sub-regiões poderia se possibilitar uma cooperação entre pares, criando uma dinâmica diferente em toda a RM; ao invés de apenas colocar em disputa entes federados com realidades tão díspares.

Demonstrar essa disparidade regional em números se torna um desafio, considerando as realidades existentes em cada município sendo fruto de um conjunto de relações sociais dadas nesses espaços, como afirma Lefebvre: "toda realidade dada no espaço se expõe e se explica por uma gênese no tempo. Mas uma atividade que se desenvolve no tempo (histórico) engendra (produz) um espaço e somente num espaço assume uma "realidade" prática, uma existência concreta" (LEFEBVRE, 2006, p. 97). Desta forma, não é possivel demonstrar em apenas um indicador essa existência concreta, mas a título de exemplificar a disparidade existente e reforçada pelos discursos e ações da 
RMVale, vamos abordar a densidade demográfica.

Levantando todos os dados sobre a densidade demográfica da RMVale percebese que a distribuição espacial deste indicador é muito similar à conformação espacial dada pelos valores do PIB. A densidade total da Região Metropolitana é de 152,90 habitantes $/ \mathrm{Km}^{2}$ (todos os dados aqui demonstrados de densidade demográfica são relativos ao ano de 2016). Comparando esse valor aos 39 municípios tem-se que 64\% destes, ou seja, 25 municípios possuem uma densidade demográfica muito inferior a 152,90 habitantes/ $/ \mathrm{Km}^{2}$.

Comparando os cinco maiores municípios da RMVale em extensão territorial obtemos um gráfico com as cidades de Cunha, São José dos Campos, Natividade da Serra, Paraibuna e Guaratinguetá.

Figura 3 - gráfico comparativo da densidade dos cinco municípios mais extensos da RMVale

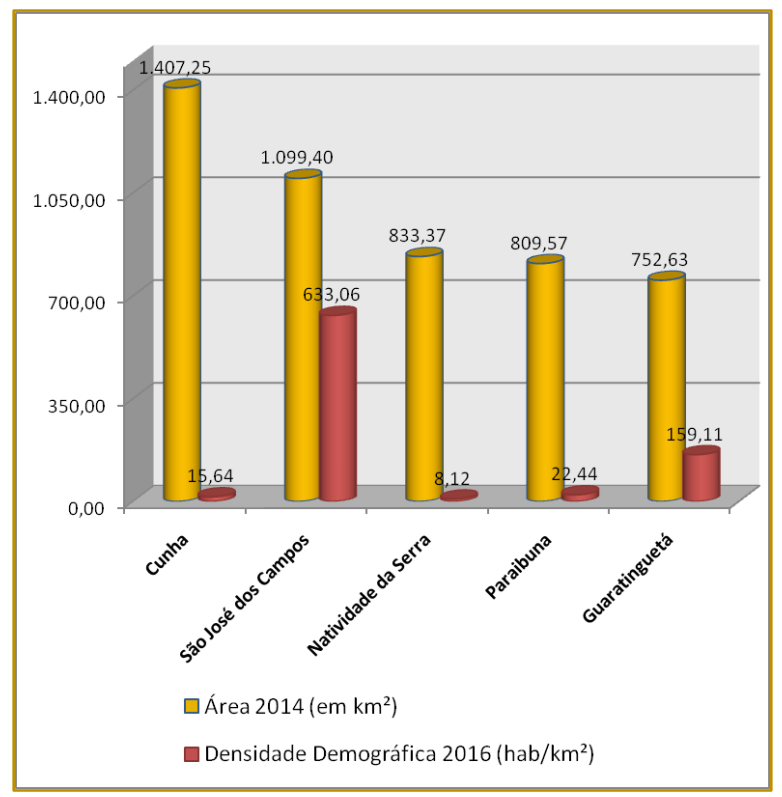

Elaborado pela autora a partir de dados obtidos pela EMPLASA

A Figura 3 demonstra os maiores e menores valores de densidade demográfica da Região Metropolitana. A cidade de Guaratinguetá possui uma densidade próxima ao valor geral da RMVale e a cidade de São José dos Campos tem um índice maior que quatro vezes o valor geral da região. Os municípios de Cunha, Natividade da Serra e Paraibuna possuem uma densidade menor que um quarto do valor geral da região. Esse gráfico é significativo, já que nele também $60 \%$ dos municípios possuem uma densidade demográfica muito inferior a 152,90 habitantes $/ \mathrm{Km}^{2}$, da mesma forma como acontece na RM.

Desta forma, quando se afirma nos amplos meios de comunicação que a Região Metropolitana do Vale do Paraíba e Litoral Norte é uma região urbana, economicamente dinâmica, possuindo um parque industrial e destacando-se no setor automobilístico, aeroespacial, entre outras, como afirma o site www.cidadespaulistas.com.br, nota-se que a imagem retratada não é equivalente a realidade, a existência concreta, da maioria dos municípios. Como demonstrado pelos indicadores, mais de $60 \%$ dos municípios da RMVale possuem baixa densidade demográfica, baixo PIB e pouca área urbanizada. Tais indicadores se tornam um desafio para a gestão interfederativa de forma cooperativa, já que no processo de gestão esses municípios, considerados de menor significação, perdem o poder de força e tomada de decisão. Desta forma, entes federados de mesmo nível de governança se apropriam dos instrumentos de gestão de formas desiguais. Não se está excluindo dessa discussão os impactos que a lógica político-partidária brasileira também atua no processo de gestão e tomada de decisão estatal, mas o foco dessa discussão é para além. Está voltado para o desafio posto para o modelo dado para a governança interfederativa das Regiões Metropolitanas brasileiras. 


\section{CONSIDERAÇÕES FINAIS}

Atualmente o Estado brasileiro está envolto pelo sistema capitalista e mais especificamente pelo momento neoliberal deste sistema, o que institui uma demanda constante pela diminuição da ação do Estado e a manutenção da lógica do livre mercado. Esta conjuntura se reflete nas regiões metropolitanas que representam uma das esferas de planejamento e gestão sobre o território.

O território, por sua vez, é compreendido como produto e meio das relações sociais dadas neste espaço. Assim, as regiões metropolitanas são fruto e arena das relações entre os diferentes atores $e$ interesses existentes nesse contexto. Somado a este conceito tem-se as diferentes significações entre os espaços, dadas pela seletividade na apropriação de bens e serviços produzidos coletivamente. Desta forma, os entes federados que compõem uma RM podem se apropriar dos instrumentos de gestão de formas desiguais, já que estes possuem REFRÊNCIAS

[1] Brenner, Neil. A globalização como reterritorialização: 0 reescalonamento da governança urbana na União Européia. Cadernos Metrópoles, São Paulo, v.12, n. 24, p. 535-564, jul/dez 2010.

[2] Holanda, Sérgio Buarque de. Raízes do Brasil. 26 ed. São Paulo: Companhia das Letras, 1995.

[3] Klink, Jeroen Johannes. Novas governanças para as áreas metropolitanas. $\mathrm{O}$ panorama internacional e as perspectivas para o diferenças de interesses, de significação e socioeconômicas.

Ao se demonstrar o caso específico da Região Metropolitana do Vale do Paraíba e Litoral Norte ficaram nítidas essas diferenças. Para tanto, foram demonstrados dados e mapas dessa região, com indicadores de PIB, área urbanizada e densidade demográfica; visando demonstrar quantitativamente estas disparidades entre os entes federados que compõem uma mesma Região Metropolitana.

Os instrumentos de planejamento e gestão dados pelas legislações traçam um caminho no qual estes entes federados, tão distintos entre si em vários aspectos, sejam tratados como iguais. Dando o mesmo ferramental para realidades e intenções de ações distintas. Este fato acaba por reafirmar e atenuar estas diferenças. Considera-se que a cooperação entre os pares, possibilitando instrumentos de gestão cooperativos dos entes federados análogos seja um caminho para uma efetiva governança interfederativa.

caso brasileiro.

[4] Lefebvre, Henri. A produção do espaço. 4 ed. Tradução: Doralice Barros Pereira e Sérgio Martins. Paris: Éditions Anthropos, 2006.

[5] Santos, Milton. Por uma economia política da cidade. São Paulo: Hucitec, 1994.

[6] Souza, Jessé. (Não) Reconhecimento e subcidadania, ou o que é "ser gente"? Lua Nova, n. 59, p. 51-74, 2003.

[7] Steinberger, Marília (org.). Território, Estado e Políticas Públicas Espaciais. Brasília : Libri Editorial, 2013 


\section{Bapítulo 11}

\section{MOBILIDADE E RESPONSABILIDADE SOCIAL: UMA ANÁLISE SOB A PERSPECTIVA DO DESENVOLVIMENTO ORIENTADO PELO TRANSPORTE COMO INDUTOR DE EQUIDADE E COESÃO URBANA}

\section{André Luiz Bezerra da Silva}

Resumo:A mobilidade, que durante muito tempo foi tratada por um viés numéricoquantitativo, passa, nos últimos anos, a ser um tema de investigação privilegiado também no campo das chamadas ciências sociais. Amplia-se assim as possibilidades de aplicação desse conceito no seio de políticas urbanas atuais, a partir do estreitamento de relações com conceitos como responsabilidade social, equidade e coesão urbana. No Rio de Janeiro, as recentes políticas de mobilidade e transporte público, apesar de apresentarem-se ainda como não fazendo parte de um planejamento mais amplo e sistêmico, podem revelar boas oportunidades para a realização de projetos e ações voltados para as áreas menos privilegiadas da cidade, amenizando um quadro histórico de desigualdade sócio-espacial, atribuindo um outro e mais amplo papel para os sistemas de transportes públicos.

Palavras-chave: mobilidade, equidade, coesão. 


\section{INTRODUÇÃO}

Este artigo é parte de uma pesquisa realizada junto ao Laboratório Redes Urbanas do Instituto de Pesquisa e Planejamento Urbano e Regional da Universidade Federal do Rio de Janeiro (IPPUR-UFRJ) e ao Centro de Estudos de Geografia e Ordenamento do Território da Universidade do Porto (CEGOT-UPORTO).

O objetivo principal é refletir acerca das recentes políticas de transportes públicos no Rio de Janeiro, e como estas poderiam contribuir, a partir de um aproveitamento sistemático e planejado do entorno dos equipamentos de interface ${ }^{53}$, para 0 desenvolvimento de ações afirmativas ${ }^{54} \mathrm{em}$ algumas áreas urbanas da cidade, ajudando na construção de um quadro de melhor equidade social e coesão urbana.

A discussão é feita com base nas ideias e concepções a partir das quais a mobilidade e as políticas de desenvolvimento orientado pelo transporte vêm sendo compreendidas a partir sobretudo do final do século XX, revelando o que se considera como uma essência multidisciplinar desses conceitos. A mobilidade, que durante muito tempo foi tratada por um viés numérico-quantitativo, passa, nos últimos anos, a ser um tema de investigação privilegiado também no campo das chamadas ciências sociais, ampliando assim as possibilidades de aplicação desse conceito no seio de políticas urbanas atuais. A partir de novas interpretações dadas pelas ciências sociais, a ideia de mobilidade é significativamente ampliada, estreitando sua relação com conceitos como responsabilidade social, equidade e coesão.

Sob esta perspectiva, o artigo foi dividido em três momentos. Um primeiro momento consiste numa discussão teórico-conceitual, abordando as novas formas de pensar e trabalhar a ideia de mobilidade, e por

\footnotetext{
53 Equipamentos que proporcionam uma comunicação física e direta entre os sistemas de transporte e outros sistemas urbanos, cujo entorno, num raio aproximado de $1 / 4$ de milha (450 a 500 metros), recebe atenção e tratamento especial: estações metroferroviárias, terminais rodoviários e terminais multimodais.

54 São medidas especiais tomadas e/ou coordenadas pelo poder público, espontânea ou compulsoriamente, com o objetivo de eliminar desigualdades historicamente acumuladas, garantindo a igualdade de oportunidades e tratamento, bem como de compensar perdas provocadas pela discriminação e marginalização sócio-espacial, decorrentes de motivos diversos. Portanto, visam combater os efeitos acumulados em virtude das discriminações e negligências ocorridas no passado.
}

extensão, das políticas de transporte público, com a inclusão agora de conceitos como responsabilidade social, equidade e coesão urbana, prática esta presente em vários países nas duas últimas décadas. Num segundo momento tenta-se estabelecer uma reflexão sobre os limites e possibilidades das recentes políticas de mobilidade e transporte no Rio de Janeiro, destacando a implantação dos Sistemas de Ônibus Articulados. O terceiro momento reserva-se à uma reflexão sobre possíveis ações e encaminhamentos para os setores público e privado, no que tange às políticas de transporte no Rio de Janeiro, e a importância que essa visão renovada da mobilidade e dos transportes pode ter para uma diminuição da desigualdade sócio-espacial na cidade.

O procedimento metodológico da pesquisa envolve a combinação de revisão conceitual da literatura sobre o tema, com estudos de campo e levantamento e análise de dados secundários, junto à órgãos, institutos e empresas ligados à temática de estudo.

Ressalta-se que este artigo, assim como a própria pesquisa, não ambicionam discutir a criação de um método ou modelo acabado para aplicação em planejamento urbano e políticas de transportes públicos, buscando mais conduzir uma reflexão sobre possibilidades de atuação dos transportes públicos na realização de algumas ações afirmativas de caráter mais amplo na cidade, a partir de uma compreensão contemporânea do conceito de mobilidade.

\section{O CONCEITO DE MOBILIDADE NO LIMIAR DO SÉCULO XXI: NOVAS ABRANGÊNCIAS E POSSIBILIDADES}

A discussão acerca da ideia de mobilidade um termo que pode ter mais de um significado, vem quase sempre relacionada apenas à conceitos como circulação, deslocamento ou trânsito, comumente tratados pela engenharia de transporte. Estudos e pesquisas recentes, sobretudo em áreas como Sociologia, Geografia, Direito, Arquitetura e Planejamento Urbano, vêm alargando o rol de possibilidades para se discutir essa temática, assegurando e difundindo o que se poderia chamar de um verdadeiro caráter multidisciplinar do conceito de mobilidade. 
Durante muito tempo os termos mobilidade e acessibilidade ${ }^{55}$ foram tratados sem nenhuma distinção, sendo entendidos como tendo o mesmo significado, o que é considerado um grande equívoco atualmente, pois embora ambos conceitos guardem estreitas relações e façam parte de um mesmo debate sobre circulação, dizem respeito à objetos diferentes.

Neste sentido, Vasconcellos (2001) sinaliza que a ideia de mobilidade se refere sobretudo às pessoas e não aos lugares, sendo reconhecida como uma habilidade humana de movimentar-se em decorrência de condições físicas, culturais, sociais e econômicas individuais, algo que foi durante muito tempo negligenciado e/ou desconsiderado pela engenharia de transportes, cujas ações e projetos fundamentavam-se basicamente em instrumentos matemáticos e estatísticos, por sinais de grande e fundamental importância, mas de pouca flexibilidade.

Kleiman (2011) defende que o conceito de mobilidade é mais amplo e complexo que o ato de deslocar-se no espaço físico, sendo antes de tudo uma condição de participação no mundo urbano e na vida social, uma capacidade de interagir em diferentes âmbitos sociais, mas que para efetivar-se precisa de um conjunto de fatores, como entre outros o nível de renda, a existência de modais de transporte coletivos e particulares e sua acessibilidade segundo o nível de renda, de modo que podem existir deslocamentos sem mobilidade. Para o autor, a mobilidade pode ser atribuída como um recurso social importante e integrante da sociedade, isto é, diretamente relacionado ao deslocamento de pessoas entre as diferentes hierarquias sócio-espaciais. Acredita-se hoje que os fatores principais que vão interferir na mobilidade são a renda, ocupação laboral, gênero, idade e o tipo de modal de transporte disponível, diferenciando, assim, as condições de mobilidade de cada grupo social ou pessoa (KLEIMAN, op cit.).

Balbim (2016) nos diz que o uso do termo mobilidade nas ciências em geral é algo

\footnotetext{
${ }^{55}$ Capacidade que um lugar tem de ser alcançado a partir de outros lugares com diferentes localizações geográficas e configurações sociais. Em outras palavras, a acessibilidade seria a qualidade de deslocar-se de um ponto ou de uma área sem ou com redução de barreiras na comunicação dos componentes de um sistema espacial (CASTIELLO; SCIPPACEROLA, 1998, apud KLEIMAN, 2011)
}

recente, e seu surgimento nessas áreas não aconteceu em substituição a nenhum dos demais termos já tratados desde longa data, mas vai além destes. Segundo o autor:

Deve-se ter claro, entretanto, que a noção de mobilidade supera a ideia de deslocamento físico, pois traz para a análise suas causas e consequências - ou seja, a mobilidade não se resume a uma ação. Em vez de separar o ato de deslocamento dos diversos comportamentos individuais e de grupo presentes tanto no cotidiano quanto no tempo histórico -, o conceito de mobilidade tenta integrar a ação de deslocar, quer seja uma ação física, virtual ou simbólica, às condições e às posições dos indivíduos e da sociedade (BALBIM, op. cit.).

Reconhecendo-se o fato de que a mobilidade esteja ligada à fatores como motivação pessoal, limitação financeira, imposições físicas, desejos, dentre outros, acredita-se também que esses fatores estão estreitamente ligados às diversas possibilidades que a sociedade apresenta, assim como também em razão dos lugares onde tais possibilidades estão ou não presentes. Isso amplia, dentro da discussão sobre mobilidade, a importância de fatores como a organização do espaço, as condições sócio-econômicas, culturais, políticas, o contexto simbólico, as características de acessibilidade e o desenvolvimento científico e tecnológico (BALBIM, op. cit.).

Tem-se assim que pensar em mobilidade, no campo exclusivo das ciências sociais, seja, antes de tudo, pensar para além da otimização dos movimentos em si, buscando o reconhecimento mesmo de uma condição humana, um direito, uma forma de inserção social, uma ação e uma condição das pessoas e dos lugares, que facilite e permita uma melhor participação no mundo do trabalho, na vida social e cultural, no debate político, na busca do conhecimento, na descoberta do possível, no pensar sobre a cidade e sua condição nela, na capacidade de conhecer e transitar por diferentes concepções sociais e culturais.

A partir desse entendimento, a mobilidade vem ganhando espaço como elemento de grande importância para as políticas públicas urbanas. Ela mesma, a mobilidade, torna-se um elemento catalisador de diversas e variadas ações e projetos. Relativiza um pouco a importância de objetos fixos e estanques, valorizando os movimentos 
enquanto produtores de interações de toda ordem e subjetividade. Não menos importante é a possibilidade que tem de se pensar maneiras de amenizar esquemas de segregação socioespacial. Tal concepção da mobilidade, pode permitir a adaptação de políticas públicas à diversas necessidades e contextos, aproveitando-se estruturas territoriais existentes ou a serem instaladas.

Para Balbim (op. cit.) caracteriza-se assim um momento no qual passamos de uma mobilidade fordiana, na qual a maior parcela dos deslocamentos acontecia em frações de tempo claramente definidas na jornada de trabalho, para um modelo mais flexível, no qual diversos deslocamentos seguem ritmos, objetivos, desejos, sonhos, horários e modos específicos. Segundo o autor, ampliam-se assim as trilhas espaço-temporais onde vamos escrevendo os roteiros ao longo de nossas vidas, os "caminhos empregados", de objetos e ações associados, dos lugares vividos, efetuando-se diferentes aptidões individuais para a mobilidade, característica do ser humano, sobretudo em nossa contemporaneidade.

Corroborando esse raciocínio, Barbosa (2016) diz que o debate crítico e propositivo sobre a mobilidade nas condições atuais de nossas cidades não deve ser posto exclusivamente no âmbito do econômico e do técnico, embora esses fatores sejam relevantes no cenário urbano contemporâneo. Segundo diz o autor, se faz necessário incorporar a dimensão política ao debate sobre a mobilidade.

Isso faz com que a mobilidade esteja ligada ao próprio processo de reprodução do território e suas relações, com todas as suas possibilidades e limites. Diante de situações de grande desigualdade $e$ inequidade urbanas vividas, sobretudo no Brasil, a discussão atual sobre mobilidade não pode ser abordada, no que tange principalmente aos seus objetivos, sem uma correlação direta com os conceitos de responsabilidade social, equidade e coesão, com implicações diretas nas políticas de desenvolvimento orientado pelo transporte.
3. RESPONSABILIDADE SOCIAL NAS POLÍTICAS DE DESENVOLVIMENTO ORIENTADO PELO TRANSPORTE: EQUIDADE E COESÃO COMO FOCO CENTRAL DAS AÇÕES

As primeiras manifestações sobre o tema da responsabilidade social surgiram no início do século $X X$, mas essas propostas iniciais não receberam apoio, pois foram consideradas de cunho socialista, sendo só a partir da década de 1950, nos Estados Unidos, que o tema recebeu atenção e ganhou espaço. $\mathrm{Na}$ década de 1970 começaram a surgir associações de profissionais interessados em estudar o tema, e somente a partir daí a responsabilidade social deixou de ser uma simples curiosidade e se transformou em um novo campo de estudo, ligado exclusivamente ao setor empresarial. No Brasil, embora o tema seja debatido desde a década de 1960, não chegou a fazer parte da agenda empresarial, vindo ganhar maior destaque somente a partir da segunda metade da década de 1990, por meio de publicações, experiências, programas e eventos para os interessados no tema.

Alguns estudos revelam que não há um consenso sobre o conceito de responsabilidade social, e que, por conseguinte, ele pode ser considerado em construção. Numa concepção mais geral, a responsabilidade social é compreendida como uma atitude e prática das empresas, que, de forma voluntária, adotam posturas, comportamentos e ações que promovam o bem-estar dos seus públicos interno e externo. Para Ashley (2003), responsabilidade social é toda e qualquer ação que possa contribuir para a melhoria da qualidade de vida, envolvendo muitas vezes medidas que trazem cultura e boas condições para a sociedade, sem ser, contudo, considerado como algo filantrópico ou assistencialista. Com o passar do tempo, tal concepção originou algumas variantes ou nuances, como Responsabilidade Social Corporativa, Responsabilidade Social Empresarial e Responsabilidade Social Ambiental.

Para Ashley (op. cit.), o mundo empresarial vê na responsabilidade social uma nova estratégia para aumentar seu lucro, melhorar sua imagem e visibilidade, potencializar seu desenvolvimento e gerar vantagem competitiva nos negócios. Essa tendência, segundo o autor, decorre da maior conscientização do consumidor e consequente procura por produtos, ideias e 
práticas que gerem melhoria para o meio ambiente e a comunidade, valorizando aspectos éticos.

No contexto contemporâneo, marcado por uma economia globalizada e aberta, pelo menos até certo ponto, e em certos lugares, seguido sobretudo a partir da década de 1990, emerge um certo ativismo social, onde palavras como cidadania e cooperação denunciavam um apelo por outras formas de organização e ações e projetos urbanos. O conceito de responsabilidade social torna-se assim mais amadurecido e abrangente, passando a incorporar também, de forma mais efetiva, o campo das políticas públicas, exigindo do próprio poder público uma postura diferenciada em relação à sociedade, onde o ganho exclusivamente pautado no econômico cede lugar a uma dimensão mais sistêmica que inclui uma incorporação do social e do ambiental. Isso, de certa forma, leva à produção de discursos que valorizam as práticas responsáveis, o capital social e a validação pública.

Ainda que dirigida por uma ótica capitalista, reconhece-se aqui que essa visão mais expandida da ideia de responsabilidade social, alcançando o campo da esfera pública, permite um olhar diferenciado sobre algumas políticas urbanas, influenciando num repensar de projetos e ações, como as políticas de Desenvolvimento Orientado pelo Transporte (DOT), que passam a serem entendidas e compreendidas nas proximidades de sua totalidade, a partir de um caráter mais interrelacional e uma ótica mais ampla, capazes, assim, de participarem mais ativamente na busca de um equilíbrio na relação de forças entre as áreas econômica e social.

Embora os princípios que norteiem as políticas de DOT sejam bem mais antigos ${ }^{56}$, é sobretudo a partir da década de 1990 que se constitui uma literatura voltada exclusivamente para essa temática. Fernandes (2011) afirma que com base na literatura disponível, a definição do DOT ainda não se apresenta consensual, assumindo vários contornos dentre os autores que tratam do assunto. Para o autor, o fato de não existir uma definição claramente elucidativa sobre

\footnotetext{
${ }^{56}$ Alguns autores referem a sua origem associada ao desenvolvimento de bairros de Nova lorque ao longo das linhas de caminho de ferro elevadas, outros recuam mais no tempo e admitem a gênese do DOT na localidade de Ur associado ao transporte fluvial (CARLTON, 2009, apud FERNANDES, 2011)
}

esse conceito acaba gerando diversas interpretações e adaptações sobre o mesmo.

A definição apresentada por Calthorpe (1993) é comumente considerada como a mais aceite dentre os estudiosos do tema. Para o autor, o DOT é uma área mista de elevada densidade residencial, comercial e de serviços, cujo núcleo, verticalmente integrado e no qual existe um equipamento de interface, é facilmente acessível a partir das áreas urbanas próximas (NELSON, 2001, apud FERNANDES, op. cit).

Para o Transit Cooperative Research Program (TCRP) o DOT consiste em parcerias para projetos específicos entre a iniciativa privada e a pública, com um padrão de ocupação denso e diversificado em termos do uso do solo, pontual e impulsionado pela valorização imobiliária em uma dada localidade, comumente relacionado aos nós da infraestrutura de transporte público, que pode, em alguns casos, se traduzir em mais desenvolvimento para algumas áreas (TCRP, 2002, apud NETO, 2011). Jacobson e Forsyth (2008, apud NETO, op. cit.) definem o DOT como uma estratégia para integração dos investimentos em transporte público e boas práticas de uso do solo, no sentido de se criar ambientes urbanos acessíveis e diversificados em termos de formas e uso, tanto em áreas centrais como em parcelamentos periféricos. Neto (op. cit.) assevera que o DOT consiste basicamente em estratégias de planejamento e de ações relativas ao desenho urbano $e$ de planejamento de transportes tratadas de forma integrada, realizadas por meio de políticas ou de instrumentos urbanísticos.

Os estudos de Fernandes (2011) ressaltam que o DOT pode ser promotor de diversas vantagens, como: mobilidade, estilo de vida, econômica/ambiental e dinâmicas urbanas. Também são apontadas algumas limitações nos projetos, como: desenho inapropriado de algumas redes, preocupações e temores das comunidades locais, desinteresse dos investidores e dificuldades na obtenção de financiamentos. Lembra o autor que essas vantagens e limitações não podem ser consideradas isoladamente, tampouco se resumirem apenas à esses aspectos. A relação entre essas vantagens e limitações pode ser resumida, sob o ponto de vista econômico, na relação custo-benefício, sendo o sucesso ou insucesso do DOT comumente medido pela maior ou menor preponderância dos benefícios obtidos com sua implantação, 
relativamente aos custos associados ao processo

Não obstante essas afirmações, acredita-se, fazendo coro às colocações de Fernandes (op. cit.), que o sucesso e importância do DOT não podem ser avaliados apenas pelo viés custo-benefício, ainda que reconhecendo a importância deste aspecto, mas também a partir de outras dimensões e questões, capazes de ampliar a globalidade dos efeitos produzidos.

Neste sentido é que defende-se aqui a necessidade de uma integração mais profunda entre as políticas de DOT e os princípios de equidade social e coesão territorial, criando-se assim oportunidades de se atribuir ao transporte público coletivo uma atuação mais plena no território, superando as abordagens voltadas majoritariamente para a ofertas de mais infraestruturas.

Eqüidade social é entendida como um princípio pelo qual o poder público deve prover acesso justo e igual para a superação das necessidades sociais básicas (DAVEY e DEVAS, 1996), como acesso ao emprego, cultura, lazer, saúde e condições de vida razoáveis, indiferente de renda ou localização, evitando assim dar preferências para grupos sociais específicos, a partir de circunstâncias tais como diferenças de localização territorial, etnia, religião, status e poder etc. Harvey (1973) considera que eqüidade resulta de interações entre processos sociais e forma espacial. Conseqüentemente, desigualdades existem nas condições de vida porque existem desigualdades espaciais ou territoriais (MASSEY, 1984). A equidade deve ser compreendida assim como um conceito primário na distribuição de benefícios de urbanização para todos membros de uma sociedade, um conceito antes de tudo político, indispensável em políticas urbanas que almejem cidades melhores para se viver.

Como um desdobramento possível a partir do princípio de equidade, e visando mesmo uma integração e melhor realização desta, a noção de coesão territorial pauta-se na importância do território no seio das políticas, com o intuito generalizado de alcançar o desenvolvimento territorial mais equilibrado, ou seja, um desenvolvimento social e econômico mais equitativo, valorizando a sua diversidade e complementaridades, possibilitando à população aproveitar melhor as características existentes em cada território.
Segundo Santinha (2014), a ideia de coesão visa um aproveitamento da diversidade dos territórios, ou seja, considera as potencialidades e as fragilidades territoriais, o que consequentemente se traduz na análise das capacidades (bens, equipamentos, infraestruturas, recursos) existentes para formular políticas territorialmente diversificadas. Segundo o autor, importantes ideias ganham destaque, como: ultrapassar as diferenças de densidade, evitando concentrações excessivas de crescimento e facilitando 0 acesso aos benefícios proporcionados pelas aglomerações existentes em todos os territórios; melhorar o acesso, através de uma melhor conectividade, aos serviços de interesse geral, de forma social e espacialmente equitativa; eliminar divisões, na medida em que os problemas de conectividade e de concentração só podem ser eficazmente resolvidos com a estreita cooperação entre todos os níveis de intervenientes.

Segundo Santinha (op. cit.), esta ideia de articular, integrar e territorializar as políticas públicas, incorporando a dimensão territorial nas políticas setoriais, articulando estas com as políticas de base territorial ${ }^{57}$, contribui para uma maior sinergia entre diferentes políticas e para a maximização dos seus impactos territoriais, amenizando o fato de as decisões políticas serem tomadas essencialmente de um ponto de vista setorial e de forma desarticulada com as políticas territoriais. Ressalta o autor, contudo, que este propósito só é viável a partir de uma articulação mais eficiente entre diferentes níveis de atores/entidades/administração, decisiva para a formulação de políticas e construção de estratégias coletivas territoriais

Trazendo essas ideias de equidade e coesão para o interior das políticas de transportes públicos, a nossa percepção do transporte ultrapassa o entendimento que o vê somente como uma questão técnica de engenharia, evoluindo para uma questão e discussão social, econômica, cultural e política, como parte de uma problemática urbana mais ampla, podendo inclusive ser pensado como elemento capaz de minimizar esquemas de desigualdade sócio-espacial na cidade,

57 Políticas que procuram abranger toda a diversidade e potencialidades do território, priorizando ações e projetos multissetoriais, objetivando um melhor e mais efetivo aproveitamento dos recursos, equipamentos e possibilidades existentes no território. 
contribuindo para um melhor quadro de equidade e coesão urbana.

Nos últimos vinte anos inúmeras são as experiências e projetos pelo mundo e pelo Brasil que vêm buscando orientar políticas de transportes públicos com base nos princípios de equidade e coesão urbana, a partir de um aproveitamento sistemático dos equipamentos de interface, sem desconsiderar, contudo, aspectos fundamentais de engenharia e operação técnica. Ações e projetos exitosos podem ser encontrados em cidades como Madrid, Porto, Berlim, Toronto, Cleveland, Curitiba, São Paulo e Brasília. Apesar de realidades sociais distintas, essas cidades têm em comum o fato de virem desenvolvendo nessas duas primeiras décadas do século XXI projetos de transportes públicos cujo objetivo principal não é só o deslocamento físico em si, mas a possibilidade de produzirem espaços urbanos mais equânimes no tocante ao acesso à serviços, equipamentos, atividades, moradias, conhecimento, cultura, lazer etc.

No Rio de Janeiro essa tendência ainda parece um pouco ausente, embora seus recentes projetos de transporte público, como a implantação dos Sistemas de $\mathrm{BRT}^{58}$, sobretudo a Transcarioca e a TransBrasil, apontem algumas possibilidades de uma relação mais estreita com a ideia de responsabilidade social e os princípios de equidade e coesão urbana, revelando assim uma oportunidade histórica de se equipar com atividades e serviços áreas menos privilegiadas da cidade, com novas oportunidades para se produzir um espaço urbano menos desigual.

\section{LIMITES E POSSIBILIDADES NA ATUAL POLITICA DE TRANSPORTE PÚBLICO NO RIO DE JANEIRO}

Nos últimos anos as discussões sobre as políticas de mobilidade e transporte público no Rio de Janeiro vêm ultrapassando cada vez mais a ideia de que estas devam estar centrada apenas na otimização do

\footnotetext{
58 A sigla vem do inglês Bus Rapid Transit (Trânsito Rápido por Ônibus). Na prática, representa um transporte articulado de média capacidade que trafega em corredor exclusivo e, por isso, é uma alternativa mais rápida de viagem para os passageiros. Este modelo de circulação existe em cerca de 140 países, e no Rio de Janeiro é administrado por um grupo de empresas privadas de transporte e passageiros, reunidas em consórcio.
}

deslocamento físico, ainda que reconhecendo a importância deste, buscando também formas de (re)criar novas relações cotidianas entre pessoas e lugares, com uma melhor distribuição de serviços, equipamentos e atividades pela cidade.

Embora alguns processos recentes já sinalizem possíveis mudanças de pensamento, verifica-se que ainda não há um aproveitamento e um uso planejado do entorno dos equipamentos de interface do sistema de transporte público coletivo, deixando transparecer um certo "atraso" em relação à outras metrópoles nacionais e internacionais, ainda que em algumas dessas também inexista legislação específica para o aproveitamento do espaço envolvente desses equipamentos, mas, contando-se, em alguns casos, com o incentivo à participação e envolvimento de vários atores urbanos, relativizando assim a predominância do interesse unicamente do capital privado.

O BRT TransCarioca (fig. $n^{\circ}$ 1), em funcionamento desde 2014, é o primeiro corredor de transporte público que conecta transversalmente a cidade. O corredor cruza áreas densas e bem consolidadas, com um déficit histórico não apenas de transporte público de qualidade, mas também de equipamentos e serviços urbanos. Atende 27 bairros das zonas norte e oeste do município, ligando o Terminal da Alvorada (Barra da Tijuca) ao Aeroporto Internacional Tom Jobim (Ilha do Governador). Ele conta com 47 estações e $39 \mathrm{~km}$ de vias segregadas, integrando-se aos sistemas de trens metropolitanos e metrô, essenciais para o acesso à região central da cidade e a outras localidades dentro da Região Metropolitana, e ao BRT TransOeste, que realiza a conexão com o extremo oeste do município. Pela sua dimensão e abrangência, esse corredor, segundo o Instituto de Políticas de Transporte e Desenvolvimento (ITDP- Brasil) (2016), deve ser visto não somente como uma solução isolada de circulação para as áreas que atende, mas principalmente como um eixo indutor de desenvolvimento urbano capaz de contribuir para a consolidação de uma cidade mais justa e harmônica em termos sócioespaciais. 


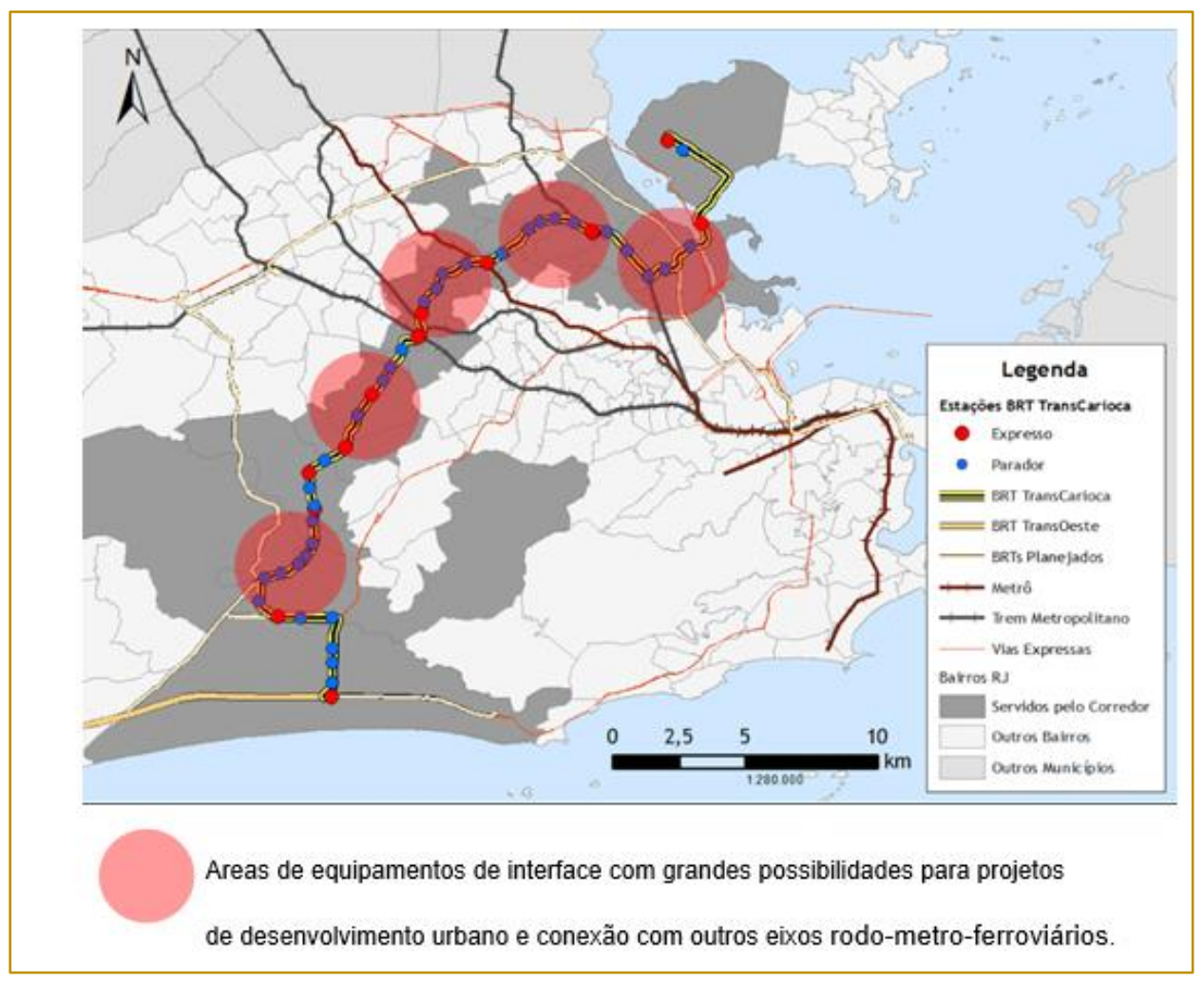

Fonte: ITDP - Brasil, 2016 (com marcações do autor).

Além do apelo do ITDP, vários outros órgãos e pesquisadores isolados, vêm discutindo e mostrando a necessidade de que as áreas do entorno dos equipamentos de interface desse corredor de BRT recebam um plano especial de desenvolvimento orientado ao transporte, estimulando a criação de bairros de uso misto (residencial e comercial). Cada vez mais alerta-se ao fato de que esse projeto de transporte tem de estar integrado a um planejamento urbano mais amplo, que distribua melhor as oportunidades da cidade e que diminua as necessidades de deslocamento, sob risco de se perder uma valiosa oportunidade de desenvolvimento urbano para a cidade.

Outro importante sistema de BRT que vem sendo implantado na cidade, a TransBrasil, conectado à Transcarioca (fig. no 2), vem revelando, através de estudos e levantamentos de campo, um enorme potencial de redefinição do eixo rodoviário sobre o qual se instalará, a Avenida Brasil, com $58 \mathrm{~km}$ de extensão e marcada hoje por imensas áreas urbanas degradas ou subutilizadas. O Sistema de BRT da Transbrasil vem como uma oportunidade histórica para a reestruturação de imensas áreas urbanas, sobretudo próximo aos seus equipamentos de interface, fazendo com que deixem de ser espaços somente de passagem, e se tornem espaços de trabalho, vivência, educação, inovação tecnológica, cultura e lazer. 


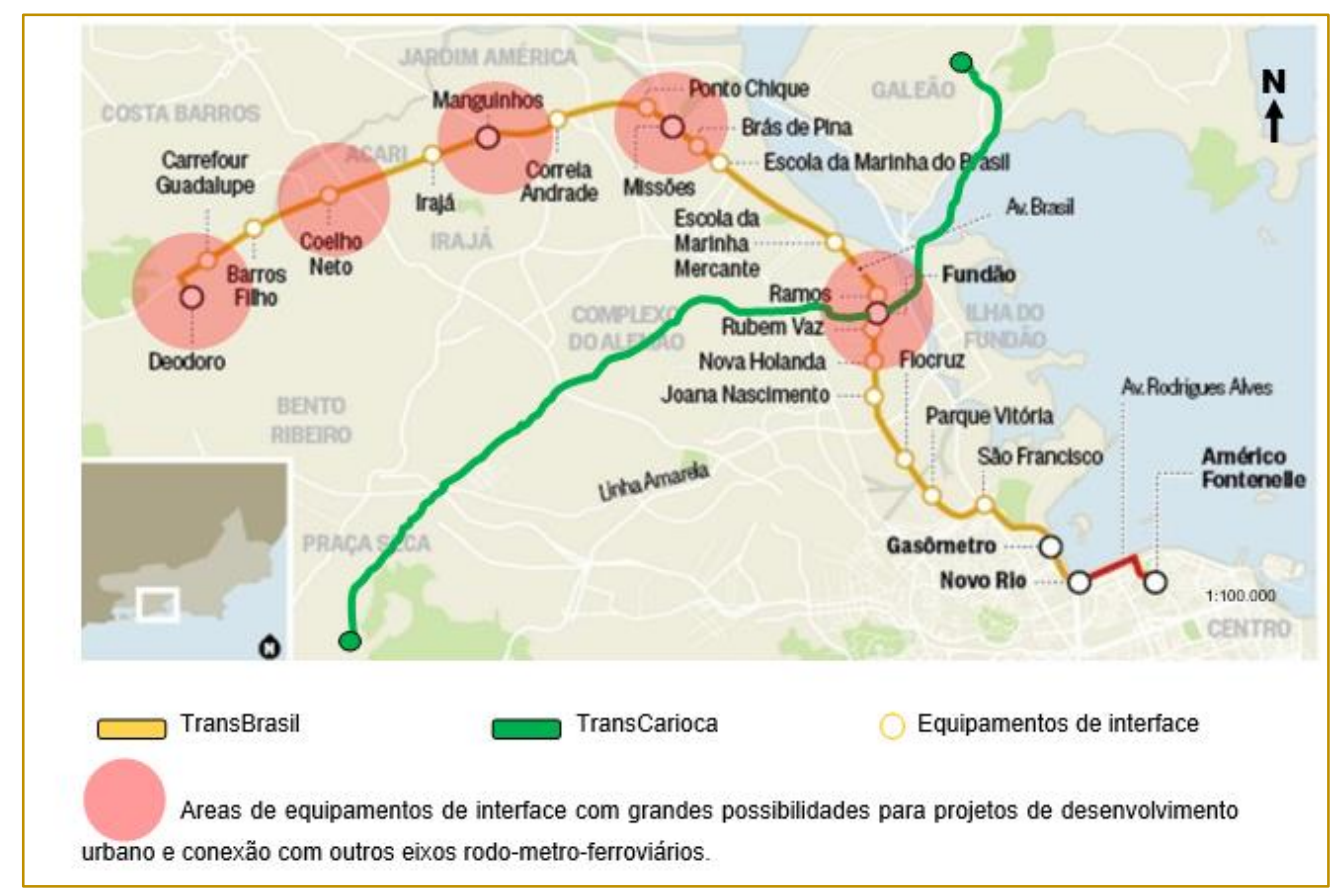

Fonte: Prefeitura Municipal do Rio de Janeiro - 2016 (com marcações do autor).

Através de um plano específico e uma intervenção controlada no entorno dos principais equipamentos de interface da TransBrasil, pensa-se, através das características físicas, sociais, culturais e econômicas existentes em cada área, que estes sejam capazes de oferecer condições para uma melhor interatividade de projetos, ações e atores, interligando e aproximando pessoas, serviços e equipamentos nessas áreas, abrindo possibilidades de amenização de um quadro de fraca equidade e coesão urbana

Conquanto não seja o único caminho possível para auxiliar no desenvolvimento de um pretenso quadro de melhor equidade e coesão urbana, dependendo inclusive de outras ações para sua eficácia, como segurança e renda, por exemplo, vale a pena considerar, e as experiências em outros contextos urbanos confirmam, as ações e projetos no entorno dos equipamentos de interface do sistema de transportes coletivos, como uma alternativa visando a valorização e dinamização de muitas áreas da cidade, sendo um instrumento fundamental e de imenso potencial, merecedor de tratamento e atenção especial.

Muito além de uma reordenação de formas e deslocamentos, está em jogo neste momento um futuro de novas e melhores oportunidades na cidade do Rio de Janeiro, futuro este que para ser melhor não pode prescindir da ideia de mobilidade em um novo paradigma, abordando a relação dos deslocamentos das pessoas com o planejamento das cidades para um desenvolvimento mais harmônico e justo, de modo a propiciar o acesso universal da população às oportunidades oferecidas pela cidade.

Com a implantação dos Sistemas de BRT Transcarioca e TransBrasil, seguidos de uma necessária otimização de seus aspectos operacionais $^{59}$, cria-se, acredita-se, novas possibilidades de relações dos transportes públicos com a cidade, relações que não apenas de trabalho, consumo ou lucratividade, mas também de incentivar misturas, expectativas, sonhos, desejos, esperanças, diminuindo esquemas de segregação e disparidades sócio-espaciais. Esta característica nunca esteve presente nas políticas de transporte público no Rio de Janeiro, marcadas comumente por suas funções econômicas e objetivos de lucro, impedindo um papel dos transportes coletivos enquanto instrumento produtor de espaços

\footnotetext{
59 Integração físico-tarifária com outros sistemas de transporte, intervalo entre os veículos, segurança, conforto e informação junto aos equipamentos do sistema de transporte.
} 
equânimes, dotados de boa urbanidade e não tão desiguais. Há uma importante lacuna a ser preenchida quanto ao papel dos transportes coletivos e seus equipamentos de interface no Rio de Janeiro, que inclui não apenas a otimização e eficiência dos deslocamentos, mas principalmente a vinculação desses equipamentos à produção de espaços capazes de propiciarem mudanças futuras e novas oportunidades na vida de muitas pessoas, e nesse aspecto os sistemas de BRT precisam ser repensados em seus efeitos sobre a cidade.

\section{POSSÍVEIS AÇÕES PARA OS PODERES PÚBLICO E PRIVADO}

Na questão que aqui vem sendo pensada, as ações e projetos no entorno dos equipamentos de interface do sistema de transporte coletivo no Rio de Janeiro, o que está em jogo é principalmente a possibilidade de se criar condições para que grupos menos favorecidos possam ter novas oportunidades e viver melhor, numa cidade menos desigual. Isto implica uma redefinição das políticas públicas $^{60}$ e das prioridades de investimentos, em função da realidade local e da manifestação da população, o que confere uma certa legitimidade necessária para inverter a ordem da destinação dos recursos, das obras e serviços públicos para atender os reais interesses da população. Por isso, acredita-se que paralelamente às novas relações de gestão urbana, marcadas por uma forte intervenção do setor privado, o papel do poder público deve ser permanentemente reinventado, e não diminuído ou secundarizado, a fim de poder agir criando as oportunidades para reduzir tensões e desigualdades nos espaços partilhados das relações urbanas.

Entendendo o entorno dos equipamentos de interface como espaços capazes de reunirem atividades diversificadas e multifuncionais, as

\footnotetext{
${ }^{60}$ Diretrizes, princípios norteadores de ação do poder público, regras e procedimentos para as relações entre poder público e sociedade, mediações entre atores da sociedade e do Estado. São, nesse caso, políticas explicitadas, sistematizadas ou formuladas em documentos (leis, programas, linhas de financiamentos) que orientam ações que normalmente envolvem aplicações de recursos públicos. Nem sempre, porém, há compatibilidade entre as intervenções e declarações de vontade $e$ as ações desenvolvidas. Devem ser consideradas também as "não-ações", ou seja, as omissões, como formas de manifestação de políticas, pois representam opções e orientações dos que ocupam cargos (TEIXEIRA, 2002).
}

políticas e os projetos para essas áreas precisam ser caracterizados por objetivos definidos a priori, marcados por uma transparência do início ao fim e por um acompanhamento permanente, a fim de não se desvirtuarem seus objetivos e propostas centrais. Acredita-se, com isto, que o poder público deva ser o principal coordenador dessas ações.

A importância da coordenação central do poder púbico reside no fato de que as políticas e ações devem manter como foco principal a contribuição que podem oferecer na construção de um quadro de melhor equidade e coesão urbana, ainda que para isto dependam também de outros fatores, procurando evitar a predominância de objetivos estreitos e limitados. Essa atuação central do poder público não impede que relações sejam estabelecidas envolvendo poder público e privado, diferentes setores privados entre si e também diferenciados setores e níveis do poder público (local, municipal, regional e nacional). Desenvolvendo e coordenando programas que impulsionem a renovação e a multifuncionalidade de áreas no entorno dos equipamentos de interface, com projetos de requalificação que permitam melhorar a qualidade do ambiente urbano e a integração de distintos espaços da cidade, tem o poder público uma boa oportunidade de promover e articular a integração de diferentes políticas setoriais, voltadas para áreas já ocupadas e mais desfavorecidas, principalmente aquelas já providas de infra-estrutura de transporte coletivo rodo-metro-ferroviário.

Para isto, torna-se importante e fundamental que as áreas no entorno ${ }^{61}$ de alguns equipamentos de interface tornem-se Áreas de Intervenção Especial e Controlada (AEIC), passíveis de aplicação, por parte do Estado, de alguns instrumentos de política urbana, instrumentos estes já previstos pelo Estatuto da Cidade $^{62}$, sobretudo aqueles de cunho jurídico e político, como: Instituição de zonas

\footnotetext{
${ }^{61}$ Tendo por base o que comumente é considerado nos estudos sobre DOT, sugere-se que esse entorno esteja delimitado inicialmente por um raio de $600 \mathrm{~m}$ a partir da boca dos equipamentos de interface.

62 Lei 10.257, de 10 de julho de 2001, que regulamenta o capítulo "Política Urbana" da Constituição Federal, detalhando e desenvolvendo os artigos 182 e 183. Seu objetivo é garantir o direito à cidade como um dos direitos fundamentais da pessoa humana, para que todos tenham acesso às oportunidades que a vida urbana oferece.
} 
especiais de interesse social ${ }^{63}$; Parcelamento, edificação ou utilização compulsórios ${ }^{64}$; Transferência do direito de construir ${ }^{65}$; Outorga onerosa do direito de construir e alteração de uso ${ }^{66}$; Direito de preempção ${ }^{67}$; e Operações urbanas consorciadas ${ }^{68}$.

Alerta-se para o fato de que a aplicação dos instrumentos acima sugeridos não busca defender uma lógica segundo a qual "tudo o que há de melhor na cidade deve ficar junto dos equipamentos de interface do sistema de transporte", mas sim favorecer um melhor e planejado aproveitamento das oportunidades que esses equipamentos possam oferecer para ações e projetos urbanos, visando a implementação de ações afirmativas, por meio de políticas de ordenamento territorial que tenham em vista a correção das distorções verificáveis no espaço urbano. Esta perspectiva ampara-se na ideia de que o futuro da intervenção nas cidades envolve

\footnotetext{
${ }^{63}$ São porções do território destinadas, prioritariamente, à recuperação urbanística, à regularização fundiária e produção de Habitações de Interesse Social ou do Mercado Popular, incluindo a recuperação de imóveis degradados, a provisão de equipamentos sociais e culturais, espaços públicos, serviços, atividades e comércio (Estatuto da Cidade).

64 Poderá o poder público, para área incluída no plano diretor, determinar o parcelamento, a edificação ou a utilização compulsórios do solo urbano não edificado, subutilizado ou não utilizado, devendo fixar as condições e os prazos para implementação da referida obrigação (Estatuto da Cidade).

65 Baseado no plano diretor, poderá o poder público autorizar o proprietário de imóvel urbano, privado ou público, a exercer em outro local, ou alienar, mediante escritura pública, o direito de construir previsto no plano diretor ou em legislação urbanística dele decorrente, quando o referido imóvel for considerado necessário para fins de implantação de equipamentos urbanos e comunitários (Estatuto da Cidade).

${ }^{66} \mathrm{O}$ poder público, pelo plano diretor, poderá fixar áreas nas quais o direito de construir poderá ser exercido acima do coeficiente de aproveitamento básico adotado, mediante contrapartida a ser prestada pelo beneficiário. O coeficiente de aproveitamento é a relação entre a área edificável e a área do terreno. O plano diretor poderá fixar coeficiente de aproveitamento básico único para toda a zona urbana ou diferenciado para áreas específicas dentro da zona urbana (Estatuto da Cidade).

67 direito de preempção confere ao Poder Público municipal preferência para aquisição de imóvel urbano objeto de alienação onerosa entre particulares. Será exercido sempre que o Poder Público necessitar de áreas para ordenamento e direcionamento da expansão urbana; implantação de equipamentos urbanos e comunitários; e criação de espaços públicos de lazer e áreas verdes (Estatuto da Cidade).

${ }^{68}$ Conjunto de intervenções e medidas coordenadas pelo Poder Público municipal, em áreas delimitadas, com a participação dos proprietários, moradores, usuários permanentes e investidores privados, com o objetivo de alcançar em uma área transformações urbanísticas estruturais, melhorias sociais e a valorização ambiental (Estatuto da Cidade).
}

centrar-se no aproveitamento das potencialidades dos equipamentos de transporte público, sobretudo na melhoria da sua articulação com outras ações e políticas setoriais. Isto porque acredita-se que quanto mais eficaz for a aplicação dos princípios da cooperação, da coordenação (entre políticas setoriais) e da subsidiariedade, mais facilmente os objetivos de equidade e coesão urbana poderão ser alcançados.

É necessário também que o poder público atente de forma permanente para que os processos no entorno dos equipamentos de interface não promovam uma expulsão da população vizinha para outras áreas da cidade. Para este fim um caminho possível seria a promoção de uma maior diversidade de usos, atividades e serviços voltados para o desenvolvimento urbano, sócio-cultural e econômico, o que, ainda que não promova uma integração social plena, possa possibilitar um usufruto por um número maior de pessoas.

Outro aspecto fundamental para a ação do poder público, mas que também pode ser executado pelo poder privado, é a promoção e divulgação - antes, durante e depois-, através de um sistema de comunicação social adequado, das vantagens, desafios e custos das ações e projetos, construindo assim um quadro de transparência, visando um maior de comprometimento social.

Desta maneira, acredita-se, o sistema de transporte coletivo assumiria uma posição mais central no que se pode chamar de uma reflexão urbana mais ampla, representando mais do que um somatório de equipamentos para o deslocamento urbano, mas, pelo contrário, como frisou Chamusca (2012), promovendo a construção de visões de um desenvolvimento urbano que traduza a definição e a partilha de objetivos e projetos comuns. Teria-se assim a possibilidade do reforço de uma dimensão social nas políticas de transporte coletivo, associando-as, no caso dos espaços urbanos, aos interesses de uma melhor equidade e coesão.

Essas ações aqui pensadas, ainda que não produzam num curto prazo os efeitos desejados (melhores condições de equidade e coesão urbana), revelam-se importantes, num primeiro momento, pois podem ajudar a recriar o sentido e o papel dos transportes coletivos na cidade, desenvolvendo um espírito de permanente coordenação entre a política de circulação e transporte e a política 
de uso do solo, até que ambas, num segundo momento, se tornem uma só, institucionalizada e promotora de comunicação entre os diversos atores urbanos, debatendo a forma como estes aspectos se articulam com os objetivos urbanos mais amplos.

\section{CONSIDERAÇÕES FINAIS}

No contexto recente, que vem sendo marcado pela implementação de alguns projetos de mobilidade e transporte público no Rio de Janeiro, coloca-se em perspectiva as áreas da cidade marcadas pela carência de serviços, espaços públicos e equipamentos urbanos, cujos grandes projetos de "revitalização", à exceção de algumas ações muito pontuais, tem relegado ao esquecimento.

Ainda que reconhecendo o fato de que a cidade não seja apropriada por todos em sua plenitude, é também reconhecida a necessidade e importância de que esses projetos mais recentes de mobilidade e transportes públicos no Rio de Janeiro, como os Sistemas de BRTs, incluam como fundamental a utilização planejada do entorno dos equipamentos de interface, enquanto uma ação específica e coordenada pelo poder público em parceria com o privado e a sociedade civil, permitindo o desenvolvimento orientado de atividades e serviços diversos, facultando que muitos possam se apropriar desses espaços e das benesses e vantagens que possam ali ser implementadas, criando laços de identificação e convivência entre grupos sociais diversos, propiciando assim uma urbanidade mais rica e ampla, sobretudo em áreas menos favorecidas.

O transporte coletivo seria assim o grande meio dessa experiência, pois viabilizaria o acesso de grandes áreas da cidade a esses espaços e desses espaços com toda a cidade, diminuindo o forte efeito divisor que sempre permeou seu papel - deslocar-se-ia

\section{REFERÊNCIAS}

[1] Ashley, P. A. Ética e responsabilidade social nos negócios. São Paulo: Saraiva, 2003.

[2] Balbim, Renato. Mobilidade: uma abordagem sistêmica. In: Cidade e movimento: mobilidades e interações no desenvolvimento urbano. Brasília : Ipea - ITDP, 2016. 326 p.

[3] Barbosa, Jorge Luiz. O significado da mobilidade na construção democrática da cidade. agora para se buscar o diferente, o coletivo, se complementar e se redescobrir, e não somente para se separar ou dividir. Essa busca e complementaçâo viabilizaria novas experiências, motivando e enriquecendo a reconstrução de ideias e sentidos e criando afetos, na construção da cidade mais equânime, coesa, plural e tolerante.

Há uma importante limitação a ser superada quando se fala de mobilidade e transporte público no Rio de Janeiro, superação esta que levaria o debate e as propostas para além da eficiência dos deslocamentos, vinculando esses conceitos à produção de espaços capazes de propiciarem não só o consumo e a alocação deste ou daquele grupo nesta ou naquela parte da cidade, mas que possibilitem mudanças e novos rumos à vida de muitas pessoas.

O modelo que trata a mobilidade e os sistemas de transportes coletivos separado das ideias de responsabilidade social, equidade e coesão, precisa ser superado, não precisamente por outro modelo, mas por uma prática constante de tentar identificar todas as reais possibilidades e questões que perpassam as políticas de transporte, em todos os seus níveis e aspectos.

Pensar a mobilidade e o transporte coletivo na contemporaneidade exige antes pensar a cidade que se quer ter, compreendendo seus desafios, necessidades e limites. Não se trata apenas de pensar o sistema de circulação e transporte vinculado a outras ações no território, pois isso já se faz desde muito tempo, mas sim de pensar como essas ações podem ajudar na construção de uma cidade mais justa e melhor para viver, com políticas concebidas para a concretização de um objetivo constitucional universalmente reconhecido - o da efetiva igualdade de oportunidades a que todos devem ter direito. Isso abre inúmeras possibilidades de ações e coloca a discussão sobre mobilidade e transporte num outro e mais elevado patamar da questão urbana.

In: Cidade e movimento: mobilidades e interações no desenvolvimento urbano. Brasília : Ipea - ITDP, 2016. 326 p.

[4] Calthorpe, Peter. The Next American Metropolis: ecology, communit and the american dream. London: Princenton Architecture press, 1993.

[5] Chamusca, Pedro Miguel Magalhães Nunes. Governança e regeneração urbana: entre a 
teoria e algumas práticas. 2012. 378 f. Tese (Doutorado em Geografia) - Faculdade de Letras da Universidade do Porto, Porto 2012.

[6] Davey, K ; Devas, N. Urban Government Finance. In Davey, K (ed.) Urban Management, the Challenge of Growth. Avebury: Aldershot, 1996.

[7] Fernandes, António Rui Gonçalves. Transit-Oriented Development - um ensaio metodológico para o Porto. Dissertação (Mestrado em Sistemas de Informação Geográfica e Ordenamento do Território) - Faculdade de Letras da Universidade do Porto, Portugal, 2011.

[8] Harvey, David. Social justice and the city. London: Edward Arnold and The Johns Hopkins University Press, 1973.

[9] Instituto de políticas de transporte e desenvolvimento (itdp). Papel do brt transcarioca na redução da desigualdade social e acesso à cidade do rio de janeiro. Brasil: itdp, 2016. Disponível em http://itdpbrasil.org.br/pesquisabrt/. Acessado em 27 abr2017.

[10] Kleiman, Mauro. Transportes e mobilidade e seu contexto na América Latina. Série Estudos e Debates (IPPUR-UFRJ), n 61, p. 1-10. 2011.

[11] Massey, D. Spatial Divisions of Labour: Social Structures and the Geography of Production. Basingstoke : Macmillan, 1984.
[12] Neto, Vicente Correia Lima. Desenvolvimento Orientado ao Transporte: o potencial de aplicação pela Companhia Brasileira de Trens Urbanos. IPEA, Boletim Regional, Urbano e Ambiental, no 5, junho de 2011.

[13] Oliveira, Chirles Virgínia A. de. O Discurso da Sustentabilidade e da Responsabilidade Social na Estratégia Corporativa: comunicação em rede, consumo e cidadania. Dissertação de mestrado. 155 p. (Mestrado em Comunicação e Práticas de Consumo). São Paulo: Escola Superior de Propaganda e Marketing, 2011.

[14] Santinha, Gonçalo. O princípio de coesão territorial enquanto novo paradigma de desenvolvimento na formulação de políticas públicas: (re)construindo ideias dominantes. In: Revista EURE (Santiago) vol.40, no 119, Santiago ene. 2014

[15] Teixeira, Elenaldo Celso. O Papel das Políticas Públicas no Desenvolvimento Local e na Transformação da Realidade. in: Políticas Públicas - O Papel das Políticas Públicas, 2002.

[16] Vasconcellos, Eduardo Alcântara.. Transporte Urbano, Espaço e Eqüidade: análise das políticas públicas. 3aed. São Paulo: Annablume, 2001. 


\section{Gapítulo 12}

\section{AS OCUPAÇÕES ESTUDANTIS NO MUNICÍPIO DE CURITIBA E SEGREGAÇÃO URBANA: A ESCOLA ENTRANDO EM CENA NA LUTA PELO DIREITO À CIDADE}

\section{Anna Paula Scherer Lino}

\section{Kauê Avanzi}

Resumo: $\mathrm{O}$ artigo a seguir pretende esboçar uma reflexão acerca das ocupações estudantis no Paraná à partir das experiência vividas por professores e estudantes dos Colégios Estaduais Alfredo Parodi e Rodolpho Zaninelli. Para tal, nos utilizamos da Teoria da Implicação (BAITZ, 2006, 2013) para chegar ao nível do cotidiano, buscando compreender o que havia de luta pelo direito à cidade que extravasava as pautas contra a reforma do Ensino Médio e a PEC do congelamento de gastos públicos. Foi possível perceber, à partir da mobilização estudantil, o quanto as precariedades da escola refletiam, no geral, uma miséria vivida nas periferias da cidade de Curitiba, expressas e refletidas na escola de maneira geral.

Palavras chave: Ocupações estudantis; Vida cotidiana; Teoria da implicação; Direito á cidade. 


\section{INTRODUÇÃO:}

Outubro a Novembro de 2016: um período que ficará marcado na história da educação brasileira. Em meio a um cenário de instabilidade política, ascensão conservadora e retrocessos dos direitos da classe trabalhadora no país de maneira geral, a resistência e luta inicia-se justamente de um grupo que muitos pensavam que estava "adormecido" e "enfraquecido": o movimento estudantil secundarista.

No referido ano, os estudantes paranaenses, mobilizados contra a proposição por parte do governo federal de uma reforma nas diretrizes do ensino médio e de uma proposta de emenda constitucional (PEC) que congela em 20 anos investimentos em saúde e educação, ocuparam 836 escolas, 13 universidades e 3 núcleos de educação do estado do Paraná, iniciando um movimento que, em pouco tempo, se expandiu por todo o Brasil. Não houve anteriormente, na história da educação pública do Brasil, uma organização e mobilização tão grande quanto a que ocorreu durante estes dias.

As mobilizações iniciaram-se nas escolas de periferia localizadas na cidade e na região metropolitana de Curitiba, inspiradas nas manifestações ocorridas no Estado de São Paulo no ano de 2015, onde estudantes promoveram, como forma de protesto, a ocupação de instituições de ensino em que estudavam, visando barrar o fechamento de escolas imposto pelo então governador Geraldo Alckmin ${ }^{69}$. Este mesmo processo sucedeu-se no Chile, dez anos antes, em 2006, onde estudantes apelidados de pinguins - por conta do uniforme composto por terno e gravata - protagonizaram as maiores marchas populares desde o fim da ditadura do general Augusto Pinochet (19731990) em busca do acesso gratuito e público à educação e ao passe livre no transporte. Não obstante, no ano de 2011, os protestos se repetiram e mais de 700 escolas foram ocupadas no país.

Tendo em vista o cotidiano e a organização dos secundaristas no dia a dia das ocupações, que se apresentaram para

69 Sobre a relação entre as ocupações de escolas públicas e a especulação imobiliária no município de São Paulo ver: GIROTTO, Eduardo Donizeti; PASSOS, Felipe Garcia; CAMPOS, Larissa; OLIVEIRA, João VictosPavesi. A Geografia da Reorganização Escolar: Uma Análise Espacial à Partir da Cidade de São Paulo. Disponível em: https://periodicos.sbu.unicamp.br/ojs/index.php/etd/articl e/view/8647805/15187 além da reivindicação contra as proposições do Estado, a obstinação e antagonismo dos estudantes revelam uma busca por melhores oportunidades de vida, um descontentamento geral com a atual estrutura da educação e da sociedade brasileira, principalmente com o formato tradicional do sistema educacional vigente cujos estudantes estão e são submetidos diariamente. Tais fundamentos opressivos repetem-se quando o mundo do trabalho, a cidade, e a vida fora da escola reproduzem a segregação espacial existente no espaço escolar.

Diante disso, nós, enquanto professores de escolas ocupadas na época, propomos este trabalho como uma reflexão inicial apresentando alguns apontamentos elaborados à partir das experiências vividas no próprio processo de convivência e construção das ocupações escolares nos Colégios Estaduais Alfredo Parodi e Rodolpho Zaninelli, ambos ocupados em 2016 e localizados em regiões socialmente periféricas na cidade de Curitiba (mapa 1), buscando refletir questões que depois de alguns meses ainda nos atormentam. O que representou este momento para os jovens mobilizados nestas ocupações? Quais foram as transformações ocorridas no cotidiano destes? Qual a relação entre as ocupações de escola e a vida cotidiana periférica da cidade de Curitiba? De quais maneiras as pautas estudantis estão relacionadas com problemáticas sociais urbanas presentes no dia a dia dos educandos?

Tais questões nos colocam uma reflexão importante a respeito da relação sujeito-objeto no processo de pesquisa. Aqui nos concebemos como implicados, ora como pesquisador, ora como parte da pesquisa nesta discussão. Os fundamentos teóricos da teoria da implicação nos ajudam a aprofundar a análise que aqui pretendemos fazer. 


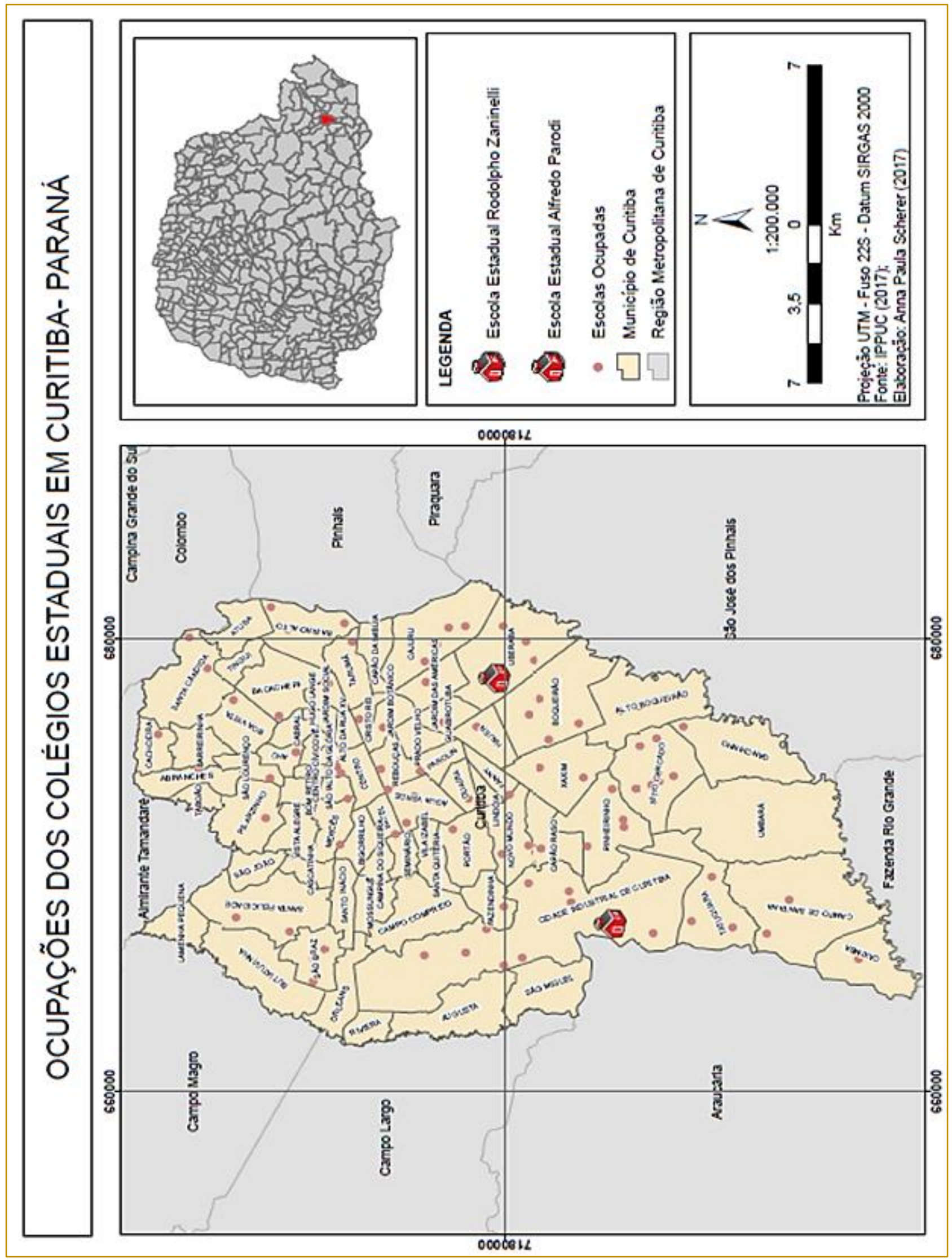




\section{TEORIA DA IMPLICAÇÃO: PENSAR E} VIVER UMA CIDADE, UMA ESCOLA

A ciência fragmenta a realidade na tentativa de explicá-la. Geografia, História, Química, Urbanismo, enfim, cada ciência particular reivindica o seu pedaço, a sua "área" do conhecimento. Mas na medida em que se especializa, ela também se separa, se aliena do todo (totalidade), apesar do progresso individual na produção do conhecimento.

Notado haver esse progresso, permanece a crítica ao método da cisão por alicerçar-se na separação entre o sujeito e o objeto, o que é bastante controverso nas humanidades, onde se sabe não existir uma nítida linha demarcatória entre o território do primeiro e do segundo (se é que tal linha, em quaisquer ciências, existiu algum dia). Embora contestada, a prática da separação sujeitoobjeto infelizmente enraizou-se profundamente no ocidente, sendo aplicada às massas indistintamente.(BAITZ, 2006 p.32)

A Geografia clássica, ao conceber o espaço, liga-se ao conceito de gênero de vida, de Vidal de La Blache, que concebe-se como uma estrutura circular (mais ou menos estável) que correspondia à forma como cada grupo humano desenvolvia sua própria maneira de ser e viver(SEABRA, 2004). As ferramentas do positivismo lógico, predominante da ciência de então, permitiu com que a produção geográfica dos países centrais do capitalismo legitimasse e favorecesse o imperialismo e a exploração do trabalho destes sobre os assim chamados países subdesenvolvidos(LACOSTE, 1975). No entanto, com o avanço do modo de produção capitalista, um modo de vida propriamente urbano se generaliza a toda a sociedade, englobando desde as cidades até os mais profundos rincões do mundo, transformando as relações de indivíduos, famílias e comunidades inteiras com o Espaço, tornando-o estático e programado.

Tal concepção, levada à cabo em especial pela teoria dos sistemas e pela Geografia pragmática (SANTOS, 2010) tem suas origens ligadas aos eleatas da Grécia antiga. Trata-se de uma concepção (ideologia) ligada ao poder, pois estes - os eleatas - construíam à época a teoria de uma realidade estática, imóvel, sendo, portanto, eterno o poder das classes dominantes e do Estado grego sobre os povos que este dominava. Heráclito se contrapõe ao espaço estático, colocando-o em movimento e expondo os limites e contradições do pensamento dominante. Não à toa Marx vai estudá-lo em seu doutorado (LEFEBVRE, 1988). Pensar o espaço assim, como absoluto, - um Novo Eleatismo, diria Lefebvre - é uma ideologia potente, pois este mesmo espaço contém pensamentos e práticas (concebido e vivido) que nele se desenvolvem. O uso de imagens preenche de conteúdos o vazio de uma suposta neutralidade espacial, criando representações e junto delas uma fé nestas mesmas representações que pretendem conduzir de maneira cartesiana a produção do espaço (LEFEBVRE, 1980).

Assim, grande parte dos processos de transformação na sociedade - e em consequência do espaço - são representadas como mudanças abstratas no campo da ordem e da lei. É como se ter ou não aprovada tal ou qual norma, lei ou regra transformasse a vida cotidiana simplesmente por sua manifestação na forma jurídica, e não nos conflitos sociais reais e na luta de classes que implicam vitórias e derrotas para tal ou qual setor desta mesma luta de classes.

Desta forma, se retira o histórico do espaço e ele se autonomiza. Mas quando se acessa o plano do vivido, podemos ao mesmo tempo acessar os conteúdos da desigualdade da economia moderna. Precisamos pensar em uma Geografia que narre o cotidiano, o vivido, - implicado. Só assim poderemos compreender como os processos que estudamos no nível ${ }^{70}$ econômico, no macro, na totalidade, rebatem no dia-a-dia daqueles sujeitos que não passam de números nas cadernetas dos planejadores e políticos. Precisamos pensar uma Geografia em movimento!

Nesta tentativa, como professores que estiveram em ocupações de escolas e que misturaram-se aos secundaristas ocupados, encontramos na teoria da implicação uma

70 Compreendemos a noção de nivel à partir de Henri Lefebvre, onde esta se coloca como termo médio entre formae sentidona relação sujeito-objeto. A forma se trata da capacidade de decifrar um objeto em partes menores, em escalas mas próximas, íntimas. A forma urbana pode ser decifrada no cotidiano, por exemplo. O sentido é a capacidade de integrar este mesmo objeto a unidades maiores, de escala ampliada, tal como a cidade que se molda aos fluxos do capitalismo financeiro global. A noção de nível atravessa a forma, o sentido e a estrutura, implodindo-os. A estrutura segmenta, o nível, pensado como escala, põe em relação o sujeito, o objeto e a totalidade. Ver Henri Lefebvre. Posição contra os tecnocratas. Nova Crítica. 1988. Em especial o capítulo "A noção de nível". 
base teórica para dar conta de explicar um processo de movimentação social do qual fizemos parte.

\section{E o que é o conceito de implicação senão esta proximidade - consciente - do sujeito com seu objeto, este envolvimento com o outro que retira a distância criada artificialmente pelo método formal? (BAITZ, 2013)}

Somos pesquisadores, vivemos na cidade. Como podemos pensá-la ignorando nossas vivencias nesta mesma cidade? Como podemos construir um pensamento geográfico ignorando a classe da qual viemos, nossos interesses pessoais em investigar tal ou qual questão, a nossa vivência pessoal com a cidade? A ciência que se esconde atrás da máscara da neutralidade oprime as classes mais baixas, uma vez que o desenvolvimento de conceitos produzidos à partir de seus dogmas é usado como ferramenta nas mãos de uma burguesia que o utiliza para ampliar seus lucros. Quantos pesquisadores não se desculparam ou se lamentaram pelos usos que foram dados a suas criações? Então cabe-nos perguntar, porque manter-se como distante daquilo que estudamos? Porque como pretensos sujeitos, nos negamos a nos colocar também como objeto de investigação e reflexão? Porque não refletirmos sobre o nosso próprio exercício enquanto pesquisadores?

A implicação trata-se disto, de romper com esta - frágil - fronteira existente entre sujeito e objeto, buscando um movimento de pensamento que supere a ambos. Assim, é possível pensarmos o vivido, a vida cotidiana.

Esse método não diretivo trás em seu bojo a possibilidade de todos serem pesquisadores, pois a medida que ela dita que aspectos mínimos e íntimos do pesquisador podem - e devem - vir à tona, todas as pessoas são convidadas a fazer ciência, a serem cientistas, e o importante: a refletir sobre esta atividade. É um duro golpe à ciência burguesa e aos pesquisadores de sangue puro. (BAITZ, 2006 p. 41-2)

Para isso, descemos até a vida cotidiana, convivemos com misérias e carências dos diversos tipos, e pudemos sentir o tamanho do peso que cai sobre o morador de periferia em uma cidade como Curitiba. Pudemos compreender que as ocupações de escola ainda não foram devidamente compreendidas como um fenômeno social que explodiu levando em conta a reivindicação de uma série de carências que ultrapassavam o âmbito das reformas de governo proposta pelos Projetos de Emenda Constitucional 55 e 281. Vivemos na pele o morador periférico, e as questões sociais, raciais e de gênero que esta condição implica. Entramos no íntimo das escolas para pensá-las desde dentro. A vida cotidiana articula Espaço e Tempo ${ }^{71}$.

\section{PRIMEIRA IMPLICAÇÃO: O COLÉGIO ESTADUAL ALFREDO PARODI}

Localizado na parte conhecida como "Uberaba de baixo", pertencente ao bairro de mesmo nome (Uberaba), cuja área abrange a bacia das nascentes do rio Iguaçu, o Colégio Alfredo Parodi situa-se na periferia da região leste de Curitiba, próximo à divisa com o município de São José dos Pinhais, residido por uma população de classe média baixa e baixa, com renda média mensal de 1 a 2 salários mínimos per capita, conforme o IPPUC - Instituto de Pesquisa e Planejamento Urbano de Curitiba - (2010).

Para chegar ao colégio, há basicamente duas formas: via Terminal do Hauer ou pelo Terminal do Centenário com o ônibus "Centenário/Hauer". Este ônibus passa pela avenida principal da região, a "Avenida dos Trabalhadores", o qual, entre ônibus lotados e antigos, transporta diariamente a população para o centro e os demais bairros da cidade. Levando em consideração que o Uberaba é o quinto bairro mais populoso de Curitiba, com 72.056 habitantes (IBGE, 2010), a oferta de ônibus para o "Uberaba de baixo" é baixa, sendo o Centenário/Hauer a única linha que faz a interligação com outros bairros. Ressalta-se além do mais que a região engloba várias áreas de ocupações irregulares.

De acordo com dados fornecidos pelo IPPUC (2010), das 381 ocupações existentes em Curitiba, 22 situam-se no Uberaba. Outro dado comparativo é a relação da população por cor, idade e gênero: enquanto que em Curitiba $78 \%$ da população é branca e 18\% é parda e preta, com idade média de 33 anos e majoritariamente feminina (52,33\%), no

71 "O cotidiano urbano prolonga e explicita o sentido da urbanização capitalista pela generalização de um modo de vida no qual foram sendo aprofundadas as separações no âmbito da vida social." SEABRA, Odette Carvalho de Lima. Territórios de uso: cotidiano e modo de vida. In: CIDADES. v. 1, n. 2, 2004, p. 183 
Uberaba tais índices se destoam em alguns aspectos. No referido bairro $23 \%$ da população é parda e preta e $75 \%$ branca, com idade média de 31 anos e também em sua maioria do sexo feminino. Apesar de não apresentar grandes mudanças se analisada comparativamente com Curitiba, o maior índice de pardos e negros se verifica no padrão de alunos que freqüentam o Colégio Alfredo Parodi, cujos, segundo o Projeto Político Pedagógico da escola (PPP, 2012):

Em sua maioria residem em área de ocupação irregular, o que os condiciona a uma situação de violência, abuso, drogadição, alcoolismo, prostituição e privação do direito a satisfação de suas necessidades básicas. A maioria das famílias é assistida por programas sociais (bolsa família, leite das crianças, dentre outros), ou ainda, sua atividade de trabalho se faz pelo serviço doméstico, coleta de materiais recicláveis, auxiliares de produção, o que os permite a uma renda básica que varia de meio salário a três salários mínimos. (PPP ALFREDO PARODI, 2012, p.16)

Os dados podem revelar algumas particularidades da segregação e exclusão socioespacial em Curitiba, submetida à população pobre, negra e periférica, cabendo a escola (e isto inclui nós professores) a receber esses educandos, aprender a lidar com suas realidades e tentar contribuir com a formação social desses adolescentes.

Ademais, como uma forma de se "resolver" as problemáticas sociais e a violência da região, inspirado nas Unidades de Polícia Pacificadoras do Rio de Janeiro, em 2012, fora implantada no bairro a primeira Unidade Paraná Seguro (UPS) do Estado do Paraná. O objetivo seria levar as políticas públicas para a região, com ações sociais, de geração de renda, atividades em contra-turno escolar e melhoria da infraestrutura. ${ }^{72}$ No entanto, desde então, não houve melhoria na disponibilidade de serviços para os moradores. Conforme relato dos próprios educandos do Alfredo Parodi, o que se verificou fora apenas o aumento da repressão policial, principalmente com os moradores negros e advindos das áreas de ocupação irregular do bairro.

Enfim, o intuito de se descrever brevemente a realidade do bairro onde se encontra 0 Colégio Estadual Alfredo Parodi é demonstrar

72 http://exame.abril.com.br/brasil/policia-ocupa-bairrode-curitiba-para-implantar-upp-3/ que o processo de ocupação feito pelos estudantes perpassa os muros da escola, uma vez que pode ser encarado como o estopim de uma ação sinalizadora, reivindicadora de visibilidade por parte desses jovens - pois a Medida Provisória mexeu com o espaço de maior convívio e troca de relações dos jovens: a escola -, que, durante suas vidas têm sofrido violência (das mais diversas formas) exclusão aos seus mais direitos básicos, como o acesso a transporte público, moradia, educação de qualidade.

É nesse sentido que, ocupado entre o mês de outubro e novembro pelos seus estudantes, o "Alfredo", ou "Parodi"é o típico e estigmatizado perfil de escola pública de periferia, uma vez que apresenta graves problemas de evasão escolar, violência, falta de professores, recursos e estrutura física.

Boa parte dos educandos que ali estudam são moradores das ocupações localizadas no entorno da linha do trem que corta o bairro e da várzea do Iguaçu, conhecidas como Vila Itibere e Vila Icaraí.

O Alfredo Parodi é o colégio mais próximo dessa região e por conta disso é o principal local onde as famílias residentes dessas vilas estudam ou estudaram. Devido a isso, a relação de proximidade e parentesco entre os estudantes é muito grande, criando assim um forte elo de amizade e união entre os mesmos que se mostra em momentos como os horários de entrada e saída da escola (chegam e vão embora juntos e em grupos) e no cotidiano das aulas (se conhecem e possuem amigos de turmas e turnos diferentes).

Ademais, a escola atende, segundo a Secretaria de Estado da Educação do Paraná a 1068 alunos, com idade média entre 10 e 40 anos, possuindo em sua administração, 1 diretor geral, 2 diretores auxiliares, 3 pedagogas, 60 professores e 18 funcionários. Além disso, um acontecimento comum é a alta rotatividade de professores e a contratação de funcionários temporários para trabalharem nas funções administrativas e nos serviços gerais. Entre os motivos que podem explicar tal processo destacam-se a localização da escola no extremo leste de Curitiba, a falta de opção de ônibus no transporte público e a difícil realidade dos alunos (que se espelha no comportamento).

Ao entramos no "Alfredo Parodi", vemos que carência de espaço físico para serem realizadas atividades com os educandos. As 
aulas ocorrem nos três turnos. O refeitório serve como salão de apresentações e possui uma televisão e equipamentos para se instalar o único aparelho projetor da escola. Em sua maioria, as salas de aula não possuem cortinas, contém muitos vidros quebrados, nem todas as lâmpadas funcionam, as carteiras e os quadros de giz contém defeitos. Não há muitos equipamentos e materiais para os professores utilizarem como apoio nas aulas, até mesmo a internet da escola não funciona direito. De cor marrom, a pintura das paredes é antiga e pouco agradável e aconchegante. Há duas quadras de vôlei improvisadas e uma quadra poliesportiva onde são ministradas as aulas de educação física e onde acontecem os eventos maiores e assembleias. Ademais, no cotidiano das aulas, as turmas são superlotadas (entre 35 e 40 alunos em média) e é comum alguma estar "em aula vaga" devido à falta ou ausência de professor.

Em meio a essa realidade e diante da noticia da Reforma do Ensino Médio e proliferação das ocupações em outras escolas públicas, os educandos, ou melhor, as educandas tendo em vista que o movimento foi liderado por meninas - decidiram se organizar para ocupar o Alfredo Parodi, iniciando pela realização de assembléias e reuniões com a comunidade escolar. Tal organização durou cerca de 1 mês e teve como maior apoio (a princípio) os professores e a direção da escola. Durante a ocupação, os estudantes de faixas etárias diversificadas - se organizaram em brigadas (alimentação, limpeza, oficinas) e no dia a dia realizavam ações diretas (nas ruas, voltadas para a comunidade), atividades práticas (principalmente de reparo em espaços depredados da escola), discussões e debates sobre temas que os interessavam e envolviam seu cotidiano, como violência policial, racismo, o impacto da reforma do ensino médio, vestibular, o papel da mulher na sociedade, oficinas de graffiti, hip hop, funk, entre outros.

Das mais de 800 escolas ocupadas, o Colégio Estadual Alfredo Parodi foi um dos últimos a desocupar. Este acontecimento é considerado marcante tanto para os educandos como para a história da escola, pois nunca havia ocorrido uma organização, união e mobilização como esta por parte dos estudantes, tendo em vista que muitos dos alunos que ocuparam eram considerados por parte dos professores como "alunos problema", desinteressados, "sem perspectiva de vida". Nesse sentido, as ocupações apontam que o problema pode estar na estrutura da educação, tal como ela se apresenta organizativamente no cotidiano dos educandos e que estes possuem demandas e anseios que vão além da reivindicação pela não aprovação de uma reforma, mas que buscam pensar sobre melhores condições de vida e oportunidades em meio à uma realidade urbana excludente e segregadora.

\section{SEGUNDA IMPLICAÇÃO: O COLÉGIO ESTADUAL RODOLPHO ZANINELLI}

Subimos no ônibus Vila Verde, à partir do Terminal do $\mathrm{CIC}$, onde um grande número de pessoas se locomovem em um ônibus simples, bastante diferente daqueles vendidos como de última geração pela prefeitura de Curitiba. Quem espera encontrar nesta linha $\mathrm{o}$ transporte modelo que $\mathrm{O}$ município vendeu para o mundo pode se surpreender negativamente. São ônibus antigos, lotados, barulhentos, sem escapamento, irregulares em horários e que quebram com uma frequência relativamente alta. Nesta linha não há contrafluxo, visto que quando chega ao terminal, o ônibus trás um grande volume de pessoas que saem da Vila Verde rumo aos seus locais de trabalho em outras regiões da cidade, e na volta leva um grande número de operários das várias fábricas que existem na região, tais como a Bosch e a Racco. Seguimos pela Rua Des. Cid Campelo, entrando pela Rua Vicente Micheloto onde, ao passar pelo viaduto há um ponto de ônibus bastante movimentado, pois é onde os moradores do bairro conseguem pegar o ônibus sem que este faça todo o trajeto pela região até seu ponto final, economizando mais ou menos 15 minutos. A Avenida - onde circulam muitos carros em suas três pistas em cada sentido, dado ser uma das principais ligações com o município vizinho de Araucária - possui paradas nos dois lados da pista e, apesar disso, não há ponte ou semáforo que auxiliem os pedestres na realização desta travessia. São muitas as pessoas que se arriscam nesta desigual disputa de tempo e de espaço com os carros em alta velocidade, e as crianças e idosos são os que mais apresentam dificuldade em cruzar de um lado da rua para o outro.

Entramos na Vila Verde e a primeira coisa que nos chama atenção é a névoa cinza e com 
mau cheiro que envolve o bairro todas as manhãs. As ruas, em sua maioria já asfaltadas, apresentam construções simples e por vezes inconclusas. São casas construídas pelos próprios trabalhadores que ali vivem desde que este terreno fora ocupado, no ano de 1991, quando à partir da atual rua Emílio Romani passaram a construir as casas e as estruturas básicas do bairro na forma de mutirões. Trata-se de um bairro estigmatizado por uma imagem, veiculada cotidianamente nas redes de TV e jornais, ligada à pobreza, ao tráfico de drogas e à violência urbana. No entanto, ao desvendar as entranhas do bairro, as pessoas reais que vivem e trabalham todos os dias, sustentam suas famílias à duras penas. Observamos que grande parte dos habitantes aqui ou são migrantes, ou são descendentes diretos destes que vieram de áreas rurais das mais variadas no Brasil, em especial do interior do Estado do Paraná.

Existem poucas estruturas de cultura e lazer para que os jovens possam desfrutar, entre elas está o Bosque da Vila Verde, um campo de futebol, localizado na Rua Ney Pacheco, e - teatro Peça por Peça, mantido pela Fundação Bosch. No restante, faltam opções para além das igrejas (Comunidade Santa Clara, Deus é Amor, Assembléia de Deus e Universal do Reino de Deus) e bares, que pipocam em cada rua por aqui. $O$ bairro conta também com uma creche municipal; duas escolas municipais (E.M. João Cabral de Melo Neto e E.M. América da Costa Sabóia); e o Colégio Estadual Rodolpho Zaninelli. No entanto, aqui começa-se a trabalhar desde muito cedo. Desde antes de entrarem no Ensino Médio muitos jovens trabalham, desde programas de estágio como 0 Jovem Aprendiz até trabalhos informais, como caixas de mercados locais e vendedores de frutas e doces em semáforos. O número de pessoas negras no bairro é evidentemente expressivo, se contar que Curitiba se vende com a imagem de uma cidade europeia.

O "Rodolpho", como é chamado pelos moradores, é o local onde grande parte da população desta região estuda ou estudou. É comum que pais e filhos tenham assistido aulas com os mesmos professores. Nas listas de chamada muitos sobrenomes se repetem de uma sala para outra. São primos, tios, irmãos, enfim, grande parte do núcleo familiar das pessoas que aqui vivem que passam um bom pedaço de suas trajetórias de vida. Atende um número de alunos de 1604 com faixa etária entre 10 e 40 anos com 1 diretor, 2 diretores auxiliares, 1 secretária, 7 pedagogas 83 professores e 24 funcionários oferecendo cursos do Ensino Fundamental II, Médio e Técnico de Administração e Mecânica. Apresenta também apoio financeiro escasso para adequar as instalações e materiais às necessidades de educadores e educandos além da alta rotatividade de professores.

Ao entrar, pode-se surpreender com a quantidade de cadeados e portões que existem delimitando os diferentes espaços. Para evitar com que os educandos fujam das salas de aula, portões são trancados por correntes e cadeados, onde há uma agente escolar responsável por abrir e fechar para que os professores possam trocar de turma, e também para que um ou outro que precise ir ao banheiro. O espaço físico também não é dos mais agradáveis. As paredes são pintadas em tons de azul que, no entanto, nos pontos onde estão descascadas se expõe uma miscelânea de outras cores que estas mesmas salas de aula já possuíram. À exceção das paredes e portas que foram desenhadas por um projeto da professora Silvia, de Artes, falta bastante cor por aqui. Faltam também alguns vidros nas janelas de parte das salas de aula, o que no inverno curitibano torna a experiência de assistir/ministrar aulas bastante desagradável.

O lanche não é tão diversificado nutricionalmente, tendo em vista que boa parte dos educandos precisa se alimentar na escola. É frequente que tenham apenas bolacha e água e sal e chá mate como merenda para suportar 5 horas de aula. Para muitos dos que estudam e trabalham, uma boa comida na hora do lanche faz toda a diferença, ainda mais para aqueles jovens que ficam sozinhos em casa com os irmãos, sem a presença dos responsáveis - que precisam trabalhar o dia todo - e não possuem acompanhamento para que realizem suas refeições de maneira adequada. É uma escola com o estigma da "escola que deu errado".

A partir notícia da ocupação da Escola Estadual Arnaldo Jansen ${ }^{73}$ - no município de

73 "Alunos que ocupavam escolas estaduais deixaram na tarde desta sexta-feira (4) dois colégios em São José dos Pinhais, na Região Metropolitana de Curitiba, após o cumprimento de mandado de reintegração de posse por oficial de justiça. A primeira desocupação foi no Colégio Estadual São Cristóvão. Em seguida, os estudantes saíram do Colégio Estadual Arnaldo Jansen, o primeiro a ser tomado por secundaristas no Paraná. A unidade estava ocupada há 31 dias." Em Gazeta do Povo no dia 04/11/2016 com o 
São José dos Pinhais, na Região Metropolitana de Curitiba - os estudantes realizaram algumas reuniões e assembleias que culminaram na ocupação do Rodolpho Zaninelli. Os estudantes que permaneceram ocupados na escola foram aqueles que são tidos pela maioria dos professores como indisciplinados, os chamados "alunos problema". No entanto, o que se observou era uma escola organizada, mais limpa do que de costume, onde os estudantes fizeram reparos em espaços degradados por conta própria e buscavam atividades para preencher a programação diária da ocupação.

Ocorreram saraus, oficinas (Hip Hop, educação popular, filmagem e edição de vídeos, etc.) shows de bandas, campeonatos de futebol e volei, assembléias, reuniões, formações políticas com professores de outras escolas e universidades, enfim, a escola se tornou realmente atrativa para aqueles jovens. Mas para mais além disso, era possível ver a comunidade se reapropriando da escola, onde pais e responsáveis e até moradores que já terminaram seus estudos se faziam presentes com grande frequência nas atividades. As alunas, no geral, eram as protagonistas no processo político e organizativo que ocorria por aqui.

Mas um vento frio perturbou a doce harmonia da cesta. A propaganda midiática e do governo do Estado do Paraná passaram a estimular com que os pais se organizassem, muitas vezes de maneira violenta, para desocupar as escolas. Movimentos como o MBL (Movimento Brasil Livre) passaram a produzir conteúdos que visavam degradar a imagem dos estudantes ocupados em escolas, gerando um clima de apreensão e medo entre os estudantes. As ameaças, denuncias e processos que começaram a chegar aos professores que apoiavam este processo tratou de desarticular grande parte do apoio que estes estudantes tinham. A comunidade parou de frequentar as ocupações, uma vez que se difundiam boatos de que estas eram utilizadas para o consumo de drogas e a realização de orgias entre os estudantes. As doações de comida e estrutura que vinham por parte dos

título "Justiça cumpre reintegração de posse na primeira escola ocupada no Paraná". ver: http://www.gazetadopovo.com.br/vida-e-

cidadania/justica-cumpre-reintegracao-de-posse-naprimeira-escola-ocupada-no-parana-

9c8ukozo5o97su2388srahz0w Acesso em 25/06/2017. apoiadores diminuiu gradualmente, até o momento em que passou a faltar, inclusive, comida na ocupação. No momento em que ficaram isolados foi justamente onde os jovens do Colégio Estadual Rodolpho Zaninelli se mostraram mais fortes, pois tiveram de enfrentar, além de toda a estrutura repressora do Estado e de grupos de direita, os próprios pais e professores que, no início do processo, os apoiavam.

Diversas reuniões foram organizadas por professores da escola junto à comunidade no intuito de forçar a desocupação do Rodolpho. Até que no dia 09 de Novembro de 2016, cumprindo a um mandato de reintegração de posse da parte do Governo do Estado do Paraná, a Polícia Militar desocupa o colégio, o último em todo o Estado. Alguns dos estudantes se assustaram neste momento, pois parte dos policiais escalados para executar a reintegração eram os mesmo que cometeram violências e intimidações com os estudantes em vários momentos do dia-a-dia das ruas. A \#OcupaRodolpho terminou, mas permaneceu como um presente ausente, e seus rebatimentos na vida escolar e na consciência de todos os que participaram ou não - deste processo. A vida seguiu, mas desde então, já não é a mesma de antes.

\section{A LUTA PELA ESCOLA COMO UMA LUTA POR DIREITO À CIDADE}

A memória, a lembrança, enfim, trazer à tona uma representação de um passado ao presente, não é simplesmente rememorar algo que passou, mas trazer uma carga histórico-espacial do passado, atualizá-la no presente e projetá-la ao futuro. Para Lefebvre, memória dos combatentes substitui os combates (LEFEBVRE, 1980).

O momento da forma é congelado, mas a teoria das representeções tentar dar conta de expor o movimento concreto da relação forma-conteúdo existente nas relações espaciais. A forma urbana, ela não existe a não ser como utopia. Há uma desconexão, e até uma negação do urbano pela cidade. Os centros das cidades se tornam centros de gestão e administração da crise urbana, construindo representações ligadas ao mundo do trabalho que valem tanto para os trabalhadores das periferias das cidades quanto para os trabalhadores rurais. É O mundo da mercadoria propagandeado e ao mesmo tempo negado a um sem número de pessoas que vão trabalhar o máximo para 
acessá-lo. Ou roubar e matar para conseguir dele alguns restos. A gestão e a "governança" irradiados dos centros das grandes cidades Av. Paulista em São Paulo, Centro Cívico em Curitiba, Brasília, etc.) são a própria negação do urbano (LEFEBVRE, 1980). Basta observar as miseráveis periferias urbanas, os sem teto, os sem terra. Aqui, de perto, podemos enxergar uma relação íntima entre as representações do poder e a organização do trabalho no modo de produção capitalista.

Tratam-se de um sem número de indivíduos que vivem o mínimo, as sobras do modo de produção no corriqueiro da vida. Existe uma interação íntima entre a colonização, o desenvolvimento técnico e assim chamado subdesenvolvimento, tanto ao nível da economia global capitalista, quanto no tecido da vida cotidiana. A vida cotidiana aparece, neste modo de produção, como repetição espacial não só dos tempos de trabalho, mas também do ócio e da consciência, criando um processo que podemos chamar de alienação espacial. É o subdesenvolvimento da vida cotidiana (LEFEBVRE, 1980).

Se pensarmos conforme Marx, em sua crítica da filosofia do direito de Hegel (2006), no momento da constituição do Estado moderno suprime-se as particularidades locais - o direito comunitário, a autonomia política das vilas, etc. - no sentido de uma homogeneização das diferenças sob uma ordem única: o direito continental. $E$ isso independente das necessidades comunitárias, com o objetivo de quebrar os laços estáveis comunitários, instituindo relações sociais pautadas no individualismo (a ideia de individualidade é moderna!) e ampliar, assim, as trocas comerciais. A alienação política é essencial na constituição deste processo, uma vez que uma organização política que se dê desde a base - formas autogestionárias - questiona a estrutura Estado-Capital em seus fundamentos objetivos e subjetivos. A escala do Estado deve, necessariamente, negar todas as outras escalas da política que não são as do Estado e do Capital. (RAFFESTIN, 1993).

Para Hegel - na leitura feita por Marx (2006) há uma identidade abstrata - que podemos entender como uma igualdade jurídica criada entre os sujeitos e os "estamentos" sociais em torno do Estado. A separação entre a política e a vida cotidiana evidencia , a partir do momento em que se pensa concretamente em uma sociedade de classes, uma separação e uma diferença entre os sujeitos que é, também, social, e esta diferença, própria da "sociedade civil", segundo a inversão lógica feita por Marx (2006) mostra um Estado que, apesar de uma pretensa igualdade jurídica - "identidade ilusória" - recria nesta esfera - Estatal, jurídica, etc. - as desigualdades presentes nesta mesma sociedade de classes. A forma jurídica, portanto, encobre e, ao mesmo tempo legitima as diferenças sociais administradas e mantidas pelo Estado. Se pensarmos conforme SEABRA (2004).

O cotidiano urbano prolonga e explicita o sentido da urbanização capitalista pela generalização de um modo de vida no qual foram sendo aprofundadas as separações no âmbito da vida social. (SEABRA, 2004. p. 2)

A escola, como parte da sociedade, não está alheia a isto. Já que esta é a principal responsável por transmitir os valores da sociedade vigente, é nela, também, que se materializam grande parte das misérias vividas no cotidiano dos moradores de periferia em grande parte deste país. Para uma cidade pretensamente europeia, qual o interesse em revelar os conteúdos e reivindicações de uma juventude em grande parte negra e nordestina? A estes jovens, de escolas públicas de bairros pobres, nunca foi dada a oportunidade de pensar o bairro e a escola como problemas muito maiores que a mera relação entre professor e aluno. Foi na relação destes em um movimento maior, autogerido, é que surgiram questionamentos acerca da própria realidade onde vivem. Onde estão as áreas de lazer do bairro? E os equipamentos que deveriam existir na escola e não são encontrados? E porque a escola tem equipamentos que não são utilizados? Porque as formas pedagógicas utilizadas em nossas escolas são as piores possíveis? Conseguirei uma boa inserção no mundo do trabalho com a escola que tenho? Como posso superar, junto a outros, a minha condição?

Alguns meses após as ocupações de escolas no Paraná, surge uma efetiva mudança na vida destes jovens, que decidiram questionar, por vias autogestionárias, o Estado, que propunha reformas que tornam ainda mais miserável a educação que tinham. No retorno às aulas, apesar das pressões sobre os professores para que tudo se mantivesse como antes, algo se transformou. De repente tínhamos debates sobre gênero, raça, casse social e educação popular partindo dos 
próprios educandos. Tínhamos estudantes realocados para escolas longe de suas residências, sofrendo as mais diversas perseguições da Secretaria de Educação, das direções de escolas e da polícia no bairro. Tínhamos embates entre educadores e educandos dentro das salas de aula onde se questionava a estrutura da aula ou o conteúdo que se passava. Questiona-se a falta de debates e de participação dos estudantes e da comunidade em seu próprio processo formativo. Compara-se a estrutura de tal ou qual escola, que conheceram no processo de ocupação e reunião entre secundaristas com a estrutura da escola em que estudam. Formam-se redes, grupos de Whats App, atos, manifestações. Secundaristas fazem-se presentes nas reuniões e assembleias do sindicato dos professores, tensionando com um burocratismo destas instituições que os próprios educadores já se cansaram de enfrentar.

Se de fato as escolas ocupadas trouxeram um legado, não está em sua vitória frente a pauta que reivindicavam, até porque a reforma do Ensino Médio e a PEC do congelamento de gastos contra as quais os estudantes lutaram foram aprovadas, à base de intensa violência, em Brasília. Mas há que se perguntar: a comuna de Paris fracassou ou não? As irrupções de 1968? Junho de 2013? Estes momentos expressam um campo de inúmeras possibilidades reunidas e não necessariamente realizadas, mas que atravessam a história como possívelimpossível.

A obra, aqui, mobiliza o afeto. São as reuniões de bairro, os vínculos de pertencimento. Nas duas ocupações sobre as quais aqui refletimos, houveram pertencimentos ao bairro e a escola que foram evidenciados em muitos momentos, desde os fóruns na internet (\#ocupaparodi e \#ocuparodolpho) até nas reuniões e fóruns públicos no centro da cidade, onde cada escola ocupada entoava seu grito de guerra. Mas também houveram rupturas com bairrismos, quando na tentativa de desocupar escolas como o Pedro Macedo, secundaristas de vários pontos da cidade se reuniram e enfrentaram, muitas vezes com brigas físicas, os grupos interessados nas desocupações. E neste sentido, cabe salientar o protagonismo das escolas periféricas nas mobilizações, que levavam além das pautas relativas as reformas educacionais, reivindicações relativas a vida em seus bairros.
Nas condições do mundo moderno, só o homem à parte, o periférico, o anômico, o excluído da horda (...) tem a capacidade criadora. O que tem mais oportunidades de criar obras não seria o homem das fronteiras? (...) o homem das fronteiras suporta uma tensão que poderia matar outros: ele está ao mesmo tempo dentro e fora, incluído e excluído, sem, por isso, dilacerar-se. Vivida esta contradição se acrescenta a todas as que esse homem descobre. O homem das fronteiras segue veredas que inicialmente surpreendem, tornam-se depois caminhos, para por fim, passarem por evidências. Ele caminha ao longo dos divisores de água e escolhe a via que vai em direção ao horizonte. Às vezes passa ao longo de terras prometidas, sem entrar nelas. Essa é a sua prova. Sempre vai para outras terras, para o horizonte dos horizontes, de momentos em momentos, até vislumbrar as linhas longínquas de um continente inexplorado. Descobrir é sua paixão. Só pode caminhar de descoberta em descoberta, sabendo que para avançar é preciso vencer uma necessidade de aprofundar o saber, que the sugerisse parar aqui ou ali. (BAITZ, 2013)

$\mathrm{Na}$ dificuldade de fechar este pequeno artigo trazendo à tona todos os pontos dos quais poderíamos desdobrar as ocupações de escola no Paraná, pensemos, sobretudo, em Curitiba: a lógica do capitalismo é a de produzir cidades cada vez mais desiguais. Se a produção do Espaço, de maneira geral, é desigual e violenta, - como podemos observar cotidianamente nos conflitos urbanos e rurais - admite-se que as cidades produzidas sob este modo de produção reproduzam a mesma desigualdade e violência do processo geral de acumulação de capital. O planejamento urbano é segregador na medida em que tenta organizar uma (des)ordem que é o produto do próprio modo de produção em que vivemos, mas que se impõe como um processo "natural" de uma urbanização "sem controle" (LEFEBVRE, 2008). O urbanismo serve, portanto, para amortecer os conflitos cada vez mais intensos e violentos gerados na luta de classes no campo e na cidade.

Até que ponto uma cidade que à partir do planejamento urbano recria a segregação condomínios fechados, favelas, guetos, etc. pode-se dizer uma "cidade modelo", ou mesmo uma "cidade global"? A resposta talvez esteja na afirmação de que um planejamento que não intervém na estrutura 
social capitalista não é capaz de organizar cidades a não ser para garantir a obtenção de lucro para os rentistas e proprietários fundiários. No entanto existem fissuras que expõem as contradições gerais da sociedade vigente e encontram a resistência dos grupos que são afetados de maneira negativa por esses projetos. A resistência mais radical vêm daqueles que necessitam resistir pra sobreviver, dos que não tem outra alternativa.

Portanto, a luta social, que a princípio evoca a um reformismo (direito à moradia, mobilidade urbana, reforma agrária, etc.), apesar de negligenciada pela esquerda tradicional, desenvolve, no próprio processo de resistência, uma consciência política que transcende a luta por direitos e muda seu sentido para uma luta por outra vida, um outro projeto de sociedade, onde enxerga-se mais claramente a luta de classes. A luta por uma casa, por escola, por alimentação tem o seu valor no momento em que, no próprio processo de luta por direitos, rompe-se com o cotidiano totalmente envolvido com a lógica do trabalho. Os participantes de coletivos e movimentos sociais constroem processos autogestionários interessantíssimos que são pedagógicos para que se almeje uma luta mais ampla de superação do capitalismo e do modo de produção. Para Harvey:

Para muitos na esquerda tradicional (o que para mim significa principalmente partidos políticos socialistas e comunistas e a maioria dos sindicatos), a interpretação da geografia histórica dos movimentos políticos urbanos vem sendo prejudicada por suposições

\section{REFERÊNCIAS}

[1] BAITZ, Ricardo. Implicação, um sedimento a se explorar na Geografia? In Boletim Paulista de Geografia. n. 84. 2006.

[2] BAITZ, Ricardo. O Método oswaldradino: uma leitura pela lente da análise institucional e da teoria da implicação. In: Revista Fronteiraz. n. 11. 2013

[3] GIROTTO, Eduardo Donizeti; PASSOS, Felipe Garcia; CAMPOS, Larissa; OLIVEIRA, João Victos Pavesi. A Geografia da Reorganização Escolar: Uma Análise Espacial à Partir da Cidade de São Paulo.

[4] HARVEY, David. Cidades Rebeldes. Martins Fontes.São Paulo. 2014.

[5] LACOSTE, Yves. Os países Subdesenvovidos. DIFEL/Saber Atual. São Paulo. 1975. políticas e táticas apriorísticas que conduzem a uma subestimação e incompreensão da potência desses movimentos para deflagrar uma mudança não apenas radical, mas revolucionária. Os movimentos sociais urbanos são constantemente vistos como algo, por definição, separado ou subordinado às lutas de classe e anticapitalistas que têm raízes na exploração e alienação do trabalho vivo na produção. Se é que os movimentos sociais urbanos chegam a ser, de fato, levados em consideração, são tipicamente interpretados como meros desdobramentos ou desvios dessas lutas fundamentais. Na tradição marxista, por exemplo, as lutas urbanas tendem a ser ignoradas ou repudiadas como desprovidas de potencial ou importância revolucionária. Essas lutas são interpretadas como algo mais voltado para questões de reprodução do que de produção, ou sobre direitos, soberania e cidadania, e, portanto, não sobre classe (HARVEY, 2014 p. 217).

Em Curitiba, onde boa parte do jogo de poderes que paira sobre a disputa atual pelo Estado brasileiro se desenrola; onde a questão da técnica e da ciência sempre se colocaram como superiores a qualquer outra forma de raciocinar; teve dilatadas suas fissuras pelo movimento secundarista que expôs os limites da forma e da lei sobre a vida cotidiana. $\mathrm{O}$ povo fala, cabe ao pensamento de esquerda ouvir, e criar estratégias sobre como agir espacialmente, levando em conta as reais necessidades e projetos destes sujeitos periféricos. Estamos sentados sobre um barril de pólvora, e ele há de explodir.

[6] LEFEBVRE. Henri. Espaço, A produção do Espaço, a economia política do Espaço. In Espaço e Política. Belo Horizonte. UFMG. 2008.

[7] La Presencia y La Ausencia: Contribuición a la teoria de las representaciones. Fondo de Cultura Economica. México. 1980.

[8] Posição contra os tecnocratas. Nova Crítica. 1988. Boitempo. 2006.

[9] RAFFESTIN, Claude. Por Uma Geografia do Poder. Editora Ática. 1993

[10] SANTOS, Milton. Por Uma Geografia Nova. Edusp. São Paulo. 2010.

[11] SEABRA, Odette Carvalho de Lima. Territórios de uso: cotidiano e modo de vida. In: CIDADES. v. 1, n. 2, 2004, p. 181-206 


\title{
Bapítulo 13
}

\section{PROYECTAR DESDE LA ESENCIA DEL HABITANTE. FORM FOLLOWS LIFE.}

\author{
Ignacio Abad Cayuela \\ Juan Moreno Ortolano
}

Resumen: Nuestro momento presente ha venido acompañado de grandes y entusiastas avances tecnológicos y científicos que nos han permitido indagar en la singularidad y diversidad humana con lentes de gran aumento, sin embargo, son precisamente esos mismos logros los que sugieren o provocan algunas interrogantes: ¿Utilizamos los mapas que revelan la comprensión de las mecánicas del hombre para facilitar su despliegue vital? ¿Hacia dónde dirigimos la mirada cuando proyectamos la vivienda de un individuo, de una pareja, de una comunidad o grupo humano?

Durante los cinco últimos años de trabajo, nuestra experiencia profesional (Estudio de Arquitectura AMo_arquitectura y Arquitectura Humana) nos ha llevado a una búsqueda que pretende dibujar un territorio proyectual más sensible y en resonancia con el habitante potencial. Nos hemos visto empujados a adaptar y utilizar herramientas que permitan la construcción de un mundo social a través de la arquitectura, más imbricado y asertivo. Nuestra propuesta tratará de explicar la emergencia y materialización del caso concreto de una vivienda que comenzó a habitarse hace apenas un año, en Zaragoza. Pretendemos ${ }^{74}$ identificar, por lo tanto, una metodología ${ }^{75}$ arraigada al ser humano, indagando en su bioforma o estructura interna; tratando, en definitiva, de mirar la arquitectura a través de los procesos concretos y específicos de la experiencia del habitar.

Palabras Clave: "Diseño Humano", "Enegrama y eneatipos", "holístico", "humanizar"

"La casa parece ser una extensión y un refugio de nuestra constitución y de nuestro cuerpo."

Juhani Pallasmaa

\footnotetext{
74 El presente artículo amplía y completa algunas de las cuestiones presentadas en el pasado Congreso ALTEHA V Buenos Aires, 2017, y en el Fórum Habitar Belo Horizonte, 2018.

${ }^{75}$ Metodología que aquí pretende mostrarse como aplicable fundamentalmente al campo proyectual de la vivienda y el territorio residencial, entendiendo la vivienda como aquel espacio de cobijo existencial que alberga y recoge de manera más próxima la condición intima, personal, vivencial, familiar e identitaria del hombre, con todos los matices asociados a esta idea. "Una reflexión sobre la esencia de la vivienda nos aleja de las propiedades físicas del hogar para introducirnos en el territorio psíquico de la mente. Nos enfrenta a cuestiones de identidad y memoria, de lo consciente y lo inconsciente, a los remanentes del comportamiento biológico y de las reacciones y los valores condicionados por la cultura." PALLASMAA, Juhani. Habitar. Barcelona: G. Gili. 2016. Págs. 18 y 19.
} 


\section{DEL HOMBRE TIPO AL HOMBRE CONCRETO}

El hombre, a diferencia del resto de las criaturas vivientes que se conocen, es un ser bio-cultural ${ }^{76}$. En su proceso adaptativo y evolutivo va desarrollando formas de expresión cada vez más complejas y sofisticadas, que dan lugar a muy diversos modos de organización y relación con el mundo. Construimos códigos y símbolos; lenguajes que nos permiten elaborar territorios comunes para el encuentro, cuyo fin último sería facilitar el intercambio, y una comunicación más abierta, rica, fluida y potenciadora con nuestro entorno vital. Sin embargo, paradójicamente, no es frecuente que se produzcan avances en esta dirección.

Nos encontramos inmersos en una red sorprendentemente compleja, constituida por capas y capas de condicionamiento, de influencias intergeneracionales y multiculturales. Por fortuna, ya disponemos de cartografías que nos capacitan para ver, tanto el núcleo emergente de cada vida humana, como la forma velada que prevalece en cada individuo, reforzada desde la infancia como consecuencia de la necesidad vital de crecer en relación y convivencia con los demás seres humanos. Esta cubrición se corresponde con una fijación o distorsión cognitiva que es debida a la interferencia organísmica ${ }^{77}$ propia del contexto familiar y cultural en el que se ha desarrollado durante los primeros siete años de vida.

El sistema educativo predominante -que no está adaptado a la singularidad del individuoprovoca en cada uno de nosotros la pérdida

\footnotetext{
76 "Decir que el hombre es un ser biocultural, no es simplemente yuxtaponer estos dos términos, es mostrar que se coproducen el uno al otro y que desembocan en esta doble proposición:

- todo acto humano es biocultural (comer, beber, dormir, defecar, aparearse, cantar, danzar, pensar o meditar);

- todo acto humano es a la vez totalmente biológico y totalmente cultural."

MORIN, Edgar. La unidualidad del hombre.

Disponible en: http://www.gazetaantropologia.es/?p=3508

77 Recogemos aquí la cita entera: "La psicología de los eneatipos es un mapa del carácter o de la neurosis o, dicho en otras palabras, de las variaciones del malestar humano por el oscurecimiento existencial. La visión del doctor Naranjo es transpersonal, y se basa en que la personalidad se forma debido a una interferencia organísmica que implica una deficiente experiencia del Ser, ante lo que la persona desarrolla una pasión, o emoción exagerada, que trata de cubrir ese agujero existencial y que acaba perpetuando esa personalidad." LLORENS, Antoni. La estructura de la nada. Una raíz común entre el eneagrama y el árbol de la vida. Barcelona: Ediciones La Llave. 2016. Pág. 133.
}

de contacto con nuestra propia naturaleza básica $^{78}$, dando lugar al extendido fenómeno de homogeneización social. Los años iniciales de condicionamiento dejan profundas huellas en los registros personales de la memoria. De esta manera quedamos atrapados en una estructura repetitiva y predecible de personalidad, que nos aleja de nuestra naturaleza esencial, pasando a afirmarnos como sujetos previsibles, manipuladores y manipulables; víctimas de programas mentales que nos arrastran a vivir desde un profundo sentimiento de carencia que en la mayor parte de los casos es inconsciente.

Por este motivo, consideramos que resulta apremiante poner en valor las características innatas de cada individuo, sus fuerzas vitales, para que pueda llevarse a cabo una gestión consciente $^{79}$ del torrente energético que lo diferencia del resto de sus semejantes: disponemos de unos mecanismos de funcionamiento propios que nos convierten en absolutamente únicos, diseñados de tal manera que cada existencia es valiosa para desempeñar determinadas funciones dentro de la comunidad humana de la que constituimos una parte esencial ${ }^{80}$.

\footnotetext{
${ }^{78}$ ALMAAS explica: "En su libro, Ennea-type Structures (Naranjo, 1990), Naranjo presenta el Eneagrama en forma de método para la autoobservación y el estudio, como parte de un trabajo de realización espiritual más amplio. Elabora el modo en que las características de la personalidad de los nueve ego-tipos (que Naranjo denomina "enea-tipos") son expresiones de pérdida de contacto con el Ser, nuestra naturaleza básica, y al hacerlo, muestra que el verdadero valor de dicho conocimiento estriba en ayudarnos a restablecer ese contacto." ALMAAS, A.H. Facetas de la Unidad. Barcelona: La Liebre de Marzo. 2002. Pág. 22.

79 Señalamos la importancia vital de la toma de conciencia de que sucede, en cada ser humano, un despliegue natural de sus ciclos: "La evolución no es un proceso continuo y uniforme. Se produce más bien a saltos, con ocasión de ciertos acontecimientos y/o tomas de conciencia. Incluye también regresiones, vueltas sobre los mismos pasos, o lo que parecen ser los mismos
} pasos.

Este proceso no es ni necesariamente ni siquiera frecuentemente consciente. El ciclo tiene lugar con independencia de la voluntad del interesado. Sin embargo, padecerlo o tomar conciencia de él, producen resultados muy diferentes." CAUVIN, Pierre / CAILLOUX, Geneviève. Sé tú mismo. De la tipología de Jung al MBTI. Bilbao: Ediciones Mensajero. 1997. Pág. 90.

80 Ken Wilber apunta: "Los elementos constitutivos de estas jerarquías son los holones, totalidades que, al mismo tiempo, forman parte de otras totalidades.(...) la realidad no está compuesta de totalidades ni de partes, sino de totalidades/parte u holones. En cualquier dominio que la consideremos, la realidad está básicamente compuesta de holones.". Puede verse: WILBER, Ken. Una teoría de todo. Barcelona: Kairós. 2001. Pág. 36. 
La sobreabundancia y proliferación del hombre tipo al que nos referimos, evidencia una señal de alarma que solicita una actualización en la disciplina arquitectónica mediante la utilización de nuevas herramientas de análisis. Gracias a estas cartografías atendemos al reconocimiento y la diferenciación que se pretende, en torno a las situaciones diversas y plurales que se dibujan alrededor del hombre concreto y las formas que habita. ${ }^{81}$

\section{CARTOGRAFÍAS Y ANÁLISIS DEL SER HUMANO}

Ya a finales del pasado siglo, llegamos a ver, a través del estudio de los tipos psicológicos de Jung ${ }^{82}$ y el MBTI $I^{83}$, que cada ser humano cuenta con unas particularidades innatas. Las variaciones en la conducta que observamos entre los individuos no son resultado del azar. Se deben, principalmente a cierta orientación espontánea que no es producto de la reflexión y cuya intensidad difiere según la persona.

En los años sucesivos fueron apareciendo otras herramientas que nos estimulaban a continuar ahondando en esta investigación, hasta que se establecieron como eje vertebrador de nuestra metodología de proyecto: desde hace casi 30 años el Sistema de Diseño Humano ${ }^{84}$, y el eneagrama -una

\footnotetext{
81 "Entender toda inspiración presente en cada uno de los innumerables medios de expresión del Hombre, trabajar a partir de nuestras manos, nuestros ojos, pies, estómagos, a partir de la base de nuestros movimientos, y no basándose en normas estadísticas y reglas creadas según el principio de lo más usual; este es el camino hacia una arquitectura que sea tan variada como humana." PUENTE, Moisés. Jorn Utzon. Conversaciones y otros escritos. Barcelona: Gustavo Gili. 2010. Págs. 9 y 10.

${ }^{82}$ Según Jung: aunque todos disponemos de todas las posibilidades, las variaciones de la conducta son, sobre todo, la consecuencia de las preferencias espontáneas respecto a cuatro dimensiones fundamentales del psiquismo, cada una de las cuales está definida por dos polos opuestos que definen los extremos en cuanto a: la orientación de la energía, los modos de percepción, los criterios de decisión y el estilo de vida. Op. cit. Sé tú mismo... Pág. 13.

83 "El MBTI está estructurado sobre 4 dimensiones principales, cada una de las cuales está definida por dos polos opuestos:(...) De la combinación de estas ocho preferencias resultan 16 caracteres tipo". Op. Cit. Sé tú mismo... Pág. 143.

84 El Sistema de Diseño Humano, la Ciencia de la Diferenciación, es un nuevo sistema de autoconocimiento que sintetiza gráficamente aspectos de "los antiguos sistemas observacionales de la astrología, el I Ching chino, los chakras hindu-bramines y el Árbol de la Vida de la tradición zohar/cabalística; y las disciplinas
}

teoría caracterológica muy antigua que se ha transmitido hasta nuestros días por estricta tradición oral, introducida en occidente por G.I. Gurdjieff en la década de los 20 y más tarde adaptada por Oscar Ichazo y Claudio Naranjo en la década de los 70- nos plantean una serie de prácticas que tienen por objeto descifrar aquellas cartografías individuales que hasta la fecha pasaban inadvertidas. En ellas podemos encontrar un anclaje profundo como sustrato catalizador del proyecto arquitectónico: nos permiten diferenciar de un modo extraordinariamente preciso, lo esencial e ineludible, de lo arbitrario y circunstancial en cada ser humano.

Con lo expuesto antes, y desde la guía de las citadas herramientas, se ha puesto en marcha una metodología que podría definirse como arquitectura Humana ${ }^{85}$, colocando al verbo HABITAR en el lugar más alto del proceso creativo; un verbo que incluye y abraza la condición experiencial del ser humano; el habitante que piensa, que juega, que sueña, que crea e inventa lo cotidiano,... que disfruta de sentirse vivo y crece en sintonía con un entorno ${ }^{86}$ próximo, que finalmente lo escucha, lo respeta y lo protege ${ }^{87}$. La arquitectura Humana entrega al hombre concreto un medio donde finalmente se siente reconocido, potenciado; un ser decisivo e irremplazable.

contemporáneas de la mecánica cuántica, la astronomía, la genética y la bioquímica." BUNNELL, Linda / RA URU HU. Diseño Humano. El revolucionario sistema de autoconocimiento. Madrid: Gaia Ediciones. 2014. Pág 36.

${ }_{85}$ Arquitectura Humana es el nombre que lleva nuestro proyecto. Sus raíces emergen de tres ramas fundamentales del conocimiento: la psicología, la arquitectura y la educación, que confluyen con la finalidad de proporcionar herramientas para la evolución consciente del organismo humano como totalidad y parte de una totalidad mayor.

86 "Cuando cojo células sanas y las coloco en un entorno nocivo, las células enferman y mueren. Si un médico las mirara, diría: ¿Qué medicina hay que darles? ¡Pero no hace falta ninguna medicina! Les cambias el entorno nocivo, las colocas en uno sano y saludable y las células sanan. Esto demuestra una cosa muy sencilla: el destino de la célula refleja lo que está ocurriendo en el entorno." Fragmento de la entrevista al Dr. Bruce H. Lipton, biólogo celular.

Puede verse en: http://alsol.es/wpcontent/uploads/BRUCE-LIPTON.pdf

${ }^{87}$ Hacemos nuestras las palabras de Juhani Pallasmaa cuando escribe: "sigo creyendo en la viabilidad de una arquitectura de la reconciliación, una arquitectura que pueda mediar en dar la 'bienvenida' al hogar del ser humano. Todavía necesitamos casas que refuercen nuestro sentido de la realidad humana y de las jerarquías esenciales de la vida. El arte de la arquitectura todavía puede producir casas que nos permitan vivir con dignidad." Op. cit. Habitar... Págs. 39 y 40. 
De esta manera, la arquitectura no se propone ya como una herramienta puramente disciplinar o autorreferencial, sino como el receptáculo a través del cual ponemos a trabajar los mapas que se encaminan esencialmente a construir espacios, paisajes y escenarios donde las fuerzas humanas se enraízan y se propagan como directoras del proceso proyectual, haciendo de las cartografías del ser humano el material más apreciado de la acción arquitectónica ${ }^{88}$.

\section{APLICACIÓN O CASO DE ESTUDIO ${ }^{89}$}

"Nada es tan fácil de ver como la consciencia cuando reconocemos que está incorporada a las formas y las estructuras que creamos. ${ }^{100}$

\section{Miriam Simos}

Durante más de dos años, Roberto estuvo diseñando los espacios para satisfacer su necesidad de ocupar un entorno privado, en una porción de tierra con unas características específicas. Hizo uso de algunas herramientas informáticas gratuitas y se inspiró en las imágenes y los planos ofrecidos por las revistas de vanguardia y diversas publicaciones.

Al facilitarnos el material gráfico que había desarrollado con cuidadosa dedicación durante aquellos años, descubrimos a un ser encapsulado bajo capas y capas de razonamientos e imágenes de la moda doméstica difundidas por los medios de comunicación masiva. Para poder darnos cuenta de sus condicionamientos, fue crucial el estudio de sus invariantes vitales a través del Sistema de Diseño Humano -SDHGracias al análisis y la transmisión de su gráfico individual, la rigidez de sus planteamientos iniciales, basados en los

\footnotetext{
${ }^{88}$ Véase: Hacia un habitar arquitectónico

http://lasformasdelhabitar.blogspot.com.es/2014/04/camin ando-hacia-el-habitar_30.html

${ }^{89}$ El proyecto al que hacemos referencia en el caso de estudio que compartimos en este artículo fue visado por el Colegio de Arquitectos de Aragón en septiembre del 2014.

Autores de proyecto: Ignacio Abad Cayuela y Pedro Antonio Bel Anzué.

Colaboradores: Juan Moreno Ortolano (Licenciado en Historia del Arte e investigador), Nicolás Buendía Roca (Arquitecto), Patricia Abadías Monzón (Graduada en Ingeniería de la Edificación y Máster en Ecodiseño y Eficiencia Energética en la Edificación), María Paz Sáez Pérez (Arquitecta Técnica), Javier Muñoz Escolano y Sergio Calle Pérez (Diplomados en Arquitectura Técnica). 90 VENOLIA, Carol. Casas que curan. Ediciones Martínez Roca. 2012. Pág 40.
}

parámetros estandarizados que alimentan las inercias del statu quo, fueron dando paso a requerimientos más auténticos que nacían de la verificación empírica de su verdadera naturaleza como individuo diferenciado: el Ser Humano empezaba a sentirse comprendido y aceptado desde su unicidad.

Roberto se sentía plenamente reconocido. Las resonancias que la lectura de su Cuerpo Gráfico provocó en él, tuvieron consecuencias palpables: compartimos instantes de emocionalidad profunda. Estimulados por las premisas esenciales, comenzamos a articular la singularidad del emplazamiento con los demás factores de contorno: condicionantes climáticos, urbanísticos, económicos... Integró la esencia de las primeras propuestas y se vio a sí mismo habitando y creciendo en los espacios que habíamos representado en aquellos primeros planos: la especificidad de un diseño que emerge desde la verdadera naturaleza de un ser humano, revela formas de habitar que resuenan con la singularidad del individuo desde la que se está proyectando.

\section{UN DISEÑO PARA SU CO-RAZÓN}

Renunciamos a cualquier imagen preconcebida, sea abstracta o monolítica; a un urbanismo servil en la medida de lo posible, sobre todo el que nos aleja de la urbanidad. Nos apartamos de la idea de universalizar, del hombre tipo, del estilo de vida contemporáneo, de lo que está vacío de humanidad, de esencia humana o de sustancia.

Queríamos saber con qué disfrutaba Roberto y cómo experimentaba su cotidianeidad. Queríamos saber si ya era feliz. Necesitábamos descubrir quién era; si estaba satisfecho consigo mismo y cómo experimentaba el mundo alrededor; su propio mundo. Él era el centro de todas las propuestas que emergían. La idea germinal estaba enraizada en sus fuerzas vitales y el proyecto estaba dirigido a ofrecerle escenarios, recorridos y paisajes en consonancia con la vida que estaba creciendo desde sí mismo ${ }^{91}$.

\footnotetext{
91 "...se produce un estado más feliz si nos entregamos a lo que a veces se llama autorregulación organísmica, que es más o menos lo que los chinos Ilamaban el Tao: la Ley de la Naturaleza." NARANJO, Claudio. La revolución que esperábamos. Ediciones La Llave. 2013. Pág. 144.
} 
Figura 1. Imágenes de Roberto para su vivienda dibujadas por el mismo.

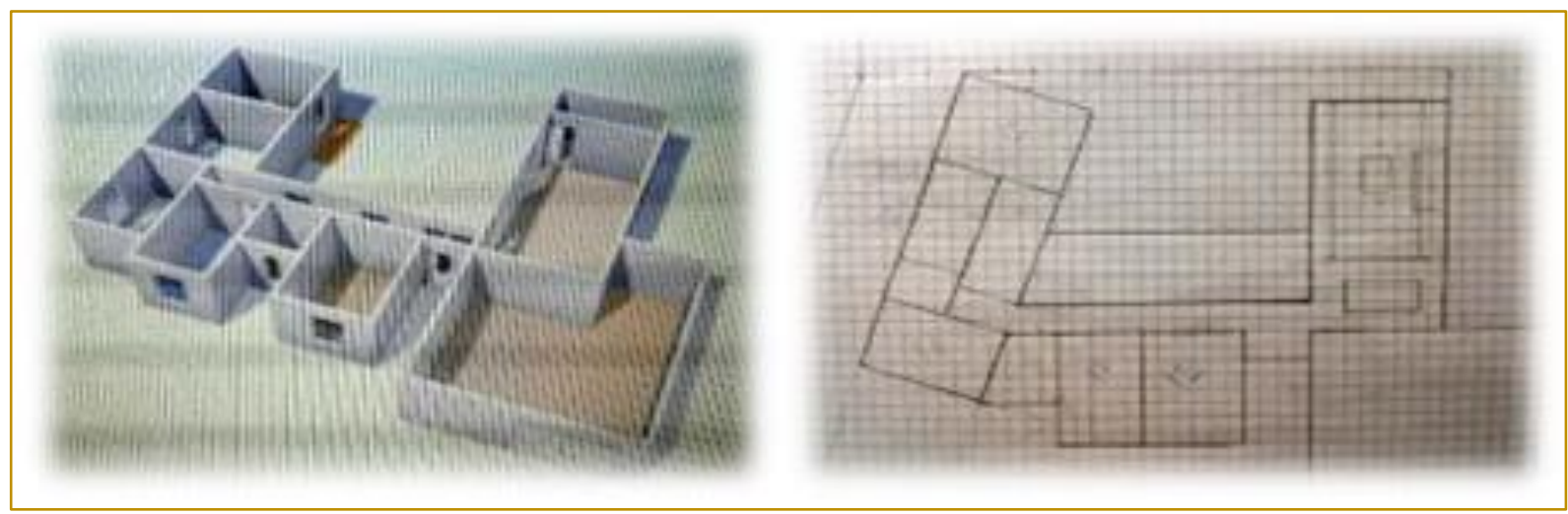

IMPLEMENTACIÓN DEL SDH EN EL PROYECTO

En este proyecto, el SDH nos facilitó el gráfico desde donde acceder a los estratos más profundos de la naturaleza de Roberto. Este mapa, además, nos permite deducir con gran precisión la estructura del carácter de cada individuo -su eneatipo- que habitualmente se erige como una fortaleza que tiende a limitar, de manera dramática, el ámbito de decisiones y experiencias de su portador. De esta manera, pudimos reconocer los vehículos desde donde se despliega el viaje de Roberto: el cuerpo físico, mental y emocional, así como la forma energética que nos revela las constantes vitales que lo impulsan desde su nacimiento y que van a acompañarle el resto de su vida. Estas fueron las fuerzas que colocamos en el lugar más elevado de nuestro proceso creativo y que, por lo tanto, activaron el marco vivencial y relacional del hábitat de Roberto.

Descubrimos su manera de establecer un estilo de vida a través del reconocimiento de la dualidad fundamental que existe en cada bioforma humana: "somos una consciencia binaria, una sintesis de una consciencia de la Personalidad y una consciencia del Diseño -la parte inconsciente de nuestra naturaleza esencial- $y$ en el perfil podemos comprender el quantum de las dos. ${ }^{102}$

Presentamos, en una breve síntesis, las principales tramas vitales extraídas del análisis del gráfico:

Proceso vital de tres fases para surgir como un Modelo de Conducta: El de Roberto, un perfil 6/2, nos revela una personalidad de línea 6 que viene a constituirse como ejemplo, y que pasará por tres fases significativas en su vida. De esta forma acontece el despliegue de su ser para ejercer un papel de liderazgo en su fase de madurez, y desde ahí mostrarnos cómo vivir conforme a nuestra propia autoridad. El ermitaño inconsciente de línea 2, dispone de un talento natural y quiere que le dejen en paz para centrarse en sus afanes. Su genialidad original debe ser protegida para permitir que se desarrolle naturalmente y puesta a disposición del mundo llegado el momento. No le vale cualquier cosa, y va a estar atento a una llamada específica y especial que le permitirá poner de manifiesto sus dones y encarnar su poder de modelo de conducta.

Catalizador de cambios: Su Canal de Apertura -22/12- junto con la Puerta de la Crisis -36- definen su naturaleza emocional, en el área derecha del gráfico, que nos revela las dinámicas de un ser social con una enorme capacidad para provocar cambios en la vida de otros individuos. Este potencial depende del grado de paciencia que cultive y la profundidad creativa de los sentimientos que se permita experimentar escuchando el paso de sus emociones.

\footnotetext{
${ }^{92}$ Op. Cit. Diseño Humano... Pág. 286.
} 
Figura 2. Cuerpo gráfico de Roberto y mapa de la personalidad.

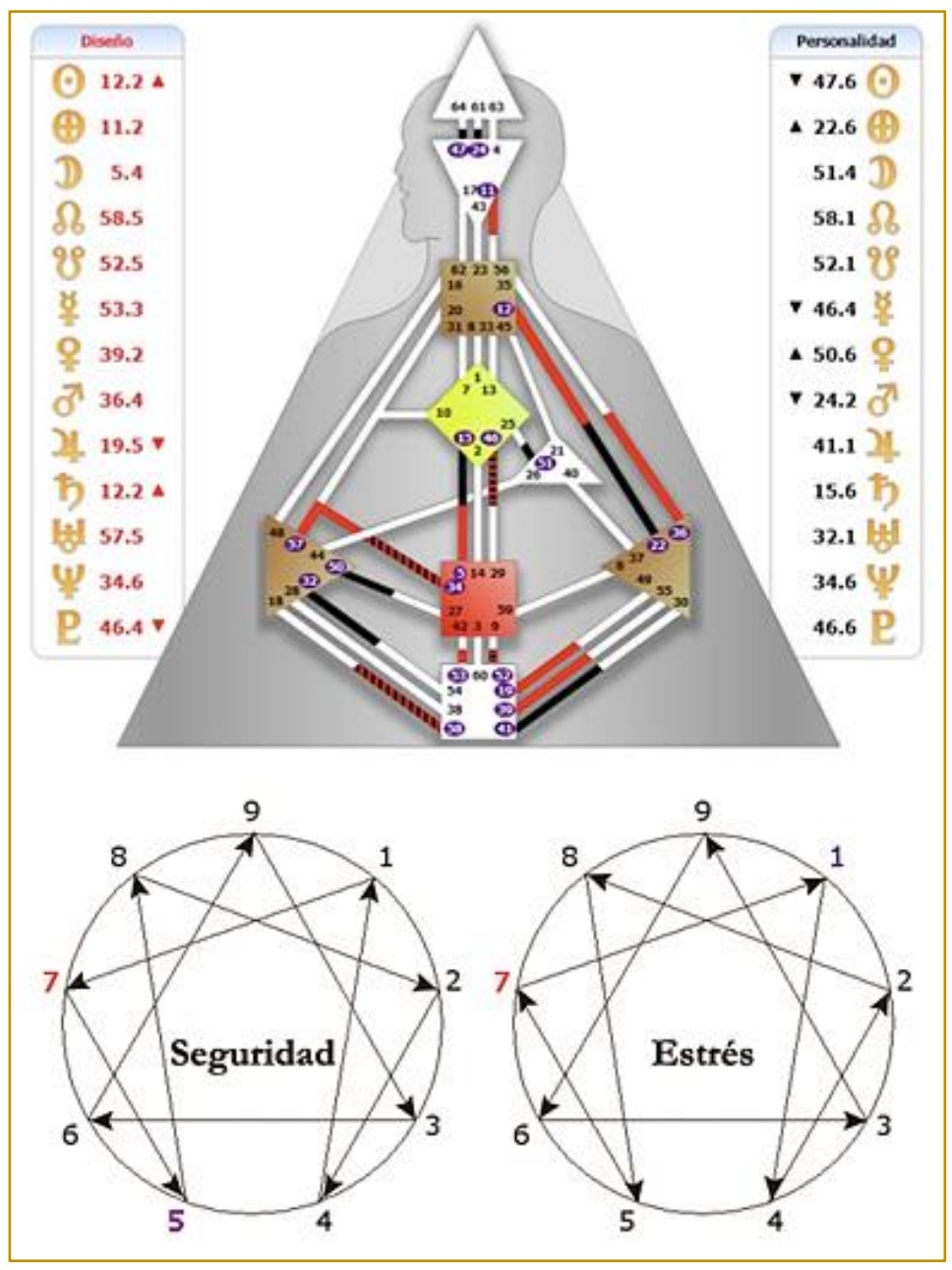

Respeto por sí mismo a través de la escucha de su propio cuerpo: sus Canales del Poder 34/57- y del Ritmo -5/15- en sincronía con las activaciones del bazo y el Monopolo Magnético ${ }^{93}$, definen su área instintiva. Es la parte de su ser que lo conecta con el instante vivencial, gracias a la que se siente seguro en su espontaneidad. Esta zona ocupa la parte izquierda del gráfico con el bazo; y los centros sacral y monopolo magnético ${ }^{94}$ coloreados en rojo y amarillo en zona central.

\footnotetext{
93 "establece nuestra identidad como una dirección a través del tiempo en el espacio, que llamamos nuestra geometría. Ahí es donde nuestro flujo de energía único (o definición) nos conecta con el flujo de toda la vida; o cómo estamos conectados con el universo. El Monopolo Magnético nos va trayendo nuestra vida." Op. Cit. Diseño Humano... Pág. 68.

94 "Los nueve centros son núcleos de energía que transforman o transmutan la fuerza vital según fluye por el Cuerpo Gráfico." Op. Cit. Diseño Humano... Pág. 66.
}

Descubrimos que es de enorme importancia para él estar conectado con su flujo existencial a través de su respuesta interna. Sólo de esta manera todo lo que haga le va a resultar propicio y natural, y así podrá beneficiar sutilmente a quienes le rodean, conduciéndoles a su propio ritmo y sentido del tiempo.

Dilema interno primordial: dada su naturaleza -que se deja ver en estas dos definiciones separadas- nos damos cuenta del reto que supone para Roberto afirmarse en su esencia. Con la mente, el corazón y los centros de presión sin definir, el enorme potencial de sabiduría que deja abierto su diseño puede haberse transformado en una férrea fijación mental, al haber experimentado su indefinición desde la carencia y no como una gran apertura a la diversidad y el tremendo potencial de enriquecimiento que supone esta configuración. La buena noticia es que sólo necesitará integrar dos claves para comenzar 
a experimentar su diferenciación; el camino hacia su autenticidad. En su nueva casa, cimentada sobre estas premisas, se sentirá por fin en un entorno que lo comprende y lo protege, donde la expansión de su potencialidad no va a encontrar resistencias para que sus fuerzas vitales le permitan habitar el mundo plenamente.

\section{DE LA ENERGÍA A LA MATERIA}

A través del proyecto, los mapas de lo invisible se fueron transmutando en una realidad más densa; las dinámicas internas del habitante fueron confrontadas con el suelo, los materiales y los climas. Se nos revelaban confluencias; la forma emergía de esta simbiosis sin apenas resistencias.

De esta manera, las fuerzas vitales que dinamizaban este profundo deseo de habitar, generaban las pautas sobre las que se constituyó el esqueleto material de su vivienda.

Figura 3. Gestación del edificio utilizando las herramientas de autoconocimiento

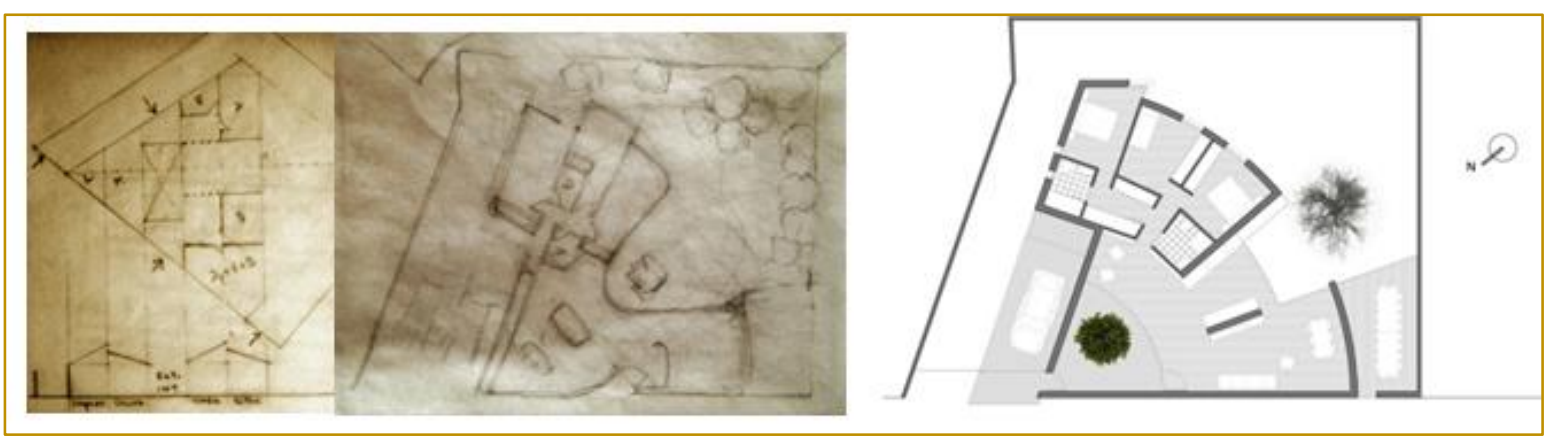

Finalmente señalamos los aspectos más destacados que, desde el diseño, acompañan la naturaleza esencial de Roberto:

Ambivalencia: el habitante ermitaño y enormemente social, dependiendo de sus estados de ánimo, se siente protegido, en su casa, de un entorno sin aparente urbanidad. Se origina una vivienda que emerge desde su condición maciza frente las orientaciones norte y oeste con muros ciegos de gran espesor para combatir la contaminación acústica, proteger del fuerte viento dominante "el cierzo" y preservar la privacidad.

Figura 4. Vista aérea.

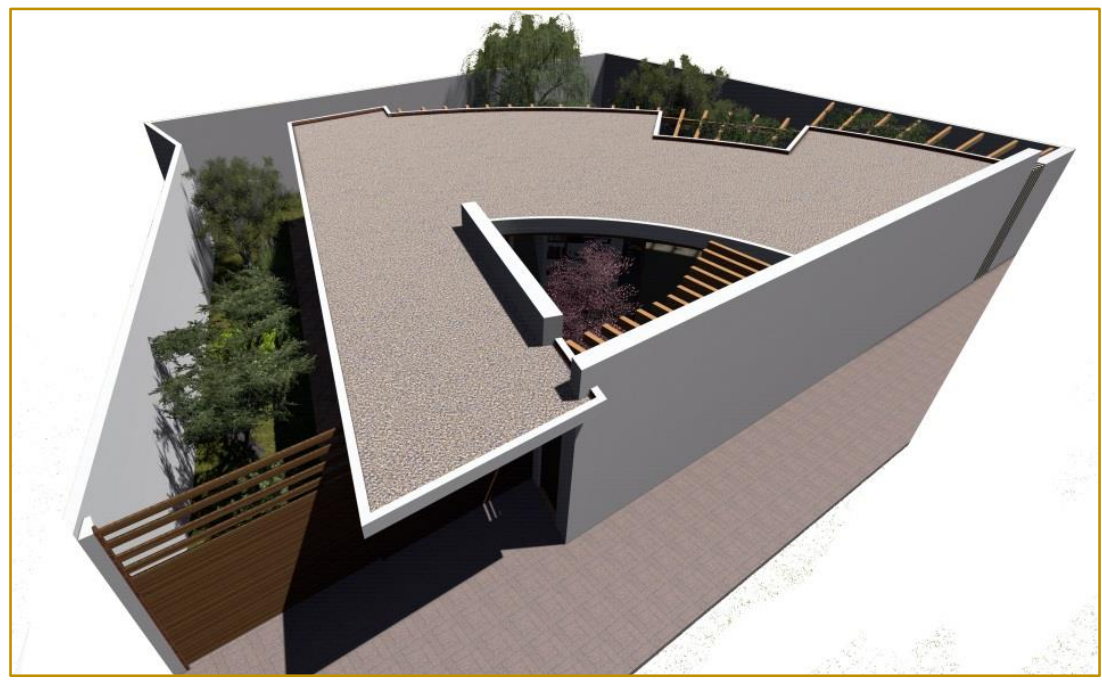

Fuente: Nicolás Buendía Roca 
Una vez cruzamos el primer umbral; el patio interior de acceso, entramos al espacio de mayor amplitud de la vivienda. Un espacio idóneo para socializar a través del que los espacios exteriores a ambos lados pueden conectarse generando una expansión mayor.
La condición de intimidad se va acentuando gradualmente a medida que nos acercamos hacia la zona este, de descanso, pudiendo establecer barreras temporales mediante grandes puertas correderas que se ocultan en el espesor de las particiones.
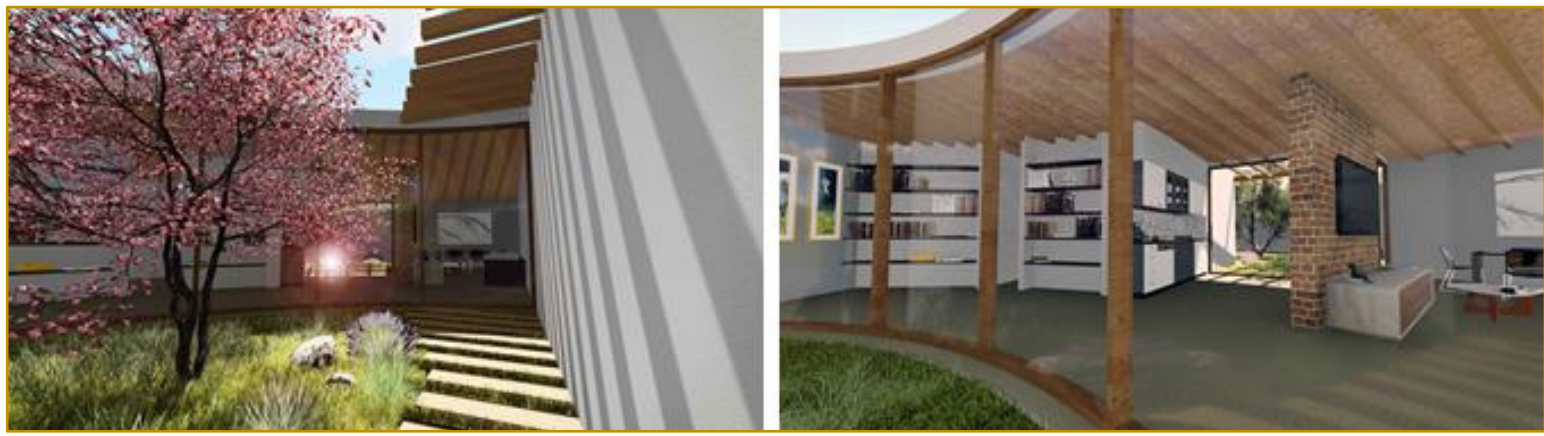

Figura 5. Desde el acceso, la vivienda se muestra, se hace porosa, ofrece escenarios. Fuente: Nicolás Buendía Roca

- Vinculación con el flujo natural de la vida: la creación de pautas espaciales y de atmósferas que lo conectarán con el presente y favorecerán la sincronización de sus propios ritmos con los ciclos de la naturaleza. Conseguimos que todas las estancias queden orientadas hacia el sur mediante una disposición radial que al mismo tiempo permite una secuencia espacial de espacios intermedios o umbrales. De esta manera se intensifica la relación directa con el paisaje natural, con las estaciones y los ciclos solares; con la vida: la luz, la tierra, el aire, el agua y la sombra matizada por los árboles que constituyen una segunda protección. Esta atmósfera que desdibuja los límites interiorexterior, potencia la conexión del habitante con los estratos más profundos, más íntimos y casi abandonados de su naturaleza. Las aperturas hacia el sur, nos permiten aprovechar la energía pasiva del sol: en verano, las hojas de parra protegen el vidrio de la radiación solar directa, y al desprenderse, llegado el invierno, permiten el paso de los rayos solares hasta el interior de la vivienda. La leve inclinación de la parcela favorece las vistas a las colinas cercanas.
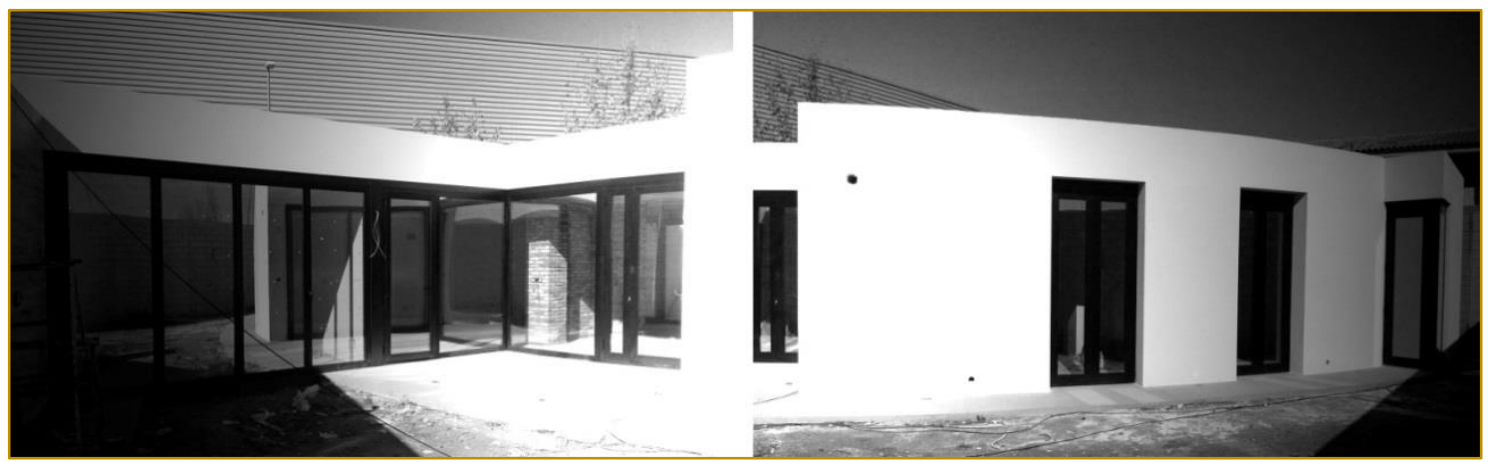

Figura 6. Fachada interior -sur-. En construcción.

Roberto se encuentra en la segunda fase de su vida, a la que ingresó entre los 29 y 30 años. Se siente cómodo en la retirada, donde poder descubrir lo que es fiable y funciona en el mundo. Empieza a ser considerado por su saber. Roberto es un gran lector, que necesita ver los libros para sentirse atraído por ellos.
La zona más próxima a los dormitorios, vinculada al patio del almendro autóctono, toma la luz del norte, evitando reflejos o sombras. Se trata, sin duda, de la atmósfera más apropiada para acomodar su rincón de lectura. Este espacio que comunica las estancias más íntimas de la casa con la parte 
más abierta y luminosa; será recorrido con frecuencia a lo largo del día. La presencia de los libros, va a ser una constate que envuelva al habitante en un escenario propicio para sentirse seducido e invitado a saborear el placer de la lectura de manera espontánea. Sus hijos crecerán en un paisaje que los acompañará a integrar el hábito de aprender leyendo, de manera casi natural desde sus primeros pasos. Parece fácil imaginar momentos mágicos compartidos en familia propiciados por la cercanía de los cuentos infantiles.

- En esta fase, se encuentra en el momento de crear familia, de expandirse. Las estancias han sido dimensionadas para que puedan ser dobles o individuales, por lo que posibilitan distintas opciones de ocupación que permitan adaptarse a la futura familia. Mientras llegan los niños, quedarán disponibles para amigos, familiares o invitados.

- Su proceso de maduración natural, pausado, en tres fases, entra en sintonía y sincronía con la elección de materiales nobles, que envejecen bien con el paso del tiempo. La vivienda se ha pensado utilizando una paleta reducida de materiales tradicionales como la madera natural y la piedra que acentúan y orquestan el acompañamiento de los ciclos naturales con el ciclo global de duración de su propia vida.

Figura 7. Fachada exterior -oeste-. En construcción.

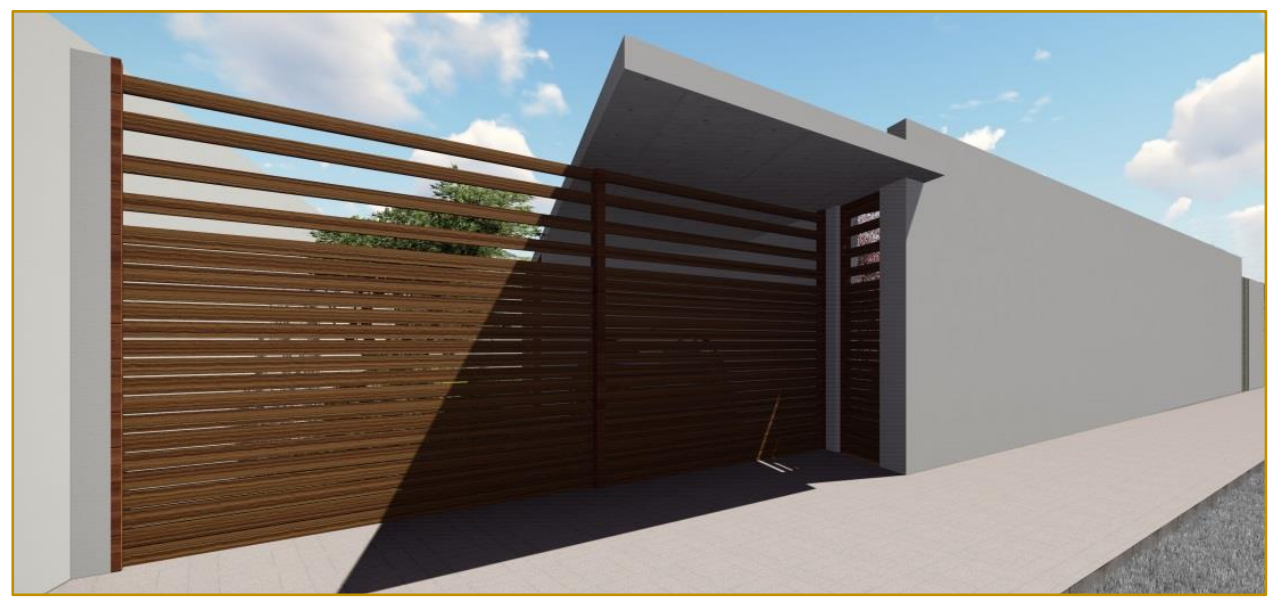

Fuente: Nicolás Buendía Roca

En líneas generales, acabamos de exponer las directrices organizativas del proceso de investigación que estamos llevando a cabo en nuestro estudio durante años, dejando ver la clara intención de defender al Hombre a través de la arquitectura, en su condición incuestionable de ser absolutamente único y al mismo tiempo proyectado irremisiblemente a confrontar su unicidad -a través de su propia experiencia y autoexpresión- con el resto de seres humanos que cohabitan en el

\section{REFERÊNCIAS}

[1] ÁBALOS, Iñaki (2000). La buena vida. Visita guiada a las casas de la modernidad. Barcelona: Gustavo Gili.

[2] ALMAAS, A.H. (2002). Facetas de la Unidad. Barcelona: La Liebre de Marzo. mismo planeta que él. En este caso, la acción arquitectónica se revela como una extensión de las energías primigenias de cada ser humano, encauzadas mediante la aplicación de las cartografías mencionadas a través de un proyecto que ofrece entornos de libertad y protección, y favorece un despliegue vital en consonancia con la verdadera naturaleza de quien está dispuesto a reconocerse, a habitarse y a permitirse un viaje en conexión con su propia esencia.

[3] BACHELARD, Gaston (1965). La poética del espacio. México: Fondo de Cultura Económica.

[4] BUNNELL, Linda / RA URU HU (2014). Diseño Humano. El revolucionario sistema de autoconocimiento. Madrid: Gaia Ediciones. 
[5] CHAVES, Norberto (2005). El diseño invisible. Siete lecciones sobre la intervención culta en el hábitat humano. Buenos Aires: Paidós.

[6] FERNÁNDEZ COX, Cristián (2005). El orden complejo en la arquitectura. Teoría básica del proceso proyectual. Santiago de Chile: Ediciones Universidad Mayor.

[7] CAUVIN, Pierre / CAILLOUX, Geneviève (1997) Sé tú mismo. De la tipología de Jung al MBTI. Bilbao: Ediciones Mensajero.

[8] LE CORBUSIER (1998). Hacia una arquitectura. Barcelona: Apóstrofe.

[9] LLORENS, Antoni. (2016). La estructura de la nada. Una raíz común entre el eneagrama y el árbol de la vida. Barcelona: Ediciones La Llave.

[10] NARANJO, Claudio (2013). La revolución que esperábamos. Barcelona: Ediciones La Llave.

[11] GEBSER, Jean (2011). Origen y presente. Girona: Atalanta.

[12] JUNG, C. G. (1997). El hombre y sus símbolos. Barcelona: Luis de Caralt Editor.

[13] PALLASMAA, Juhani (2006). Los ojos de la piel. Barcelona: Gustavo Gili.
[14] PALLASMAA, Juhani (2015). Una arquitectura de la humildad. Barcelona: Fundación Caja de Arquitectos.

[15] PALLASMAA, Juhani (2012). La mano que piensa. Sabiduría existencial y corporal en la arquitectura. Barcelona: Gustavo Gili.

[16] PALLASMAA, Juhani (2016). Habitar. Barcelona: Gustavo Gili.

[17] PUENTE, Moisés (2010). Jorn Utzon. Conversaciones y otros escritos. Barcelona: Gustavo Gili.

[18] SERRA, Rafael (2009) Arquitectura y climas. Barcelona: Gustavo Gili.

[19] VENOLIA, Carol (1995). Casas que curan. Ediciones Martínez Roca.

[20] WILBER, Ken (2012). La conciencia sin fronteras. Barcelona: Kairós.

[21] WILBER, Ken (2001). Una teoría de todo. Barcelona: Kairós. 


$$
\text { Alutary }
$$




\section{FABIANE DOS SANTOS TOLEDO (Organizadora)}

Mestre em geografia pela Universidade Federal de Uberlândia, na área de planejamento ambiental, atuante em geociências, com ênfase em ambiental - áreas verdes, índice de áreas verdes, espaços públicos livres e parques urbanos. Possui graduação em Geografia (Licenciatura e Bacharelado) pela Universidade Federal de Uberlândia, mestrado em geografia pela Universidade Federal de Uberlândia. Tem experiência na área de Geociências, com ênfase em Geografia ambiental, atuando principalmente nos seguintes temas: áreas verdes, índice de áreas verdes, espaços públicos livres e parques urbanos.

\section{ANA CLÁUDIA ROCHA CAVALCANTI}

Possui graduação em Arquitetura e Urbanismo pela Universidade Federal de Pernambuco (1990), mestrado em Prática do Desenvolvimento - Oxford Brookes University (1998) e doutorado em Desenvolvimento Urbano pela Universidade Federal de Pernambuco (2008). Pós- Doutorado na Facultad de Ciencias Sociales na Universidad de Buenos Aires (2014). Atualmente é professora associada 1 da Universidade Federal de Pernambuco. Professora permanente do Programa de Pós-Graduação em Direitos Humanos PPGDH-UFPE.

\section{ANDRÉ LUIZ BEZERRA DA SILVA}

Graduado em geografia, com mestrado e doutorado em geografia humana. Também fez doutoramento em planejamento urbano e regional. Realizou estágio pós-doutoral na Universidade Federal do Rio de Janeiro. Atua principalmente na área de geografia humana, estudando temas como mobilidade, transportes e equidade social. É professor de geografia no Departamento de Educação do Instituto Benjamin Constant - Rio de Janeiro - Brasil, atuando no ensino básico, técnico e tecnológico e na produção de material didático especializado para o ensino de geografia. É pesquisador associado do Laboratório Redes Urbanas do Instituto de Pesquisa e Planejamento Urbano e Regional da Universidade Federal do Rio de Janeiro (IPPUR-UFRJ), onde realiza estudos sobre transportes, mobilidade e equidade social. Também é membro integrado do Centro de Estudos de Geografia e Ordenamento do Território da Universidade do Porto (CEGOT-UPORTO), onde estuda questões ligadas à mobilidade e equidade social. É membro do Comitê Editorial e revisor da Revista Chão Urbano, do IPPUR-UFRJ.

\section{ANNA PAULA SCHERER LINO}

Graduada no bacharelado e licenciatura pela Universidade Federal do Paraná e professora da rede básica.

\section{ANTONIO JOSÉ DE ARAÚJO FERREIRA}

Antonio José de Araújo Ferreira é Bacharel em Geografia e Especialista em Planejamento Ambiental/UFMA, Mestre e Doutor em Geografia Humana/USP. É Professor Associado II do Departamento de Geociências/UFMA, assim com é vinculado aos programas de pósgraduação em Desenvolvimento Socioespacial e Regional (PPDSR) e de Geografia, Natureza e Dinâmica do Espaço (PPGeo) da Universidade Estadual do Maranhão.

\section{BRENO FONSECA DE ARAÚJO}

Arquiteto e Urbanista pela Pontifícia Universidade Católica de Minas Gerais, com experiência em práticas de extensão de assessoria técnica a ocupações urbanas na Região Metropolitana de Belo Horizonte, e processo de regularização fundiária, ambos coordenados pelo Escritório de Integração do Instituto de Ciências Sociais da PUC Minas. Coautor em pesquisa científica "Urbanização e Desastre: o caso de reassentamento de Paracatu de Baixo, Mariana, Minas Gerais", pelo Programa de Bolsa de Iniciação Científica (PROBIC Edital №082/2016). 


\section{CAROLINE CRISTIANE ROCHA}

Graduanda em arquitetura e urbanismo pela Pontifícia Universidade Católica de Minas Gerais. Interesse em pesquisa sobre os impactos da metropolização em territórios rurais, e as resistências do rural no urbano. Experiência em assessoria técnica direta à ocupações urbanas por meio de projetos de extensão (2015-2017). Bolsista de iniciação científica com projeto sobre urbanização de favelas (2018).

\section{CELENE CUNHA MONTEIRO ANTUNES BARREIRA}

Prof ${ }^{\mathrm{a}} \mathrm{Dr}^{\mathrm{a}}$ do Programa de Graduação e Pós-graduarão em Geografia do Instituto de Estudos Socioambientais da Universidade Federal de Goiás

\section{CÉLIO QUINTANILHA}

Graduado em Geografia pela Universidade Federal Fluminense (UFF), com licenciatura concluída em 2016 e graduando no curso de Bacharel em Geografia. Pós-Graduando no curso de Especialização no Ensino de Geografia pela Universidade Estadual do Rio de Janeiro (UERJ). Professor da rede privada de ensino.

\section{CRISTIANE ALCÂNTARA DE JESUS SANTOS}

Doutora em Geografía, Planificación Territorial y Gestión Ambiental pela Universitat de Barcelona (Espanha). Mestre em Geografia pela Universidade Federal de Sergipe. Licenciada e Bacharel em Geografia pela Universidade Federal de Sergipe. Professora Adjunta do Curso de Bacharelado em Turismo da Universidade Federal de Sergipe.

\section{DALVA MARÇAL MESQUITA SOARES}

Aluna do curso do Programa de Pós-graduação do Instituto de Estudos Socioambientais IESA da Universidade Federal de Goiás - UFG. Área de Concentração: Natureza e Produção do Espaço.

\section{FELIPE NASCIMENTO}

Graduado em Geografia pela Universidade Federal Fluminense (UFF), com licenciatura concluída em 2016 e graduando no curso de Bacharel em Geografia. Professor da rede privada de ensino.

\section{FLÁVIO ANTÔNIO MIRANDA DE SOUZA}

Professor Titular do Departamento de Expressão Gráfica e Professor permanente do Programa de Pós-graduação em Desenvolvimento Urbano (MDU) da Universidade Federal de Pernambuco. É pesquisador e vice-coordenador do Grupo de Pesquisa Observatório Pernambuco de Políticas Públicas e Práticas Sócio-Ambientais da UFPE.

\section{GABRIELA MARA BATISTA DE SOUSA}

Arquiteta Urbanista pela Pontifícia Universidade Católica de Minas Gerais, cursando a pósgraduação "Arquitetura Bioclimática: desempenho ambiental da edificação". Possui experiência em assessoria técnica a ocupações urbanas, com a participação no projeto de extensão "Assessoria Técnica às Ocupações Urbanas: superestruturas autoproduzidas", coordenado pelo Escritório de Integração do Instituto de Ciências Sociais da PUC Minas, além da coautoria em pesquisa científica "Urbanização e Desastre: o caso de reassentamento de Paracatu de Baixo, Mariana, Minas Gerais", pelo Programa de Bolsa de Iniciação Científica (PROBIC Edital №082/2016). 


\section{IGNACIO ABAD CAYUELA}

Arquitecto por la Escuela Superior de Arquitectura de Sevilla. Máster de la Construcción. Especialista en Sistema de Diseño Humano aplicado a la arquitectura. Ha participado como profesor invitado en la Universidad de Murcia y ha sido conferenciante en diferentes foros. Su trayectoria profesional se mueve en torno a su estudio propio (AMo_arquitectura y Arquitectura Humana). Su trabajo también ha incurrido en publicaciones en libros, revistas y congresos, tanto nacionales como internacionales. Dentro de su trayectoria destacan los premios recibidos en el Festival de Cartagena "Mucho Más Mayo", en el Concurso para el Edificio de Laboratorios Docentes y de Investigación "ELDI", conjuntamente con José Manuel Chacón, el Concurso para la Rehabilitación y adaptación del antiguo Cuartel de Instrucción de Marinería de Cartagena que fue premiado en la XVI Edición de los Premios de Arquitectura de la Región de Murcia y con el Premio Internacional Archizinc Trophee y, fundamentalmente, el premio de Construcción Sostenible 2018 (Ámbito Resto de España, Categoría Vivienda Unifamiliar).

\section{JOÃO GABRIEL DA SILVA OLIVEIRA}

João Gabriel da Silva Oliveira, aluno do curso de licenciatura em Geografia pela Universidade Federal do Maranhão. Foi bolsista PIBIC/UFMA nas cotas 2016/2017 (FAPEMA) e 2017/2018 (CNPq), com área de estudo voltada para o desenvolvimento socioeconômico do estado do Maranhão por meio da expansão da agroindústria.

\section{JOSÉ GERALDO PIMENTEL NETO}

É bacharel (2006), licenciado (2009) em geografia, mestre em Geografia (2008) e Doutor, com doutoramento sanduíche na Universidade de Buenos Aires (2014), em Desenvolvimento Urbano (2017) todos os títulos obtidos na Universidade Federal de Pernambuco (UFPE). Atualmente é pesquisador do Grupo de Pesquisa Observatório Pernambuco de Políticas Públicas e Práticas Sócio-Ambientais da UFPE atuando nas áreas dos regimes urbanos, geografia humana \& organização do espaço e políticas públicas urbanas e está desenvolvendo pós-doutoramento pelo Programa de Pós-Graduação em Desenvolvimento Urbano da UFPE.

\section{JUAN MORENO ORTOLANO}

Es profesor en el Departamento de Ingeniería e Investigaciones Tecnológicas -Carrera de Arquitectura- de la UNLaM (Buenos Aires). Licenciado en Historia del Arte y Máster en Historia de la Arquitectura. Becario FPU del Ministerio de Educación y Ciencia de España, Becario Fundación Caja Murcia. Ha sido profesor en la Universidad de Murcia -Departamento de Historia del Arte- y Personal Docente e Investigador en la Universidad de Alicante Departamento Expresión Gráfica, Composición y Proyectos-. Ha sido profesor invitado en las Facultades de Arquitectura de Plymouth y Buenos Aires (FADU). Ha realizado estancias de investigación en las Facultades de Arquitectura de Cartagena, Madrid, Barcelona, Buenos Aires, Nápoles y Lima. Participa y publica en diferentes congresos, revistas y libros nacionales e internacionales, y desempeña funciones activamente en Estudios de Arquitectura (AMo_arquitectura y Arquitectura Humana).

\section{KAUÊ AVANZI}

Mestre em Geografia Humana pela FFLCH-USP, educador no Ensino Básico, poeta e músico. Gosta de escrever, se divertir e confraternizar. 


\section{KEILHA CORREIA DA SILVEIRA}

Bacharel em geografia (2006), licenciada em geografia (2013), mestra em geografia (2010) e doutora em Geografia (2018), todos as formações desenvolvidas na UFPE. Trabalhou como professor substituta na Graduação do curso Licenciatura em Geografia e curso de Turismo ambos da UFPE. Atualmente é professora da Faculdade de Ciências Humanas de Igarassu (FACIG).

\section{LARISSA PRADO RODRIGUES}

Bacharelanda em Turismo pela Universidade Federal de Sergipe. Membro do Grupo de Pesquisa Gestão de Turismo e Hospitalidade.

\section{LUCAS MAIA}

Graduado em Geografia pela Universidade Federal Fluminense (UFF), com licenciatura concluída em 2016. Pós-Graduando no curso de Mestrado em Geografia pela Universidade Federal Fluminense (UFF).

\section{LÚCIA KARINE ALMEIDA}

Graduação em Arquitetura e Urbanismo pela Pontifícia Universidade Católica de Minas Gerais (2003), Especialização em Urbanismo pelo Instituo Metodista Izabela Hendrix (2005) e mestrado em Arquitetura e Urbanismo pela Universidade Federal de Minas Gerais (2009). Professora Assistente I do Curso de Arquitetura e Urbanismo da Pontifícia Universidade Católica de Minas Gerais, desde 2012, arquiteta e urbanista efetiva da Prefeitura Municipal de Belo Horizonte, na Secretaria Municipal Adjunta de Planejamento Urbano. Experiência em planejamento urbano e regional, licenciamentos de empreendimentos de impacto urbanístico e ambiental, parcelamento do solo, desenho urbano, planos de inventário de bens culturais municipais e arquitetura.

\section{PAULA PIRES SANTOS PEREIRA THOMAZ}

Arquiteta e urbanista pela PUC-Minas, possui experiência com projetos de extensão, assessoria técnica a grupos marginalizados, técnicas alternativas de urbanização, estudos da paisagem e história urbana.

\section{PIERO CARAPIÁ LIMA BAPTISTA}

Graduado em Desenho Industrial pela UNEB (2009) e graduado em Arquitetura e Urbanismo pela UFBA (2011). Mestre em arquitetura e urbanismo pelo PPGAU/UFBA (2014). Lecionou arquitetura e urbanismo no Centro Universitário Jorge Amado, e atualmente é doutorando no programa de Doutorado em Arquitetura e Urbanismo no PPGAU/UFBA, desde 2016. Atuou como pesquisador no Observatório da Copa - Salvador 2014 (PPGAU/UFBA), e hoje faz parte do grupo de pesquisa OBSERVA CAS (PPGAU/UFBA) e como investigador no grupo Diálogos Metropolitanos - Lima/Salvador (FAUFBA e PUC - Perú). Principais temas de pesquisa: megaeventos, Operações Urbanas Consorciadas, Planejamento Estratégico Urbano, urbanismo e políticas públicas para os centros antigos.

\section{PRISCILA MARIA DE FREITAS}

Doutoranda em Planejamento Urbano e Regional e Mestrado na mesma área, com Pós em Gestão de Cidades, Pós em Docência no Ensino Superior e Pós em Crescimento Urbano Sustentável, Formada em Arquitetura em Urbanismo. Profissional com mais de 10 anos de experiência, já atuou como autônoma, em escritório de arquitetura e engenharia civil, elaborando estudos de viabilidades de projetos, suporte técnico e participação na produção de material técnico de Projeto Executivo. Servidora municipal na Prefeitura de Jacareí desde 
2011, atuando em áreas de planejamento estratégico, fazendo parte da Comissão de Alteração do Plano Diretor de Jacareí, em 2012. Atuou como coordenadora dos cursos de arquitetura e urbanismo e de engenharia civil da Faculdade Anhanguera de Jacareí; e, desde 2015 atua como docente nessa instituição. Autora do livro "Direito à Cidade Sustentável" e de diversos artigos científicos na área de arquitetura, educação no ensino superior, direito urbanístico e planejamento urbano e regional.

\section{VALTER LUIZ DE MACEDO}

Geógrafo, mestre e doutor em Planejamento Urbano e Regional pela Universidade Federal do Rio de Janeiro (UFRJ), professor do Instituto de Geografia da Universidade do Estado do Rio de Janeiro (UERJ) e do Colégio Brigadeiro Newton Braga (III COMAER). Desenvolve pesquisa sobre a gênese e estruturação do espaço fluminense junto ao Grupo de Estudos do Território e de História Urbana (GESTHU/IPPUR/UFRJ) e ao Grupo de Trabalho "Políticas Públicas e Territórios" (CLACSO, Conselho Latino-americano de Ciências Sociais). 


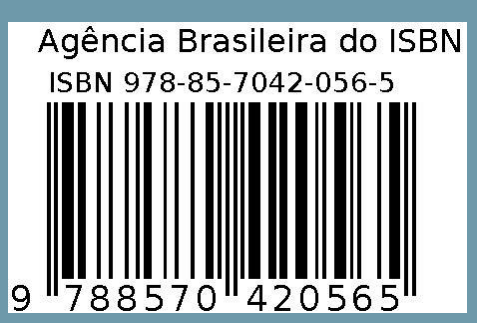

